\title{
Visualidade do livro didático no Brasil: \\ o design de capas e sua renovação nas décadas de 1970 e 1980
}

DIDIER DOMINIQUE CERQUEIRA DIAS DE MORAES

DISSERTAÇÃO APRESENTADA À FACULDADE DE EDUCAÇÃO

DA UNIVERSIDADE DE SÃO PAULO PARA A OBTENÇÃO DO TÍTULO DE MESTRE

LINHA DE PESQUISA LINGUAGEM E EDUCAÇÃO

ORIENTADOR PROF. DR. NILSON JOSÉ MACHADO

SÃO PAULO, 2010 
AUTORIZO A REPRODUÇÃO E DIVULGAÇÃO TOTAL OU PARCIAL DESTE TRABALHO, POR QUALQUER MEIO CONVENCIONAL OU ELETRÔNICO, PARA FINS DE ESTUDO E PESQUISA, DESDE QUE CITADA A FONTE.

\section{Catalogação na Publicação Serviço de Biblioteca e Documentação \\ Faculdade de Educação da Universidade de São Paulo}

371.34 Moraes, Didier Dominque Cerqueira Dias de

M827v Visualidade do livro didático no Brasil: o design de capas e sua renovação nas décadas de 1970 e 1980 / Didier Dominique Cerqueira Dias de Moraes; orientação Nilson José Machado. São Paulo: s.n., 2010. 182 p.; il.; graf.

Dissertação (Mestrado - Programa de Pós-Graduação em Educação. Área de Concentração: Linguagem e Educação) - - Faculdade de Educação da Universidade de São Paulo.

1. Livros didáticos 2. Visualidade 3. História editorial 4. Design gráfico 5. História do design gráfico (Brasil) I. Machado, Nilson José, orient. 
FOLHA DE APROVAÇÃO

Didier Dominique Cerqueira Dias de Moraes

Visualidade do livro didático no Brasil: o design de capas e sua renovação nas décadas de 1970 e 1980

Dissertação apresentada à Faculdade de Educação

da Universidade de São Paulo para a obtenção do título de Mestre

Linha de pesquisa: Linguagem e Educação

Aprovado em

BANCA EXAMINADORA

PROF. DR.

INSTITUIÇÃO

ASSINATURA

PROF. DR.

INSTITUIÇÃO

ASSINATURA

PROF. DR.

INSTITUIÇÃO

ASSINATURA 



\section{AGRADECIMENTOS}

Em primeiro lugar, ao Prof. Dr. Nilson José Machado, pelo estímulo inicial que se transformou em acolhida ao projeto e orientação precisa e cuidadosa durante todo o mestrado, pesquisa e redação da dissertação.

Ao Prof. Dr. Celso Fernando Favaretto, da Faculdade de Educação da USP, e ao Prof. Dr. Marcos da Costa Braga, da Faculdade de Arquitetura e Urbanismo da USP, pela leitura atenta, críticas e indicações feitas no processo de qualificação, fundamentais para a configuração final da dissertação - mas não obviamente por suas falhas -, como também pela orientação fornecida em suas disciplinas para que os trabalhos finais alimentassem a dissertação.

À Prof.a Dr.a Rosa lavelberg e à Prof.a Dr. a Sonia Castelar, da Faculdade de Educação, e

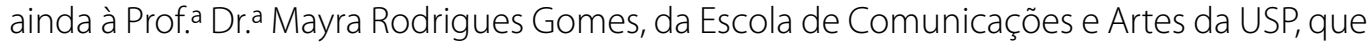
ministraram disciplinas e conduziram os trabalhos finais no mesmo sentido.

Ao Prof. Dr. Francisco Inácio Homem de Melo, da Faculdade de Arquitetura e Urbanismo da USP, pelo incentivo primeiro e proposição do tema, bem como por sugestões bibliográficas e imagéticas e comentários decisivos em vários momentos.

Aos designers Ary Almeida Normanha e Mário Sílvio Cafiero, pelos longos e detalhados depoimentos e pela cessão de várias das imagens aqui reproduzidas. A Irami Bezerra da Silva, Carmem Lúcia Campos, João Guizzo e Jiro Takahashi, pelas informações fornecidas em depoimentos ou conversas. Ao professor e designer Sylvio Ulhoa Cintra Filho por informações e indicações bibliográficas.

Às bibliotecárias Ivinin Varela e Roseane Paula Moreira, da Abril Educação, que facilitaram o acesso à Memória da Editora Ática e a documentação iconográfica realizada. A Tânia Silva, bibliotecária do IBEP, que propiciou a consulta ao acervo da Companhia Editora Nacional. A Walber Lustosa, Ivani Bastos e Vanessa Umbelina, bibliotecários da FEUSP, que facilitaram a pesquisa e a documentação fotográfica na Biblioteca do Livro Didático.

À Prof.a Dr.a Marcia de Paula Razzini e à Prof.a Dr.a Maria Rita Toledo, da Pontifícia Universidade Católica de São Paulo; à Prof. ${ }^{a}$ Dr. ${ }^{a}$ Samira Youssef Campedelli e à Prof. ${ }^{\text {D Dr. }}$ a Maria Aparecida Baccega, da Escola de Comunicações e Artes da USP; a Luiz Tonolli e Carlos Mendes Rosa, da Editora Ática; a Fernanda Costa da Silva, da Abril Educação; aos professores Valdemar Vello, Francisco Platão Saviolli, Francisco Marto de Moura, Avelino Antonio Correa e Amadeu Marques; a Cíntia Trigo, Vera Saviolli e Síntia Mattar - a todos pela inestimável colaboração.

Aos designers Marcello Araujo e Sara Goldchmit pela cessão de imagens para reprodução, mas também pelas discussões sobre design suscitadas pelo trabalho com livro didático. Aos designers Eliana Troia e Celso Longo, também por essas discussões, que serviram para alimentar as preocupações e as ideias aqui contidas.

A todos os colegas de trabalho editorial e em arte da Editora Scipione, que por impossibilidade de serem citados faço representar por Aurélio Gonçalves Filho, Maria Teresa Buco Porto e Sergio Suwaki Yutaka, por propiciarem a discussão quase cotidiana dos temas e assuntos relacionados à edição e à arte do livro didático e muito ensinarem, alimentando também este trabalho. 



\section{RESUMO}

Moraes, D. D. C. D. Visualidade do livro didático no Brasil: o design de capas e sua renovação nas décadas de 1970 e 1980. Dissertação de mestrado. Faculdade de Educação da Universidade de São Paulo. São Paulo, 2010.

Até o final da década de 1960, o livro escolar brasileiro era em sua maioria produzido dentro dos padrões técnicos e visuais da indústria livreira tradicional em relação estreita e participando do que se conhece como cultura escolar, em que a linguagem visual como modo de conhecimento e construção de significados não era devidamente reconhecida e valorizada. Com raras exceções, a visualidade do livro didático não tinha como referência a produção gráfica de melhor qualidade que aparecia em livros de literatura e outras mídias e não era produto de método projetual mais rigoroso e qualificado. Na década de 1970, com a expansão da indústria cultural e dos meios audiovisuais e o surgimento de novas referências de gosto particularmente para a juventude, a visualidade do livro didático praticada ficou ainda mais distante de seu público. As editoras existentes e as novas que surgiram com a expansão do ensino em todos os níveis, mesmo quando percebiam as mudanças de gosto ocorridas, ou não davam importância para esse fato, ou não sabiam como atualizar as linguagens de sua produção, ambos os aspectos sendo decorrentes da pouca cultura visual de seus dirigentes e do não reconhecimento do modo visual como expressão válida de conhecimento e do design como recurso para despertar o interesse pelo aprendizado e ferramenta de promoção de vendas. Será a editora Ática, por seu projeto editorial de inserção na produção de cultura mais ampla e de resposta às demandas decorrentes da vida política e cultural do momento vivido pelo país, que trará para o livro didático as mesmas preocupações com visualidade que precisava ter com seus produtos destinados ao público mais amplo. Assim, a editora promove uma profissionalização na produção visual, com a contratação de designers e ilustradores experimentados em outras mídias impressas, estas já bastante profissionalizadas na produção de linguagens que atingiam diversos públicos. A importância dada às capas, como meio de sedução para obter adoção entre os professores e adesão entre os estudantes, pela identificação com o universo visual desses segmentos, vai gerar uma renovação sem precedentes na visualidade do livro escolar e vai impulsionar editoras concorrentes a fazê-lo. As soluções gráficas originais de Ary Normanha, com a participação de Mário Cafiero, vão oferecer ao público a experiência com os significados criados pela linguagem visual em diálogo com o modo verbal, como atividade própria de uma cultura e de um aprendizado integrais. A par da ampliação da cultura imagética e das referências de gosto, as capas documentadas e analisadas mostram um momento em que o design do livro didático se equiparou ao melhor design encontrado em outros veículos da cultura no Brasil.

Palavras-chave: livro didático, visualidade, história editorial, design gráfico, história do design gráfico no Brasil. 
Moraes, D. D. C. D. Visualidade do livro didático no Brasil: o design de capas e sua renovação nas décadas de 1970 e 1980. [Schoolbook visual image in Brazil: cover design and its renovation in the 70's and 80's] Dissertação de mestrado. Faculdade de Educação da Universidade de São Paulo. São Paulo, 2010.

Until the end of the 1960's, Brazilian schoolbooks were in its majority produced according to the technical and visual standards of the traditional publishing industry, in close relation to what is known as "school culture", by which the visual language as a way of acquiring knowledge and creating meanings was not duly recognized and valued. With a few exceptions, the visual presentation of schoolbooks had no compare with better quality graphics that turned up in literature books and other media. Moreover, it was not the result of a more rigorous and qualified, thoughtful design. In the 70's, with the expansion of cultural industry and audiovisual media and the emergence of new taste trends particularly among the youth, the visual image of schoolbooks drifted apart from its public even more. The existing publishing houses and the ones founded during the spreading of education in all levels would either dismiss this fact or not know how to update the language of their books even if they have noticed that changes in taste had occurred. These issues were due to the scarce graphical knowledge of the publishers and their non-recognition of the visual aspect as a valid expression of knowledge and of the design as a means for arousing the interest in learning and as a sales promotion tool. Amongst the biggest publishing houses in Brazil, Ática was the one that treated textbooks with the same graphic concerns it has had for its products aimed to a broader public, once it had embarked on the project of participating in the wider cultural production, responding to the demands of cultural and political scenes in that particular period the country was living in. Thus, Ática promoted the professionalization of graphic design in the schoolbook area by hiring designers and illustrators experienced in other media that were already developing languages that reached a diverse public. Considered as a way to conquer teachers and its students through their identification with its visual image, the book cover gained a significance that would generate an unseen renewal in the graphic design of schoolbooks and impelled Ática's competitors to do the same. The original graphical solutions introduced by Ary Normanha, with the collaboration of Mário Cafiero, would make the public experience meanings provided by the dialogues between visual language and verbal language, an outcome of a more comprehensive culture and learning. Besides their enhanced appeal and the cultural imagery they bring about, the book covers registered and analyzed herein show a moment when the design of the schoolbooks was of the same quality as the design found in other cultural media in Brazil.

Keywords: textbooks, visual images, publishing history, graphic design, history of graphic design in Brazil. 


\section{SUMÁRIO}

APRESENTAÇÃO $\underline{11}$

PARTE | O LIVRO DIDÁTICO E SUA VISUALIDADE NA DÉCADA DE 1970 .15

1 A pesquisa sobre o livro didático no Brasil 17

1.1 Início e expansão da pesquisa sobre o livro escolar 17

1.2 Dificuldades da pesquisa e definição do objeto 19

1.3 A pesquisa no Brasil 21

1.4 A pesquisa sobre visualidade 23

2 O livro didático como objeto de pesquisa em design $\underline{26}$

2.1 Design e projeto 27

2.2 O livro didático nos congressos de pesquisa em design 29

3 Livro didático, visualidade, design e cultura $\underline{30}$

3.1 O caráter de uso do livro didático 30

3.2 A página (apenas) de texto 31

3.3 A página do livro escolar 37

3.4 A tradição visual do livro didático brasileiro 41

3.5 Visualidade e sociedade 44

3.6 Escola e visualidade 46

3.7 Design e livro didático 48

3.8 Os papéis da capa 50

4 Capas de livros didáticos nos anos 1970: um panorama $\underline{53}$

4.1 O crescimento da indústria editorial didática na década de 197053

4.2 A cultura de massas e os novos meios audiovisuais 55

4.3 As capas da década 57

4.4 1. ' grupo: as capas "tradicionais" ou "vernaculares" 58

$4.52 .^{\circ}$ grupo: a visualidade oscilante das capas novas "sem projeto" 64

4.6 3. ' grupo: as capas "inovadoras" ou "com projeto" 70

4.7 Uma conclusão parcial 80 
1 A expansão da Editora Ática e a busca da atualização visual

2 Os designers e suas referências

2.1 Ary Normanha e o design de revistas 89

2.2 A experiência de Mario Cafiero: a ilustração e edição de revistas 92

2.3 A Escola de Nova York e o design-ilustração 94

3 Os primeiros projetos

3.1 Os livros não-didáticos 96

3.2 A procura de uma linguagem para os dois atores do universo escolar, o aluno e o professor 100

4 As capas dos livros didáticos .104

4.1 As montagens fotográficas 104

4.2 A ilustração e a fotografia referencial 127

4.3 O cartum e a ilustração de humor 148

4.4 A tipografia nas capas da Ática 158

5 Esclarecimentos complementares 163

5.1 O alcance da renovação visual das capas da Ática 163

5.2 O design do miolo 165

5.3 Sobre a leitura das capas 167

1 Design de capas nos anos 1970 e 1980: uma síntese

2 Algumas reflexões possíveis

2.1 Livro didático, produto da indústria cultural portador de conteúdos: tem que comunicar 174

2.2 Papel pedagógico do design: ensino de uma linguagem e transmissão da cultura visual 175 


\section{APRESENTAÇÃO}

O presente trabalho incursiona numa área que se descobriu bastante nova dentro da pesquisa sobre o livro didático no Brasil: o da sua configuração material e visual. Mais restrito ainda, focaliza um de seus aspectos, a capa, embora aborde secundariamente também a visualidade de seu corpo "interno", ou seja, as páginas que suportam o conteúdo textual e imagético. Restringindo ainda mais o foco, aborda a produção de capas de um determinado período e, dentro dela, a produção de uma determinada editora e de seus designers. Cada uma dessas escolhas precisa ser antecipadamente justificada, embora se acredite que a leitura do trabalho o fará por si própria.

Em primeiro lugar, hoje é consenso que o livro didático, pela sua presença obrigatória e por largo período na educação e formação das pessoas, merece ser objeto de reflexão e pesquisa, tanto em enfoques pragmáticos relativos a seu uso atual na vida escolar como em enfoques históricos e teóricos mais abrangentes. Essa compreensão se reflete na quantidade crescente de estudos no país sobre a história do livro didático, sua produção e sua relação com as disciplinas e práticas escolares.

Também se reconhece que a imagem e os meios visuais de expressão cada vez mais ocupam lugar central na experiência e na comunicação dos indivíduos entre si e com as instituições sociais, em alguns casos até substituindo práticas anteriormente apoiadas nos modos exclusivamente verbal e escrito. Até por fazerem parte já da vivência infantil contemporânea, são considerados meios necessários à educação, que não pode abrir mão deles nas práticas de ensino e aprendizagem.

No entanto, a quase inexistência de pesquisas sobre a materialidade e a visualidade do livro didático parece indicar não ser ainda suficientemente reconhecido que o livro didático, como objeto material portador de informação visual, com uma presença tão constante e num período de formação e amadurecimento das pessoas, exerça efetivamente algum papel na educação delas para além do conteúdo disciplinar apresentado na forma de palavras e imagens impressas.

Em segundo lugar, e não desconectado desse ainda apenas suposto papel educativo, a visualidade materializada em um determinado livro didático é produto complexo do cruzamento de inúmeros fatores, como interesses institucionais, políticos e educativos, práticas sociais e profissionais, tecnologias e materiais disponíveis, demandas pedagógicas, mercadológicas e culturais e tudo o mais que caracteriza o livro didático como mercadoria e produto material e simbólico. No entanto, o que de maneira geral tem marcado a visualidade do livro didático em diversos períodos é uma distância e em alguns casos uma oposição à visualidade encontrada nos demais produtos impressos e manifestações culturais da sociedade em que se insere. Aqui já se pode pensar se ele educa ou não visualmente, se ele favorece a compreensão dos códigos produzidos por todos os níveis da cultura ou se se coloca em oposição a eles, para além, como se disse, dos conteúdos disciplinares que veicula. E do ponto de vista da eficácia de sua visualidade para a 
transmissão desses conteúdos, se sua identificação ou não com a visualidade vigente serve para mobilizar afetivamente ou desinteressar o estudante pela aprendizagem.

Por fim, é preciso justificar o período escolhido para a apresentação e análise da visualidade dos livros e particularmente das capas, bem como a produção específica analisada.

A década de 1970 é reconhecidamente a da expansão da indústria cultural no Brasil — ligada ao crescimento da urbanização e inserção mais profunda do país nos processos econômicos e sociais mundiais -, consolidando o que se iniciou na década anterior e mostrando uma profissionalização dessa produção e de seus agentes, seja na produção voltada para as amplas massas e com qualidade estética duvidosa e alienante, seja na produção com conteúdo e preocupações estéticas e de contestação das condições vigentes. A sociedade consome o que se the oferece, mas a despeito da censura e da repressão política por parte do regime, também resiste e luta por direitos, liberdade e cultura, e nesse terreno encontra obstáculos mas também os supera em realizações de alta inventividade em todos os campos da arte e da comunicação.

Como decorrência da própria expansão do ensino em todos os níveis, acentuada também nesta década, a indústria do livro didático se expande no país e, nesse quadro político e cultural, precisa configurar seu produto em acordo com o que supõe ser a demanda de seu público e conforme as novas condições tecnológicas da indústria gráfica. Em um regime visual determinado agora pela presença da televisão e da imprensa de massa, que se expandem naqueles anos, não vai ocorrer nem uma adesão pura e simples às características de linguagem decorrentes da presença desses meios nem uma ruptura total e imediata com a visualidade do livro escolar anterior a eles. Embora seus agentes reconheçam com maior ou menor consciência novas demandas na esfera simbólica por parte de um público que se "educa" também pela televisão e pelas revistas, essa percepção é inicialmente difusa e se dá num terreno em que pesam a própria tradição visual e as condições tecnológicas e de formação dos profissionais de produção do livro escolar e a relação deste com a cultura escolar.

As capas dos livros, além da função de proteção e identificação de uma obra, precisam cada vez mais assumir a função de persuadir seu público, num momento de aumento da competição e de transformação nas referências visuais e de gosto. Dentre as editoras, a Ática se destaca por melhor compreender essa nova situação. As novas capas, mais do que o livro como um todo, por sua referência às linguagens dos meios de comunicação e suas qualidades específicas, dialogarão melhor com seu público, professores e alunos, e propiciarão uma forte identidade e marca de contemporaneidade à editora, impondo um novo padrão, que será perseguido pelas demais concorrentes, resultando de forma geral numa atualização da linguagem visual do livro didático brasileiro e na sua aproximação com os demais produtos da indústria cultural.

Além da investigação de algumas relações entre visualidade e educação materializadas no livro didático, que dizem respeito à área da educação, este trabalho 
visa também oferecer uma contribuição pontual à pesquisa em história do design e da cultura material no Brasil. Pesquisa de caráter bastante recente, são tantos os objetos a serem investigados que o livro escolar ainda figura como mais um a merecer atenção, o que já justificaria a documentação e interpretação empreendidas. A identificação dos profissionais responsáveis por esses projetos e sua formação e metodologias de trabalho também podem contribuir para a compreensão do processo de inserção do profissional designer nos vários campos de atividade projetual e de institucionalização de sua profissão. 

PARTE I

O LIVRO DIDÁTICO E SUA VISUALIDADE NA DÉCADA DE 1970 



\section{A PESQUISA SOBRE O LIVRO DIDÁTICO NO BRASIL}

Na busca de precedentes e referências para a pesquisa que se pretendia fazer, centrada na configuração material e visual do livro didático em uma época que se supôs decisiva para a configuração do livro didático atual, procedeu-se a um levantamento da pesquisa sobre o livro didático já feita no Brasil tanto do ponto de vista de sua história como de sua materialidade e visualidade. Essa "pesquisa sobre a pesquisa" permitiu um contato com o estado da arte da pesquisa acadêmica no Brasil tanto nas áreas da história e práticas de uso do livro didático no Brasil, como nas áreas de história e de metodologia de projeto em design gráfico, e levou à constatação da quase inexistência de pesquisas sobre a visualidade do livro didático e à certeza da necessidade de se emprenderem trabalhos dessa natureza.

A pesquisa permitiu também uma conceituação mais precisa do objeto investigado, bem como informações objetivas e referências bibliográficas usadas para o desenvolvimento do próprio trabalho. Por isso, optou-se por apresentar aqui os resultados dessa "pesquisa sobre pesquisa" nos dois campos, o da história e práticas de uso do livro didático e o de sua história como objeto da cultura material.

\subsection{Início e expansão da pesquisa sobre o livro escolar}

A mencionada raridade de trabalhos sobre a visualidade e materialidade do livro didático parece se dever ao caráter recente da pesquisa sobre as edições didáticas não só no Brasil, mas no contexto mundial. Segundo Alain Choppin, pesquisador do Institut National de Recherche Pédagogique, na França, e talvez a mais importante autoridade acadêmica na área, há apenas trinta anos ela praticamente inexistia na maior parte dos países. Até então, a "banalidade" do livro escolar e sua função delimitada à escola e ao período de formação dos indíviduos não Ihe outorgavam o status de livro, merecedor de constar dos acervos de bibliotecas e de ser objeto de investigação acadêmica. Foi apenas a partir dos anos 1970 que o interesse por ele cresceu:

Após terem sido negligenciados, tanto pelos historiadores quanto pelos bibliógrafos, os livros didáticos vêm suscitando um vivo interesse entre os pesquisadores de uns trinta anos para cá. Desde então, a história dos livros e das edições didáticas passou a constituir um domínio de pesquisa em pleno desenvolvimento, em um número cada vez maior de países, e seria pouco realista pretender traçar um estado da arte exaustivo sobre o que foi feito e escrito e, mais ainda, do que se pesquisa e se escreve atualmente pelo mundo. (CHOPPIN, 2004, p. 549)

Sobre as razões da expansão da pesquisa sobre o livro didático:

Uma das razões essenciais é a onipresença — real ou bastante desejável — de livros didáticos pelo mundo e, portanto, o peso considerável que o setor escolar assume na economia editorial nesses dois últimos séculos. É impossível para o historiador do livro tratar da atividade editorial da maior parte dos países sem levar isso em conta: em um país como o Brasil, por exemplo, os livros didáticos correspondiam, no início do século XX, a dois terços dos livros publicados e representavam, ainda em 1996, aproximadamente $61 \%$ da produção nacional. (CHOPPIN, cit., p. 551) 
Ainda segundo o professor Choppin, outras razões seriam:

1) o interesse dos historiadores pelas questões relacionadas à educação e a constituição de centros de pesquisa a respeito;

2) o interesse dos povos pela recuperação ou construção das identidades culturais, a partir dos processos de descolonização e, mais recentemente, da fragmentação da União Soviética;

3) o progresso das técnicas de armazenamento de dados e documentos;

4) o reconhecimento da "planetariedade" e complexidade do livro didático como produto cultural, situado no cruzamento da cultura, da pedagogia, da produção editorial e da sociedade e de suas funções (referencial aos programas curriculares, instrumental para a aprendizagem, ideológica como instrumento de afirmação e valores dominantes, documental para o estudante construir suas próprias ideias).

No levantamento que faz sobre o estado da arte na pesquisa do livro didático, novamente Choppin é referência, apresentando e refletindo sobre as categorias dessas pesquisas. Embora mencionando que em uma pesquisa possa haver uma sobreposição de posturas,

[...] podemos nos arriscar a distinguir duas grandes categorias de pesquisa:

- aquelas que, concebendo o livro didático apenas como um documento histórico igual a qualquer outro, analisam os conteúdos em uma busca de informações estranhas a ele mesmo (a representação de Frederico Il da Prússia, ou a representação da ideologia colonial, por exemplo), ou as que só se interessam pelo conteúdo ensinado por meio do livro didático (história das categorias gramaticais, por exemplo);

- aquelas que, negligenciando os conteúdos dos quais o livro didático é portador, o consideram como um objeto físico, ou seja, como um produto fabricado, comercializado, distribuído ou, ainda, como um utensílio concebido em função de certos usos, consumido — e avaliado — em um determinado contexto. (CHOPPIN, cit., p. 554)

Assim, no primeiro caso, não se trata da história do livro didático, mas de como um tema histórico foi apresentado por esta mídia. O livro didático é tomado como documento para a pesquisa em história, externa à sua existência. Já no segundo caso, o livro didático é tomado em si, como objeto e produto fabricado e consumido num contexto próprio, tratando-se, portanto, de sua história. Nessa categoria:

[...] ao contrário, o historiador dirige sua atenção diretamente para os livros didáticos, recolocando-os no ambiente em que foram concebidos, produzidos, distribuídos, utilizados e "recebidos", independentemente, arriscaríamos a dizer, dos conteúdos dos quais eles são portadores. (CHOPPIN, cit., p. 554. Destaque meu)

A ênfase da pesquisa sobre livro didático, na maioria dos países, se deu e ainda se dá principalmente sobre a análise dos conteúdos, a imagem da sociedade que os livros apresentavam em períodos determinados, os autores, a permanência dos títulos, a história das editoras, a história dos métodos etc. Um aspecto particular identificado em pesquisas em todo o mundo é o papel que os livros didáticos tiveram na construção da identidade nacional, na formação das nações, como, por exemplo, o trabalho de Hector Cucuzza na Argentina, Yo argentino: la construcción de la Nación en los libros escolares (1873-1930), para citar apenas um dentre outros. 
Outras pesquisas investigaram o uso dos livros como instrumento do Estado em períodos de dominação ditatorial ou de ocupação estrangeira. Há estudos também sobre a influência local de obras estrangeiras (Cuore, de De Amicis, por exemplo, traduzido em diversas línguas). Mas, de maneira geral, pode-se afirmar que as pesquisas de cunho histórico têm um caráter nacional e se ocupam majoritariamente dos últimos dois séculos, justamente o período de formação das nacionalidades e das nações modernas, em que os livros didáticos foram instrumentos da construção e inculcação dos chamados mitos fundadores dessas nações. No entanto, Choppin aponta para resultados comuns às pesquisas de inúmeros países e em diversos períodos:

Conclui-se que a imagem da sociedade apresentada pelos livros didáticos corresponde a uma reconstrução que obedece a motivações diversas, segundo época e local, e possui como característica comum apresentar a sociedade mais do modo como aqueles que, em seu sentido amplo, conceberam o livro didático gostariam de que ela fosse, do que como ela realmente é. Os autores de livros didáticos não são simples espectadores de seu tempo: eles reivindicam um outro status, o de agente. O livro didático não é um simples espelho: ele modifica a realidade para educar as novas gerações, fornecendo uma imagem deformada, esquematizada, modelada, frequentemente de forma favorável: as ações contrárias à moral são quase sempre punidas exemplarmente; os conflitos sociais, os atos delituosos ou a violência cotidiana são sistematicamente silenciados. E os historiadores se interessam justamente pela análise dessa ruptura entre a ficção e o real, ou seja, pelas intenções dos autores. (CHOPPIN, cit., p. 557)

A atualidade dessa perspectiva de pesquisa ainda se justificaria a partir de uma constatação também universal a respeito do alcance do livro didático:

Uma vez que são destinados a espíritos jovens, ainda maleáveis e pouco críticos, e podem ser reproduzidos e distribuídos em grande número sobre todo um território, os livros didáticos constituíram-se e continuam a se constituir como poderosos instrumentos de unificação, até mesmo de uniformização nacional, linguística, cultural e ideológica. (CHOPPIN, cit., p. 557)

\subsection{Dificuldades da pesquisa e definição do objeto}

Embora não seja o objetivo aqui levantar exaustivamente o percurso das pesquisas, é importante mencionar as dificuldades que elas encontraram desde seu início, porque foram as mesmas que apareceram também neste trabalho. A primeira delas diz respeito à definição do próprio objeto, que se expressa em léxico variado, sem correspondência exata entre as diferentes línguas. Etimologicamente, há diversas origens para sua designação, com termos baseados no contexto escolar (schoolbook), na forma material (mannuel, manual), na autoridade do texto (textbook), na função (livro didático), por exemplo.

A primeira dificuldade relaciona-se à própria definição do objeto, o que se traduz muito bem na diversidade do vocabulário e na instabilidade dos usos lexicais. Na maioria das línguas, o "livro didático" é designado de inúmeras maneiras, e nem sempre é possível explicitar as características específicas que podem estar relacionadas a cada uma das denominações, tanto mais que as palavras quase sempre sobrevivem àquilo que elas designaram por um determinado tempo. (CHOPPIN, cit., p. 549) 
A indefinição de fronteiras também dificultaria a caracterização desse objeto: catecismos, vulgarização científica, lazer poderiam estar incluídos. Circe Bittencourt assim define o que são livros didáticos: todos os impressos com intenção didática, que constituem um gênero que reúne muitos gêneros (cartilhas para aprender a ler, antologias, manuais, paradidáticos etc.) e participam da circulação de ideias:

Para os pesquisadores de livros o livro didático é toda obra produzida com a intenção de ser material escolar, ou seja, a ser utilizado em sala de aula. O livro didático e os denominados paradidáticos acabam sendo, na verdade, livros didáticos. Um exemplo dessa dimensão do livro didático pode ser fornecida pelos clássicos ou religiosos como os Os Lusíadas, a Bíblia e outros. Ao serem editados especialmente para servir a fins pedagógicos, ou seja, quando sofrem adaptações de linguagem ou alterações no conteúdo, transformam-se em livros didáticos. [...] Um clássico da literatura quando adaptado, mesmo que apenas incluindo exercícios a serem feitos por alunos, torna-se igualmente um livro didático. (BITTENCOURT, 1995, p. 389)

Outra definição bastante abrangente é a de João Batista Araújo e Oliveira: Iivro didático é o livro adotado na escola (OLIVEIRA, 1984, p. 11). Assim, diversas obras de Monteiro Lobato escritas entre 1920 e 1940 poderiam ser caracterizadas como obras didáticas, bem como toda uma literatura atual produzida em função dos conteúdos curriculares e divulgada sobretudo no meio escolar.

No entanto, qualquer que seja o subgênero tomado dentro desse gênero abrangente que o define, o livro didático apresentaria uma complexidade ímpar, que faz dele um "objeto de múltiplas facetas", na ótica de Circe Bittencourt, que assim resumimos:

O livro didático é, em primeiro lugar, uma "mercadoria" que obedece à lógica de produção e de comercialização determinadas pelas técnicas disponíveis e por interesses de mercado; mais especificamente, é um "objeto da indústria cultural". Mas é também "um depositário de conteúdos escolares" que "realiza uma transposição do saber acadêmico para o saber escolar no processo de explicitação curricular". Em terceiro lugar, é um instrumento pedagógico com uma larga tradição, que "elabora as estruturas e as condições de ensino para o professor" e que "produz uma série de técnicas de aprendizagem" (BITTENCOURT, 1995, p. 72). Por fim, "O livro didático é um importante veículo portador de um sistema de valores, de uma ideologia, de uma cultura (BITTENCOURT, 1997, p. 72. Grifos da autora). Essa complexidade do livro didático como produto cultural é o que determina a validade de várias abordagens de pesquisa realizadas nos mais diversos campos, da história à economia, da sociologia à pedagogia, da política ao design.

No entanto, essa definição contém em si uma restrição. Esse livro complexo, que transpõe o saber acadêmico para conteúdos curriculares a serem ensinados e que veicula o próprio método e técnica de aprendizagem não é qualquer livro adotado na escola, e, sim, unicamente aquele que se propõe como instrumento ou ferramenta de ensino de um conteúdo abrangente estabelecido pelos programas curriculares de cada disciplina. Dessa definição de livro didático ficam na prática excluídos outros tipos de livros usados na escola, aos quais cabe com propriedade o rótulo de paradidáticos, pois têm uma função auxiliar aos propriamente didáticos e ao conteúdo curricular. 
Assim, Kazumi Munakata, nas conclusões de sua tese de doutorado, Produzindo livros didáticos e paradidáticos, ressalta o caráter de uso do livro didático como intrínseco à sua constituição:

Pois, a rigor, livro didático não é para ser lido como se lê um tratado científico — postura adotada por muitos críticos do conteúdo dos livros didáticos. Livro didático é para usar: ser carregado; ser aberto; ser rabiscado (não, isso não pode, o livro não pode ser consumível!); ser dobrado; ser lido em voz alta em alguns trechos e, em outros, em silêncio; ser copiado (não se pode consumi-lo!); ser transportado de volta a casa; ser aberto de novo; ser "estudado". Raros livros didáticos [...] são efetivamente lidos de cabo a rabo, do mesmo modo que ninguém lê um dicionário ou uma enciclopédia de A a Z [...].

Objeto para ser usado, o livro didático implica não uma relação direta e imediata do aluno e do professor com o conteúdo, esse mundo platônico de formas inteligíveis, mas antes de atividades, práticas e fazeres, numa situação efetiva de ensino e aprendizagem. (MUNAKATA, 1997, p. 203-204)

Essa definição é importante para este trabalho, pois particulariza o livro didático dentre os demais e é a base para se identificar sua materialidade e visualidade específicas.

Voltando à questão das dificuldades envolvidas na pesquisa sobre o livro didático, além da ausência em acervos e bibliotecas é preciso mencionar a dispersão das fontes e de trabalhos produzidos avulsamente, abordando aspectos muito particulares e diversos, muitas vezes sem clareza de objetivos e suficiente qualidade científica, havendo principalmente poucas obras de síntese:

A segunda dificuldade diz respeito ao caráter recente desse campo de pesquisa: as obras de síntese ainda são raras e não abrangem toda a produção didática nem todos os períodos; a produção científica que trata especificamente da história da literatura e das edições didáticas constitui-se essencialmente de artigos (geralmente capítulos de livros) publicados em revistas ou livros (de uns tempos para cá também em sites) onde, na maior parte das vezes, ninguém pensaria em procurá-los; ainda é preciso alertar que fazer um recenseamento dessa produção partindo apenas de títulos de artigos ou de livros mostra-se fonte de desilusões e de incertezas. (CHOPPIN, cit., p. 549)

\subsection{A pesquisa no Brasil}

No entanto, apesar das dificuldades mencionadas e do caráter recente das pesquisas sobre o livro escolar, em palestra proferida no simpósio internacional Livro Didático - Educação e História, ocorrido em novembro de 2007 em São Paulo, o professor Choppin chamou a atenção para o grau de maturidade hoje atingido pelas pesquisas, relacionando trabalhos importantes em diversos países, entre eles o de Circe Bittencourt, a partir de 1993 no Brasil, e a constituição de bancos de dados integrados (Emmanuelle na França, Edisco na Itália, Livres no Brasil, entre outros) e sites de pesquisa em mais de quarenta países, que reúnem a documentação das obras e bibliografia da maneira mais extensiva possível, permitindo ao pesquisador superar o trabalho artesanal e fornecendo condições de pesquisa antes inexistentes. No Brasil, a maturidade das pesquisas sobre o livro didático pode ser constatada por trabalhos que abrangem todos os conteúdos acima referidos, além da mencionada tese de doutoramento de Circe Bittencourt, que, focalizando 
os manuais de história brasileiros de 1820 a 1910, analisa o livro didático em toda a sua complexidade de produto cultural e mercadoria, abrangendo de sua concepção autoral e editorial até sua utilização como instrumento pedagógico por professores e alunos.

Há, assim, um conjunto de trabalhos que abordam aspectos relevantes na compreensão da gênese do livro didático no Brasil, suas transformações em relação às demandas de cada novo projeto de organização escolar ou plano de aquisição e distribuição governamental, sua contribuição para a difusão da leitura ou adequação a programas específicos das disciplinas, seu papel como veículo de ideologias, particularmente dos segmentos dirigentes da sociedade a partir do controle do Estado e suas instituições, dentre as quais a escola, seu caráter de mercadoria voltada para o lucro de segmentos empresariais etc.

A maior parte dos trabalhos diz respeito, como era de se esperar, às relações entre cultura escolar e livro didático, mais precisamente, ao conteúdo expresso nos livros em relação ao conhecimento construído em cada disciplina científica, mas também há trabalhos sobre o uso do livro e veiculação dos conteúdos nas aulas. A leitura, os conteúdos gramaticais e o ensino de História são os mais abordados, seguidos dos de Ciências e de Matemática.

Mas há também investigações que relacionam a história dos livros à história das próprias disciplinas, como, por exemplo, o trabalho de Marcia Razzini, O espelho da nação: a Antologia Nacional e o ensino de português e de literatura (1838-1971)'. O estudo das origens e da longa presença dessa obra didática de Fausto Barreto e Carlos de Laet no ensino secundário não só revela seu papel na implantação da cultura brasileira na escola, mas permite a compreensão do próprio surgimento das disciplinas de Língua Portuguesa e de Literatura no currículo nacional. Em comunicação apresentada na 26. Reunião Anual da ANPEd - Associação Nacional de Pós-Graduação e Pesquisa em Educação, afirma a autora:

O livro didático pode se constituir também em fonte privilegiada para a contextualização de práticas escolares, ocupando papel de destaque na recente história das disciplinas escolares e na história do currículo. Nesse sentido, o livro didático é considerado um "espaço de memória" para a história da educação na medida em que reflete, ao mesmo tempo, uma "imagem sistêmica da escola que ele representa" e uma imagem da "sociedade que o escreve e que o utiliza", seja através da materialização dos programas como "suporte curricular" que ele é, seja através das "imagens e valores dominantes da sociedade" que ele veicula, seja ainda através das "estratégias didáticas" e práticas de ensinoaprendizagem que ele expressa [...] (RAZZINI, 2003.)

Se a história das editoras e suas edições já conta com uma obra de fôlego como O livro no Brasil: sua história, de Laurence Hallewell (2007), a história das editoras e suas edições especificamente didáticas já é mais rara e encontra dificuldades na precária conservação de acervos, tanto dos livros como de informações comerciais. Só muito recentemente as editoras vêm se preocupando em organizar seus acervos com vistas a oferecê-los para pesquisadores, como fez a Editora Na-

${ }^{1}$ Tese de doutorado, Instituto de Estudos de Linguagem, Universidade Estadual de Campinas. Campinas: 2000. cional, que encarregou a historiadora Maria Rita de Almeida Toledo dessa tarefa e posteriormente transferiu seu acervo para a Universidade Federal de São Paulo. Outro exemplo é a doação do acervo de documentos comerciais e administrativos 
da mais antiga editora em atividade no país, a Francisco Alves, para a Universidade Federal Fluminense, constituindo o Centro de Memória Editorial Brasileira, dirigido pelo pesquisador Aníbal Bragança.

Numa direção contrária aos trabalhos que se ocupavam em denunciar genérica e abstratamente o comprometimento ideológico dos livros didáticos e sua insuficiência de conteúdo em relação ao conhecimento científico, a tese de doutorado de Kazumi Munakata, já citada, tem o mérito de examinar a concretude do processo de produção do livro escolar no Brasil na década de 1990. Com base em entrevistas com profissionais de importantes editoras e com exame direto das condições e dos aspectos técnicos envolvidos na edição e na editoração, o trabalho apresenta as práticas efetivas de seus agentes e contribui para a sua compreensão como produto da indústria cultural com papel fundamental na educação do país, com todas as contradições que isso implica. Ideias e sua materialidade específica são apresentados como resultantes de condições e práticas concretas investigadas nos editoriais e departamentos de arte das editoras.

Dado o papel do Estado brasileiro na circulação dos livros didáticos, pesquisas se ocupam dessas relações em cada momento da história do país. Com o alcance e as dimensões que tomaram as compras governamentais a partir dos anos 1990, a política do livro didático é particularmente analisada em trabalhos mais recentes.

Têm sido também objeto de pesquisas, ainda que em bem menor grau, o impacto das tecnologias na produção dos livros e materiais a ele associados (cd-rom etc.), bem como a influência dos livros na própria constituição dessas tecnologias.

\subsection{A pesquisa sobre visualidade}

Sobre o que diz respeito diretamente ao escopo deste trabalho, é de se notar a quase ausência de pesquisas sobre os aspectos materiais e gráfico-visuais do livro didático. O importante simpósio internacional Livro Didático - Educação e História, realizado em 2007 em São Paulo, dá uma radiografia bem precisa a respeito. Dos 176 artigos apresentados em suas comunicações e constantes do caderno de resumos, apenas um trata diretamente de aspectos da configuração visual do livro didático ${ }^{2}$ e quatro versam sobre iconografia encontrada principalmente em livros de História.

O II Seminário Brasileiro Livro e História Editorial, do LIHED - Núcleo de Pesquisa sobre Livro e História Editorial no Brasil, da Universidade Federal Fluminense, realizado entre 11 e 15 de maio de 2009, expressou a importância da pesquisa sobre o livro didático em seus múltiplos aspectos dentro da pesquisa sobre a história dos livros e das editoras. Dentre conferências, colóquios, mesas redondas e comunicações tratando de temas como práticas de leitura, cultura letrada, duzentos anos do livro no Brasil, relações culturais/editoriais entre França e Brasil, bibliotecas, produção, mercado, profissionalização, gêneros de livros, direitos autorais e muitos outros, houve espaço privilegiado para os temas relacionados ao livro escolar. Colóquios e mesas redondas específicas sobre livros e leitura na escola, bibliotecas escolares, história das editoras, acervos de livros didáticos, cartilhas, alfabetização e

2 BOCCHINI, Maria Otilia. Legibilidade visual e projeto gráfico na avaliação de livros didáticos pelo PNLD. 
formação de professores, livros de História e Geografia, educação de jovens e adultos, política educacional e mercado escolar foram realizados, com a apresentação de 32 comunicações ou palestras. Um número bastante expressivo, mas em que apenas dois textos tratavam de aspectos gráficos do livro escolar. ${ }^{3}$

Sobre esta predominância da análise do conteúdo textual, parece não ser uma característica exclusiva da pesquisa desenvolvida no Brasil. Segundo Choppin:

Por razões que dizem respeito à formação de pesquisadores e à carência de instrumentos apropriados, as análises dos livros didáticos, independentemente de suas problemáticas, ficam tradicionalmente restritas — ao menos no Ocidente — à análise de texto. $\mathrm{O}$ privilégio quase exclusivo conferido à análise textual, mesmo considerando que desde o final do século passado a parte do livro destinada à iconografia não tenha deixado de crescer, se solidificou pelo desenvolvimento de métodos e de instrumentos de análises linguísticas, destacando a análise lexicométrica. Foi no final dos anos 1980, com os avanços da semiótica, o impulso da história das mentalidades e o interesse pelas questões de vulgarização das ciências, que recorreu a muitos esquemas e gráficos, que o livro didático deixou de ser considerado como um texto subsidiariamente "enfeitado" de ilustrações, e para que a iconografia didática - e a articulação semântica que une o texto e a imagem — tenha sido levada em conta. (CHOPPIN, cit., p. 599)

Assim, pesquisas sobre o livro didático como objeto em si, portador de uma configuração, feita de "papel e tinta" (Monteiro Lobato), mas também por formatos, tamanhos, letras, margens e imagens, são ainda bastante raras, embora essa configuração seja própria e muito particular do livro didático como gênero específico.

Também têm sido negligenciadas as características "formais" dos livros didáticos. A organização interna dos livros e sua divisão em partes, capítulos, parágrafos, as diferenciações tipográficas (fonte, corpo de texto, grifos, tipo de papel, bordas, cores, etc.) e suas variações, a distribuição e a disposição espacial dos diversos elementos textuais ou icônicos no interior de uma página (ou de uma página dupla) ou de um livro só foram objeto, segundo uma perspectiva histórica, de bem poucos estudos, apesar dessas configurações serem bastante específicas do livro didático. Com efeito, a tipografia e a paginação fazem parte do discurso didático de um livro usado em sala de aula tanto quanto o texto ou as ilustrações. (CHOPPIN, cit., p. 599. Grifo meu.)

Mas os aspectos materiais e visuais do livro didático podem aparecer em trabalhos desenvolvidos com outros objetivos e motivações. Antonia Terra Fernandes (2004) obtém relatos orais em busca de reconstruir o cotidiano escolar e identificar a importância do livro didático para as gerações que frequentaram a escola entre as décadas de 1940 e 1970, e neles aparecem as lembranças da materialidade e visualidade dos livros:

3 São eles: Aline Frederico, Parâmetros para o projeto gráfico de dicionários infantis ilustrados; Isabel Cristina Alves da Silva Frade, Livros brasileiros de alfabetização: entre ordenamentos gráficos e a escolarização da escrita. Final do século XIX e início do século XX.

Como explica Pierre Nora, entre as inúmeras especificidades da memória, ela "se enraíza no concreto, no espaço, no gesto, na imagem, no objeto" (1993, p. 9). Dessa forma, os livros também são lembrados por suas materialidades (como seus aspectos físicos cor, grossura, capa dura, etc.), pelas disciplinas a que se referem (português, história, admissão, etc.) e por terem formatos distintos de acordo com a série:

"O livro de geografia era um livro pequeno, capa dura. Os mapas eram todos de bico de pena, preto-e-branco." (Entrevistado 1)

"E eu me lembro muito bem da escola, da cartilha tinha uma menina de trança desenhada na capa, não era foto [...] E aí em outubro a gente recebia o primei- 
ro livro de leitura. Desse eu tenho uma vaga lembrança dele... não sei se era da mesma autora ou não. As gravuras eram geralmente bico de pena, não eram fotografias e não eram coloridas. Mesmo os do ginásio, que depois você me perguntou, das gravuras. O livro de ciências era bastante ilustrado, mas geralmente com desenhos mesmo, que eram feitos com nanquim e depois para editar e tudo. E a gente não tinha essa coisa de livro colorido de fotografia, nada assim.

[...] Então do primário para o ginásio notei essa diferença dos livros. Um é capa dura, parecia livro de adulto e a gente tinha uma certa veneração com os livros." (Entrevistado 3)

Há lembranças de imagens específicas e do estilo das ilustrações:

"O livro de História Sagrada trazia sugestões. Por exemplo: uma figura que ocupava uma página inteira, em bico de pena, era a fuga de José, do Egito. As imagens sagradas dos livros didáticos se transformavam em painéis do artesanato popular." (Entrevistado 1)

"Essa era preto-e-branco... a história de uma família chegando em Porto Alegre, num navio, pelo Guaíba. Então era a família, você via o navio, a família no convés do navio, Porto Alegre e a ponte." (Entrevistado 5)

Assim, como objeto portador de uma materialidade e de uma visualidade, pode-se supor que o livro didático veicule mais do que o conteúdo escrito em suas páginas. Em se tratando de livros escolares, com uso continuado e localizado nos anos de formação do indíviduo, é lícito acreditar-se que sua configuração também ensine alguma coisa e tenha alguma consequência tanto na predisposição ou não para um convívio com os livros em geral após a vida escolar, como no gosto ou formação estética geral. 


\section{O LIVRO DIDÁTICO COMO OBJETO DE PESQUISA EM DESIGN}

Outra abordagem possível de investigação sobre a visualidade do livro didático poderia ser encontrada nos estudos no campo do design gráfico, tanto como objeto de pesquisa em história de um produto da cultura material como em metodologia de projeto.

No primeiro caso, a pesquisa em história dos objetos de design em geral é muito recente no Brasil, mais ainda do que a pesquisa no campo da história do livro didático, e são relativamente poucos os objetos de cultura material já abordados pela investigação acadêmica. No segundo caso, o do estudo de um tipo de projeto voltado para dar corpo a materiais impressos destinados às atividades de ensino e aprendizagem, não se produziu ainda uma reflexão sistematizada que abarcasse e generalizasse experiências e práticas isoladas e que ultrapassasse o tratamento empírico dado por muitos à maior parte das questões envolvidas.

Na questão da história de objetos da cultura material, a precedência da tão recente pesquisa iniciada no país foi para a produção que a academia considerava efetivamente design no Brasil, a vinculada à linguagem modernista e seus praticantes, pois "Embora não exista o profissional diplomado em design até a primeira metade do século XX no Brasil, 'há a existência de um campo de design moderno, que propicia através da evolução dos contextos social, cultural, econômico e fabril a sua constituição e a ação de seus personagens'" (BRAGA, 2005, p. 21)4.

Dessa produção moderna faz parte principalmente, no caso do design de produto, o projeto de móveis, surgido como consequência do desenvolvimento da arquitetura moderna, em geral feito pelos próprios arquitetos, para ocupar os interiores criados. E, no caso do design gráfico, a produção oriunda dos escritórios constituídos na década de 1950 e 1960, ligados ao surgimento dos primeiros cursos de design no país.

Embora o caráter recente dessa pesquisa faz com que reste muito ainda a investigar sobre o próprio design modernista, existe uma tradição, só há menos de 30 anos contestada, de rejeitar o que não se encaixa nessa produção como não pertencendo ao campo do design, excluindo dele praticamente todos os produtos da cultura material que fizeram e fazem parte da vida de qualquer população a partir das revoluções industriais.

Para Adrian Forty, o interesse pelo estudo dos objetos comuns, da nossa vida cotidiana — menção que pode ser estendida ao livro didático — ficou muito tempo prejudicado pela consideração de que apenas os objetos desenhados segundo a busca da "boa forma" propugnada pelo design europeu de matriz bauhasiana e vistos como uma manifestação da arte, seriam design. A história do design seria

4 Essa história, que evidentemente não será tratada aqui, é desenvolvida pelo autor particularmente no Capítulo 1 - Implantação e desenvolvimento do campo profissional do design moderno no Brasil. exclusivamente a história da produção desses designers e, no máximo, de seus precursores, como aparece em obras como Pioneiros do design moderno, de Nikolaus Pevsner, e Art and Industry, de Herbert Read. Essa visão, antes de tudo,

[...] obscureceu o fato de que o design nasceu em um determinado estágio da história do capitalismo e desempenhou papel vital na criação da riqueza industrial. 
[...] Qualquer que seja o grau de imaginação artística esbanjado no design de objetos, ele não é feito para dar expressão à criatividade e à imaginação do designer, mas para tornar os produtos vendáveis e lucrativos. Chamar o design industrial de "arte" sugere que os designers desempenham o principal papel na produção, uma concepção errônea, que corta efetivamente a maioria das conexões entre design e os processos da sociedade. (FORTY, 2007, p. 11 e 13).

A história do design como história do design exclusivamente modernista, em que não caberiam todos os demais objetos desenhados, produzidos e efetivamente consumidos pela sociedade, estaria, segundo Rafael Cardoso, pautada pelas próprias necessidades de afirmação social de uma nova categoria profissional:

Como em toda profissão nova, a primeira geração de historiadores do design teve como
prioridades a delimitação da abrangência do campo e a consagração das práticas e dos
praticantes preferidos da época. Sempre que um grupo toma consciência da sua identi-
dade profissional, passa a se diferenciar pela inclusão de uns e pela exclusão de outros,
e uma maneira muito eficaz de justificar essa separação é através da construção de ge-
nealogias históricas que determinem os herdeiros legítimos de uma tradição, relegando
quem fica de fora à ilegitimidade. As primeiras histórias do design, escritas durante o
período modernista, tendem a impor uma série de normas e restrições ao leitor, do tipo
'isto é design e aquilo não','este é designer e aquele não' [...]. (CARDOSO, 2004, p. 12-13.)

\subsection{Design e projeto}

Hoje é possível ter clareza de que design não é prerrogativa do objeto desenhado segundo os cânones do modernismo informado pelas vanguardas artísticas e realizado pela indústria de ponta, mas está envolvido em toda a produção de objetos por toda e qualquer indústria, mesmo antes de sua completa mecanização. Para haver design basta que haja a existência de uma etapa claramente definida de preparação de modelos, matrizes e instruções de execução, separada de uma etapa seguinte de fabricação propriamente dita, como forma de garantir a produção de objetos por outros trabalhadores, com o mínimo de variação possível, caracterizando uma primeira divisão básica e necessária de trabalho na indústria, e procurando responder a necessidades e anseios do público a que pretende atingir para se realizar como mercadoria (cf. CARDOSO, 2004, p.14-16 e FORTY, 2007, p. 48-59).

Ou seja, como estabelece Renato De Fusco, identifica-se a presença do design quando os fatores projeto, produção, venda e consumo integram um só processo unitário e final, como eventos ou momentos sequenciais relacionados e dependentes entre si (DE FUSCO, 1993, p. 144-161).

Mesmo sem utilizar exatamente esta formulação, Adrian Forty mostra como as condições estipuladas por De Fusco são preenchidas na produção de cerâmica de Josiah Wedgwood, na Inglaterra do século XVIII, sob o regime de manufatura, antes, portanto, da substituição da ferramenta pela máquina promovida pela primeira revolução industrial. Forty descreve os eventos e a pesquisa tecnológica e inclusive estética empreendida por esse capitalista, a introdução pioneira de procedimentos e divisão de trabalho e, em particular, a atividade dos que considera os primeiros designers, numa produção ainda baseada na manufatura, portanto antes até do emprego de máquinas movidas a energia térmica (FORTY, 2007, p. 43-59). 
Segundo essa mesma concepção, talvez se possa dizer que a produção do livro antecedeu a da cerâmica quanto à presença do design, isto já no Renascimento e no surgimento do capitalismo comercial e da idade moderna. Enquanto suporte, o livro mudou pouco nesses 500 anos, conservando algumas características praticamente inalteradas apesar das grandes diferenças na forma de produzi-lo, essa, sim, transformada pela revolução industrial e o que se seguiu a ela. Mas desde a atividade de Aldo Manuzio, em finais do século XV, certamente o livro é uma das primeiras mercadorias produzidas em escala mais ampla, ainda que artesanalmente, e que envolvia toda uma atividade de planejamento de grande complexidade, desde a tradução ou produção de originais de texto, o desenho e a produção prévia dos caracteres tipográficos, a definição de formato e campo a receber a impressão, a produção e escolha de papéis e tintas que interagissem adequadamente, a construção de uma matriz e o processo de produção de cópias, e a encadernação final ${ }^{\mathbf{5}}$. No mínimo pode-se dizer que é uma atividade manufatureira que antecipa procedimentos que só se generalizarão com a revolução industrial, e que inaugura, ainda que timidamente, a era da reprodutibilidade técnica, com todas as consequências para a cultura e a arte e que se aprofundarão mais tarde com a ampliação da escala de tiragem e com os novos suportes e meios de comunicação.

No entanto, se se pode dizer que sempre existe design no caso da produção de livros e outros produtos, nem sempre existe projeto em sua acepção plena. No caso de uma capa de livro, mas também do seu interior, as instruções para reprodução estão consubstanciadas na própria matriz, que será reproduzida tecnicamente sem mais interferência de trabalhadores, a não ser no controle da reprodução com base em uma prova-referência da matriz. Assim, toda a concepção do projeto está concentrada nessa matriz, que pode ou não ter sido desenvolvida de forma a responder aos principais aspectos de produção, circulação e significado cultural com a consciência, a intencionalidade e o domínio dos meios que caracterizam o exercício do projeto. Se a reprodutibilidade exige algum grau de planejamento e projetação, outros aspectos decisivos no campo da circulação e do consumo, envolvendo, portanto, o imaginário e o simbólico, podem estar sendo ignorados.

Algumas situações exemplificam o enfraquecimento do sentido de projeto. Procedimentos estandardizados podem ser aplicados automaticamente e sem reflexão a produtos particulares, sem considerar suas características específicas e

5 Enric SATUÉ (2005) traça o perfil de Aldo Manuzio, intelectual italiano que se tornou editor, tipógrafo e comerciante de livros, impulsionando a invenção de Gutemberg na construção do livro moderno, agenciando a criaçãa de fontes tipográficas, entre as quais 0 itálico, inventando a brochura e 0 livro de pequeno formato para a popularização dos clássicos gregos e latinos que ele e outros humanistas traduziu, e apresenta um panorama da produção livreira e das atividades envolvidas nos seus primórdios. contextos diferenciados de uso. Hábitos produtivos podem se tornar vícios cristalizados que não acompanham e não percebem as transformações tecnológicas ocorridas no próprio processo produtivo, o que vai aparecer como inconsistência de linguagem no próprio objeto. Também, a linguagem pode se apoiar em modelos já superados por outras referências produzidas socialmente e principalmente não se vincular a qualquer projeto ou intenção cultural que se afirme na sociedade, resultando em soluções esvaziadas de sentido e deslocadas. Por fim, por razões relacionadas à história de um determinado segmento produtivo, a atividade de projeto pode estar sendo exercida por profissionais não qualificados para traduzir as complexas relações entre projeto, produção, venda e consumo envolvidas no design de um produto. 


\subsection{O livro didático nos congressos de pesquisa em design}

Apenas a partir dessa compreensão do design além da dimensão estética, ou meIhor, de que a própria dimensão estética é resultado de condições de produção em sentido amplo, é que está sendo possível constituir uma história do design como história da cultura material das sociedades industriais e abranger toda uma produção anônima, tanto quanto a produção autoral, do desenho de objetos que povoam nossa vida cotidiana. E, como história da cultura material, essa história do design pode compor e integrar a história das próprias sociedades.

Assim, no Brasil, é um marco fundamental o lançamento do livro O design brasileiro antes do design: aspectos da história gráfica: 1870-1960, organizado por Rafael Cardoso, que apresenta artigos sobre outros objetos do design gráfico brasileiro até então negligenciados, como as cartas de baralho, os rótulos litográficos, livros e revistas, entre outros ${ }^{6}$. Esta publicação foi seguida por outras, como o 0 design gráfico brasileiro - anos 60, organizado por Chico Homem de Melo, que abarcou revistas, capas de livro, discos, cartazes, identidade visual e o ensino de design daquela década?.

Entre os muitos objetos - produtos ou impressos - a terem sua genealogia e materialidade ainda investigadas, o design do livro e o do livro didático em particular começam muito timidamente a ser objeto de pesquisa, como revelam os números dos últimos congressos de pesquisa em design.

No 4. ${ }^{\circ}$ Congresso Internacional de Pesquisa em Design, organizado pela ANPED (Associação Nacional de Pesquisa em Design) e realizado em outubro de 2007, de 90 artigos apresentados, entre 10 de história ou semiótica do design, nenhum se ocupava especificamente do design de livros, e entre 10 de design gráfico, design informacional e comunicação visual, três tratavam diretamente de livro, um de catálogos técnicos e um de design da informação em situações didáticas.

No 8. Congresso Brasileiro de Pesquisa e Desenvolvimento em Design, organizado pela AEND (Associação de Ensino e Pesquisa em Nível Superior de Design no Brasil) e realizado em outubro de 2008, num universo de 548 artigos, 51 dedicavam-se à história do design, dos quais 8 tratavam do livro, e dentre eles apenas dois do livro didático.

O 4. ${ }^{\circ}$ Congresso Internacional de Design de Informação, organizado pela SBDI (Sociedade Brasileira de Design da Informação) e realizado em setembro de 2009, teve cinco trabalhos relacionados à escola ou ao livro, com um deles tratando diretamente do livro didático sob o ponto de vista de sua linguagem e história. ${ }^{\mathbf{8}}$

Já no 5. ${ }^{\circ}$ Congresso Internacional de Pesquisa em Design, da ANPED, realizado em outubro de 2009, foram dois os trabalhos sobre livro infantil, nenhum sobre livro escolar especificamente.

Este quadro mostra que a pesquisa da história dos objetos materiais e sua visualidade se iniciou no Brasil, mas que há muito a fazer em todos os campos, e que o livro didático, a que se dedica este trabalho, é um deles.

\footnotetext{
6 São Paulo: Cosac Nä̈fy, 2005.

7 São Paulo: Cosac Naîfy, 2006.

8 Elisabelle Costa, José Fábio Luna, Igor Colares e Solange Coutinho. Um estudo sobre a linguagem visual gráfica nos livros didáticos pernambucanos ao longo das décadas de 1860 a 1990.
} 


\section{LIVRO DIDÁTICO, VISUALIDADE, DESIGN E CULTURA}

Antes de apresentar os resultados da pesquisa sobre as capas de livros didáticos na década de 1970, faz-se necessário empreender um esforço de explicitação de alguns raciocínios que envolvem conceitos de campos diversos que serão utilizados na análise visual das capas. Não se trata de uma exposição teórica generalizadora e abrangente sobre leitura de imagem nem da definição dos elementos componentes do objeto livro e de tudo o que está envolvido no seu design, o que pode ser encontrado em obras temáticas e manuais técnicos; mas apenas de um exercicício de reconhecimento do que determinadas conformações visuais presentes em páginas de livros podem comunicar, para além do conteúdo escrito, como forma de sensibilizar para o fenômeno visual e seu potencial informativo. Também se tenta buscar na tradição do livro didático brasileiro em sua relação com a cultura escolar e com a cultura em geral as raízes do que vai se chamar insensibilidade ou ignorância do fenômeno visual como modo de conhecimento e produção de significado, que se acredita estar na base da inconsistência da maioria das soluções de capas do período analisado.

\subsection{O caráter de uso do livro didático}

A configuração visual de qualquer livro escolar, diferente da de qualquer outro tipo de livro, revela inequivocamente seu caráter de uso específico voltado para a escola ou para o estudo individual determinado pela escola. Isto aparece já nas primeiras coletâneas de textos para leitura e estudo produzidas no século XIX no Brasil, em que algum tipo de organização, cronológica ou temática, e a presença de comentários e notas explicativas explicitam visualmente seu propósito. Aparece também nas primeiras cartilhas brasileiras, em que a apresentação das unidades silábicas, indo das mais simples às mais complexas, com seus respectivos exemplos na forma de vocábulos e frases, referenciados a uma ilustração, resultam em páginas com desenho diferenciado e especial. E certamente aparece nos livros de disciplinas que não podem prescindir de informações visuais que complementam, interpretam ou traduzem as informações veiculadas pelo texto propriamente dito.

Em suma, o livro didático deve ser produzido em adequação a parâmetros que se imagina constitutivos de um instrumento auxiliar do processo de ensino e aprendizagem. Isso implica uma série de critérios já apontadas: conteúdo adequado ao currículo, legibilidade e inteligibilidade apropriados ao público-alvo; subdivisão da obra em partes, como texto propriamente dito, boxes, resumos, glossário, bibliografia, atividades e exercícios etc., segundo uma estrutura de organização adequada à aprendizagem; e, sobretudo, subordinação do estilo do texto e da arte gráfica a esse objetivo de servir de instrumento auxiliar de ensino/aprendizagem. (MUNAKATA, 1997, p. 100)

Embora sejam um caminho para se chegar à chamada cultura letrada, ou partam de algum grau dela para adentrar áreas específicas do conhecimento, esses livros se diferenciam visualmente das obras típicas que caracterizam a cultura letrada já conquistada e estabelecida. Ou seja, aquelas cujas páginas são preenchidas unicamente com texto corrido. 


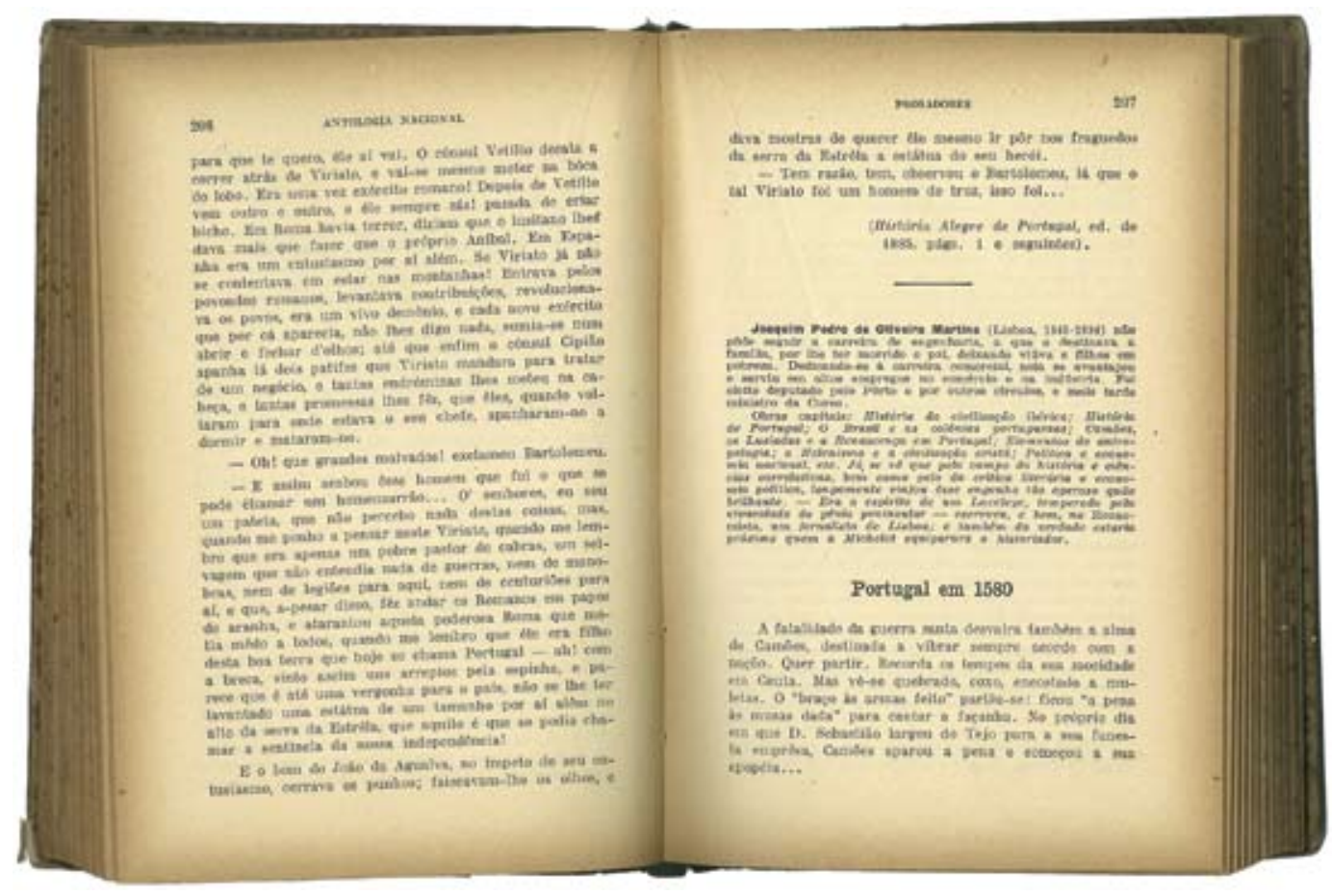

Mesmo as coletâneas já apresentam uma interrupção no texto densamente composto, com introduções, comentários e questões que evidenciam graficamente sua finalidade didática. As cartilhas ilustradas vão bem mais longe em sua liberdade com a composição tipográfica convencional, denotando a tentativa de se produzirem meios que permitam ao aprendiz chegar à aquisição da escrita e da leitura. E, se as páginas de obras de Geometria não podem prescindir de construções gráficas, as de Geografia ou Ciências procuram reproduzir o que se observa na natureza para ilustrar ou mesmo chegar aos conceitos expressos no texto escrito. E as de História procuram fornecer alguma contextualização ou imagens de seus personagens como recurso para facilitar a apreensão dos conhecimentos ou valores veiculados. De qualquer maneira, visualmente não há como confundir uma obra escolar com outra que não apresente esse compromisso ou finalidade.

\subsection{A página (apenas) de texto}

A estrutura visual do livro formado apenas por texto composto parece bastante comum, estamos acostumados a ela porque constitui a forma da grande maioria dos livros e gêneros que conhecemos, dos romances aos livros de autoajuda, dos ensaios às obras de divulgação científica e até de parte dos livros escolares mais antigos ou atuais voltados para os cursos superiores. O que ela contém de informação parece que se restringe apenas à sequência de palavras que precisaremos ler para extrair os significados.

Mas a página cheia de texto que achamos tão natural que não conseguimos imaginar que pudesse ser diferente para determinados conteúdos foi construída pela história e por isso já nos diz algumas coisas antes da leitura que faremos dos caracteres nela impressos.
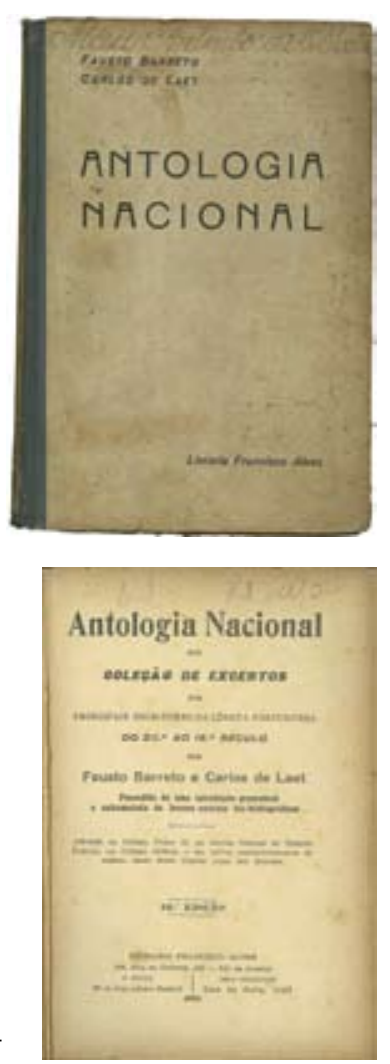

Páginas, capa e rosto da Antologia Nacional, de Carlos de Laet e Fausto Barreto. 19. ed., 1934, Francisco Alves (1. ed., Paulo de Azevedo, 1895). Apresentava ordem cronológica inversa, do período contemporâneo ao medieval, notícias biobibliográficas antes do primeiro excerto de cada autor e notas explicativas (estas apenas após a 25. ed., de 1945). ${ }^{9}$

9 Um estudo rico e completo dessa obra e sua importância para a afirmação da nacionalidade, bem como as características e autores das várias edições em sua relação com o ensino da língua e da literatura nos vários períodos da educação no Brasil é feito por Márcia Razzini em sua tese de doutorado 0 espelho da nação: a Antologia Nacional e o ensino de português e de literatura (1838-1971), já mencionada na Introdução. 
$10 \mathrm{Na}$ verdade, a neutralidade e regularidade do texto impresso determinadas por seu processo tecnológico seriam um aprofundamento de uma tendência contida na própria escrita desde suas origens. Para Pierre Lévy, a escrita rompe a circularidade do tempo mítico das culturas orais e instaura 0 tempo histórico, linear, as noções de passado, presente e futuro. 0 registro escrito distancia os momentos e as condições concretas da redação e da leitura de um texto e com ele surge também a construção de discursos que bastam a si mesmos, de caráter universal e atemporal, o chamado conhecimento teórico. $\mathrm{Na}$ forma impressa, a escrita parece adquirir uma neutralidade ideal para o registro indiferenciado de narrativas $e$ conhecimentos de diversas origens, campos, enfoques e intenções, reforçando a potencialidade da escrita em geral de separar as circunstâncias em que os discursos são produzidos das circunstâncias de sua recepção e apresentar as ideias em sua suposta pureza.
A primeira coisa que nos é comunicada é que, diferentemente de uma revista ilustrada ou de um livro escolar, essa página com apenas texto traz a marca da cultura letrada no sentido mais pleno. Parece óbvio e coisa de pouca importância, mas com a expansão da imprensa de massa no século XIX sob diferentes modalidades — jornais e revistas ilustrados e principalmente o início da presença da publicidade que os acompanhava - esse caráter de repositório da alta cultura literária e principalmente da cultura humanística foi num primeiro momento bastante reforçado e transformado numa marca de distinção social. Com o desenvolvimento da indústria cultural e a criação de gêneros literários populares, paralelamente à alfabetização como conquista social das massas, esse caráter da página composta como veículo exclusivo da alta cultura pode ter sido em parte diminuído, mas ainda hoje, para muitos segmentos da população, mesmo ler livros de autoajuda e romances ligeiros é marca de distinção cultural e social em relação a quem não tem acesso a eles ou não tem o hábito de leitura.

A esse significado primeiro que uma simples página de texto comunica visualmente outros podem ser acrescentados, conforme as variações formais possíveis dentro desse esquema básico. Uma página muito densa, com texto composto em corpo pequeno, pouca margem e espaço pequeno entre as linhas, antes que uma questão de economia ou equívoco técnico pelas dificuldades que impõe pode ser eficaz do ponto de vista de algo também importante que pretende comunicar, a autoridade do autor e a importância e transcendência de seu conteúdo, que estimula o leitor especializado e treinado a enfrentá-lo como um desafio que valorizará seu esforço, ao mesmo tempo que infunde o respeito naqueles que nunca o lerão.

Ávidos pelas narrativas, raciocínios e imagens poéticas resultantes da leitura como sequência de palavras formadas por letras e formando frases e períodos, não nos damos conta da visualidade e materialidade dessa página de texto. Na verdade ela nos parece invisível como forma, transparente, e geralmente é bom que assim seja. Afinal, queremos viajar nas palavras, de preferência elevados do solo, e não tropeçar em letras, manchas, texturas e outras pedras encontradas pelo caminho. Mas, para que essa nossa viagem tranquila aconteça, é preciso que alguém veja primeiro que nós esses materiais, escolha os mais adequados e os organize visualmente. Esse alguém é sempre uma pessoa real com um treino e habilidade específicos, mas o que interessa nesse momento é a existência na cultura, ou na nossa cultura, desse tipo de página, e o significado que ela contém e transmite. Primeiro de tudo, a própria eficiência e favorecimento da leitura que essa página parece oferecer e que implica um trabalho técnico para obtê-la é também um significado cultural, um fato da cultura. ${ }^{10}$

No caso de muitos livros escolares do final do século XIX e começo do XX no Brasil, mesmo que dirigidos a crianças em fase de alfabetização ou recém-alfabetizadas, essa configuração de página os inscreve no universo da cultura letrada, que faz com que o próprio processo de adquiri-la não pressuponha nenhuma facilitação através de uma organização visual especial e mais amigável. A escola ainda era para poucos e a educação era coisa séria a ser obtida arduamente, que o diga 
Graciliano Ramos. Como parte dessa cultura transmitida pelo texto, a invisibilidade de sua forma era também um pressuposto.

Mesmo destinada apenas à leitura de seu conteúdo linguístico e despojada de imagens ou elementos gráficos, a página de texto composto é antes de tudo

e sempre visual. $O$ texto é formado por letras que têm determinada estrutura construtiva, com relações entre os vazios e os cheios que as tornam mais pesadas ou mais leves, com inclinações ou orientação vertical mais acentuada que induzem a maior ou menor velocidade de movimento dos olhos na leitura, com características plásticas que as relacionam a períodos históricos ou áreas de conhecimento. Mesmo uma pretendida neutralidade não deixa de corresponder a um estado de espírito e predisposição psicológica, e, como já dissemos, encarna um significado cultural fundante das sociedades ocidentais, a autoridade do texto escrito.

As linhas que elas, letras, formam podem estar mais afastadas, individualizando-se como tais e marcando um determinado ritmo; ou juntas, reforçando a qualidade de superfície do texto impresso. Além das linhas de texto, outras linhas são também vistas - as quatro formadas pelos limites laterais e superior e inferior das linhas de texto, que podem ser mais definidas, conforme a distância entre as linhas, ou mais quebradas e interrompidas, conforme as dimensões dos parágrafos, impondo uma percepção de ritmo variado ou um pulso regular. A superfície resultante da reunião das linhas pode ser mais densa, mais escura ou clara, de tonalidade homogênea, ou irregular e manchada, conforme a concentração de determinados caracteres e palavras. E essa superfície está dentro de outra, a folha de papel, com o inevitável estabelecimento de uma relação de posicionamento e proporção entre ambas, ou melhor, entre duas manchas de texto - e o termo "mancha" não esconde seu significado visual - e uma superfície maior formada pela páginas direita e esquerda do livro aberto, complexizando essas relações compositivas. O papel também possui sua textura, seus valores táteis, e a cor da tinta, bem como a carga de impressão, estabelecem diversos graus de contraste entre ambas as superfícies com efeitos plásticos e perceptivos diferentes. A impressão tipográfica, além de depositar a tinta, marca o papel e dá textura e relevo à página, percebidas pelo tato e pela vista.

Voltando à questão do desenho das letras, aqui também se manifesta a autonomia da linguagem visual e suas "leis" e da cultura plástica em relação à cultura escrita. Ou seja, mesmo a serviço da construção da forma dos signos do próprio código da linguagem verbal, da cultura escrita, são as necessidades e processos de criação próprios da forma a ser percebida visualmente o que determina a construção plástica das letras. Assim, o desenho de tipos foi, e é, uma atividade bastante especializada, que reúne conhecimentos de forma e julgamento visual, de técnicas de reprodução, suportes, meios e tintas.

Cada fonte tipográfica apresenta um desenho característico e é um produto não só do talento e trabalho de seu criador, mas também da tradição que o antecedeu, da cultura em que foi produzido e de determinadas necessidades e intenções. Cada um dos grandes desenhos de fontes já produzidos em primeiro lugar preserva conscenciosamente a tradição da escrita romana (no caso ocidental) pelas 
necessidades de transmitir um código que não pode ser modificado sob risco de instaurar a arbitrariedade na comunicação e em última instância a destruição da própria cultura, e, no entanto, inova e refresca a tradição. Tanto quanto as escritas cursivas anteriores à imprensa revelam sua época, as fontes tipográficas são nitidamente reconhecidas como renascentistas, barrocas, neoclássicas, românticas, modernas, pós-modernas, enfim, se alinham formal e espiritualmente com a cultura que as produziu, mesmo aquelas que em cada um desses momentos buscasse a neutralidade e invisibilidade. E embora seus criadores possam ter buscado desenvolvê-las com critérios de adequação às características da língua a que serviriam - ocorrência maior de determinadas letras, predomínio de ascendentes, descendentes ou maiúsculas, etc. - e aos meios de reprodução e características do suporte e das tintas, buscando a maior regularidade possível para não tirar a atenção do conteúdo a ser lido, eles o fizeram informados pelo ambiente cultural em que viviam, informando-o também e tornando sua criação parte dessa cultura.

Todos os elementos e configurações materiais e plásticas presentes na simples página de texto certamente informam alguma coisa isoladamente, mas na verdade aparecem combinados e sua percepção se dá pela totalidade dos efeitos dessa combinação. E antes da leitura linguística se realizar já estão a enviar mensagens que nosso sistema cognitivo trata de decodificar, numa velocidade infinitamente mais rápida que a da leitura linear — feita da direita para a esquerda e de cima para baixo - que buscamos na decodificação do código linguístico. Essas mensagens certamente são de natureza e complexidade diferentes da mensagem escrita e uma não se reduz nem traduz a outra. No entanto, os dois modos de elaboração e transmissão de mensagens, o visual e o linguístico, comparecem juntos na construção de significados propostos pela página impressa.

Um mesmo original, editado de maneiras diferentes quanto a formato, desenho das letras, ocupação da mancha, paginação, resultará em livros diferentes, pois passará ideias diferentes de seu conteúdo e certamente será destinado a públicos diferentes.

Numa página com desenho mais complexo, que combina texto, imagens e outros elementos gráficos, parece mais evidente seu caráter visual e que sua leitura não é exclusivamente linguística. Como são grandes as possibilidades de combinação bem como a variedade e as características que pode ter cada elemento desenho das letras, estilos das ilustrações e fotografias, uso de cores, organização espacial etc. - , a possibilidade de significados comunicados visualmente parece ser bem maior, e efetivamente é. Por exemplo, o arranjo de elementos que identificam uma publicação com um grupo de leitores com interesses comuns, ou o que predispõe afetivamente para a leitura, criando o "clima" ou o "cenário gráfico" para a recepção do conteúdo textual que será lido. Enfim, aqui também, conteúdos são transmitidos antes da leitura propriamente linguística.

Aqui cabe um paralelo com o texto falado: este nunca é estritamente verbal, mas é também visual, pois combina expressão facial, gestos e posturas corporais, que também comunicam conteúdos independentemente do que está sendo transmitido pelas palavras. Mais ainda, o próprio suporte sonoro das palavras co- 
munica conteúdos independentes delas próprias, dados pelo tom e volume da voz, timbres e inflexões, ritmos e ênfases, a tal ponto que é comum perceberem-se contradições entre um e outro, quando o discurso linguístico estrito afirma uma coisa e seu suporte sonoro e gestual indica outra.

Já vimos que o texto escrito tem também um forte componente visual: é composto com fontes tipográficas com desenho originado de considerações estéticas, psicológicas e pragmáticas e impresso em algum material, com determinado formato e com determinada ocupação desse formato. E também podemos acrescentar que esse componente visual pode veicular até conteúdos atribuídos ao modo auditivo/sonoro, quando se diz que uma página ou peça gráfica comporta um tom ou voz visual para uma mensagem, e os conteúdos comunicados por essa voz também precisam estar adequados ao conteúdo linguístico sob risco deste ser contradito pelos primeiros. Essa associação entre diversos modos ou suportes de comunicação não é simplesmente uma metáfora feliz, mas revela a multimo-

dalidade envolvida nas mais diversas manifestações da comunicação humana"1. No entanto, no que tange ao texto escrito e impresso, essa multimodalidade muitas vezes foi e é largamente ignorada, como poderemos constatar no tratamento dado a miolos e capas de livros escolares.

Os elementos ou materiais que constroem a visualidade de uma página (e de uma capa, um quadro, uma fotografia ou uma escultura) são articulados segundo "lógicas" e procedimentos próprios do modo visual e seus materiais, diferentes da lógica e dos procedimentos próprios do modo linguístico. Assim, a leitura de um título, de uma legenda ou de um bloco de texto seguirá o procedimento da leitura ocidental, no nosso caso, da esquerda para a direita e de cima para baixo, e seu significado será obtido pelas regras da gramática que relacionam atributos e ações a sujeitos, segundo determinados procedimentos e não outros. Mas o momento e a sequência em que a leitura desse texto terá início, se antes ou depois de outros textos ou da percepção de outros elementos, e a importância e o significado que seu posicionamento e relação com os outros materiais gráficos transmitirão serão determinados por outro tipo de "gramática", o da linguagem visual12. Ou seja, tanto como uma forma em uma pintura abstrata, o todo poderoso texto, na página ou numa peça de comunicação, é mais um elemento gráfico e se submete à "lógica" da composição visual e aos significados que ela, e só ela, é capaz de construir.

Isto ocorre porque, enquanto conteúdos veiculados pela escrita são acessados por um processo temporal mais lento, baseado na leitura sequencial e condicionada de unidades de significado dispostas linearmente, conteúdos veiculados visualmente são acessados de maneira muito mais rápida, segundo trajetos do olhar mais flexíveis propostos pelos contrastes e relações espaciais presentes em cada caso concreto que o visualizador tem diante dos olhos. Essa característica holística, mais espacial que temporal, da percepção visual, reconhecida empiricamente pelo senso comum e estudada pela psicologia cognitiva, justamente é responsável pela percepção de conteúdos decisivos para a decodificação de mensagens e construção de significados. Como o componente visual de uma mensagem chega primeiro ao cérebro, este pode reagir muito imediata e desfavoravelmente caso
11 Peter BONNICl, em Visual Language: The hidden medium of communication, investiga e apresenta de maneira bastante didática a noção de voz visual.

12 KRESS; LEEUWEN (cit., p. 20) admitem o empréstimo desse termo da linguística apenas no sentido de que tanto como as mensagens escritas, as manifestações imagéticas apresentam algumas "regularidades" formais associadas a alguns sentidos socialmente codificados dentro de uma cultura, nunca como uma equivalência entre os processos internos de construção das mensagens dos dois modos. Ou, como pode ser visto em SANTAELLA \& NOTH, 1999, p. 50-51, ao contrário da sintaxe verbal, que articula através de regras preestabelecidas um repertório de unidades mínimas com valor de oposição (fonemas), uma sintaxe visual não existe a priori, mas se estabelece em cada manifestação particular. Ou seja, se há algum valor funcional nos elementos que formam uma imagem (formas, cores, etc.), ele é contextual, pois só pode ser deduzido a partir da imagem percebida como totalidade. Em outras palavras, cada imagem estabelece sua própria sintaxe. 


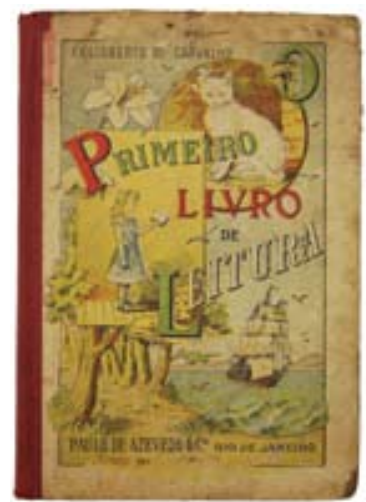

Páginas do Primeiro Livro de Leitura, de Felisberto de Carvalho. 109. ed. 1926. Desenhado e refundido por Epaminondas de Carvalho. Paulo de Azevedo/Francisco Alves.

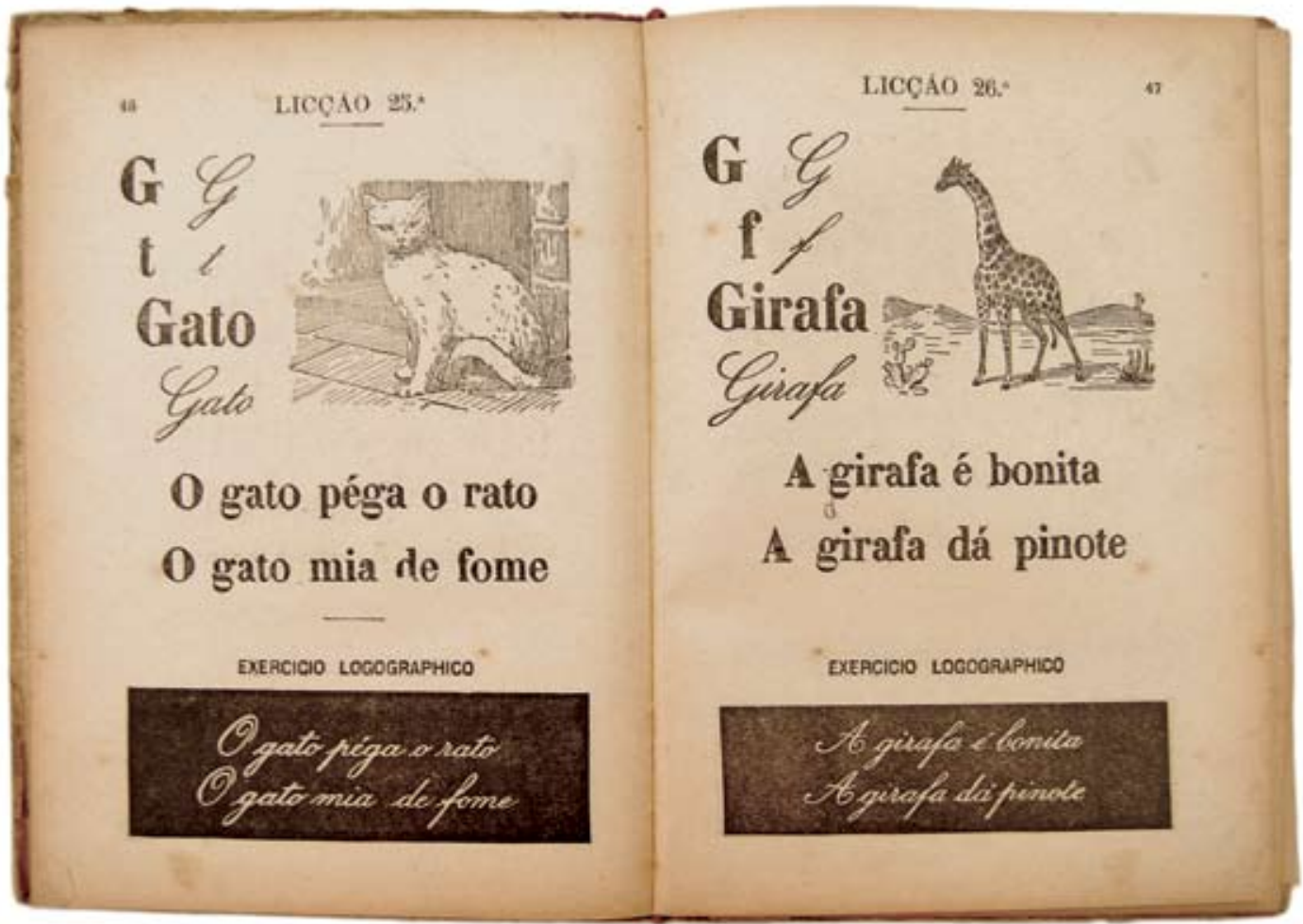

o componente linguístico não esteja perfeitamente combinado com o primeiro, não aderindo à mensagem pretendida ou nem sequer a compreendendo. Ou o contrário, quando a mensagem é coerentemente construída, com pleno domínio dos materiais e procedimentos do modo em questão, a construção do sentido é realizada plenamente.

Cada um dos modos, o visual e o linguístico, permite a veiculação de tipos próprios de conteúdos, decorrente da natureza material de seus próprios significantes. Alguns desses conteúdos podem ser parcialmente traduzidos para outros, com perda maior ou menor da precisão ou potência comunicativa. Outros são irredutíveis, sem área de intersecção. Mas os significados, ou sentidos, que esses conteúdos produzem não são exclusivos de cada modo em si, mas pertencem a quem os produz e utiliza, pessoas concretas em épocas e sociedades concretas. Ou seja, os significados são antes de tudo sociais e produtos de uma cultura, mesmo sendo veiculados e se manifestando em modos de expressão diferentes. E cada sociedade e contexto particular valoriza ou elege algum desses modos em detrimento de outros, como podemos ver no caso da milenar valorização do modo verbal e escrito em detrimento do visual nas sociedades ocidentais e mais ainda na sociedade e escola brasileira nos séculos XIX e XX com reflexos até o momento atual, mas, no que nos interessa, com reflexos na configuração do livro escolar, como veremos adiante. 


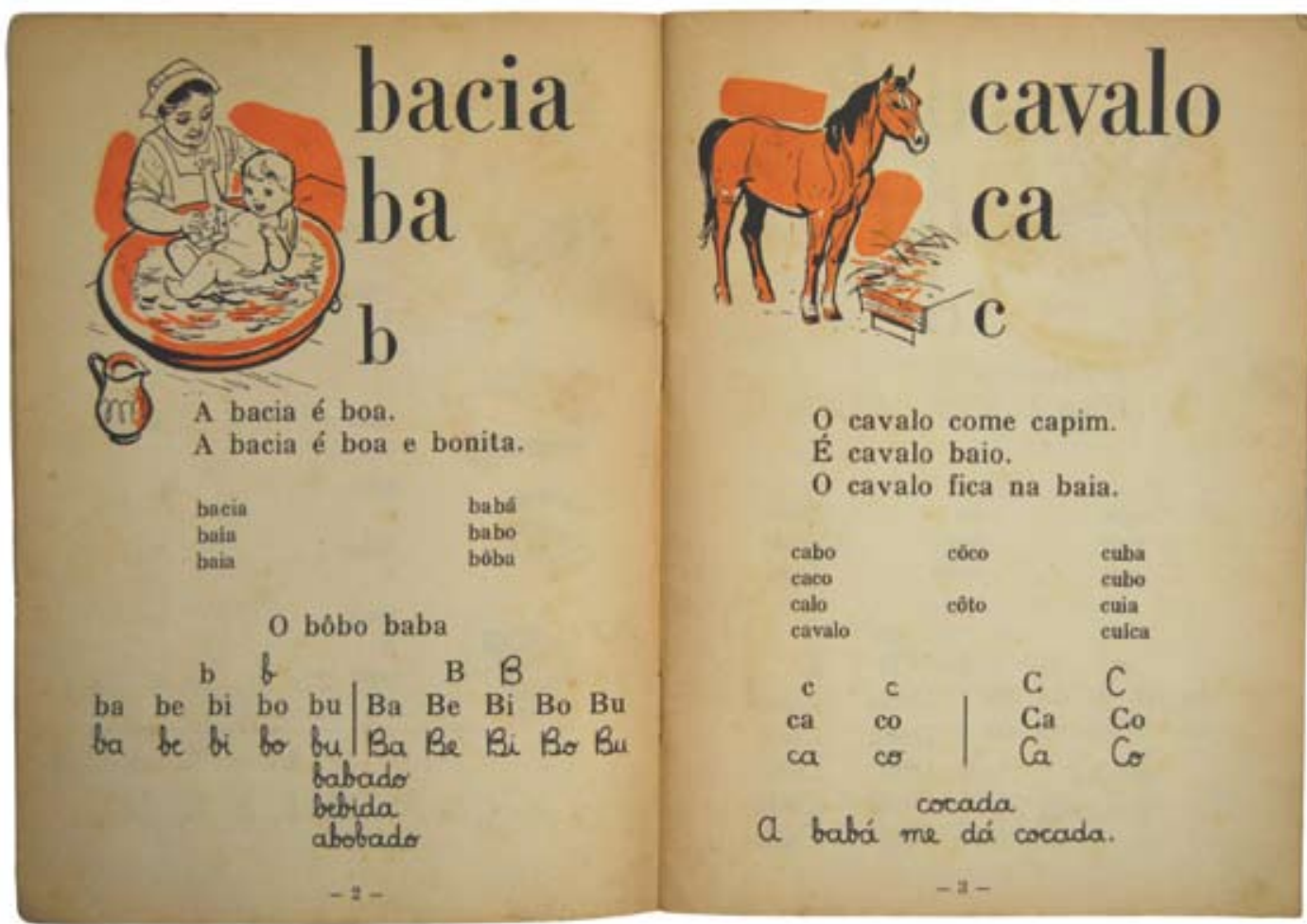

\subsection{A página do livro escolar}

É aqui que podemos voltar para nossas páginas de texto, ou de texto e imagens, e os significados que elas podem veicular. As várias configurações que elas tomam isoladamente e, mais ainda, em sua organização sequencial e como objeto integral livro, incorporando sua capa, que merecerá destaque em nossa análise, não são arbitrárias como forma e como significado. Produzidas numa época determinada, por pessoas e instituições com intenções determinadas, utilizarão os meios materiais disponíveis naquele dado momento, transformados em meios semióticos, isto é, de construção de sentidos.

Em contraposição à página de "texto corrido" e seu significado básico de representação visual da cultura letrada plena, apresentou-se o exemplo da antologia de textos e citou-se o de cartilhas como portadores de significado visual relacionado ao uso didático em direção a essa cultura, o que marcaria o caráter instrumental do livro didático. No caso das cartilhas, a presença de ilustrações é uma marca inequívoca dessa particularidade do livro escolar e atesta sua "vocação visual".

Em ambas as cartilhas reproduzidas, as ilustrações procuram ser "realistas" e "objetivas" e, em princípio, representar seres e objetos conhecidos dos pequenos aprendizes para estabelecer uma relação estreita de esclarecimento do significado das sílabas e palavras ensinadas. Supondo que as imagens, pelo seu poder próprio de atração, são vistas em primeiro lugar, principalmente no caso de uma criança ainda não alfabetizada, a ordem em que elas aparecem em relação às palavras não teria muita importância do ponto de vista funcional e as duas cartilhas seriam equivalentes nesse aspecto.

No entanto, quando na cartilha de Felisberto de Carvalho um ser ou objeto

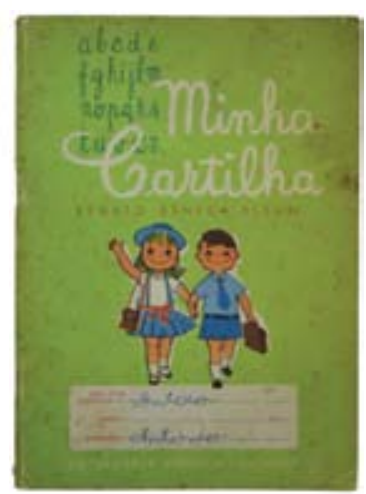

Páginas da Minha Cartilha, de Renato Sêneca Fleury. 37. ed. Nacional, 1961. 
desconhecido de uma criança de 7 anos é apresentado, parece que, ao invés de a imagem ser ponto de partida para se chegar ao texto, como pretende o autor, é este que prevalece e a imagem se torna uma ilustração dele.

Já na cartilha de Renato Sêneca Fleury, a ilustração aparece à esquerda, seguida do grupo verbal, que começa com a palavra inteira e vai para a sílaba e a letra. Seguindo a ordem de leitura ocidental, que se aplica também no reconhecimento do campo visual, vemos primeiro a imagem, que não só tem um poder de atração em relação ao texto mas também se localiza no ponto de partida do movimento visual ${ }^{13}$. Assim, fica reforçado o sentido dado à imagem de conhecido, familiar, a partir do qual o movimento do olho vai na direção do novo, do desconhecido, o texto, mostrando que a posição desses elementos não é indiferente. E que talvez a organização visual da cartilha de Felisberto Carvalho acabe por trair a subserviência do visual ao verbal dominante na época.

Com relação às imagens da cartilha de Renato Fleury, é claro que a ilustração do vocábulo bacia não é nem um pouco "objetiva" e transparente, porque há pelo menos três coisas representadas na ilustração, para uma única palavra, enquanto que no vocábulo cavalo a relação é unívoca e, portanto, mais clara.

Ainda sobre a "objetividade" da representação, nos dois casos o simples caráter icônico, figurativo das imagens não garante a compreensão, pois se trata sempre de representação de algo obviamente ausente, o que implica uma "tradução" para outro suporte, através de meios e recursos que constituem uma linguagem, implicando, portanto, um código. Nem uma fotografia seria completamente objetiva, pois implica um aprendizado de reconhecimento do meio e de sua linguagem. $\mathrm{O}$ que dizer de linhas irregulares e interrompidas e manchas pretas e laranja, uma única cor, num plano, para evocar o tridimensional e o multicolorido? Há um código que talvez não seja tão imediatamente reconhecido e significativo para crianças de 6 a 7 anos da década de 1960 e que precisa ser adquirido, o que pode ocorrer com o uso da própria cartilha e principalmente com a presença do professor.

Mas outras configurações de páginas de livros didáticos podem revelá-las como arranjos antes de tudo visuais que informam significados culturais e sociais antes mesmo de sua leitura.

O primeiro exemplo é o do livro que apresenta texto ilustrado por imagens quando estas não acrescentam nenhuma informação ao que aquele já expôs. Na verdade, sempre alguma informação está sendo acrescentada, pois a imagem apresenta de outro modo o que foi dito, com sua linguagem própria, que em si informa outras coisas além do informado pelo texto. Mas o que se quer dizer é que a ilustração aparece como secundária em relação à importância do texto, pois não contribui para estender seu significado nem para facilitar seu entendimento, apresentando uma redundância, do ponto de vista do significado, que dispensaria sua presença. Esta situação expressaria o grau extremo da chamada "autoridade do discurso" (Barthes apud KRESS; LEEUWEN, cit., p. 18-19). Nesta relação, textos ver-

13 Esta é uma das "regularidades" mencionadas por Kress e Leeuwen encontradas na comunicação visual e na arte ocidental. bais — os textos fundadores da cultura, como a Bíblia — são a fonte de autoridade da sociedade, e as imagens elaboram esses textos e os disseminam no modo visual para os grupos não letrados (fazendo com que paradoxalmente as imagens sejam 


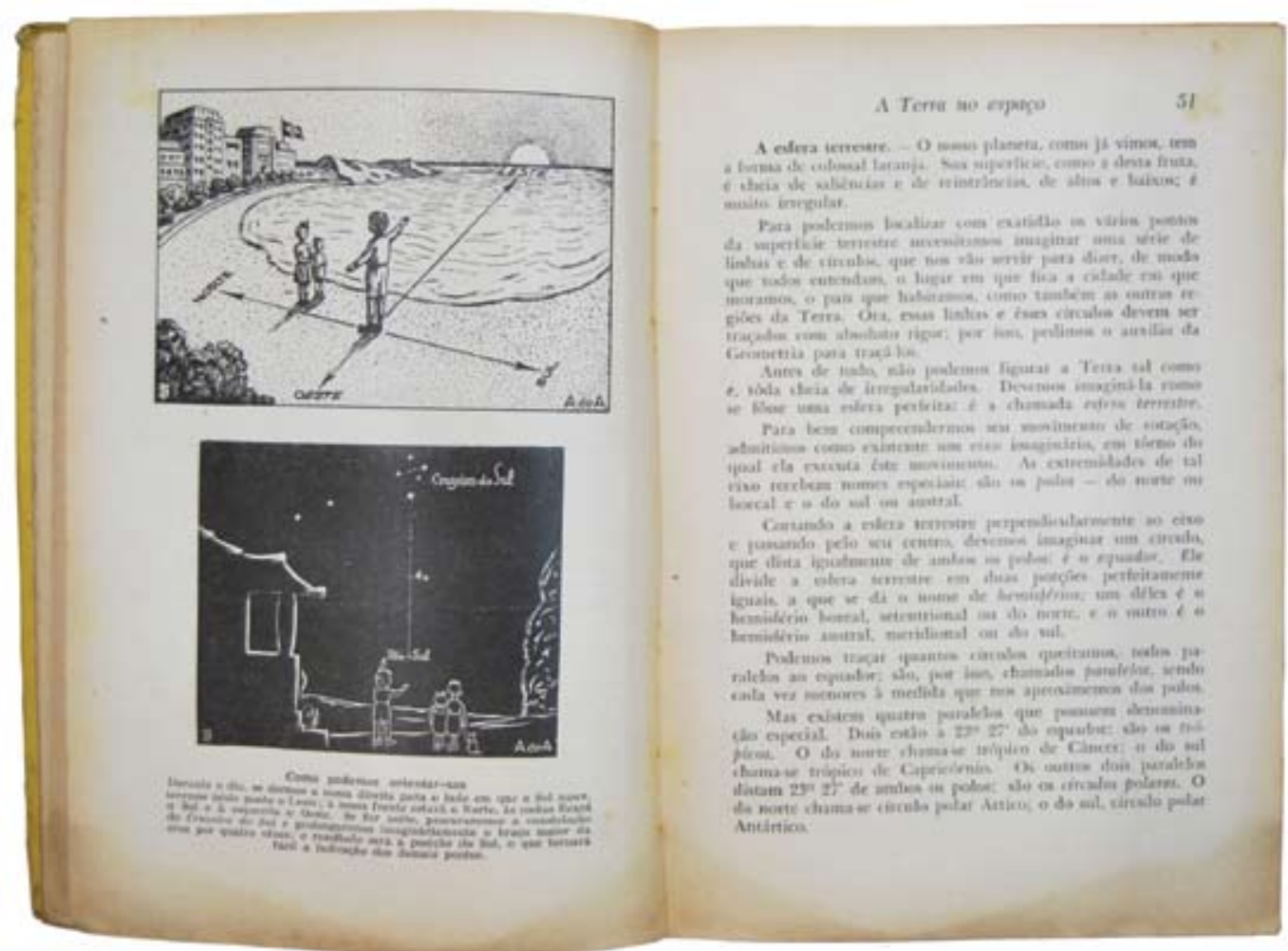

dominantes). Mas, num livro ilustrado dessa forma, o texto comanda e controla a imagem, que é uma ilustração dele. ${ }^{14}$

Já as páginas da obra de Aroldo de Azevedo contêm ilustrações, gráfico, fotografias e mapas. Por veicular conteúdo de uma disciplina científica, a obra inscreve-se numa outra tradição, que foi gradualmente substituindo a anterior, a da "autoridade da natureza", em que o mundo é primeiro visto, para então ser analisado pelos instrumentos da ciência e interpretado na forma de textos. Há uma valorização da imagem, que reproduz o mundo da maneira mais naturalista possível, e é o texto verbal que a reelabora e completa. Essa tradição se inicia com o desenvolvimento das ciências a partir do século XVII e vai configurar páginas como as do que é considerado o primeiro livro didático para crianças — Orbis Sensualium Pictus $(O$ mundo visível em imagens), de Comenius. Publicado em 1658, apresentava imagens seguidas de texto em vernáculo (alemão) e latim, servindo para instruir sobre os assuntos tratados e ensinar a língua universal. No ano seguinte já foi editado em inglês e latim, e em 1666 surgiu uma edição quadrilíngue (latim, alemão, francês e italiano), sendo seguida de inúmeras outras.

Nesse que foi o precursor do uso de imagens no ensino e modelo para o livro didático moderno, as ilustrações são decisivas para apresentar o conhecimento e os objetos e de fato determinam e dirigem o texto. Essa relação texto-imagem expressa um novo regime de visualidade estabelecido pela ciência criada a partir do Renascimento. E corresponde às ideias humanistas de Comenius, homem da igreja e da ciência, que funda a didática moderna com os princípios da educação pública universal, explicitados em sua obra Didactica Magna - Tratado universal de ensinar tudo a todos, publicada em 1679. Nessa obra, além de princípios pedagógicos, defesa do direito à educação e normas de funcionamento das escolas, até hoje não

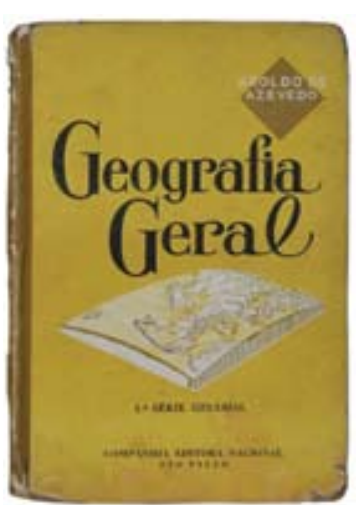

Páginas de Geografia Geral, de Aroldo de Azevedo. 1. a série ginasial. 84. ed. Nacional, 1955.
14 Sobre as possíveis relações entre imagem e texto — redundância, informatividade, complementaridade e discrepância — ver SANTAELLA; NOTH, 1999, p. 54-55. Nessas páginas, os autores apresentam também as formas de referência recíproca entre imagem e texto elaboradas por Barthes. 

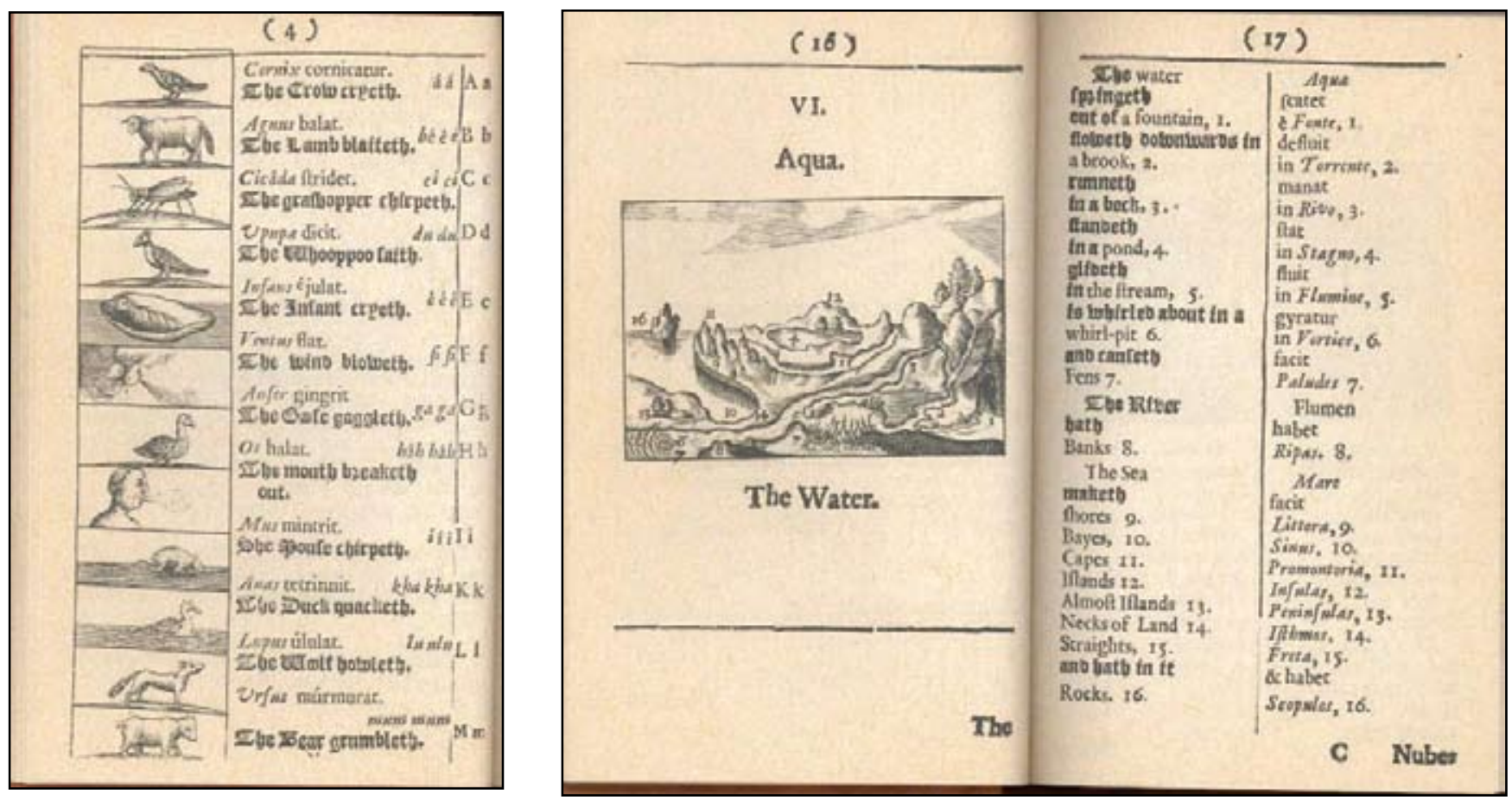

Jan Comenius. Orbis Sensualium Pictus. Páginas da edição inglesa de 1659. superados em seu sentido essencial, Comenius estipula que o meio mais adequado para ensinar a ler é a utilização de um livro que combine leituras adaptadas a cada idade com imagens.

Num terceiro tipo de página, já contemporâneo, a relação texto-imagem parece bem mais complexa. O texto, no livro didático, há muito já não flui como um continuum e não só é quebrado em blocos que recebem títulos intermediários, mas também apresenta seções e boxes para leitura paralela ou complementar. Hoje, parte do conteúdo é exposta em páginas em que o texto apresenta uma relação de equivalência e interação com as imagens. Nos infográficos, cada um dos modos de expressão é usado em sua potencialidade máxima, e o resultado comunicativo se apoia nessa complementaridade. Em alguns livros, o leitor pode ter vários pontos de entrada na página, ao contrário da página tradicional. Essa organização afasta o livro do aspecto de tratado científico e ressalta ainda mais o seu caráter de uso voltado para a transmissão da informação considerada essencial. O resultado é uma estrutura visual aparentemente mais complexa, o que corresponde a outro momento da educação e da cultura de massas no país, em que os meios audiovisuais e a presença do computador pessoal e da internet se fizeram dominantes e fornecem modelos e a chave para sua compreensão, como é o caso da representação simultânea de vários momentos de um fato.

Esse confronto entre poucos exemplos de páginas de livros escolares de períodos e disciplinas diferentes é intencionalmente sumário, servindo apenas para mostrar alguns aspectos da relação entre visualidade e significados culturais que ela pode encarnar. Se os poucos elementos encontrados numa página, até mesmo naquelas em que o texto é dominante, permitem vê-la também como fenômeno perceptivo visual, nas capas — tema deste trabalho - a autonomia da linguagem visual para a construção de sentido ficará mais evidente. 


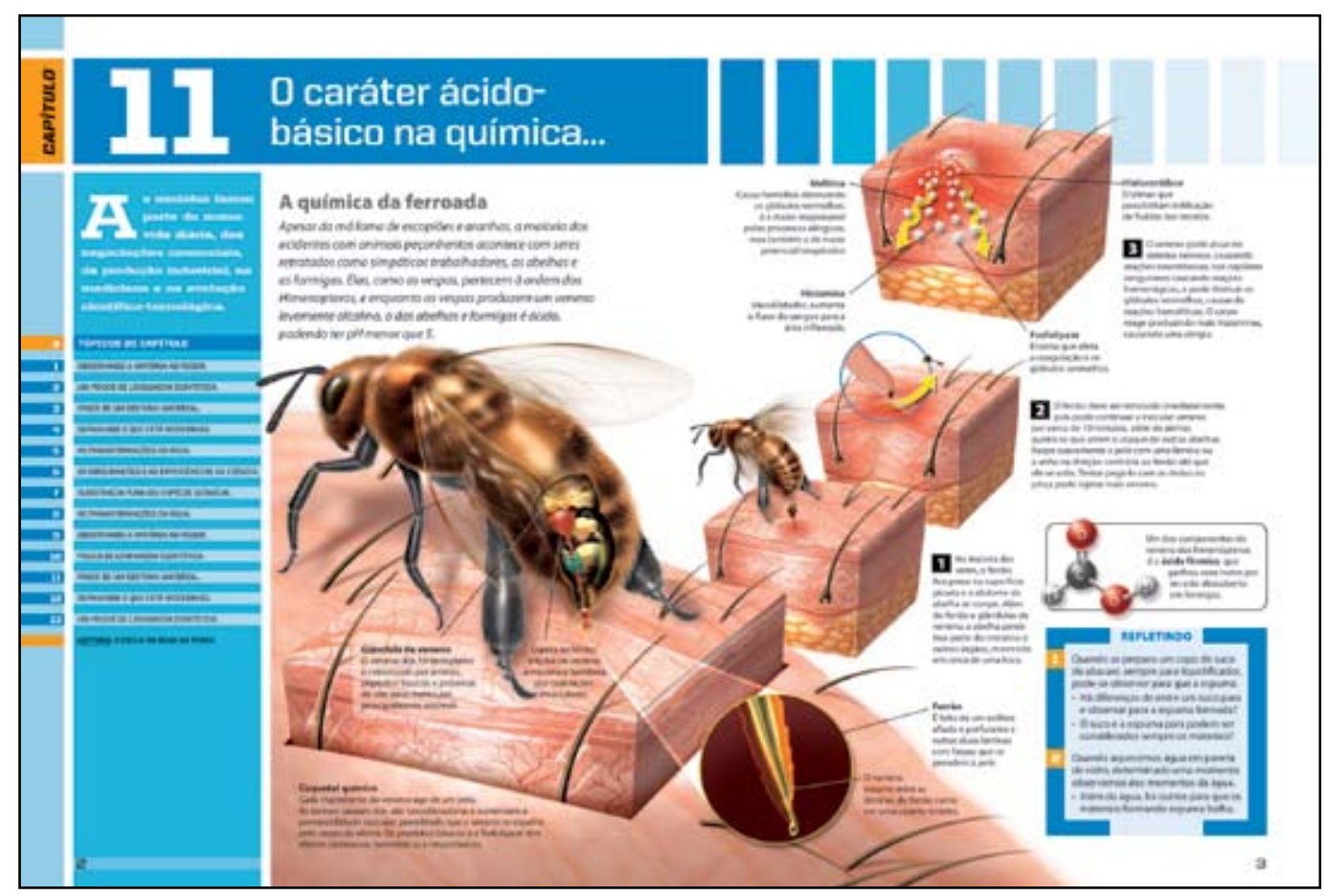

\subsection{A tradição visual do livro didático brasileiro}

Marisa Lajolo e Regina Zilberman (1999, p. 120-121) caracterizam o livro didático brasileiro como "primo pobre da literatura" e "primo rico das editoras". No primeiro caso, devido a seu caráter de uso descartável e datado, de conteúdo sempre reduzido e superado em relação ao conhecimento científico; no segundo, pelos lucros certos que propiciava.

Um exemplo do lugar ocupado pelo livro didático na história da indústria livreira geral do país, particularmente seu papel na economia dessas empresas, é o da Editora Francisco Alves, fundada em 1897. Para seu titular, literatura era o "Osso" e didáticos, a "carne":

Os livros didáticos constituem uma linha de vendas segura e permanente, além de proporcionar ao editor nacional uma vantagem sobre os competidores estrangeiros, cujos produtos jamais podem adaptar-se tão bem às condições ou aos currículos locais. Por isso, Baptiste Louis Garnier já tinha iniciado a publicação de livros didáticos (\$64), mas Francisco Alves foi o primeiro editor brasileiro a fazer dessa linha editorial o principal esteio de seu negócio. (HALLEWELL, cit., p. 280)

Para Monteiro Lobato:, que fundou a Editora Nacional em 1925:

"O bom negócio é o didático. Todos os editores começam com a literatura geral e por fim se fecham na didática. Veja o Alves". (HALLEWELL, cit., p. 337)

O desenvolvimento da literatura didática acompanha o próprio desenvolvimento do ensino e da educação no país. Assim, o êxito da Francisco Alves foi coincidente com a expansão do ensino primário após 1888 (HALLEWELL, cit., p. 280) e o crescimento inicial da Nacional se deu paralelamente ao desenvolvimento do ensino secundário e sua modernização pela reforma Campos de 1931 (HALLEWELL, cit., p. 367), levando-a a suplantar a Francisco Alves na década de 1950.
Química.v. 3: Química Orgânica. Ricardo Feltre. São Paulo, Moderna, 2008. 7. ed. Edição de texto: Ronaldo Rocha, Ricardo Arissa. Edição de arte: Fernanda Fencz. Edição de infografia: William Taciro. Ilustração: Erika Onodera. Infografia: A+ Comunicação. 

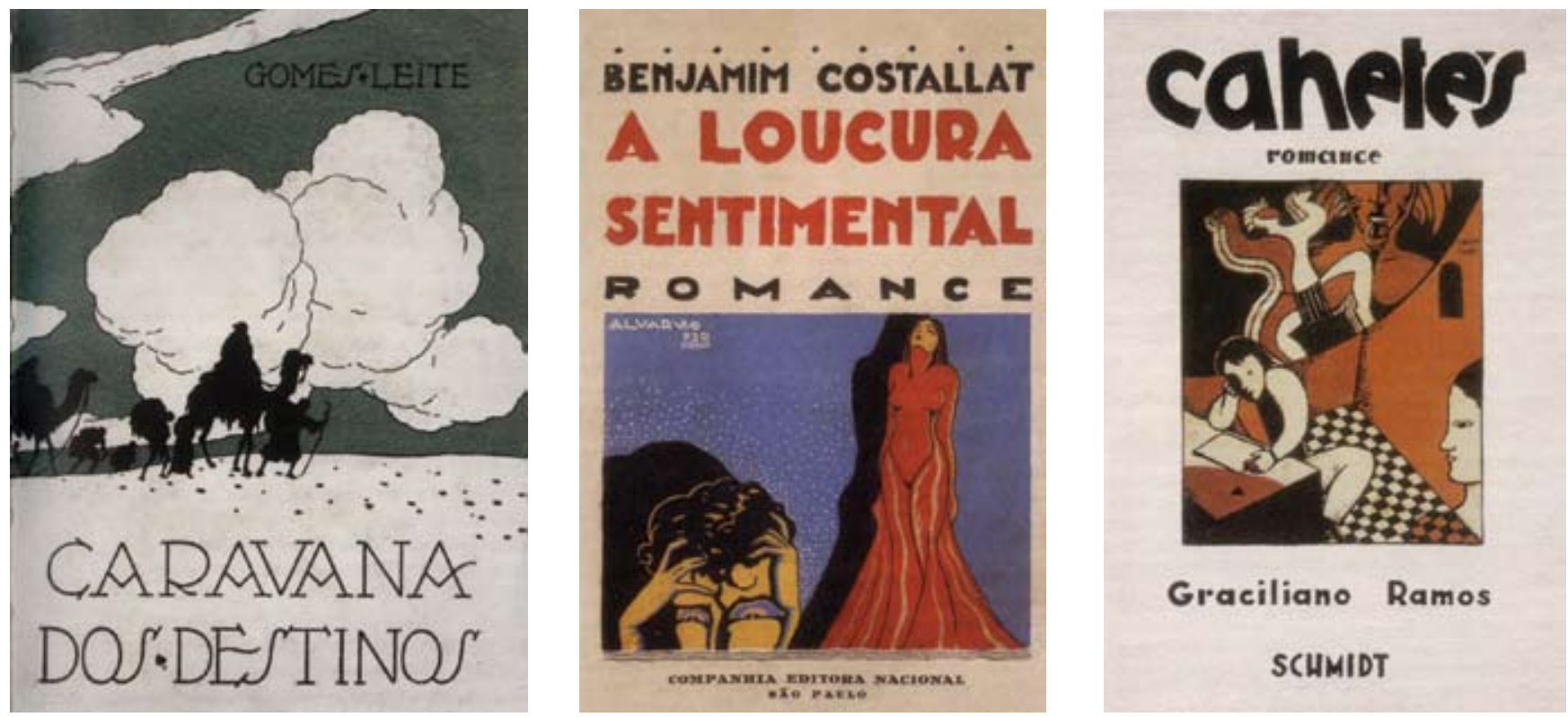

Capas assinadas por Correia Dias (1921), Alvarus (1930) e Tomás Santa Rosa (1933), exemplos do alto nível das capas brasileiras de literatura nas primeiras décadas do século XX.
No entanto, apesar de principal responsável pelo faturamento das empresas, não se vai encontrar no livro escolar o mesmo investimento em visualidade encontrado na produção de livros de literatura. Embora grande parte da produção livreira do país seguisse as convenções estabelecidas pela tradição da composição tipográfica, é nas obras de literatura que apareciam o maior cuidado com a composição, a contratação de artistas plásticos como ilustradores e capistas e mesmo projetistas dos livros. Na primeira metade do século passado, editoras como Ariel, Martins Fontes, José Olympio, entre outras, produziram brochuras de qualidade, tanto na composição de miolo, como no uso de ilustrações e desenho de capa. Com raras exceções, este investimento não vai ocorrer nos livros escolares.

Isto não quer dizer que os livros didáticos fossem mal feitos ou produzidos sem cuidado. Editoras como a Francisco Alves e a Nacional contavam com profissionais e experiência acumulada na edição de texto, composição tipográfica, revisão e ilustração, em livros bem mais difíceis de produzir que a composição "romance" ou "texto corrido" dos livros de literatura. Nisso se distinguiam de muitas outras editoras que não trabalhavam tão profissionalmente e produziam livros realmente mal desenhados e mal impressos, uma vez que para essas a venda garantida e o lucro certo não exigiam maiores investimentos em algo não valorizado e supostamente não percebido, a qualidade visual e gráfica.

Para essa baixa qualidade gráfica contribuiu também a dimensão reduzida do parque gráfico e seu relativo atraso. A tecnologia empregada na produção de didáticos - equipamentos, processos e matérias-primas - acompanhava a tecnologia do livro em geral e sua relação com as condições econômicas do país. Como exemplo dessa dependência, HALLEWELL (cit, p. 353-4) menciona o alto custo do papel para livros nas décadas de 1910 a 1930 determinando uma baixa geral na qualidade de impressão do livro brasileiro.

Já a Editora Nacional vai apresentar uma qualidade gráfica superior a de outras editoras, por circunstâncias bem particulares. Monteiro Lobato havia adqui- 

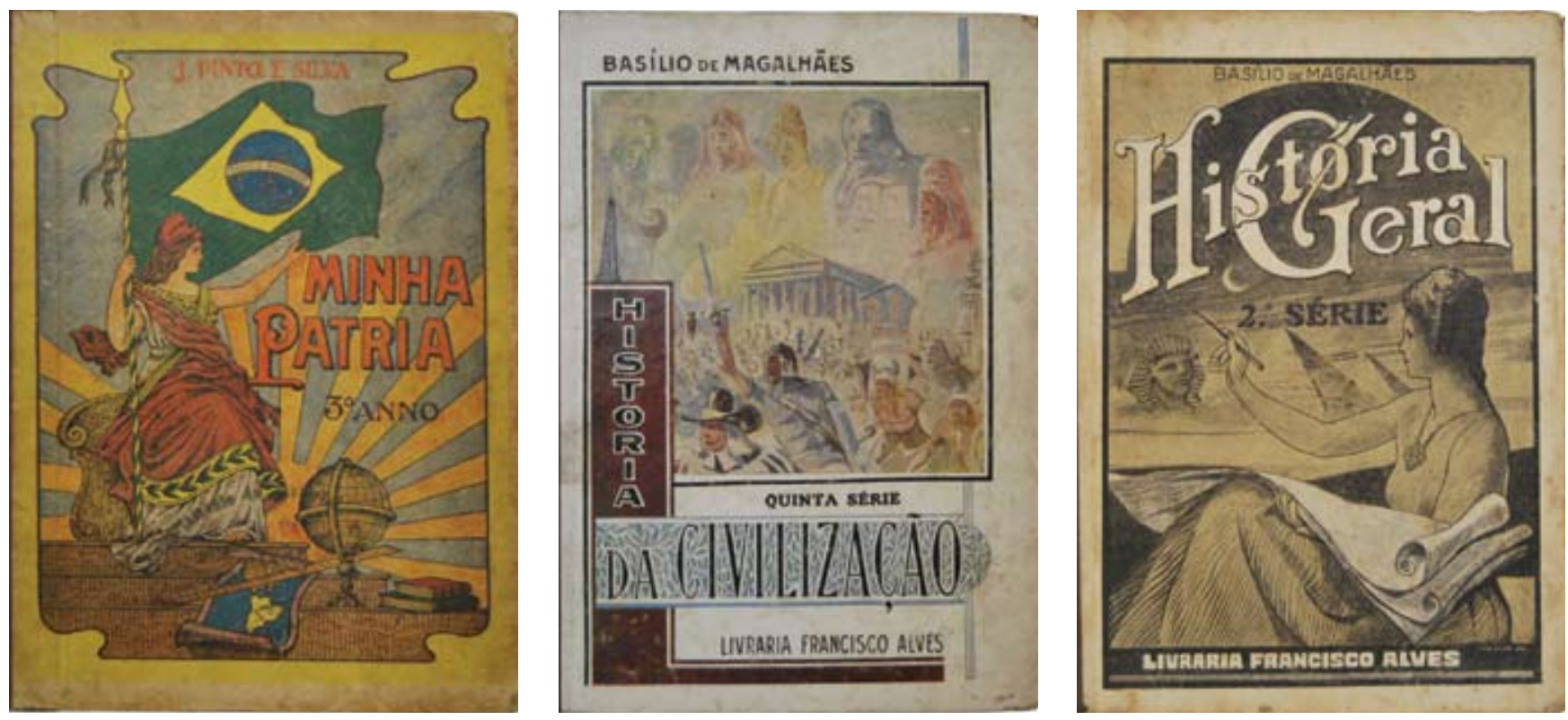

rido os equipamentos mais modernos da época, porém sua empresa faliu e ele teve de vendê-los para a Editora Revista dos Tribunais, o que fez com a condição de o comprador prestar serviços para sua nova editora, a Nacional, formada em sociedade com Octalles Marcondes Ferreira. Essa prestação de serviço, que ficou praticamente exclusiva, contou também com o trabalho do produtor gráfico Natal Daiuto, "consumado artista em produção e planejamento gráficos, cujo trabalho estabeleceu um padrão para todo o desenvolvimento posterior da aparência física do livro brasileiro, influência tão significativa no século XX quanto a de Plancher no século XIX" (HALLEWELL, cit., p. 349-350).

No entanto, como foi dito, a produção do livro didático não envolvia o mesmo investimento em linguagem visual que a produção de literatura, mesmo naquela de caráter mais popular, mas principalmente a dos autores modernistas. Independentemente da mencionada qualidade que poderia ter um didático, sua dupla condição de livro com pouco status intelectual mas de venda garantida parece pesar. Para ele se reserva primordialmente a sobriedade da transmissão de conteúdos curriculares e a consideração de que seu público não pediria mais do que isso. Para as vendas, se contava com a autoridade intelectual do autor e a seriedade de seu texto, dispensando investimento em capas como atrativo.

Assim, para o livro didático não eram chamados capistas ou artistas gráficos conhecidos, como ocorria com as obras de ficção, e ele guardaria distância da melhor produção visual, reservada para a literatura, particularmente em suas capas. No entanto, alguns trabalhos, mesmo anônimos, revelam algum cuidado e investimento das editoras, como a aplicação de ilustração impressa em cores sobre o revestimento das encadernações. A capa dura, ou cartonada, era o padrão de acabamento tradicional estabelecido para o livro, mas só excepcionalmente recebia ilustrações. Estas não eram trabalhos que acompanhavam a linguagem mais criativa dos artistas modernistas, mas talvez produzissem grande efeito dentro do gosto da época e correspondiam ao mais alto nível técnico disponível na indústria 
gráfica do período. Os temas e a iconologia eram muitas vezes "oficiais", mas também eram oficiais a ideologia e os valores cultivados na escola e nos setores bem estabelecidos da cultura brasileira.

Assim, se há uma dissociação dessa visualidade com a produzida pelos setores da cultura modernista brasileira, ela não ocorre em relação à cultura dominante e parte dos veículos de comunicação de maior penetração existentes. E, ainda que se possa reconhecer alguma defasagem, considerava-se a escola como um espaço que deveria mesmo ficar à margem das modas e valores efêmeros que se aceitavam na sociedade. Se a cultura visual, ou melhor, a sensibilidade para o fenômeno visual era algo estranho em uma sociedade que, mesmo minoritariamente alfabetizada, privilegiava o conhecimento verbal - ou até verborrágico como os modernistas denunciavam na nossa literatura e política — - não havia como a escola e os produtos destinados a ela serem diferentes.

Daí a quase impossibilidade de se atribuir importância e validade para a educação ao apelo ao visual e às imagens - a que se associava um caráter lúdico, e portanto gratuito e dispensável — no livro didático.

\subsection{Visualidade e sociedade}

Mas a importância dada ao verbal e escrito em relação ao visual não seria uma característica da escola ou mesmo da sociedade exclusivamente brasileiras, mas sim uma marca das culturas ocidentais. John Ruskin assim se referia ao divórcio entre verbal e visual:

Para centenas de pessoas que conseguem falar, uma consegue pensar. Mas para milhares que conseguem pensar, uma consegue ver. (Apud ALBERS, 2009, p. XI-XII)

Para Kress e Leeuwen, num processo iniciado há pelo menos 3500 anos, a forma como a escrita verbal se sobrepôs a outros modos de expressão conduziu a uma redução da capacidade de compreensão do modo de representação visual. Referindo-se ao processo de crescente abstração iniciado com a representação icônica hieroglífica egípcia ou suméria, passando pelo alfabeto fenício e seu desenvolvimento a oeste no mundo grego, em seu ponto de origem na versão arábica, e a leste no subcontinente indiano, os autores afirmam:

Esta é sem dúvida uma impressionante história cultural, impressionante o suficiente para se firmar como o relato histórico aceito sobre a conquista da escrita (alfabética) não questionado por séculos. Segundo este relato, todas as culturas com formas de representação visual que não eram conectadas diretamente com a linguagem verbal são tratadas como culturas sem escrita. No entanto, é preciso investigar esta história mais de perto, em particular o passo crucial da representação visual para sua ligação com a linguagem. Anterior a este passo crucial (na realidade um desenvolvimento que atravessou milênios) havia dois modos separados e independentes de representação. Um era a linguagem enquanto fala; o outro, a imagem visual, ou marcas visuais. Cada um servia a um conjunto particular de finalidades como a construção de histórias e mitos, o registro de genealogias e transações e o registro e medida de objetos. No caso de algumas culturas, no entanto, uma das formas de representação "assumiu o controle" como meio de registro; isto é, a representação visual tornou-se especializada — alguém poderia dizer, reduzida — à função como meio de representação visual da fala, talvez em sociedades altamente 
organizadas e burocratizadas. Neste ponto, o visual foi subordinado, conquistado, pelo verbal como modo de registro. Consequentemente, seus primeiros usos públicos, possibilidades e potencial para a representação independente apagaram-se, diminuíram e definharam. (KRESS; LEEUWEN, cit., p. 21-22. Trad. minha) ${ }^{\mathbf{1 5}}$

No caso de outras culturas, este desenvolvimento não teria ocorrido, com os dois meios de representação continuando a conviver. Como exemplos os autores mencionam o quipu inca, um código de nós em cordas - ou seja, um modo também tátil de representação — - e os desenhos, entalhes e pinturas em areia dos aborígenes australianos, que veiculam significados não dependentes nem traduzíveis para a linguagem verbal, enquanto esta se ocupa das narrativas. Os dois modos são conectados mas não se sobrepõem.

\section{Prosseguem os autores:}

Já nossa história não convencional da escrita considera o comparecimento conjunto da representação verbal e visual como apenas uma possibilidade e, ainda mais além, reconhece não apenas os benefícios da escrita que são suficientemente compreendidos, mas também os aspectos negativos incursos na perda de uma forma independente de representação, a diminuição de modos de expressão e representação. De nosso ponto de vista, culturas como as aborígenes australianas são vistas como tendo ambos os modos de expressão e representação: o visual (ou talvez um conjunto de formas visuais de representação) e o verbal. A questão dessa história não é apenas a questão política de solapar a noção de "cultura iletrada" (ou "cultura meramente oral") mas também a tentativa de reconhecer quanto a história convencional nos cega para os fatos e usos da comunicação visual nas assim chamadas culturas letradas. [...] O problema com que nos deparamos é que as culturas letradas sistematicamente suprimiram os meios de análise das formas visuais de representação [...] (KRESS; LEEUWEN, cit., p. 22-23. Trad. minha.)

\section{Richard Mayer aborda a mesma questão:}

Há centenas de anos, o principal formato para apresentar mensagens instrucionais tem sido as palavras, incluindo palestras e livros. Em resumo, os modos verbais de apresentação são a maneira dominante com que veiculamos explicações para os outros e a aprendizagem verbal tem sido o principal foco da pesquisa educacional. (MAYER, 2008, p. 6. Trad. minha.)

Complementando com uma descrição das diferenças entre os modos verbal e visual, Mayer prossegue:

A teoria cognitiva do aprendizado multimídia [...] baseia-se na ideia de que o ser humano possui dois canais qualitativamente diferentes para processamento de informações - um para representações construídas visualmente e outro para representações construídas verbalmente. Uma premissa dessa visão é a de que representações mentais pictoriais e representações mentais verbais são diferentes do ponto de vista qualitativo; por sua natureza intrínseca, as representações visuais e verbais não podem ser equivalentes quanto ao tipo de informação que veiculam.

Esta premissa pode ser resumida pela afirmação de que palavras e imagens são dois sistemas qualitativamente diferentes para representar conhecimento. Por um lado, a linguagem (verbal) é uma das ferramentas cognitivas mais importantes inventadas pelo homem. Através das palavras, podemos descrever algo em uma forma interpretada ou abstraída que requer um esforço mental para ser traduzida. Por outro lado, as imagens são um modo de representação de conhecimento próprio dos seres humanos. Através de imagens, podemos descrever algo de uma forma mais intuitiva e próxima de nossa experiência sensorial visual. Embora o mesmo material possa ser descrito em palavras
15 Investigando a etimologia de palavras como sintaxe e gramática, os autores localizam no período pré-helenístico ainda uma ambiguidade ou duplicidade de sentidos relacionados aos dois modos de representação. Os desenvolvimentos posteriores no período helenístico já marcam a subordinação do meio visual ao verbal, na direção dos sentidos atuais (p. 22). No entanto, a atual transposição que se faz desses termos para a análise do modo visual passa a ser imprópria e inadequada, pois já foi "contaminada" e traz a marca do raciocínio linguístico para o terreno da visualidade. 
e representado em imagens, as representações verbais e pictoriais resultantes não são equivalentes do ponto de vista informativo. E embora as representações verbais e pictoriais possam complementar uma à outra, elas não podem ser substituídas uma pela outra. (MAYER, cit., p. 91-92. Trad. minha.)

Como veremos adiante, o desconhecimento ou desprezo pelo fenômeno visual como modo de conhecimento autônomo e veículo de sentidos não só marcará a visualidade do livro didático até a década de 1960, como também será uma pesada carga no momento seguinte, em que a sociedade brasileira aceleraria sua modernização, e a circulação de mensagens através do modo visual se imporia pela presença crescente dos meios de comunicação de massa.

\subsection{Escola e visualidade}

Uma vez que levantamos a hipótese de que indústria do livro e escola se complementavam na incompreensão do fenômeno visual, o que explicaria a defasagem da visualidade do livro e sua exploração com finalidades mesmo didáticas, vamos examinar algumas possíveis causas já apontadas por importantes autores.

O desconhecimento dos elementos visuais como matéria compositiva e construtora de sentidos levava, e ainda leva, ao não reconhecimento da autonomia e da validade de outra linguagem que não a verbal como produtora de significado e conhecimento, como afirma Ana Abramowski:

No deberíamos perder de vista que la escuela, hija de la imprenta y aliada del texto escrito, tendió a asumir una actitud de sospecha ante la cultura visual de masas, a la que consideró una competidora desleal, una mera distracción o entretenimiento. Tenemos que tener presente que Occidente ha privilegiado de forma sistemática a la cultura letrada, considerándola la más alta forma de práctica intelectual, y calificando como de segundo orden, empobrecidas, a las representaciones visuales. Por ejemplo, en los libros de texto, es usual ver a las imágenes cumpliendo una función ilustrativa, subordinada a las palabras. (ABRAMOWSKI, 2009, p. 3)

A linguagem verbal é colocada como referência exclusiva para a produção de conteúdos, que deverão ser traduzidos para outros meios de expressão. O discurso imagético, mais holístico e voltado para a comunicação afetivo-relacional, é equivocadamente interpretado e subordinado à lógica linear e causal das mensagens verbais:

[...] las imágenes no son como "textos" que se "leen". Dice Mirzoeff que si nos centramos únicamente en el significado lingüístico de las imágenes visuales estamos negando un elemento que hace que éstas sean distintas a los textos. Este elemento es la inmediatez sensual. Por ejemplo, dice este autor, ver la caída del Muro de Berlín televisada en directo provocó sentimientos que excedían absolutamente a las palabras. Hay algo que resulta un "exceso" al momento de ver; sensaciones como la intensidad, la sorpresa, la conmoción, el enmudecimiento, están en el corazón de la experiencia visual y esto no puede ser agotado recurriendo al modelo textual de análisis. (ABRAMOWSKI, cit, p. 2)

Donis A. Dondis, chama visual literacy (traduzido em português por alfabetismo visual) à capacidade adquirida de ler e interpretar mensagens visuais segundo critérios próprios da linguagem visual, capacidade essa que estaria ao alcance de todos, não só criadores, mas também receptores de mensagens visuais: 
"A visão é natural, criar e compreender mensagens visuais é natural até certo ponto, mas a eficácia em ambos os níveis só pode ser alcançada através do estudo" (DONDIS, 1997, p. 16).

E atribui justamente à escola o principal obstáculo à aquisição do alfabetismo visual:

"Na verdade essa é uma esfera em que o sistema educacional se move com lentidão monolítica, persistindo ainda uma ênfase no modo verbal, que exclui o restante da sensibilidade humana, e pouco ou nada se preocupando com o caráter esmagadoramente visual da aprendizagem da criança" (DONDIS, cit, p. 17).

E, mais adiante:

"Uma das tragédias do avassalador potencial do alfabetismo visual em todos os níveis da educação é a função irracional, de depositário da recreação, que as artes visuais desempenham nos currículos escolares [...] Por que herdamos, nas artes visuais, uma devoção tácita ao não-intelectualismo? O exame dos sistemas de educação revela que o desenvolvimento de métodos construtivos de aprendizagem visual são ignorados, a não ser no caso de alunos especialmente interessados e talentosos." (DONDIS, cit, p. 17)

Publicado em 1973, nos Estados Unidos, e voltado para o desenvolvimento da compreensão do fenômeno visual e sua "sintaxe" com vistas ao treinamento de leitura e produção de mensagens no campo da comunicação visual, o texto de Dondis parece acertar no diagnóstico tanto da educação como dos meios profissionais relacionados à produção de texto e imagem na forma de livro no período que analisamos, o que talvez se estenda até hoje.

A autora, na citação mais acima, atribui o "analfabetismo visual" à visão social que se tem da importância da linguagem verbal e ao modo como se dá a aquisição do código escrito, em detrimento da arte, da sensibilidade estética e ao próprio modo não intelectual de encarar a visualidade como possuindo um corpus de conhecimento estruturado e passível de transmissão, e não ao processo de alfabetização em si.

Por relacionarem a não construção da capacidade de leitura do modo visual à interrupção da prática de expressão pelo desenho, vários autores se preocupam em localizar o momento particular da vida do indivíduo em que se deu a perda da capacidade de desenhar. A partir de indícios de que o desenhar é natural na infância - a própria prática desenhista constante e desinibida mesmo no ambiente escolar os confirmariam - , esses autores se indagam e procuram responder por que ela é bruscamente interrompida e abandonada no final da infância, marcando o fim não só de uma prática mas também do interesse definitivo pelas artes visuais. E, no nosso caso, tendo como consequência as mencionadas limitações de julgamento e de afinidade com os elementos e a sintaxe da linguagem visual justamente em atividades profissionais que os exigiriam: a configuração visual dos livros e a percepção dos valores visuais na escola.

Dessa forma, também Silvio Dvorecki localiza no momento em que se dá a alfabetização o abandono da atividade figurativa, embora não seja seu objetivo explicar como isso ocorre: 
"A criança abandona o desenho. Esta perda, circunstancial ou duradoura, da capacidade expressiva plástica é aceita pela maioria como fatalidade biológica. [...] Escola, família e meios de comunicação, solidários, como numa estratégia sem estrategistas, favorecem o abandono das atividades plásticas, fato concomitante à alfabetização. O mesmo ocorre com as outras linguagens artísticas." (DVORECKI, 1999, p. 16).

Betty Edwards (1984) também precisa o momento da alfabetização como aquele em que a intuição e a percepção holística, sintética, tarefa executada pelo lado direito do cérebro, é substituída pelas funções lógico-analíticas da linguagem verbal escrita, próprias do lado esquerdo, conforme as descobertas da neurofisiologia. Independentemente do questionamento que se possa fazer sobre a importância do aspecto "geográfico" do bloqueio — talvez apenas o correlato biológico de um processo que ocorre no aprendizado e na vivência — , a autora identifica o predomínio de uma tendência ao uso da razão e uma vontade de realismo nessa idade como contrapartida à aquisição plena da linguagem escrita. O fechamento ao modo intuitivo e sintético — o "modo do artista", como denomina — acabaria por dificultar a própria aquisição dos meios para se chegar ao realismo figurativo autoexigido, conduzindo à insatisfação com o próprio desenho e à desistência dessa linguagem. ${ }^{16}$

Como consequência, mas também alimentando esse processo de alijamento da experiência visual na escola, o livro didático era - e pode-se afirmar que em parte ainda é - visto e produzido como portador exclusivo de conteúdos disciplinares, e não como um objeto que veicula outras informações, valores e experiências. O resultado pode ser dificultar sua tarefa não só de atingir objetivos didáticos específicos, como também de cumprir um papel pedagógico mais amplo, de formador de gosto e propiciador de experiência com as linguagens e suas relações para a construção de significados.

\subsection{Design e livro didático}

Como vimos, vários modos concorrem para a construção dos sentidos em um livro didático. O modo visual, corporificado na prática do design gráfico, tem especial destaque pelo que comunica de forma mais imediata a seu público. No entanto, a presença do design na construção das personalidades e sua influência na vida social nem sempre é percebida. Nesse sentido, Adrian Forty é enfático:

\footnotetext{
16 Uma das consequências desse desenvolvimento estanque das capacidades verbais em detrimento de outras é que a própria capacidade verbal acaba por ser atingida como recurso expressivo, de criação e de compreensão do mundo e da vida. 0 fechamento do indíviduo a outras expressões e manifestações em arte é inequivocamente um fechamento a outras dimensões da experiência humana propiciada por todos os sentidos e linguagens artísticas.
}

\begin{abstract}
A mesma escassa atenção foi dada à influência do design em nossa forma de pensar. Aqueles que se queixam dos efeitos da televisão, do jornalismo, da propaganda e da fiç̧ão sobre nossa mente esquecem a influência similar exercida pelo design. Longe de ser uma atividade artística neutra e inofensiva, o design, por sua própria natureza, provoca efeitos muito mais duradouros do que os produtos efêmeros da mídia porque pode dar formas tangíveis e permanentes às ideias sobre quem somos e como devemos nos comportar. [...]

Ao contrário da mídia mais ou menos efêmera, o design tem a capacidade de moldar os mitos numa forma sólida, tangível e duradoura, de tal modo que parecem ser a própria realidade. (FORTY, 2007, p. 12 e 13)
\end{abstract}

Embora esta citação se refira à presença constante de objetos ou a ambientes criados pelo design industrial encarnando mitos como, por exemplo, de que o tra- 
balho em escritório é menos rotineiro e mais criativo do que nas fábricas, a partir do uso de mobiliários com cores vivas e formas alegres, o que dizer da presença das formas e cores (ou falta delas) nos livros didáticos por um período tão extenso e num momento tão decisivo para a formação dos indivíduos como é o da vida escolar?

Os livros, no que diz respeito a seu design específico, seriam, em tese, objetos unitários, portadores de um conteúdo escrito disposto em folhas e protegido por uma capa. Além dos aspectos materiais e de produção, o design teria que se ocupar da configuração do conteúdo — como está distribuido nas páginas, como texto e imagens se relacionam —, com vistas à eficácia em sua transmissão ou, pelo menos, a não criar obstáculos para ela. Mas, além dos aspectos puramente funcionais, o design do livro pode se ocupar de objetivos motivacionais, criando formas para interessar e prender a atenção do leitor a partir da emoção e a referências ao universo do leitor.

Isso se expressaria não só no interior do livro, mas em sua capa, e na relação desta com o interior, como porta de entrada que é para ele. No livro como mercadoria, esses objetivos motivacionais se expressam na capa antes da experiência com a leitura, por meio do design. Mas para realizar o trabalho de induzir à venda, o design precisa representar e construir sentidos que envolvem os significados expressos no conteúdo textual e na sua relação com a cultura escrita e visual bem como com o mundo interior do leitor. Com isso, capas são também objetos da cultura.

Assim, o objeto livro pode ensinar e dizer coisas além do que o estrito conteúdo escrito de suas páginas. Ele é uma expressão concreta de relações sociais e ideias circulantes, um produto da cultura material. Veicula informação textual mas também visual e, em inteiração com outros veículos visuais e com o ensino, participa da formação do gosto de seu leitor, principalmente pela continuidade de sua presença nos anos de formação intelectual dos indivíduos.

Por isso, além dos objetivos pragmáticos relativos à organização dos conteúdos com vistas à sua transmissão mais eficaz, o design gráfico de um livro pode também educar ou deseducar visual e culturalmente no sentido mais amplo. Pode portar uma visualidade que apenas repete a visualidade cristalizada própria de um gênero produzido sem grande investimento criativo, como se identificou na produção majoritária do livro escolar brasileiro. Pode também apenas se apropriar e reproduzir os clichês veiculados por outras mídias, como se observou em capas da década de 1970 que serão aqui reproduzidas. Ou pode ampliar a informação imagética e o repertório visual de seu público e apresentar a linguagem visual e o próprio design como modos de conhecimento e manifestações válidas da cultura, papel que, acreditamos, tiveram as capas apresentadas na Parte Il do trabalho. 


\subsection{Os papéis da capa}

Quando do surgimento do códice manuscrito, a capa tinha unicamente a função de proteger as folhas, e não de identificar seu conteúdo ou promover sua venda, como no livro moderno. Assim, as capas eram de couro, gravado ou não, às vezes em dourado, ou então obras de ourivesaria, refletindo seu valor como objeto único e o poder econômico de seu proprietário — mas, mesmo quando decoradas não recebiam inscrição ou ilustração figurativa relacionada ao conteúdo.

Isto não ocorreu nem quando o livro passou a ser produzido em massa, a partir da invenção da tipografia. A identificação da obra, autoria, edição e oferecimento apareciam na página de rosto e às vezes em uma proteção em papel mais encorpado que reproduzia a página de rosto, mas que seria removida para a encadernação feita depois da compra.

Com a industrialização da encadernação, a identificação da obra passou a vir numa sobrecapa, que funcionava também como propaganda e indução para a compra, mas que não pertencia ao corpo do livro e que podia ser removida. Com a generalização da brochura, as capas em papel encorpado coladas ao corpo do livro assumiram a função publicitária que era feita pela sobrecapa. A encadernação cartonada também permitiu a impressão de capas duras com essa característica de promoção das vendas. ${ }^{17}$

A capa, como propaganda e convite a se conhecer o livro, em tese deveria se relacionar estreitamente com seu conteúdo, em dois aspectos: como referência ao assunto e às ideias, isto é, ao conteúdo impresso, e à forma como esse conteúdo é apresentado, isto é, ao partido e à linguagem de design do miolo.

Mas esta é uma visão que parte da ideia do livro como objeto unitário de design, uma visão própria da cultura do design estabelecida a partir da Bauhaus e do modernismo, em muitos sentidos uma conquista cultural que aparece na melhor produção livreira hoje. A cultura do design levou algumas décadas para se estabelecer e nem sempre coincidiu ou coincide com a cultura comercial e do consumo de massas.

Como já foi visto, há exemplos de editoras brasileiras nas primeiras décadas do século XX explorando o potencial comunicativo e indutor das capas como incentivo à decisão de compra por parte do público. O mesmo parece não ter ocorrido com as editoras didáticas no mesmo período e mesmo depois, provavelmente por não se atribuir a aspectos visuais grande peso na tomada de decisão por adotar um livro escolar.

Será apenas com a expansão da indústria cultural a partir da década de 1970 que a preocupação com esse item começará a se generalizar, mas o já mencionado desencontro entre escola e indústria do livro didático por um lado, e cultura visual e design por outro, imporá uma maioria de soluções pobres e pouco significati-

17 Para uma descrição física da capa como elemento extratextual e seu desenvolvimento em relação à história do livro, ver ARAÚJ0, 2006, pp. 470 a 472 e 601. vas para este produto, mantendo-o distante da visualidade encontrada em outros meios de comunicação impressa, incluindo o livro não escolar.

A função da capa como proteção do conteúdo não deixa de existir pela predominância da função publicitária, e também pode ser englobada por esta. Com 
a capa como continente de um conteúdo (físico, as folhas; simbólico, as ideias) já ocorre comunicação e significados são veiculados: as qualidades físicas de seu material — dureza, flexibilidade, textura, espessura, união física com as folhas internas - podem fazer parte de um discurso de convencimento relacionado a expectativas de durabilidade, de praticidade no uso, de luxo, de produto "muito especial" etc. Assim, as qualidades físicas dos materiais empregados na produção de capas aparecem como signos de outras qualidades desejadas, em um discurso também voltado para a persuasão.

Também a função de identificação, seja de autoria, de título ou de editor, transcende por si o etiquetamento para reconhecimento na estante. Por exemplo, a simples inscrição do título ou do autor pode portar prestígio e transmiti-lo ao possuidor do livro em questão, tanto para deleite próprio como para comunicar aos outros.

O título, associado ao nome do autor, ou, muitas vezes, apenas a grafia do nome do autor numa capa, é manifestação suficiente do ethos que garante a validade da obra e conduz à sua aquisição pelos segmentos que se identificam com ela. Há inúmeras coleções em que o elemento gráfico principal é o nome do autor, associado ou não a sua imagem pictorial, ficando o título em segundo plano. Em títulos didáticos o fenômeno ocorre com frequência. O prestígio do autor, conquistado em obras de um segmento de ensino ou de determinado tema, é explorado em outros.

A empresa que organiza os meios necessários para a veiculação da obra e efetivamente a põe ao alcance do leitor-consumidor também traz presente sua assinatura na capa, e o faz de duas formas possíveis não excludentes: pela aplicação de um selo, marca ou logotipo e por uma determinada organização visual, única, dos elementos constitutivos da capa, que a tornam um fator de identificação e reconhecimento pelo público.

Assim, as funções de proteção e identificação combinam-se na estratégia de veicular um discurso de convencimento voltado para o potencial comprador. Mas esse discurso hoje precisa ser essencialmente visual e incorporar os diversos componentes textuais na construção de uma imagem, que pode incluir elementos pictoriais também. Esse conjunto, essa imagem, de alguma forma deve ser uma representação, um signo do conteúdo da obra.

Mas o conteúdo de uma obra, que em si articula uma miríade de signos, verbais e às vezes também visuais, apresenta uma quantidade de significações e uma complexidade certamente impossível de ser sintetizada e traduzida por um único signo. Como vimos, cada modo - verbal e visual - tem seu potencial próprio para veicular determinados sentidos e não outros, e há um hiato entre eles quanto à possibilidade de traduzir significados de um plano de expressão a outro sem perdas significativas. Assim, a tarefa de impor à capa a obrigação de transmitir um sentido "primordial" que sintetizaria o alcance da obra como estratégia de convencimento está em princípio destinada ao fracasso.

Como todos os sentidos veiculados por uma obra só são acessíveis a quem efetivamente lê-la, a capa pode se reservar um papel mais modesto e ao mesmo 
tempo mais difícil, o de ser um índice mais ou menos imaginativo e livre do que o leitor vai encontrar no interior do livro. Por não ser uma obra autônoma e depender de uma relação com o conteúdo, a capa pode ter alguma relação de contiguidade ou de conexão com o conteúdo no sentido de oferecer elementos que convidem o leitor a descobrir os sentidos que só a leitura da obra propiciará. No aspecto de contiguidade física com o conteúdo composto graficamente, isto é, em termos de projeto gráfico do livro como objeto unitário, essa poderia ser uma maneira de ver as relações entre capa e miolo.

O discurso de convencimento da capa pode se dar uma vez que ela assuma explicitamente o papel de peça publicitária, na forma de embalagem-cartaz da obra que se apoia no prestígio do filme a que deu origem (ou do qual se originou), no prestígio do autor ou até no da editora, e em reações conhecidas do público, através da veiculação de estereótipos que asseguram a compreensão da mensagem, com a finalidade única e exclusiva de induzir à compra. Em termos de senso comum, como toda propaganda, pode ser enganosa ou verdadeira: quem comprar e ler é que poderá julgar.

Esse mesmo discurso pode se dar de forma mais sutil e rica, a partir de relações com aspectos do plano mais profundo do conteúdo, em diálogo com suas ideias e oferecendo ao leitor possibilidades de leitura da obra além das mais imediatamente percebidas. A capa, como manifestação visual que articula palavra e imagem em outro plano de expressão diferente do verbal escrito, mas em estreita relação com a obra a que se liga e com seu significado estético e social, e apresentando qualidades próprias como discurso visual relativamente autônomo capaz de propiciar fruição estética, ganha assim seu caráter de objeto cultural único e especial.

Mesmo em obras didáticas, com conteúdo a priori conhecido e que não oferece grandes surpresas, essas qualidades podem aparecer, como será encontrado na Parte II deste trabalho. 


\section{CAPAS DE LIVROS DIDÁTICOS NOS ANOS 1970: UM PANORAMA}

\subsection{0 crescimento da indústria editorial didática na década de $\mathbf{1 9 7 0}$}

A década de 1970 assistiu a uma expansão sem precedentes de editoras e títulos, rela-cionada primordialmente à expansão da rede escolar pública e privada - no primeiro caso, decorrente das lutas e pressão popular para que o Estado assumisse sua responsabilidade de oferecer o ensino primário gratuito e obrigatório estabelecido na Constituição de 1946. Também foram determinantes para o crescimento desse mercado a estruturação de todos os níveis do ensino estabelecida pela Lei de Diretrizes e Bases da Educação Nacional, promulgada em 1961 e, mais tarde, a reforma do ensino de $1 .^{\circ}$ e $2 .^{\circ}$ graus, de 1971 . Embora não tenha vingado a tentativa de criar o ensino profissionalizante de nível médio prevista por esta reforma, a unificação dos antigos cursos primário e ginásio num único curso de 1. grau com duração de oito anos e sua obrigatoriedade, bem como o aumento do número de disciplinas obrigatórias dos dois graus em todo o território nacional, foram fatores determinantes para a ampliação do mercado de livros escolares. ${ }^{\mathbf{1 8}}$

Os anos 1970 iniciam-se mantendo a grande expansão do ensino público e privado em todos os níveis iniciada na década anterior. De 1960 a 1972, o número de matrículas no Ensino Primário (atual Fundamental I) salta de 7,4 milhões para 14,5 milhões, a um crescimento médio anual de 5,7\%. Para o Ensino Médio Primeiro Ciclo (atual Fundamental II), de 910 mil esse número passa para 3,9 milhões, com13,0\% de crescimento médio anual. No Ensino Médio Segundo Ciclo (atual Médio) salta de 267 mil para 1,3 milhão (taxa média anual de 14,2\%). No Ensino Superior, em nível de graduação, pula de 93 mil para 688 mil no mesmo período, o que significa uma taxa média anual de aumento de 18,1\%.19

Esses números encerram grandes contradições. Expressam a pressão popular sobre o Estado por educação básica, que já resultara na ampliação da rede pública, principalmente após 1955, e na aprovação da Lei de Diretrizes e Bases da Educação Nacional, em 1961. Expressam as necessidades de expansão da indústria e dos serviços já observadas com o desenvolvimento da indústria de base e automobilística nos anos 1950, e particularmente depois do golpe militar de 1964, que impôs um novo arranjo na participação do capital estrangeiro na economia brasileira, com a introdução e expansão de uma indústria voltada para o consumo das camadas médias e altas. Mas o Estado, sob a direção do novo regime, não dispunha de recursos para investir na infraestrutura necessária à industrialização e à atração de capitais externos e na educação ao mesmo tempo. Assim, as matrículas nos níveis básicos do ensino não dão conta do crescimento populacional e, no ensino superior, a insuficiência de vagas será responsável pela crise dos excedentes, que desembocará na reação estudantil no final da década de 1960 e na resposta do regime com o incentivo à expansão do ensino privado, particularmente o superior, ao lado das medidas repressivas destinadas a qualquer contestação a esse modelo. ${ }^{\mathbf{2 0}}$

Mas o que nos importa é que esses números dão a ideia da dimensão da

18 Sobre a LDB de 1961, ver ROMANELLI, 2002, p. 179-183. Sobre a Lei n. ${ }^{5} 5692 / 71$, idem, p. $233-254$.

19 Dados obtidos em LEAL, 1984, p. 177.

20 ROMANELLI apresenta o crescimento da oferta de ensino e as contradições da política educacional do regime militar, que divide em dois momentos, do golpe a 1968 e a partir dessa data (cit., p. 193-210). 
demanda por livros escolares em números absolutos em todos os níveis, da qual resultou uma expansão sem precedentes desse ramo da indústria livreira. A título de ilustração: Hallewell menciona a existência de 2500 títulos didáticos à venda em 1968, produzidos por 60 editoras (embora 80\% deles pertencesse a apenas 16); o Snel (Sindicato Nacional dos Editores de Livros) menciona 5986 títulos em 1969 (Hallewell, 2008, p. 556 e 558). A interpretação gráfica da tabela encontrada em HALLEWELL (cit., p. 559), referente ao total de livros didáticos produzidos de 1966 a 1980, mesmo sem dados para todos os anos, apresenta a dimensão desse crescimento.

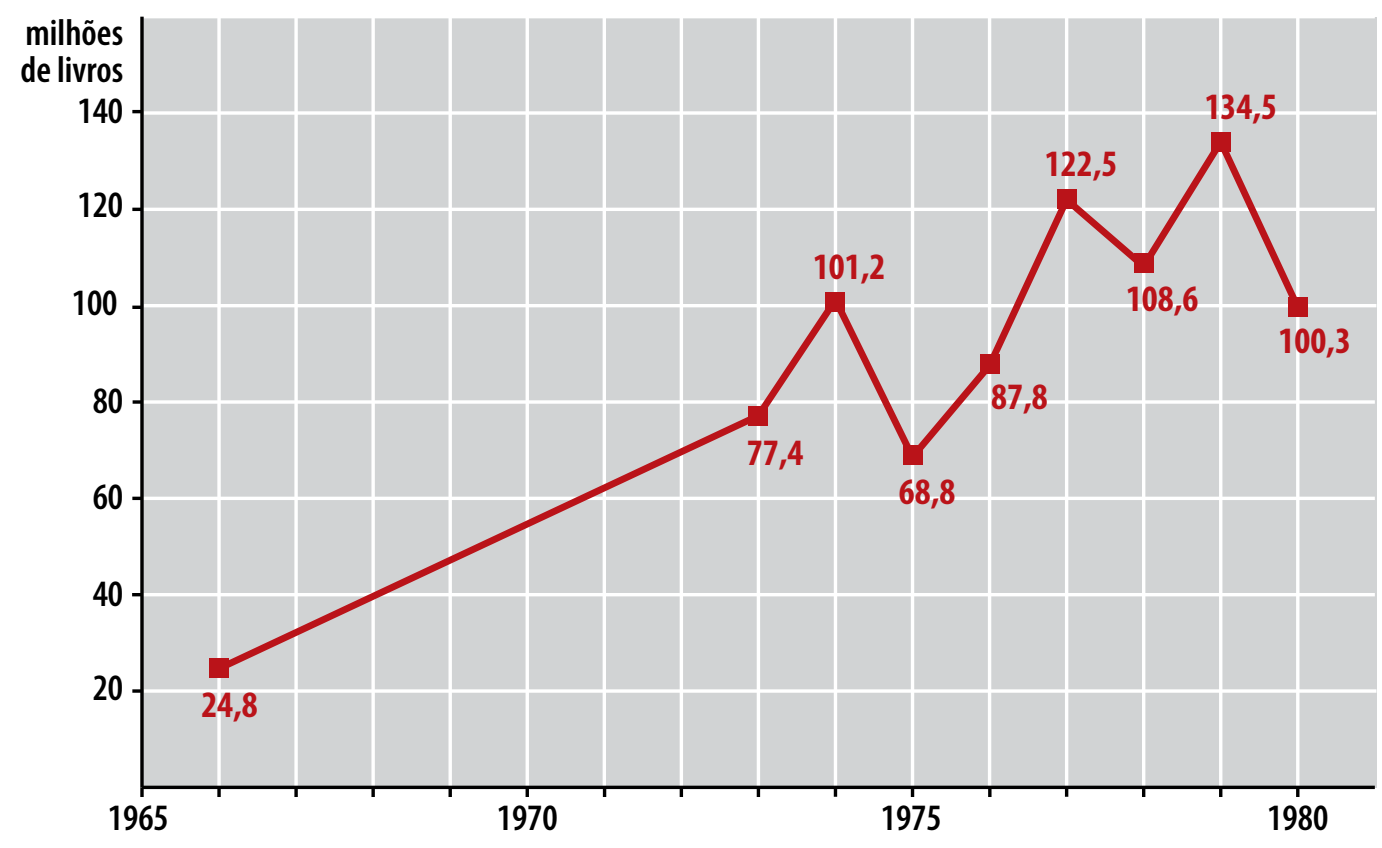

Gráfico 1: Produção anual de livros escolares de 1966 a 1980 (Fonte: Hallewell, 2008, p. 559.)

O crescimento da indústria do livro didático foi também favorecido por subsídios e pela compra governamental, a partir da formação da Comissão Nacional do Livro Técnico e Didático (COLTED), em 1966, e de financiamento da USAID (Unites States Agency for International Development) no valor de 9 milhões de dólares para a compra e distribuição de livros, que chegou a quase 16 milhões de exemplares em 1969 (HALLEWELL, cit., p. 558-560).

Esses números são a contrapartida lógica da expansão da rede pública e privada do ensino Brasil naqueles anos e explicam não só o crescimento de editoras de didáticos já existentes no país, mas principalmente o surgimento de novas editoras voltadas exclusivamente para a produção e distribuição de livros escolares no final dos anos 1960 e início dos anos 1970.

Assim, entre as 16 editoras que concentravam 80\% da produção em 1968, estão as tradicionais Francisco Alves (1897), Melhoramentos (1915), Companhia Editora Nacional (1925), Agir (1944) e Editora do Brasil (1943). Poucos anos depois, os nomes também tradicionais da Saraiva (1917, didáticos desde 1930) e FTD (1902), mais os das recém-fundadas Ática (1965), IBEP (1965) e Moderna (1968), despontarão como campeões de venda, suplantando as primeiras mencionadas. Se em 1979 
os didáticos já correspondiam a 36,2\% do mercado editorial, na segunda metade dos anos 1980, com novas editoras fundadas na década de 1970, como a Atual e a Scipione, serão o principal segmento da produção livreira nacional (PAIXÃO, 1995, p. 161, e HALLEWELL, cit., p. 562-565).

Qual será o aspecto visual desse volume inédito de títulos despejado na escola e no mercado? O que significará o peso econômico da produção didática para a configuração material e visual do livro produzido nesses e nos anos subsequentes? O que a presença da tantas novas editoras significará para a visualidade do livro escolar no país?

\subsection{A cultura de massas e os novos meios audiovisuais}

É também na década de 1970 que, paralelamente ao crescimento do mercado de didáticos, ocorre uma expansão da indústria cultural de massas e a afirmação de uma cultura jovem autônoma. Os dois fenômenos estão profundamente ligados e os anos 1970 aprofundam o que se desenvolveu na década anterior, mas que teve início no pós-segunda guerra mundial. Embora se atribua ao regime militar a dependência da economia brasileira ao capital externo e seu correlato na indústria cultural, com a responsabilidade pela importação de modelos culturais estrangeiros, particularmente norteamericanos, este é um movimento bastante contraditório e de caráter internacional, independente da vontade de governos mais ou menos "entreguistas".

A terceira peculiaridade da nova cultura jovem nas sociedades urbanas foi seu espantoso
internacionalismo. O blue jeans e o rock se tornaram marcas da juventude "moderna", das
minorias destinadas a tornar-se maiorias, em todo país onde eram oficialmente tolerados
e em alguns onde não eram, como na URSS a partir da década de 1960 [...]. Letras de
rock em inglês muitas vezes nem eram traduzidas. Isso refletia a esmagadora hegemonia
cultural dos EUA na cultura popular e nos estilos de vida [...] Seus estilos juvenis se difun-
diam diretamente ou através da amplificação de seus sinais via a intermediária cultural
Grã-Bretanha, por uma espécie de osmose informal. Difundiam-se através dos discos e
depois fitas, cujo grande veículo de promoção, então como antes e depois, era o velho
rádio. Difundiam-se através da distribuição mundial de imagens [...] Difundiam-se ainda
pela força da moda na sociedade de consumo que agora chegava às massas, amplia-
da pela pressão dos grupos de seus pares. Passou a existir uma cultura jovem global.
(HOBSBAWN, 1996, p. 320)21

A partir de 1970, a televisão se torna o veículo de maior impacto e penetração para a circulação de imagens e de modelos e estilos de comportamento. Mas as revistas dirigidas a novas camadas de público também alcançam todos os cantos do país. A publicidade, incentivando o consumo real ou imaginário, conforme o poder aquisitivo de quem a recebia, veiculava também imagens e estéticas, e estas eram consumidas por todos.

Mas a indústria cultural em si não é novidade, já existia décadas antes e os veículos impressos e o rádio portavam linguagem e estéticas correspondentes a ela e às tecnologias vigentes, produzindo e modificando permanentemente uma cultura de massas no país. O que é novo é a presença de uma indústria cultural voltada para a juventude, apresentando produtos gráficos e com determinadas

21 Sobre" 0 nascimento e a formação da cultura adolescente no seio da cultura de massas" e sua universalidade, ver também MORIN, 2009b: p. 137-155. 
características de visualidade com apelo a um público até então desconsiderado. E o que também é novo é o padrão de realismo e qualidade determinado pelas tecnologias de obtenção e reprodução da imagem fotográfica, cinematográfica e impressa.

Referindo-se à imprensa infantil como "literalmente criada pela indústria cultural" e à imprensa adulta como "impregnada de conteúdos infantis", afirma Edgar Morin ainda na década de 1960 na França:

Essa homogeneização das idades tende a se fixar numa nota dominante: a dominante juvenil. Esbocemos aqui uma observação que encontraremos mais adiante: a temática da juventude é um dos elementos fundamentais da nova cultura. Não são apenas os jovens e os adultos jovens os grandes consumidores de jornais, revistas, discos, programas de rádio (a televisão, como veremos, é exceção), mas os temas da cultura de massa (inclusive a televisão) são também temas "jovens". (MORIN, 2009a, p. 138-39)

A imagem é parte integrante da cultura trazida pelos novos meios dessa indústria:

Enfim, uma linguagem não mais sincrética, porém universal no que tem de imediatamente concreta, também se propala: a linguagem das imagens, fotografias, filmes, comics, publicidade, cartazes. (MORIN, 2009a, p. 160)

Sobre o alcance e os efeitos da cultura visual numa sociedade como a brasileira daqueles anos:

Podemos interrogar-nos sobre o seguinte: nas sociedades ocidentais, são as transformações econômicas, principalmente o progresso industrial, que transformaram as mentalidades. No Terceiro Mundo, a indústria ultraligeira, as das comunicações (rádio, cinema, antes de qualquer outro), começa a revolucionar as mentalidades antes mesmo que a sociedade seja transformada. Nos países ocidentais, o alfabetismo foi difundido antes da cultura audiovisual. No Terceiro Mundo, o processo é, com frequência, invertido. A cultura audiovisual se propaga por imensas zonas ainda analfabetas. (MORIN, 2009a, p. 161)

É nesse novo contexto de crescimento da indústria cultural, com mensagens e imagens dirigidas às crianças e aos jovens que se dá o crescimento da população escolar e dos instrumentos de ensino, principalmente o livro escolar. Crianças e adolescentes de quase todo o país viam televisão com seus programas e publicidade, consumiam gibis e outras revistas, além de objetos produzidos especialmente para suas idades, e... livros didáticos. Qual então a relação da visualidade desses livros com a dos novos e antigos veículos de imagens e informações? Eram eles produzidos com a mesma tecnologia e portavam as mesmas linguagens que atingiam seu público por todos os outros lados? A visualidade dos meios de comunicação se manifestava também nos livros escolares? Se sim, e em que grau?22

\footnotetext{
22 Dado o volume de exemplos que seria necessário reproduzir para caracterizar a visualidade da década de 1970, optamos por apenas indicar uma fonte onde ela pode ser encontrada, 0 Almanaque anos 70, de Ana Maria Bahiana (2006)
} 


\subsection{As capas da década}

A pesquisa e documentação fotográfica de capas de livros didáticos de diversas disciplinas realizada principalmente na Biblioteca do Livro Didático da Faculdade de Educação da Universidade de São Paulo²3 revelou três tendências ou agrupamentos principais no que se refere à visualidade dos livros na década de 1970.

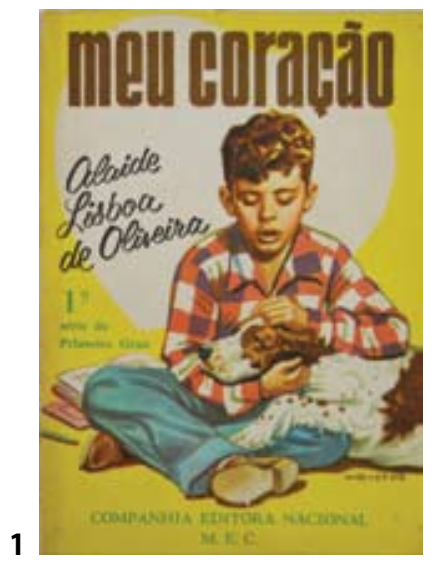

\section{1. a tendência: as capas "tradicionais"}

Nesse grupo se percebe a permanência de linguagens encontradas na década anterior, proveniente de uma abordagem "tradicional" ou convencionada para os livros escolares, por sua vez proveniente até de anos anteriores a 1960. Aqui se encontraram desde realizações novas que conservavam essa abordagem, até capas criadas em décadas anteriores que não foram renovadas e continuaram sendo publicadas. Feitas ou não com propriedade e conhecimento profissional da linguagem visual, refletem uma visualidade que não acompanha os novos meios técnicos e as imagens que circulam na sociedade brasileira daqueles anos.

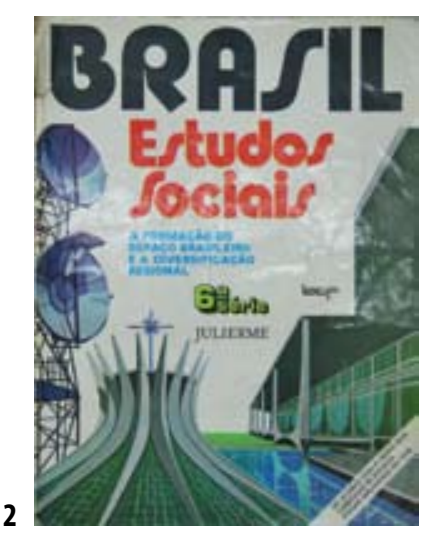

\section{2. " tendência: as capas novas "sem projeto"}

Este grupo reúne as capas que de alguma maneira procuravam se alinhar com a visualidade que se manifestava na publicidade, nas revistas, nas modas e na televisão mas que não eram executadas com o mesmo domínio da linguagem visual e das técnicas de comunicação e metodologia projetual que apareciam nesses veículos. Essas realizações constituem a imensa maioria das capas produzidas no período e indicam a influência dos meios de comunicação de massas que se generaliza nessa década bem como a utilização das novas tecnologias ou equipamentos de composição, reprodução fotográfica e impressão, mas carregam as contradições de uma indústria que não reconhece a importância ou não sabe como valorizar visualmente seus produtos e não se vincula a nenhuma proposição cultural.

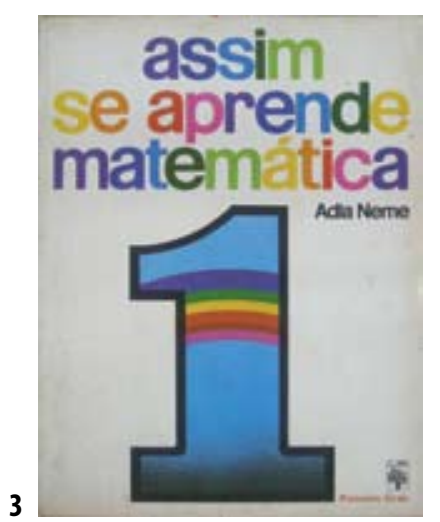

\section{3. a tendência: as capas "inovadoras"}

Este terceiro grupo é o das realizações que, refletindo a influência dos meios de comunicação de massa ou do design modernista que se implantava no país, eram executadas com maior domínio da linguagem visual, conhecimento dos novos recursos gráficos e, principalmente, uma atitude projetual. Neste grupo se reúne desde a produção interna das editoras que prossegue com o bom design editorial "tradicional" voltado para o livro escolar e sua especificidade, até as incursões do design

1 Meu coração, 1.a série. Adelaide Lisboa de Oliveira. Nacional, 1973. Capa Augustus. $(18,7 \times 13,2 \mathrm{~cm})$

2 Brasil, Estudos Sociais: a formação do espaço brasileiro. Julierme de Abreu e Castro. Ibep, 197? Capa Angelo Beja. $(27,5 \times 20,5 \mathrm{~cm})$

3 Assim se aprende matemática, v. 1. Adla Neme. Abril Cultural, 1977. Capa J. Ramos Netto e Mário Cafiero. $(27,5 \times 20,5 \mathrm{~cm})$

\footnotetext{
$\mathbf{2 3}$ Este importante acervo, em esforço permanente de construção, certamente ainda apresenta lacunas e desequilíbrio na representação de disciplinas e períodos, decorrente das dificuldades para a obtenção de exemplares elencadas no primeiro tópico da Parte 1. No entanto, reúne 0 que não se consegue encontrar nem disperso, uma vez que a maioria das editoras não possuem memórias de suas publicações ou não as abre à pesquisa. E o que essa Biblioteca apresenta é mais do que suficiente para se reconhecer a visualidade do livro escolar no país em diversas épocas.
} 
24 A pesquisa e documentação fotográfica, facilitada pela consulta online ao Livres - Banco de Dados de Livros Escolares Brasileiros - pretendia inicialmente localizar todos os livros de todas as disciplinas do acervo dentro do período estudado, os anos 1970. 0 acesso direto às estantes, no entanto, permitiu 0 confronto com obras de outros períodos e revelou a conservação de linguagens anteriores, obrigando a se estender a documentação. Assim, além das 151 capas encontradas pertencentes à década de 1970, fotografaram-se 51 da década de 1960, 18 da década de 1950 e 12 das décadas anteriores, perfazendo um total de 257 capas fotografadas. Além dessas, 0 acervo da Editora Nacional, agora temporariamente fechado, forneceu 15 capas, e 0 da Ática, também provisoriamente fechado, 155, elevando 0 total da documentação à 427 capas. modernista ensinado nas poucas escolas da época, passando pela influência do design praticado nas redações de revistas de grande tiragem e até na publicidade. Essas realizações constituem uma minoria diante da quantidade de capas que representam a segunda tendência.

Assim, a década de 1970 tem a peculiaridade de conservar o que já se fez, apresentar tentativas de renovação que carregavam as contradições do passado (e do seu presente) e por fim efetivamente apresentar novas linguagens e caminhos. Uma condição de encruzilhada, reflexo de uma sociedade em transformação, sob o impacto da industrialização e da urbanização, com grandes desigualdades regionais e vivendo a presença crescente dos meios de comunicação de massa e da indústria cultural, ao mesmo tempo que a educação se expandia em níveis sem precedentes.

Até o livro escolar, que, como vimos, se mantinha mais ou menos à margem do debate cultural e da influência das artes e do design modernista, vai expressar em diversas visualidades a coexistência das tendências mencionadas, algumas contraditórias, apresentadas mais detalhadamente a seguir. ${ }^{\mathbf{2 4}}$

\section{$4.410^{\circ}$ grupo: as capas "tradicionais" ou "vernaculares"}

Um número não desprezível de livros escolares no Brasil, até a década de 1960, continuava sendo produzido dentro das técnicas e do desenho estabelecidos pela tecnologia tipográfica: composição em linotipo, ilustrações em uma cor, impressão em tipografia. Os livros destinados às séries mais avançadas e os produzidos nos centros regionais mais distantes eram espartanos no visual e no material empregado. Mesmo os livros de grandes e tradicionais editoras, como a Francisco Alves, a Editora do Brasil, e parte da produção da Nacional, embora impressos em offset e contendo reprodução de fotografias e ilustrações coloridas, conservavam a linguagem encontrada em livros produzidos em décadas anteriores, quando não eram a reimpressão pura e simples deles.

Essa visualidade - dominante na década de 1960 e encontrada nas revistas populares e sua publicidade, nos álbuns de figurinhas de futebol, nos rótulos e embalagens de produtos alimentícios regionais ou mesmo nacionais - correspondia à estética e à tecnologia de uma indústria gráfica tradicional e chegou a muitos livros escolares e suas capas na década de 1970.

Em parte, a permanência dessa visualidade pode ser atribuída ao atraso tecnológico do parque gráfico nacional. Apesar de incentivos ocorridos durante o governo Juscelino Kubitschek e de uma modernização pontual, no início da década de 1960 a idade média dos equipamentos era ainda de 35 a 40 anos. Em 1966, empresários do setor gráfico conseguiram do governo federal a formação de um órgão consultivo, o GEIPAG — Grupo Executivo das Indústrias de Papel e Artes Gráficas - que, com base no diagnóstico do atraso tecnológico de pelo menos uma geração, obteve a isenção de taxas de importação de máquinas. Ocorre uma modernização mais ampla, com um maior número de impressoras offset substituindo a tipografia e a aplicação das capas ao miolo se automatizando, mas essa moder- 

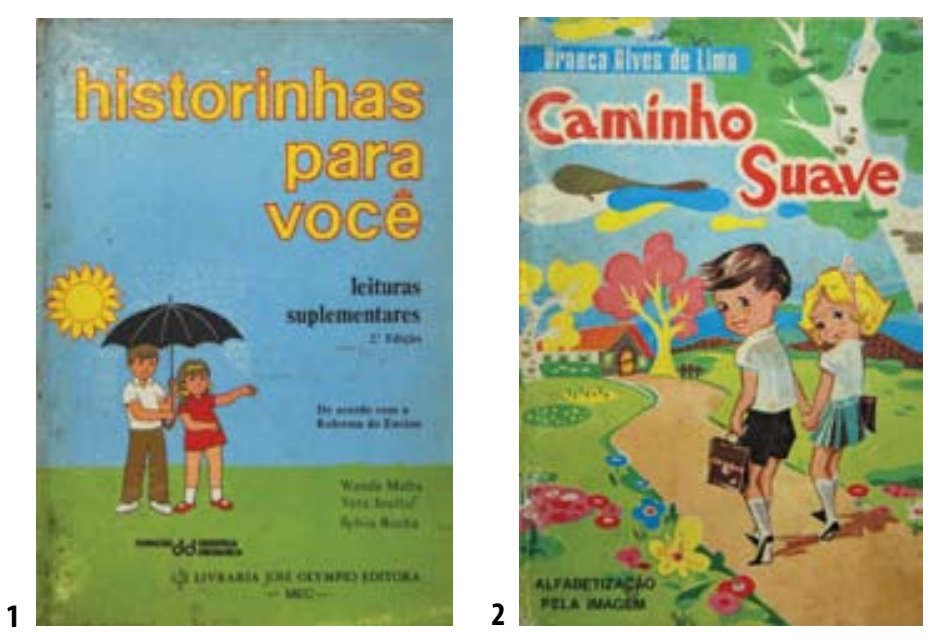

3
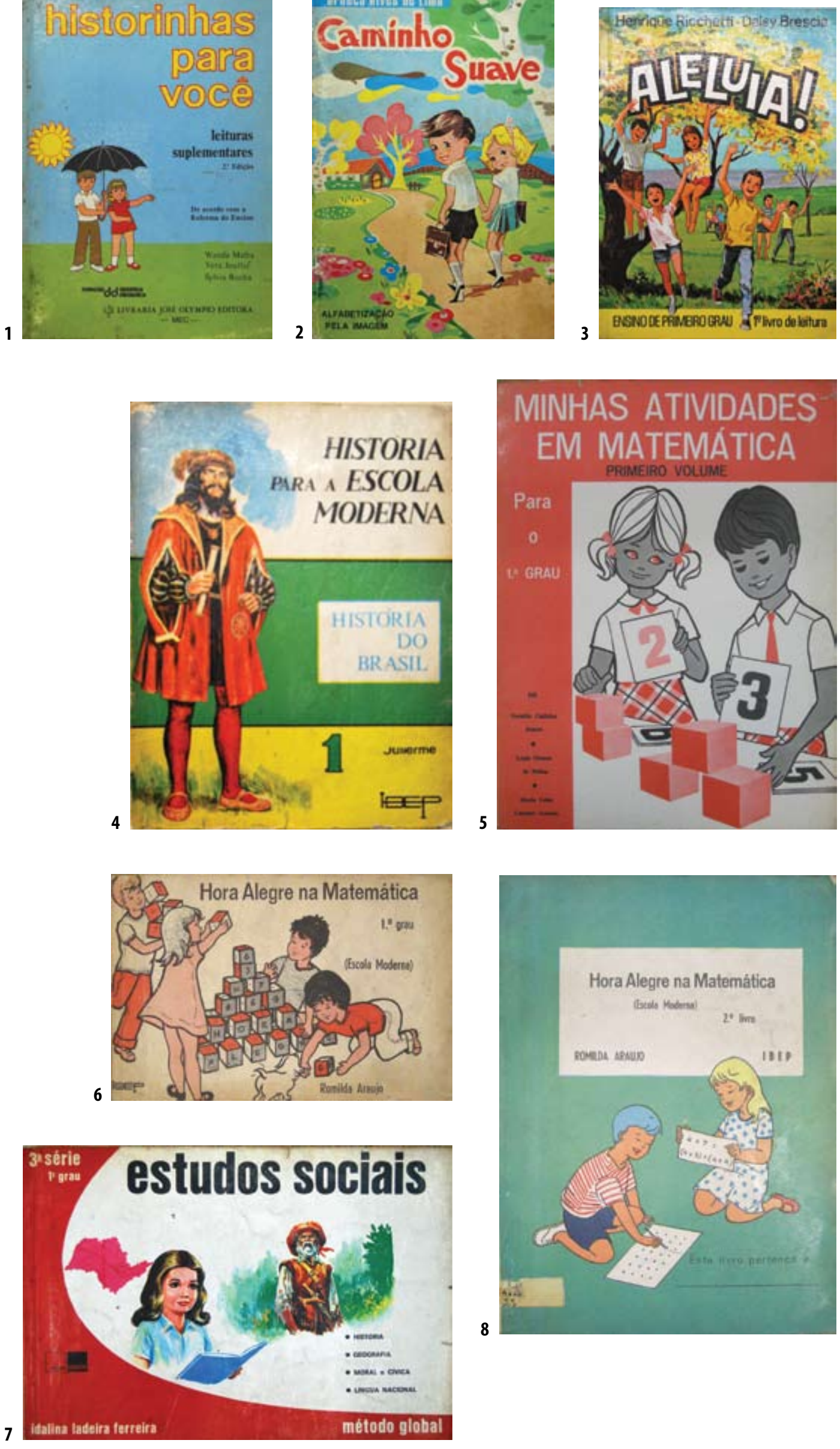

1. ${ }^{\circ}$ grupo: capas "tradicionais" ou "vernaculares"

1 Historinhas para você: leituras suplementares. Wanda Mafra, Vera Joullié, Sylvia Rocha. José Olympio/INL, 1973. 2. ed. $\left(23,0 \times 15,5 \mathrm{~cm}^{*}\right)$

2 Caminho suave. Branca Alves de Lima. C. Suave, 1981. 84. ed. Capa Flávio Pretti. $(23,0 \times 15,0 \mathrm{~cm})$

3 Aleluia: 1. ${ }^{\circ}$ livro de leitura. Daisy Bréscia, Henrique Richetti. Nacional, 1973.

Capa João Gargiulli. $(20,6 \times 14,8 \mathrm{~cm})$

4 História do Brasil: História para a escola moderna, v. 1. Julierme de Abreu e Castro. Ibep, 1971. Capa Eugenio Colonnese. $(27,0 \times 20,0$ $\mathrm{cm}$ )

5 Minhas atividades em Matemática, v. 1. Maria Luiza Campos Aroeira, Lygia Gomes de Padua, Geralda Caldeira Soares. Lótus, 1973. 3. ed. Capa Maria Helena. $(28,0 \times 21,0 \mathrm{~cm})$

\section{Hora alegre na}

Matemática, 1. grau.

Romilda Araújo. Ibep,

197?. $(14,0 \times 21,5 \mathrm{~cm})$

7 Estudos Sociais. Idalina Ladeira Ferreira. Saraiva, 1973. $(19,0 \times 27,5 \mathrm{~cm})$

8 Hora alegre na Matemática, 2. livro. Romilda Araújo. Ibep, 197 ? $(29,0 \times 21,5 \mathrm{~cm})$

* As capas foram reproduzidas mantendo a proporção entre os formatos. A ausência de menção à autoria de muitas capas deve-se à prática de não se creditar o trabalho de profissionais internos das editoras. 
nização não atinge toda a indústria gráfica. Velhas máquinas continuaram a operar por muito tempo ainda (CAMARGO, 2003, p. 123 e 126). Na verdade, a demanda por modernização veio principalmente dos setores mais avançados da indústria cultural, as revistas de massa e principalmente sua publicidade, embora a indústria de livros também tenha pressionado por maior automação e velocidade.

No caso da visualidade dos livros escolares, máquinas mais rápidas e melhor qualidade de impressão não implicariam automaticamente renovação de linguagem, pois esta dependeria principalmente do interesse dos editores em promovê-la. Ao que parece, a maioria deles não viu a necessidade de dotar o livro escolar de uma linguagem diferenciada da então praticada pela indústria livreira didática tradicional e supostamente identificada com a cultura escolar.

Isso pode ser observado no uso limitado de imagens e na qualidade visual e material dos livros, que será herdada por parte da produção no início da década de 1970. No caso das capas, é flagrante a visualidade de décadas anteriores, particularmente evidenciada no uso de ilustrações e não de fotografia, na ilustração em linguagem de traço típica do uso de clichê tipográfico ou de superfície não reticulada própria da litografia assim como no lettering dos títulos realizado à mão, tarefa do próprio ilustrador capista, ou por composição tipográfica. Ou seja, correspondem à sobrevivência de uma visualidade criada pela indústria gráfica nas cinco primeiras décadas do século passado, e aparecem principalmente em obras destinados à educação básica, a alfabetização e todo o primeiro ciclo do ensino fundamental.

No entanto, essa visualidade corresponde a um gosto construído pela tradição da indústria gráfica brasileira e assimilado por várias gerações. Se a introdução da imprensa e da tipografia manual tradicional, nos moldes da exercida desde o século XVI na Europa, se deu tardiamente no Brasil, os processos gráficos propriamente industriais - tipografia, litografia e aplicação da fotografia à impressão, principalmente - se desenvolveram quase imediatamente após sua invenção nos países de origem (o atraso tecnológico ocorreria depois). É rica a tradição brasileira de produção de impressos, desde rótulos de produtos alimentícios e de outros bens de consumo, passando pela imprensa diária e inúmeras revistas ilustradas, até a própria indústria do livro. Revistas ilustradas como Revista llustrada, A Maçã e Paratodos, contaram com designs sofisticados, e a indústria do livro já nos anos 1920 introduziu as capas ilustradas em cores como recurso de comunicação e atrativo para as vendas, caracterizando o livro como objeto gráfico industrial diferenciado. Monteiro Lobato atuou com essa consciência e a Companhia Editora Nacional é bem o exemplo de empresa que inovou, expandiu e criou padrões gráficos para capas e miolo. (cf. CARDOSO, 2005, p. 164-168)

O que ocorre no caso particular dos livros escolares é que, com algumas exceções, sua produção e desenho não acompanhou e não atingiu os padrões visuais mais elevados de outros meios impressos, como dito anteriormente.

De qualquer forma, essa primeira tendência, com capas bem ou mal realizadas, corresponde a um design hoje chamado vernacular, porque desenvolvido dentro da indústria gráfica e que resultou numa tradição de gosto e numa linguagem socialmente reconhecidas por longo período. 

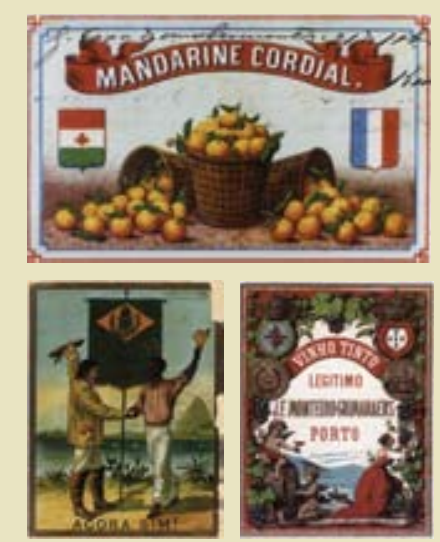

1 Rótulos em litografia do século XIX.

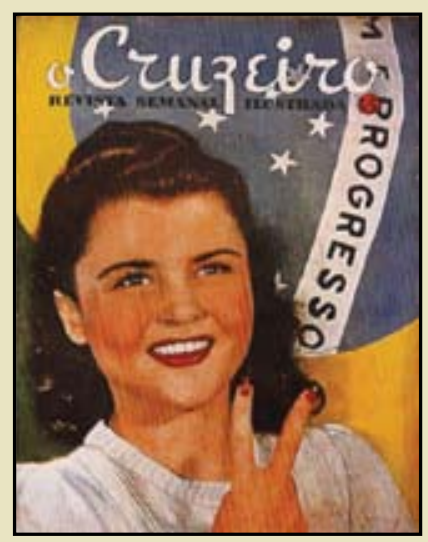

5 Primeira capa fotográfica de O Cruzeiro, de 1942.

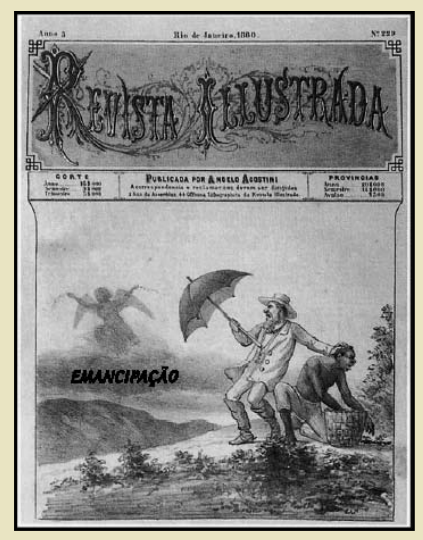

2 Revista ilustrada, de Angelo Agostini, 1898.

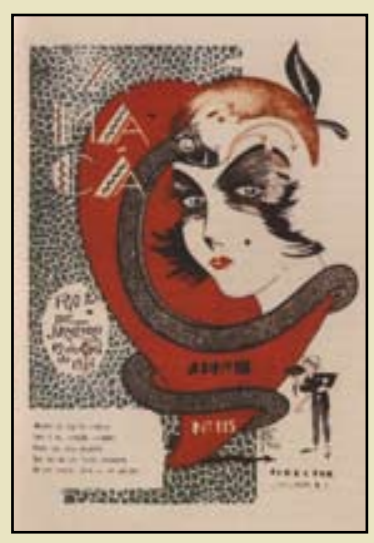

3 Revista A Maçã, de 1924, capa de Guevara.

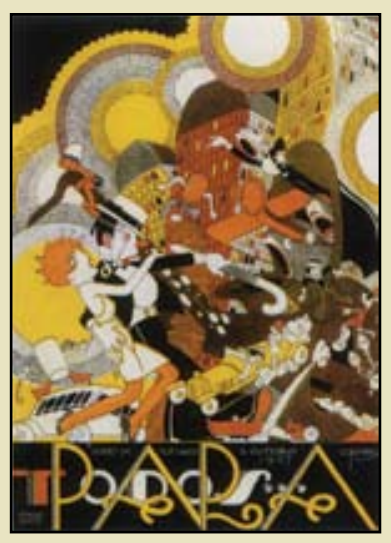

4 Revista Paratodos, design e capa de J. Carlos, de 1928.

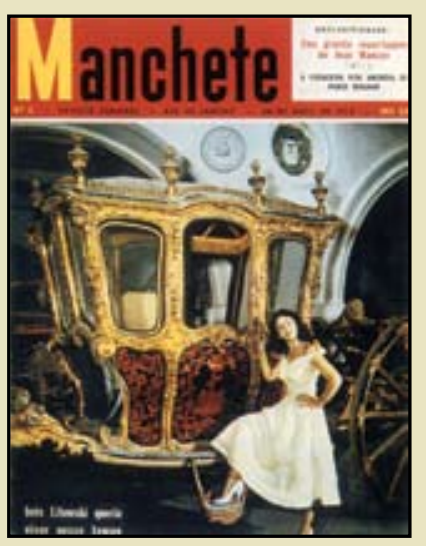

6 Primeiro número da revista Manchete, de reportagens fotográficas, de 1952.
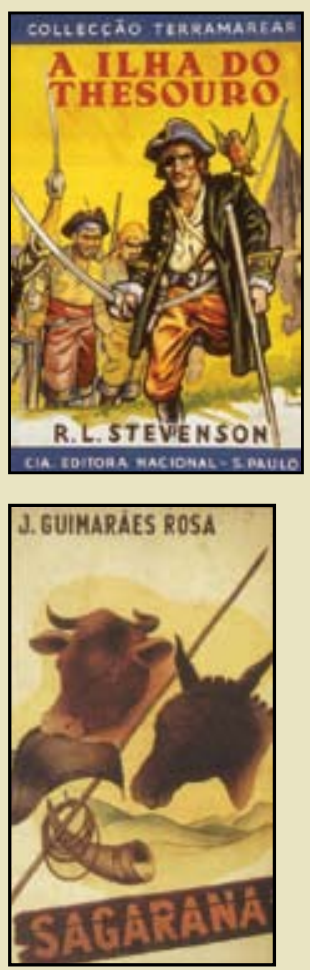

8 Embalagem,

7 Brochuras com

capas ilustradas, décadas de 1930 a 1940

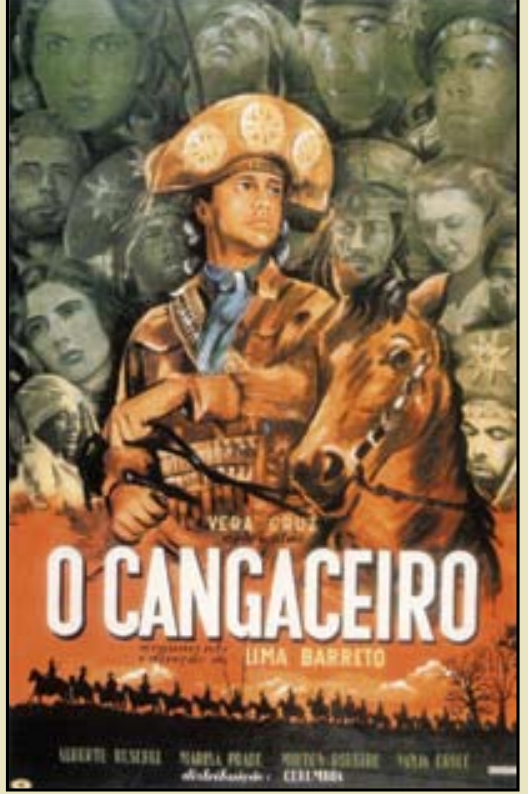

9 Cartaz de cinema, década de 1950. década de 1940.
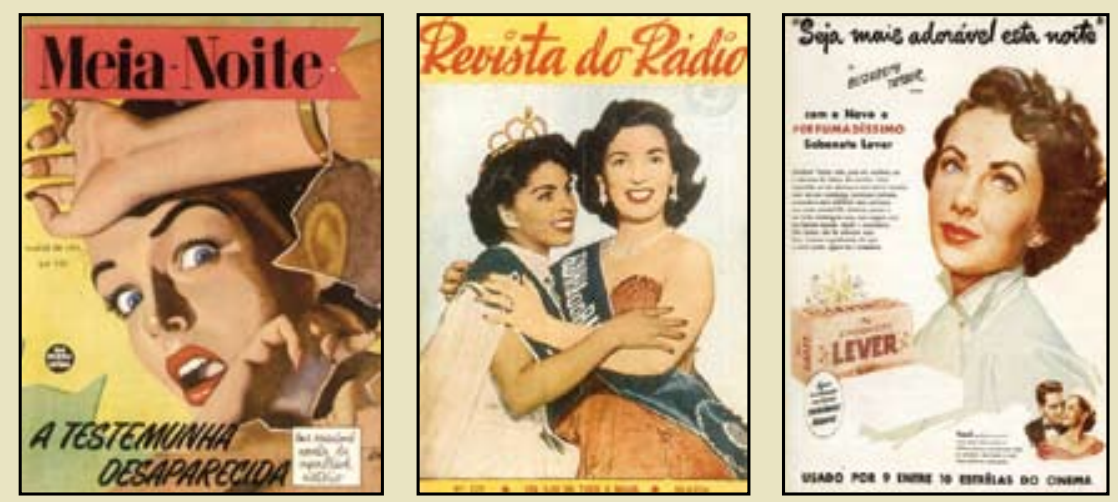

10 Revistas populares e publicidade, década de 1950.
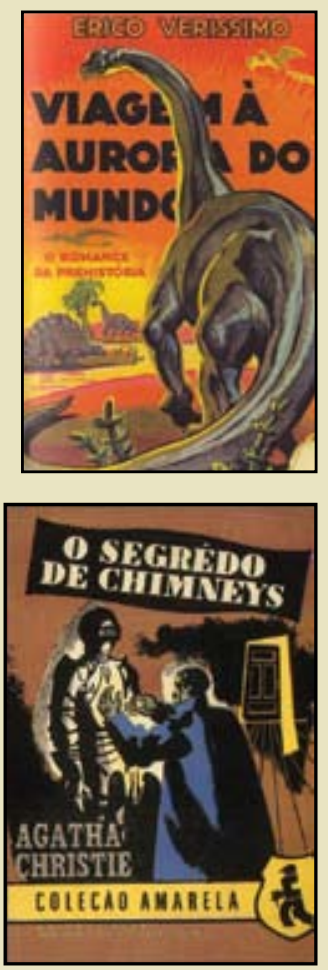

Exemplos da indústria gráfica e cultura de massas brasileira antes da década de 1960. 

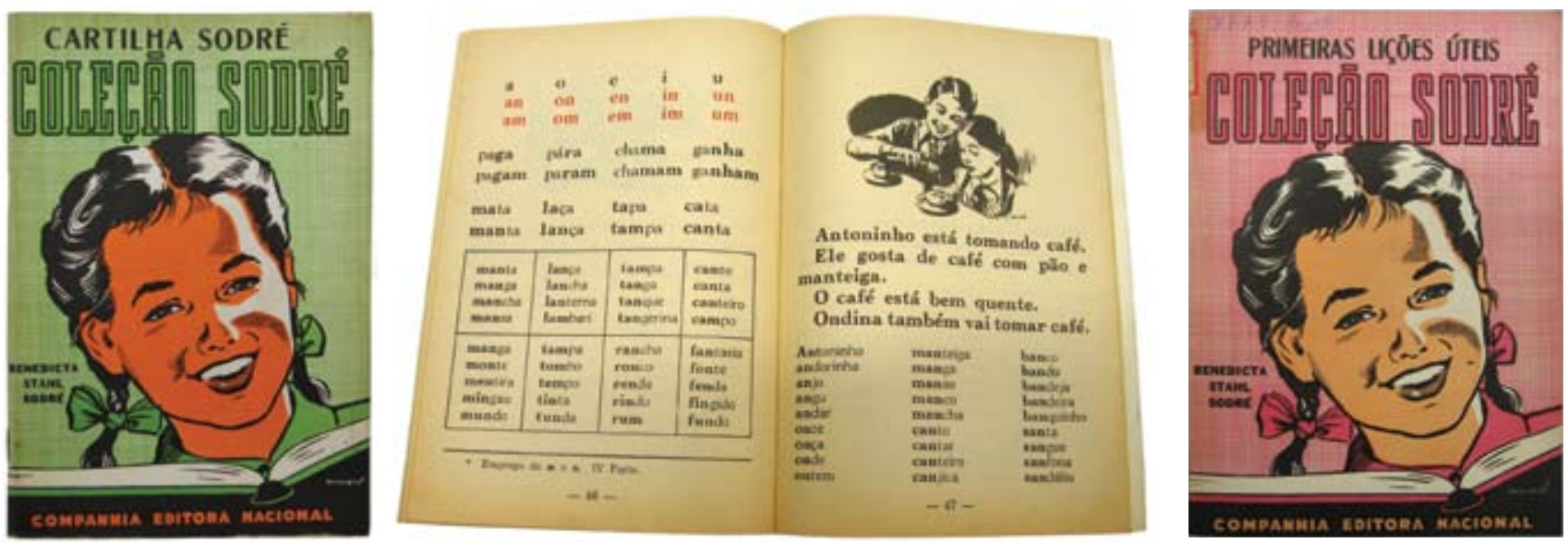

Cartilha Sodré.

Benedita Stahl Sodré. Nacional, 1977. 250. ed. $(18,3 \times 13,0 \mathrm{~cm})($ capa e miolo)

Primeiras lições úteis. (capa)

Design de Augustus.

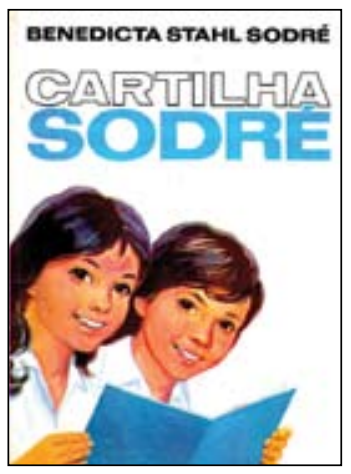

Capa de 1978

$(26,9 \times 19,0 \mathrm{~cm})$.

\section{A Cartilha Sodré}

Entre as capas pesquisadas e enfeixadas nesse primeiro grupo, uma chamou particularmente a atenção - a da Cartilha Sodré, parte da Coleção Sodré, destinada à alfabetização e ao ensino de Língua Portuguesa - por dois motivos. Primeiro, por sua permanência: criada em 1948, manteve a mesma capa até 1977 - 29 anos e 250 edições depois (várias delas, na verdade, reimpressões) —, quando mudou de formato e desenho.

Segundo, por sua qualidade de realização, o que mostra que a visualidade a que chamamos vernacular não só não se opõe à noção de design como projeto para execução industrial, conforme definido anteriormente, como pode também responder pelos quesitos de criatividade, uso planejado de recursos e busca de identificação com seu público.

Por essas duas razões, a capa dessa cartilha é exemplar e reveladora dos aspectos envolvidos na configuração dessa visualidade e sua permanência.

Com relação a esse item, embora a Nacional tenha produzido os livros didáticos mais bem cuidados da década de 1960 e promovido uma renovação no desenho do miolo de alguns de seus títulos e de muitas de suas capas, continuou reimprimindo obras de sucesso com capas antigas. Aceitação por parte do público e pouco interesse em renovar determinadas obras parecem ser os motivos, já mencionados. Mas, para os anos 1970, quando o uso da fotografia era quase uma exigência na publicidade e nas revistas populares e a rede Globo já realizava suas vinhetas cinéticas, do ponto de vista do gosto é bem provável que essa capa já parecesse "antiga" para seu público.

No que diz respeito a seu design, algumas características podem ser ressaltadas. O diagrama da capa de todos os volumes da Coleção Sodré é o mesmo, com esse nome constituindo o verdadeiro título, e a variação cromática do fundo caracterizando cada um. O nome que identifica o volume é composto acima do nome da coleção e com peso menor. Antes que pobre, é uma solução eficaz para a identidade da obra, que não corre risco de ser ignorada. Para o material e o acabamento, a solução também é econômica: simples brochura, grampeada, produto intencionalmente popular e barato de uma editora em que quase to- 
dos os títulos didáticos tinham capa dura impressa em cores.

A simplicidade de linguagem parece ter sido planejada. Não há fundo vazio, todo ele é preenchido com cor pela retícula quadriculada desenhada à mão, mas cada elemento a ser informado tem o seu espaço e nada é perdido ou misturado. A ilustração, de autoria de Augustus, que também ilustrava as obras infantis de Lobato, é muito bem realizada, lembrando a linguagem publicitária introduzida pelas marcas norte-americanas, e pode agradar mesmo nos dias de hoje, sendo possível imaginar como essa menina devia ser simpática para seus pequenos leitores, a quem convidava a partilhar da sua alegria em aprender. $\mathrm{O}$ título principal, também desenhado à mão a partir de modelo tipográfico, seria um tanto rígido para um livro infantil, mas isto é parcialmente amenizado pelo preenchimento colorido.

A solução de capa encabeçada pelo título e com ilustração dominando segue uma tendência já consagrada nas artes gráficas brasileiras e que está presente nos livros de ficção infantil da editora, nas capas de Lobato para a Editora Brasiliense e principalmente em revistas populares. A ilustração a traço preto, preenchida com cor chapada em grandes áreas, corresponde à técnica da litografia anterior ao emprego de retícula fotográfica e da seleção de cores, embora esta já fosse usada na reprodução impressa de fotografia. Além de ser um recurso para compensar a imprecisão de registro, revela a intenção de seguir uma linguagem muito presente nos mais bem realizados designs de livros brasileiros do período, em que não só a ilustração mas também o título eram desenhados à mão pelo mesmo artista. Com uma diferença fundamental: a adoção de um procedimento mais característico do design de revistas, que é o retrato em destaque dirigindo o olhar para o leitor, estabelecendo empatia e identificação mais fortes com ele e salientando o aspecto popular da obra.

Assim, podemos dizer que o design de capa da Cartilha Sodré está perfeitamente alinhado àquele que surgiu e se desenvolveu dentro da indústria do livro e em consonância com a linguagem e a tecnologia da indústria gráfica no Brasil das cinco primeiras décadas do século passado ${ }^{25}$. Seus criadores não eram referidos como designers, pois, embora a palavra já existisse na língua inglesa, a "consciência do design como conceito, profissão e ideologia" só foi surgir no Brasil no final dos anos 1950, com a ruptura que significou a introdução de "um design de matriz nitidamente modernista, filiado diretamente do longo processo de institucionalização das vanguardas artísticas históricas, que ocorreu entre as décadas de 1930 e 1960 em escala mundial" (CARDOSO, 2005, p. 7 e 10).

Independentemente do valor que se dê à linguagem gráfica adotada, os elementos elencados na análise da Cartilha Sodré e que podem ser estendidos a algumas das capas desse grupo são suficientes para se falar em uma atitude e uma atividade de projeto, no que diz respeito tanto aos aspectos de sua produção como aos de consumo, resultando no reconhecimento da presença do design como definido na Parte I, tópico 2.1 deste trabalho.

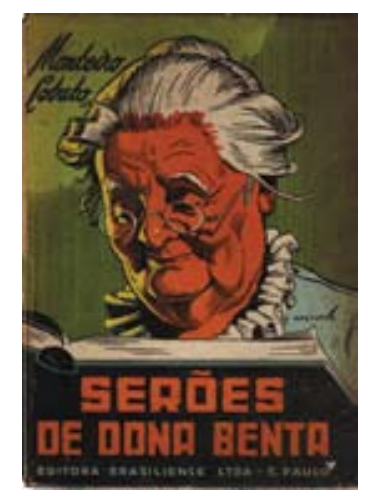

Capa de Augustus para a Brasiliense (196?).
250 design antes do design (CARDOSO, 2005) apresenta detalhada e convincentemente essa tradição da indústria gráfica brasileira e 0 ensaio "0 início do design de livros no Brasil" o faz com relação ao livro em particular. 


\subsection{2. grupo: a visualidade oscilante das capas novas "sem projeto"}

A segunda tendência encontrada na pesquisa é representada por capas realizadas sob influência da indústria cultural florescente na época, com a presença de elementos ou arranjos visuais já tornados comuns em outras mídias ou correspondentes às novas possibilidades tecnológicas da mídia impressa mesma, mas executadas sem reflexão projetual conforme definido na Parte I. Novas linguagens ou estilos de ilustração que migraram dos quadrinhos ou desenhos animados e a presença maior da fotografia diferenciam essas capas das apresentadas no grupo anterior. Também soluções tipográficas "modernistas" encontradas em outros produtos impressos já na década anterior, particularmente em livros para público adulto, aparecem agora em livros didáticos, mas como pura cópia e sem elaboração.

Assim, esse agrupamento é, na verdade, muito vasto e tenta reunir exemplos de design que refletem a influência da visualidade dos novos tempos tecnológicos e midiáticos que se viviam com a expansão da indústria cultural no país, mas sem assimilá-la como proposição cultural e atitude projetual. O resultado dessas propostas revela, em geral, uma defasagem com as linguagens dos meios que as inspiraram e soluções sintaticamente fracas, pobres de invenção e muitas vezes mal executadas.

Parte dessa produção pode ser relacionada à corrente vernacular anterior, como uma continuidade dela, agora realizada com novos meios, mas mantendo a mesma dinâmica de automatismo e ausência de reflexão. Para agravar, esses novos meios não são totalmente dominados pelos planejadores gráficos das editoras, o que contribui para a inconsistência das soluções. Recursos como a fotocomposição, equipamentos de seleção de cores mais precisos para a produção de fotolitos para impressão offset, impressoras mais rápidas e com registro mais preciso podem até ter operadores qualificados que oferecem novas possibilidades de desenho para os produtos gráficos. Mas apenas as maiores agências de publicidade e as editoras de revistas de grandes tiragens investiram em qualificação de pessoal de modo a explorar com proveito essas tecnologias, aliás surgidas para em primeiro lugar atender suas necessidades de expansão e inovação de linguagens.

Com relação às novas editoras surgidas do crescimento sem precedentes do mercado do livro escolar, talvez não tenham mesmo encontrado no mercado de trabalho mão-de-obra suficientemente qualificada e experiente no design e produção gráfica de livros. Isto explicaria a queda de qualidade nesses aspectos em comparação com a produção anterior de uma Nacional, por exemplo, que na década de 1960 chegou a contar com o trabalho de um designer como Eugênio Hirsch. Como não havia escolas de design e apenas uma de artes gráficas, do Senai São Paulo, a formação desses profissionais se dava no interior das agências de publicidade, editoras e gráficas e não foi suficiente para suprir a nova demanda de profissionais.

Ao mesmo tempo que as novas equipes de arte não têm formação nem experiência, os originais dos livros didáticos se tornam mais complexos e o público passa a ter outras referências de gosto na indústria cultural. No primeiro caso, os 

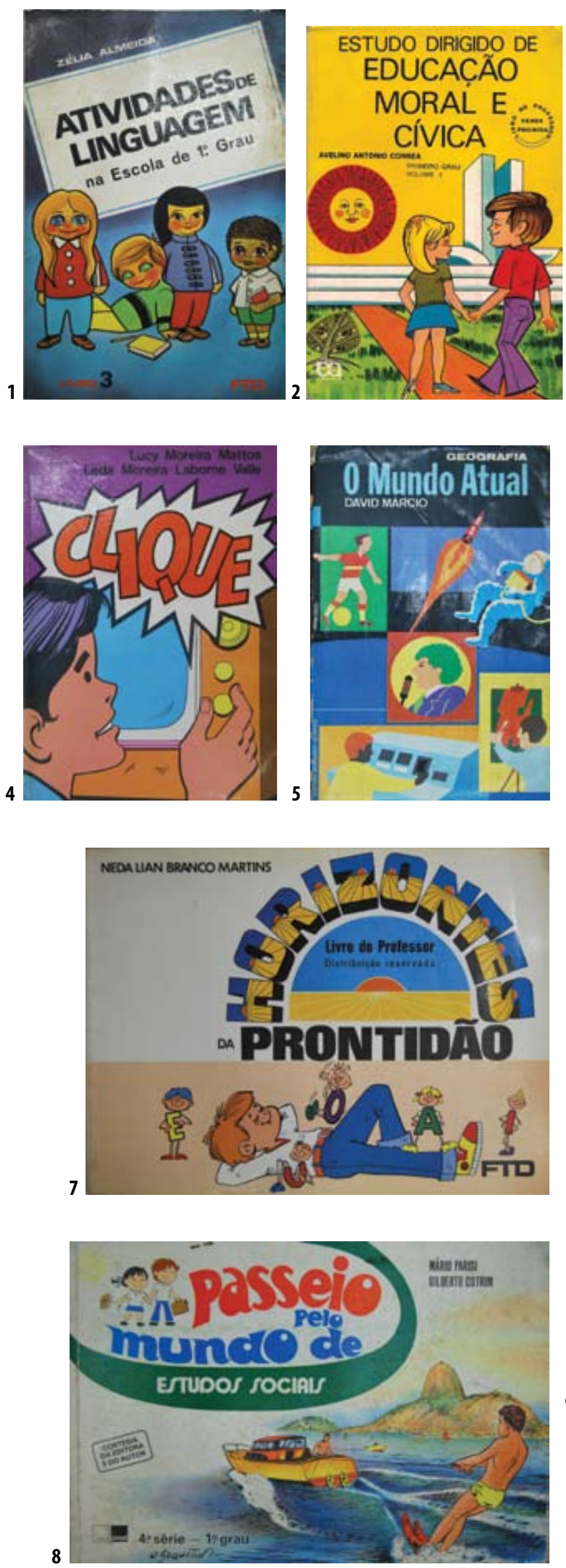
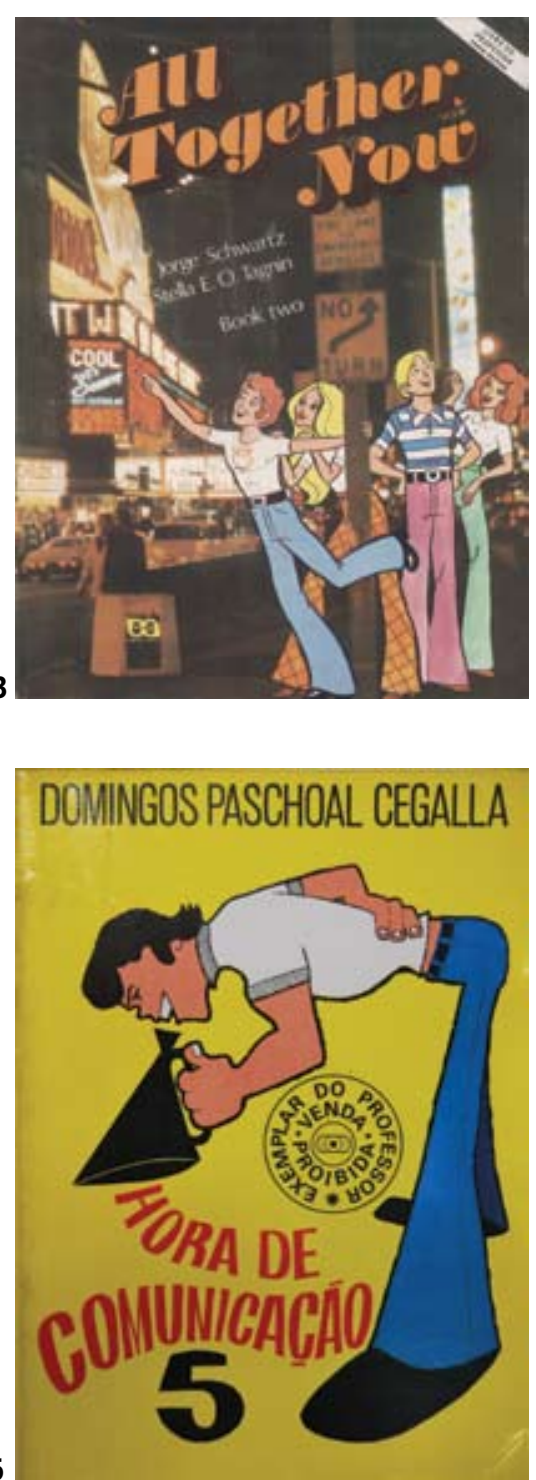

6

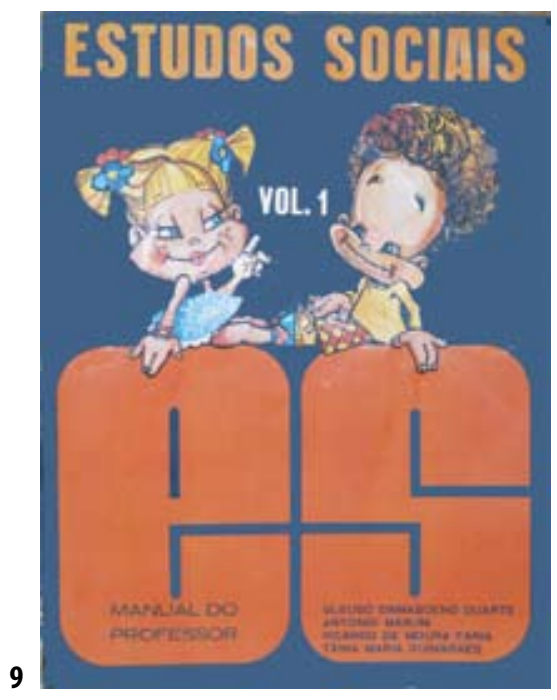

2.ำ grupo:

capas novas

"sem projeto"

1 Atividades de

linguagem. v. 3.

Zélia Almeida. Capa

Edmundo Rodrigues.

FTD, 1974. 2 ed.

$(23,0 \times 15,5 \mathrm{~cm})$

\section{Estudo dirigido de}

Educação Moral e

Cívica. 1. ${ }^{\circ}$ grau, vol. 1.

Avelino Antônio Correa.

Ática, 1979. 4. ed. Capa

Edmundo Rodrigues.

$(22,0 \times 15,0 \mathrm{~cm})$

3 All Together Now.

Book two. Jorge

Schwartz, Stella Tagnin.

Ática, 1977. Capa

Eduardo Carlos Pereira.

$(27,5 \times 20,2 \mathrm{~cm})$

4 Clique. Lucy M.

Mattos e Leda M. L.

Valle. Nacional, 1975.

Ilustrações e capa

Walmir de Oliveira

e Milton Sardella.

$(20,8 \times 15,0 \mathrm{~cm})$

\section{O mundo atual.}

David Márcio. Bernardo

Álvares, 1973.

$(21,0 \times 14,0 \mathrm{~cm})$

6 Hora de comunicação. 5. a série. Domingos Paschoal Cegalla. Nacional, 1980. 44. ed.

Capa Haniel. $(28,0 \times 21,5$ $\mathrm{cm}$ )

\section{Horizontes da}

Prontidão. Neda L. B.

Martins. FTD, 197?.

Capa Claudio Cuellar.

$(20,5 \times 27,5 \mathrm{~cm})$

8 Passeio pelo mundo de Estudos Sociais. 4. ${ }^{\text {a }}$ série. Mário Parisi, Gilberto

Cotrim. Saraiva, 1977.

Capa Osvaldo Sequetin. $(19,0 \times 28,0 \mathrm{~cm})$

\section{Estudos Sociais. v.}

1. Gleuso G. Duarte, Antonio Marum, Ricardo M. Faria, Tânia M. Guimarães. Lê, 1976. Capa e ilustrações Verônica Botelho Pinto e Joyce Silveira Brandão. $(27,7 \times 21,0 \mathrm{~cm})$ 


\section{2. grupo: \\ capas novas \\ "sem projeto"}

1 Educação moral e cívica. Benedicto de Andrade. Atlas, 1978. 5 ed. Capa Pavel Gerencer. $(21,0 \times 14,0 \mathrm{~cm})$

2 Brincando com números. Joanita Souza. Ed. do Brasil, 1979.

$(27,5 \times 21,0 \mathrm{~cm})$

3 Geografia: as grandes paisagens da superfície do globo e o aproveitamento dos recursos naturais. 7. a série. Wanda Jaú Pimentel. Ibep, 197-. $(27,5 \times 20,5 \mathrm{~cm})$

4 Ensino programado de Português. v. 3. Antonio Lages França. Ed. do Brasil, 1972. 24. ed. $(23,5 \times 16,0 \mathrm{~cm}$, capa dura)

5 Toda a química simplificada. L. C. Roque da Silva, Ruy L. Pereira, Victor A. Petrucci, Flavius R. F. Carvalho. FTD, 1978. $(27,5 \times 21,0$ $\mathrm{cm})$

6 Pai, processo autoinstrutivo: Estudos Sociais. 5. a série. Elian Alabi Lucci. Saraiva, 1982. 8 ed. Capa Eunice Toyota $(27,5 \times 21,0 \mathrm{~cm})$

7 Integração social para você. vol. 2. Thereza $\mathrm{N}$. Fonseca, Icles M. Magalhães. Vecchi, 197-. $(21,0 \times 27,5 \mathrm{~cm})$

8 Geografia geral. 2. ${ }^{a}$ série. Manuel C. de Andrade, Hilton Sette. Ed. do Brasil, 197-. Capa Martins Nunes Neto. $(23,5 \times 16,5 \mathrm{~cm})$

9 Estudos Sociais. 5. ${ }^{a}$ série. Celso Antunes. Ed. do Brasil, 197-. Capa equipe EBSA. $(24,0 \times 16,5 \mathrm{~cm})$ livros deixam de apresentar apenas uma seção de exposição teórica seguida de uma sequência de exercícios, com alguns dos temas tratados passando a receber destaque na forma de boxe, por exemplo, recurso importado diretamente das revistas. Como resultado da "pressão" de outras mídias impressas, aumenta o número de ilustrações e de reproduções fotográficas e começam a ser usadas histórias em quadrinhos especialmente criadas para veicular parte do conteúdo em algumas obras. A possibilidade de formatos maiores decorrentes das novas máquinas offset também aproxima o livro do formato mais generoso das revistas. E o abandono do uso de capa dura com a adoção da brochura, mais barata e fácil de produzir, também tornam o livro mais amigável.

Mas essas novas possibilidades não são plenamente aproveitadas no sentido de um livro melhor e mais de acordo com o que o público encontrava nas outras mídias. Um exemplo, com relação ao design do miolo: apesar dos novos formatos, que oferecem um campo maior para distribuição dos materiais gráficos e maior liberdade de layout, e dos recursos de que a fotocomposição dispõe em termos de variedade de fontes e de medidas e possibilidade de quebra da diagramação ortogonal, quase todos os livros para as primeiras quatro séries do 1. ${ }^{\circ} \mathrm{grau}$ são compostos em coluna única, e os destinados às últimas séries, em duas colunas, em medidas padrão para serem diagramados. Não existia projeto gráfico específico para cada obra, e os originais eram fornecidos para serem compostos nessas medidas estabelecidas, com uma fonte serifada — geralmente o Times New Roman — para o texto principal e outra fonte sem serifa - geralmente Helvética — para os exercícios, e em medida menor para o caso de boxes. Os diagramadores recebiam as tiras de texto e faziam o pestape na folha de diagrama adotada pela editora, traçavam os fios necessários e indicavam a aplicação de imagens e cores segundo o padrão adotado pela casa, com poucas variações entre as obras.

Apesar da chamada inovação representada pelo uso de quadrinhos para expor conteúdos, criticada por alguns autores (ver Osman LINS, 1977, p. 133-138), o aspecto é bastante distante dos produtos em que se inspiraram. Isto se deve à qualificação dos ilustradores, nem sempre os mais dotados, que tinham de reproduzir uma técnica narrativa e visual que não dominavam.

É interessante uma comparação com livros infantis de sucesso do período, que mostra que havia ilustradores excelentes, mas talvez não convidados, não interessados ou talvez não em número suficiente para atender à grande demanda de trabalho que os livros didáticos exigiam.

Nem as obras da Nacional escapam a uma queda geral na visualidade em sua produção da década de 1970, se compararmos com o padrão atingido na década anterior. Sabemos que essa editora, com a morte de seu presidente, Octalles Marcondes Ferreira, e o desinteresse da família pelo negócio, passou por uma séria crise, que resultou numa tentativa frustrada de compra pela José Olympio, seguida do controle acionário pelo BNDE - Banco Nacional de Desenvolvimento Econômico, estatal — com a compra final pelo IBEP, em 1980 (HALLEWELL, cit., p. 382-385), o que talvez tenha resultado numa debilidade da equipe de arte e numa orientação mais fraca com relação à visualidade. A maioria das capas da Nacional 

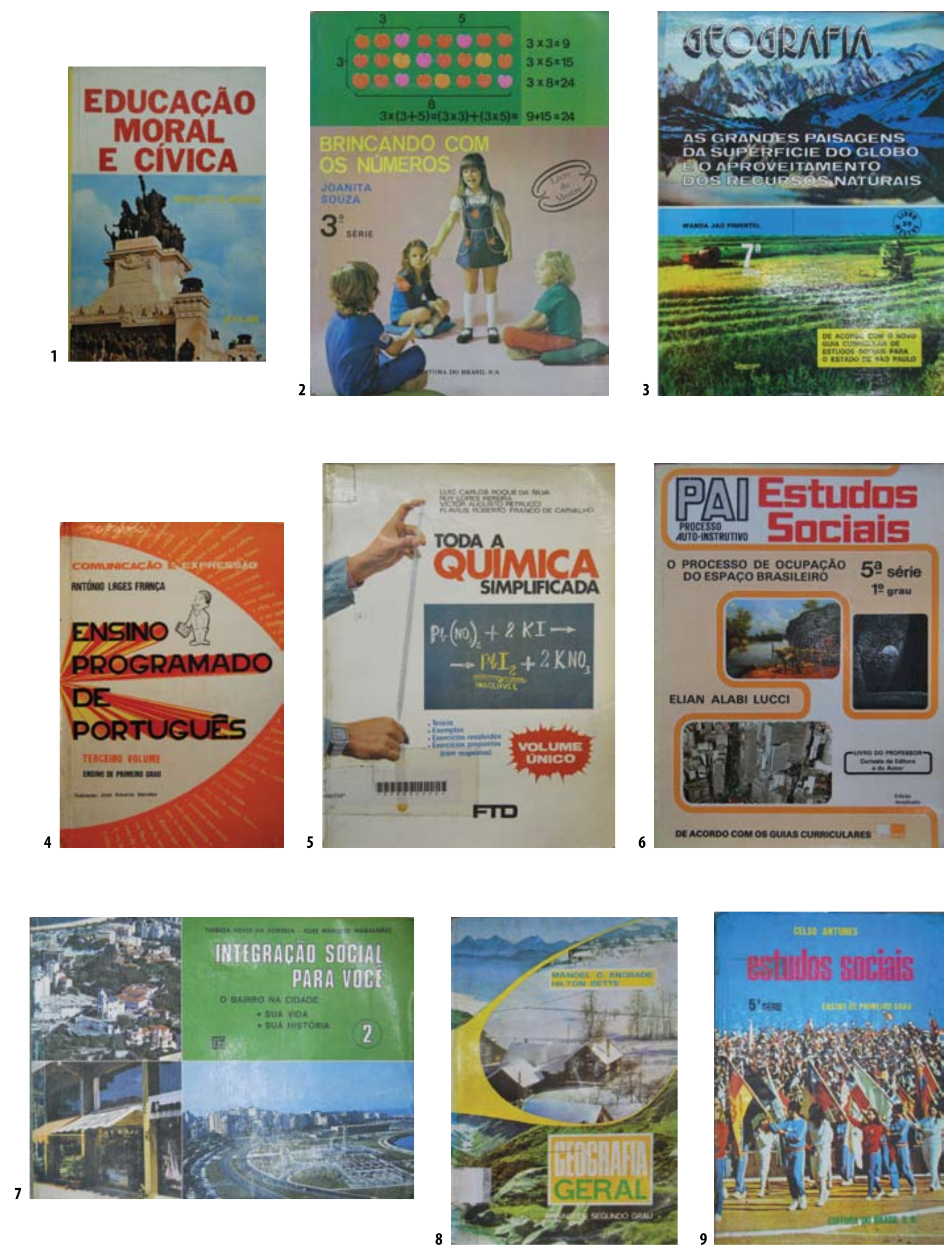
década de 1970 denuncia mesmo uma queda de qualidade visual e se encaixa nesse segundo grupo.

Em geral, essas soluções padronizadas devem-se também ao modelo de produção adotado para o livro didático, em que as editoras buscavam um rendimento e produtividade semelhantes aos de livros mais simples. Ocorre aqui o que Ana Luisa Escorel aponta também na produção de outros tipos de livros:

A diagramação de nossa brochura recebe do editor atenção muito relativa. Atribui-se a ela caráter técnico, sem que essa atitude traduza uma preocupação efetiva com os aspectos propriamente ergonômicos da escrita tipográfica, com a função primordial de "objeto de leitura" do livro, de objeto que se realiza através do texto, exigindo portanto em tese organização gráfica correta e eficiente para poder se exercer, no sentido pleno do termo.

A noção de "técnica" nesse caso parece se aplicar mais a uma tentativa de justificar o descaso estético de que a diagramação costuma ser alvo, do que expressar um cuidado com o aspecto funcional do texto. (ESCOREL, 1974, p. 71)

O tratamento "tecnocrático" dado à diagramação é revelado pelo tipo de profissional dela incumbido, geralmente um funcionário polivalente e não especializado, como aparece nesse depoimento reproduzido pela autora:

— Olha, diagramação não existe, a gente faz isso pela prática. Não existe, não há escolas, a gente vai fazendo porque vê fazer, aprende em jornal, em oficina... Dizem que diagramar é arrumar, é questão de arrumar uma sala ou qualquer coisa... (ESCOREL, cit., p. 73)

Outro fator que determinava uma abordagem "técnica" da diagramação, ignorando o conforto da leitura e a estética da página, era o alto custo do papel de impressão. Tratava-se de ocupar ao máximo a folha, com o alargamento da mancha tipográfica, a redução das margens e o uso de corpos e entrelinhas menores que o recomendado.

Claro que dentro da convencionalidade de projeto vigente é possível encontrar exemplos de livros bem diagramados e ilustrados. São aqueles em que a relação entre texto e imagem baseou-se na escolha de linguagens adequadas de ilustração e fotografia, na pertinência destas em relação aos temas tratados, no ritmo de distribuição e no dimensionamento e posicionamento nas páginas. Mais que apenas o projeto gráfico, é este trabalho de edição de arte baseado na leitura cuidadosa e no planejamento de distribuição dos conteúdos o que pode não só criar o suporte mais adequado e eficaz para o conteúdo didático como oferecer páginas atraentes para o leitor, o que reforça a eficácia pedagógica mencionada.

A situação geral de não se tratar adequadamente o miolo se manifesta também nas capas. Há aqui um flagrante descuido das editoras com esse que é um fator de atração reconhecido muito antes por parte dos editores brasileiros, inclusive a própria Editora Nacional em outros tempos. É interessante comparar com outros meios impressos a que professores e estudantes tinham acesso na época, para verificar como o livro didático não recebia o mesmo cuidado, ainda que do ponto de vista apenas comercial, no uso da capa como fator de atração para a obra.

Não se pensava em investir nas capas talvez por inexperiência com a atividade editorial, uma vez que os novos editores até há pouco tempo eram apenas 
bem-sucedidos professores e autores. Além de novos no ramo, não contavam com mão-de-obra formada em design e tinham que se apoiar apenas no gosto pessoal, quando sabemos que conhecimento estético e cultura visual são, ainda hoje, restritos praticamente a quem se especializa nos campos da linguagem visual.

Assim, não podemos deixar de considerar a pouca cultura visual dos novos editores, jovens oriundos das faculdades de letras e ciências humanas ou exatas, mais afeitos às questões de conteúdo e didática das disciplinas, com pouca experiência inclusive com questões editoriais e de texto, e chamados a decidir sobre aspectos visuais e gráficos, sem a necessária informação e bagagem cultural. Do mesmo modo, a própria ausência de tradição do design moderno nessa área editorial e a tardia institucionalização da profissão designer, ainda dependente do desenvolvimento dos recém-criados cursos universitários ${ }^{\mathbf{2 6}}$ e da conquista do mercado por esses profissionais, para não falar na falta de regulamentação (cf. BRAGA, 2005, capítulo 1), não permitira, naquela época, uma referência profissional reconhecida por esse meio editorial.

No já mencionado estudo que faz das capas de brochuras, Ana Luisa Escorel afirma que os editores não sabiam o que era ou não viam necessidade no trabalho de designer e reproduz depoimentos que confirmam essa tese (1974, p. 79-80).

Mas não podemos descartar o possível receio das editoras em gastar mais que do que supunham necessário e o fato de que o livro didático pudesse ser para a maioria dos editores o "primo pobre da literatura", não merecendo maiores cuidados, e o "primo rico das editoras", pela certeza de venda e lucro que propiciava em relação ao investimento feito, como bem definem Lajolo e Zilberman.

Essa situação não é exclusiva do livro didático. Escorel a atribui a uma certa tradição brasileira de "fragmentação" do livro em corpo e revestimento, ao desconhecimento dos editores "do que seja o planejamento gráfico aplicado ao produto industrial" (1974, p. 80). Assim, talvez os editores de didáticos apenas façam um pouco pior o que a maioria dos editores — excetuando a excepcional produção de editoras como a José Olympio, a Ariel, a Schmidt, a Globo, a Civilização Brasileira, a Sabiá, entre outras - já faziam talvez não tão mal.

\footnotetext{
${ }^{26}$ FAUUSP (Faculdade de Arquitetura e Urbanismo da Universidade de São Paulo) em 1962, ESDI (Escola Superior de Desenho Industrial), no Rio de Janeiro, em 1963, FUMA (Fundação Mineira de Arte - Universidade do Estado de Minas Gerais) em 1964, e FAAP (Fundação Armando Álvares Penteado) em 1970.
} 


\section{3. ${ }^{\circ}$ grupo:}

capas "com projeto" 1) a produção interna

\section{Matemática para} a escola moderna. 4. ${ }^{a}$ série. Scipione di Pierro Neto. Ibep, 197-. $(21,5 \times 15,5 \mathrm{~cm})$

2 Matemática: curso moderno. v.1. Alcides Bóscolo, Benedito Castrucci. FTD, 1971. $(21,0 \times 14,0 \mathrm{~cm})$

\section{Iniciação à química} orgânica moderna. Geraldo C. Carvalho. Nobel, 1973. Capa Joel Link. $(22,5 \times 15,5 \mathrm{~cm})$

4 Estudos sociaise naturais. $4 .^{\circ}$ e $5 .^{\circ}$ anos. Maria de Lourdes Gastal. FTD, 1980. 43. ed. $(22,0 \times 15,3 \mathrm{~cm})$

5 História geral. Paulo Gomes, Vera L. Gomes. Lê, 1979. Capa Jan Deckers. $(23,0 \times 16,0 \mathrm{~cm})$

6 História das sociedades. Rubim de Aquino, Francisco Alvarenga, Denise Franco, Oscar C. Lopes. Ao Livro Técnico, 1979. Capa Nelson Ayres. $(24,3 \times 17,4 \mathrm{~cm})$

7 Biociências: seres vivos, morfologia, taxonomia. José Manuel C. Rodrigues, Wladimir T. de Moraes. Nacional, 1978. Capa Haniel. $(26,0 \times 19,0 \mathrm{~cm})$

8 História geral. v. 2. Antonio José Borges Hermida. Nacional, 1979 , 2. ed. Capa Almir Gomes. $(27,5 \times 20,5 \mathrm{~cm})$

9 Geografia. 5. a série. Julierme de Abreu e Castro. Ibep, 1979. Capa Rodolfo Zalla (?). $(27,5 \times 20,5 \mathrm{~cm})$

10 Alô, Matemática. 2. a série. Irene Torrano Filisetti. Nacional, 1975. Capa José Roberto Martins. $(28,0 \times 21,0 \mathrm{~cm})$

\subsection{3. grupo: as capas "inovadoras" ou "com projeto"}

Em um terceiro grupo podem ser reunidas as capas que, mais ou menos relacionadas às linguagens das mídias, do design modernista ou mesmo do design da indústria do livro mais tradicional, oferecem soluções com maior consciência do potencial e função da linguagem visual para a comunicação com o público. Não se trata de uma única tendência, mas de manifestações diversas, sem relação direta entre si, mas que expressam a presença tanto das linguagens mais estabelecidas no melhor livro brasileiro, como das linguagens e da cultura visual mais recentes do período. O que as caracteriza e permite reuni-las num mesmo grupo é que nelas é perceptível a prática e a competência projetual, no sentido estabelecido no tópico 2.1 da Parte I.

Em relação à tendência anterior, foi encontrado um número bem menor de exemplos, o que parece confirmar que a visualidade do livro didático, na década de 1970, foi produzida "sem projeto".

\section{A produção interna das editoras}

Um primeiro bloco desse grupo reúne a realização interna das editoras, geralmente com pessoal próprio que produz design competente e adequado às demandas dentro da tradição do livro escolar e do livro em geral num novo momento e com os novos recursos, mas também o trabalho de profissionais contratados que trabalham dentro desses parâmetros. O que a diferenciaria da tendência vernacular são as referências à mais recente manifestação de comunicação de massa no período, mas também ao design modernista que se impunha em outras áreas. Essas duas fontes exerciam uma influência que se evidenciava na linguagem gráfica dessas capas, particularmente:

- na valorização da tipografia, com diversidade, novos desenhos de fonte, soluções baseadas exclusivamente em seu uso e no texto construído como imagem;

- na modernização na linguagem das ilustrações, que acompanham as encontradas nas revistas e nos quadrinhos mais recentes;

- nos diagramas assimétricos e dinâmicos.

Não é possível chamá-las capas diretamente modernistas ou desenhadas conforme o design editorial das revistas e da publicidade, pois a ligação delas com esses designs é ainda tênue, de "segunda mão", e elas não são produzidas com a mesma metodologia e dentro da mesma esfera cultural e profissional. O que se percebe, no entanto, é a propriedade com que os elementos dessa linguagem são assimilados, ou seja, existe uma qualificação profissional envolvida, o que não ocorre no grupo das capas "sem projeto". Há também elementos de linguagem, como cores chapadas e desenho de traço, que corresponderiam a momentos anteriores da tecnologia gráfica e do design, mas que não foram apropriados segundo uma linguagem modernista pela produção vernacular e que agora vão aparecer como um eco atrasado mas com presença modernizadora do livro escolar. Estas características já podiam ser notadas em parte da produção da Nacional na década de 1960. 

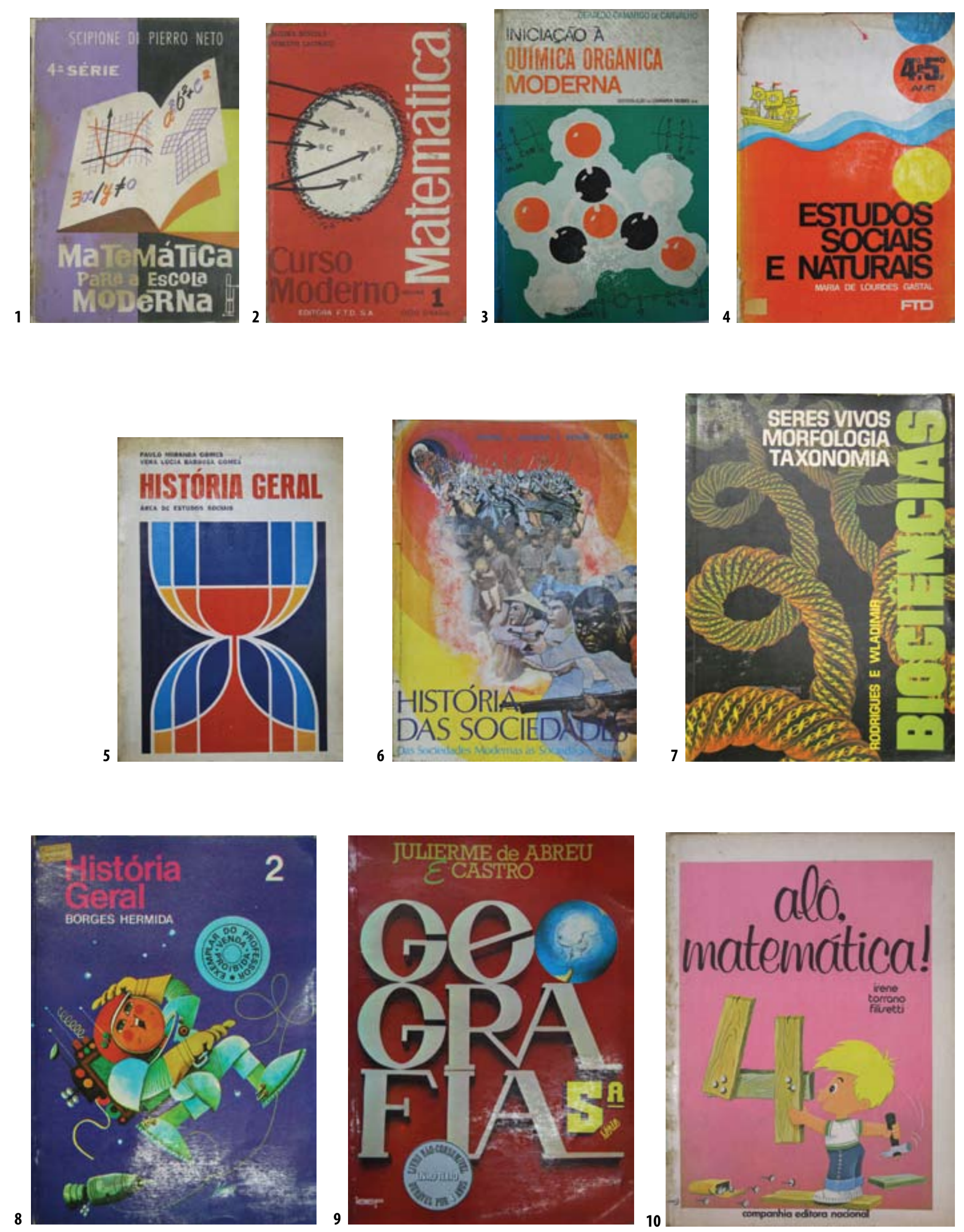

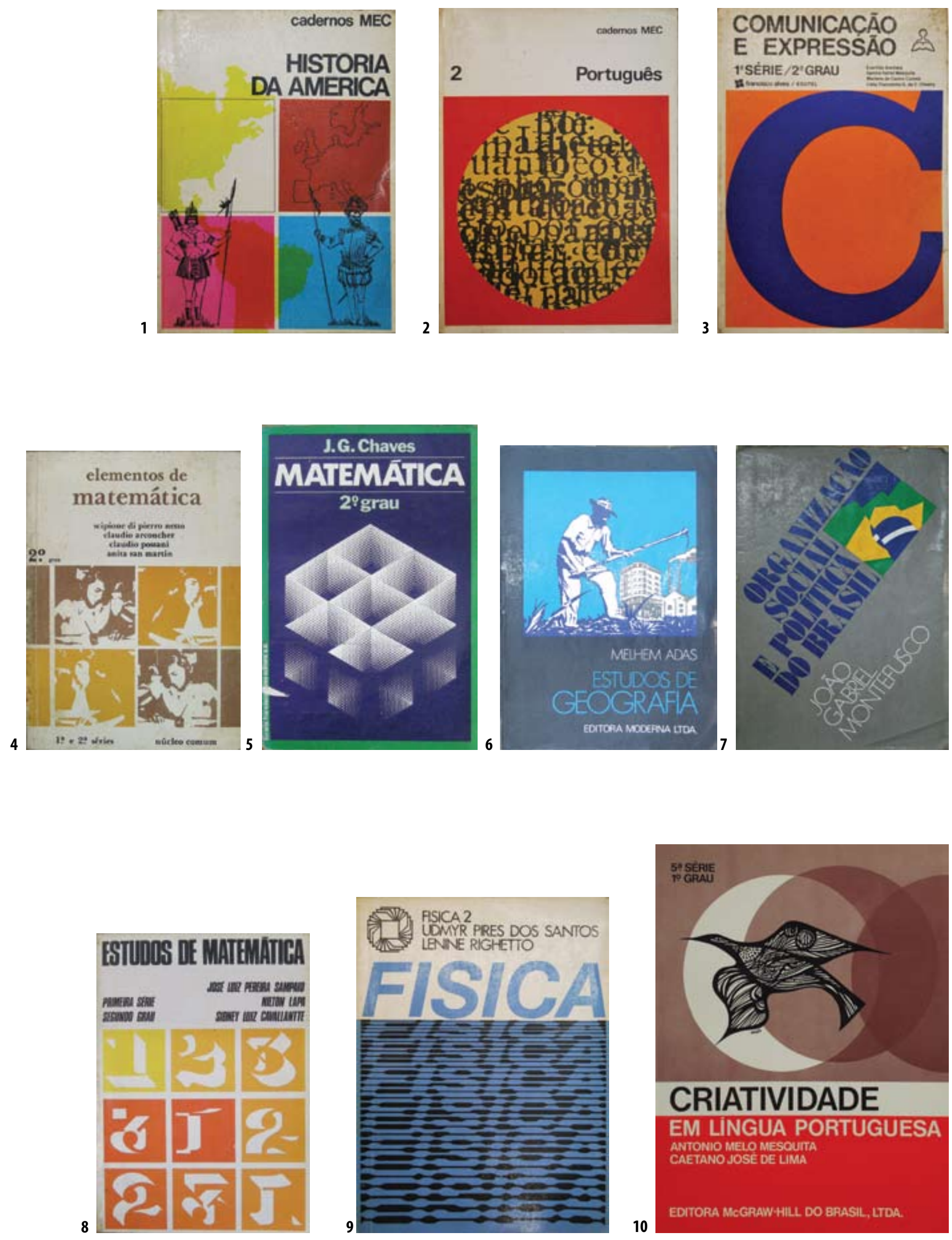


\section{As capas modernistas}

Um segundo bloco reúne as capas produzidas pelos designers com formação acadêmica ou evidente filiação modernista, contratados pelas editoras que começam a reconhecer a presença desse segmento profissional e a contribuição que podem dar para a configuração e o resultado comercial de seu produto. Há aqui desde a contratação descontínua e episódica de designers por parte das editoras, até a prestação sistemática de serviços por um escritório que pioneiramente se especializou no segmento escolar.

Um exemplo do primeiro caso é o trabalho de Odiléa Toscano para a obra Criatividade em Língua Portuguesa, da Editora McGraw-Hill do Brasil, publicada em 1978. Sua contribuição não se restringiu às capas, mas abarcou todo o projeto gráfico, paginação e ilustrações, um conjunto concebido para integrar texto e imagem num processo único de aprendizagem, como a própria designer pôde explicitar nas orientações pedagógicas que redigiu, dirigidas ao professor, para que este explorasse didaticamente a visualidade do livro. Este parece ser um exemplo único até então, e provavelmente raro até hoje, de participação de um designer na conceituação do projeto editorial-didático de uma obra escolar. Porém seu trabalho se distingue do design modernista estrito por se apoiar na força expressiva e pessoal da ilustração. (GOLDCHMIT, 2008).

O segundo caso é o da Editora Atual, que chama um designer com formação acadêmica, Sylvio Ulhôa Cintra Filho, para criar a identidade visual da empresa e fazer todas as capas, constituindo a resposta mais sistemática ao problema da atualização da linguagem de capas de livros didáticos baseada no design modernista.

É preciso lembrar que, desde o final dos anos 60, obras publicadas pelo MEC contavam já com o trabalho de designers de filiação modernista, acompanhando a tendência de implantação da cultura do design a partir das demandas do Estado e das empresas públicas. Mas é na década de 1970 que o processo de implantação do design modernista se aprofunda, com o poder público e as empresas privadas de grande porte, incluindo multinacionais, recorrendo à primeira geração de designers formados nas escolas de arquitetura que tinham essa especialidade no currículo e nas primeiras escolas de desenho industrial.

Se a afirmação do design modernista e sua cultura se dá inicialmente junto às grandes empresas e organismos estatais em função do próprio desenvolvimento econômico do país, sua expansão para setores mais periféricos e economicamente menos influentes ocorre, não raramente, a partir de relações e conhecimentos pessoais. Assim é que essa vertente, considerada erudita, e sem uma tradição de produzir design de massa, termina por ser chamada a fazer presença também num objeto com uma história de desenho considerado convencional e acomodado.

O início do design gráfico moderno no Brasil está relacionado diretamente ao movimento da arte concreta dos anos 1950, como seu tributário quase imediato. Os designers que formaram os primeiros escritórios nas décadas de 1950 e 1960 e que se dedicaram principalmente à criação de sinais de identidade corporativa começaram como artistas plásticos participantes do abstracionismo geométrico,
3. grupo: capas "com projeto" 2) as capas modernistas

1 História da América. Delgado de Carvalho. Cadernos MEC, 1971. Artes finais André Gonçalves. (23,0 x 17,0 $\mathrm{cm}$ )

2 Português. Cadernos MEC, 1971. Capa Gianvittore (Gian) Calvi. $(23,0 \times 17,0 \mathrm{~cm})$

3 Comunicação e expressão. 1. ${ }^{\text {a série. }}$ Evanildo Bechara e outros. F. Alves, 1977. Capa Dia Design $(23,0 \times 16,0 \mathrm{~cm})$

\section{Elementos de}

Matemática. $2 .^{\circ}$ grau.

Scipione di Pierro Neto e outros. Scipione, 1979?. Capa DBM/Marco Antonio Valiengo. $(21,0 \times 15,0 \mathrm{~cm})$

5 Matemática. $2 .^{\circ}$ grau. João Gabriel Chaves. F. Alves, 1975. Capa AG Com. Vis. e Arquitetura. $(23,0 \times 15,0 \mathrm{~cm})$

6 Estudos de Geografia. Melhem Adas. Moderna, 1974. Capa Jorge Hondo. $(21,5 \times 15,0 \mathrm{~cm})$

7 Organização Sociale Política do Brasil. João G. Montefusco. Moderna, 1977. Capa Ricardo Van Steen. $(21,2 \times 14,8 \mathrm{~cm})$

9 Física 2. Udmyr P. dos Santos, Lenine Righetto. Atual, 1977. Capa Sylvio Ulhoa Cintra. (24,0 x 18,0 $\mathrm{cm}$ )

8 Estudos de Matemática. 1. a série, $2 .^{\circ}$ grau. José L. Sampaio, Nilton Lapa, Sidney Cavallantte. Capa Ricardo Van Steen. Moderna, 1977. $(21,0 \times 15,0 \mathrm{~cm})$

10 Criatividade em Língua Portuguesa. 5. a série. Antonio M. Mesquita, Caetano J. de Lima. Capa Odiléa Toscano. McGraw-Hill, 1975. $(27,5 \times 20,5 \mathrm{~cm})$ 
270 abandono da arte como representação propugnado pelas vanguardas artísticas que tiveram sua expressão na formação da Bauhaus, foi a condição essencial para a constituição de um design que se propunha como linguagem do produto industrial, que se representa algo é a si mesmo e a seu uso, que não incluía nenhuma dimensão simbólica que 0 transcendesse. A abstração e mais ainda 0 construtivismo eram vistos como uma conquista do pensamento que permitia a criação de formas próprias de uma estética da máquina e que expressou a utopia social do modernismo artístico e arquitetônico em propiciar a experiência estética e artística com o espaço e com os objetos da vida cotidiana, ou seja, o fim da arte como experiência transcendente e destinada a poucos. Isto tudo como consequiência do emprego da razão e da técnica derivada dela para a solução dos problemas básicos do homem, a moradia, o trabalho e o lazer.

$28 \mathrm{Um}$ relato do surgimento e trajetória do design gráfico moderno no Brasil é feito pelo próprio Alexandre Wolner no ensaio-depoimento "A emergência do Design Visual" em AMARAL,1998. A atividade dos outros designers citados pode ser vista em A herança do olhar: o design de Aloysio Magalhães, de João de Souza Leite, e Design total: Cauduro Martino 1967-1977, de Celso Longo. que, tendo suas bases na arte construtiva das vanguardas artísticas europeias das três primeiras décadas do século XX, contestavam o caráter representativo da arte essencialmente figurativa, em alguns casos de cunho regionalista, do primeiro modernismo brasileiro. ${ }^{\mathbf{7}}$

A proposição básica do construtivismo é a criação de objetos, artísticos ou não, "a partir da articulação de elementos plásticos essencialmente autônomos e livres de carga representativa [...], que tenderiam a cores puras ou essenciais, à forma geométrica e a vínculos racionais ou racionalizáveis a partir de relações simples e precisas" (STOLARSKY, 2006a, p. 191), e o manifesto do movimento concreto paulista Ruptura previa a aplicação prática desses princípios não só na arte e na comunicação visual mas também na produção industrial.

A quase simultaneidade do surgimento da arte concreta e do design gráfico modernista é dada por uma série de eventos que inclui também a introdução do próprio ensino do design e da profissão designer no Brasil. O Instituto de Arte Contemporânea (IAC) do MASP, que só durou de 1951 a 1953, tinha como referência de ensino o Instituto de Design de Chicago, por sua vez tributário da Bauhaus, escola fundada em 1919 pelo arquiteto Walter Gropius, que teve como professores artistas como Wassili Kandinsky, Paul Klee e Josef Albers, entre outros, e fechada em 1933 pelos nazistas. A Bauhaus constitui a matriz do design modernista, de seus conceitos e do próprio ensino do design no mundo.

Mesmo tendo durado pouco, o IAC foi responsável pelo início da carreira de alguns designers, como Emilie Chamie e Stella Aronis, e teve como aluno Alexandre Wolner, que, por sua vez, também cursaria a Escola Superior da Forma de UIm, na Alemanha. Esta escola, que procurou retomar a experiência da Bauhaus na Europa, foi fundada e teve como primeiro diretor o suíço Max Bill. Ex-aluno da Bauhaus, Max Bill era um dos maiores nomes da arte concreta e teve grande influência no debate artístico brasileiro desde sua viagem ao Brasil em 1941 e com o prêmio de aquisição que obteve na I Bienal de Arte de São Paulo, em 1951, pela escultura Unidade tripartida, hoje no acervo do Museu de Arte Contemporânea da USP.

A Escola de Ulm foi o modelo para a criação da primeira escola de design no Brasil, a Escola Superior de Desenho Industrial no Rio de Janeiro (ESDI), que teve como professor Alexandre Wollner, e para a criação das sequências de Programação Visual e de Desenho Industrial da FAUUSP, cursadas por Ludovico Martino, que também foi aluno do IAC, e João Carlos Cauduro, que, junto com Wollner e Aloísio Magalhães, foram responsáveis pelos mais significativos sistemas de identidade visual no Brasil28.

Esta rápida cronologia tem a função de situar as origens do design modernista no país e a filiação das formas que aparecerão também nos livros escolares. Os nomes citados servem também para referenciar a linguagem das capas produzidas para a Editora Atual pelo primeiro escritório de design a se especializar no livro didático, desde a década de 1970. Seu titular, Sylvio Ulhôa Cintra Filho, foi aluno da FAUUSP e iniciou sua carreira no escritório Cauduro Martino.

É de Ulhôa Cintra a coleção escolhida para identificar algumas das características do design modernista presentes no livro didático. 

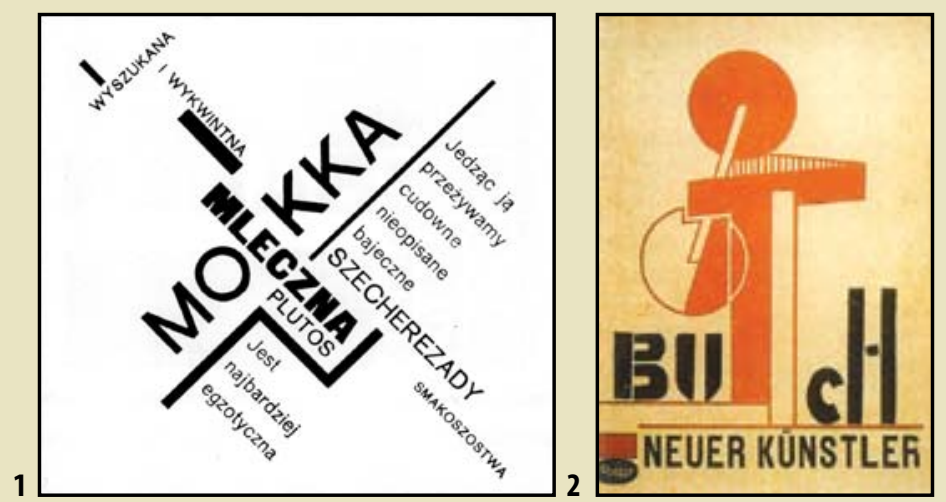

Tipografia construtivista: 1 Anúncio, Henrik Berlewi, 1924. 2 Capa, Lajos Kassak, 1925.
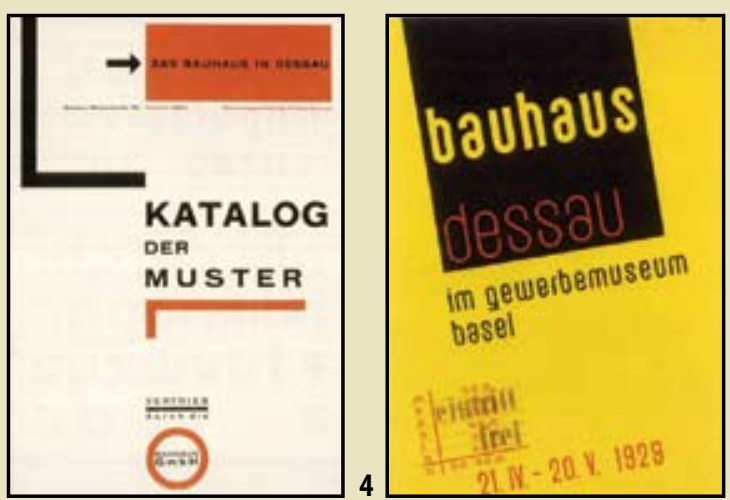

Tipografia elementar: 3 Catálogo da Bauhaus, Herbert Bayer. 4 Cartaz, anônimo, 1925.
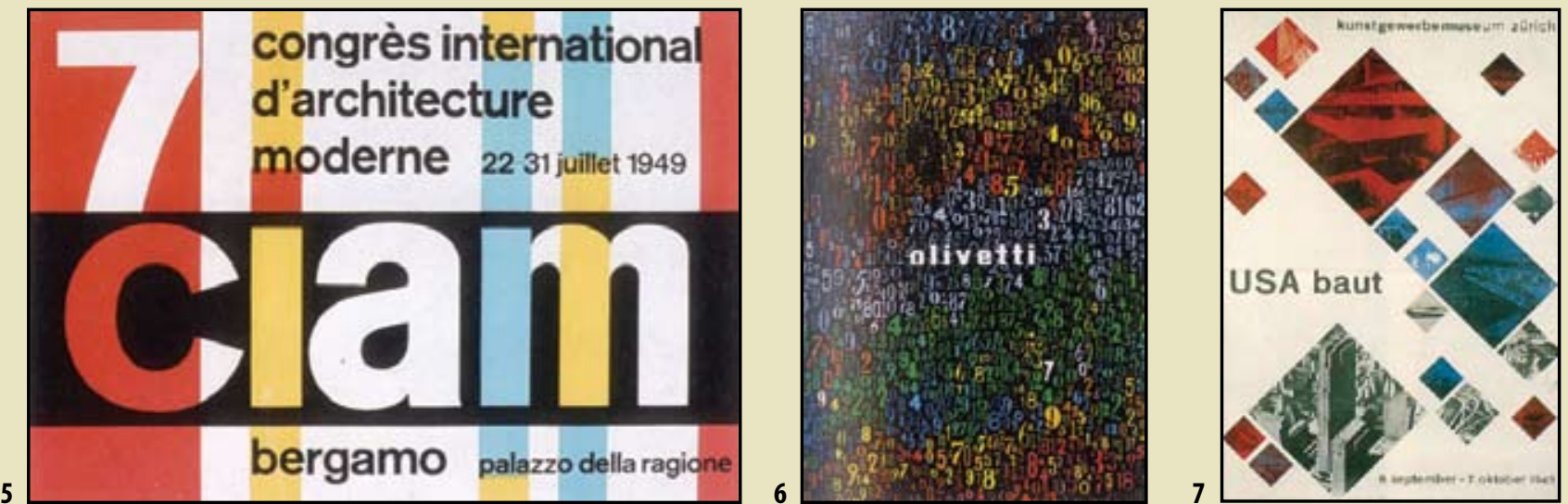

Estilo internacional: 5 Cartaz, Max Huber, 1949. 6 Cartaz, Giovanni Pintori, 1948. 7 Capa, Max Bill, 1948.
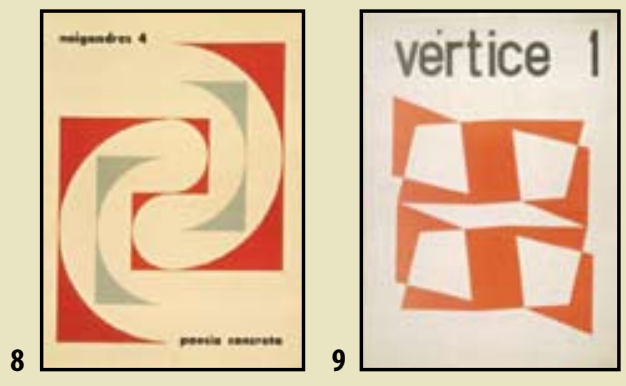

8 Capa, Alexandre Fiaminghi, 1958.

9 Capa, Willis de Castro, 1957.

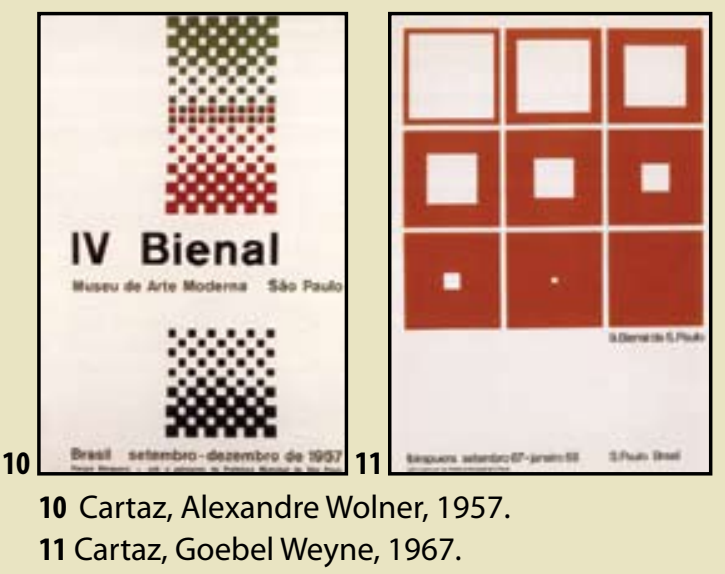

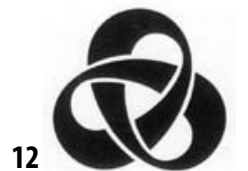
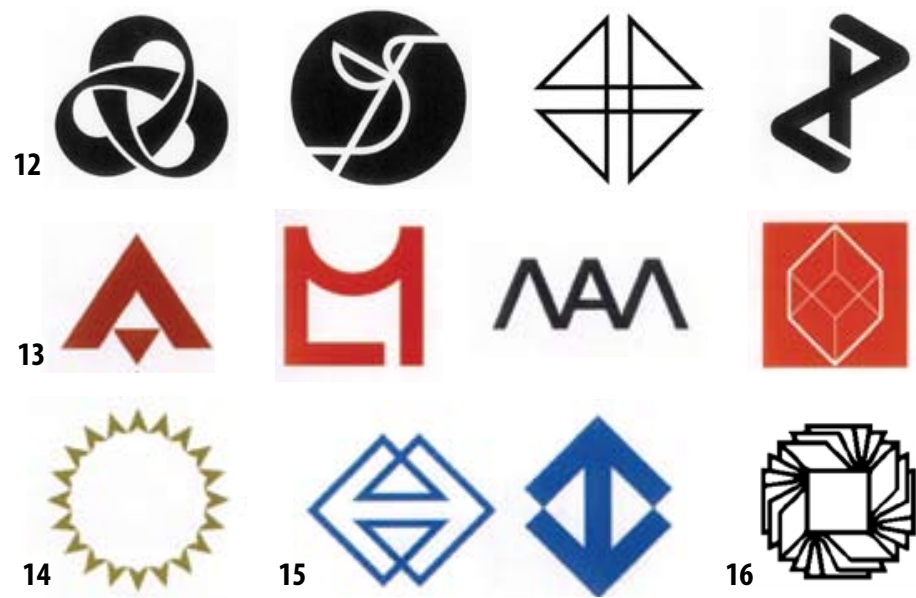

Logotipos, sinais e símbolos:

12 Aloisio Magalhães: Unibanco, 1963; Produtos Beijaflor, 1965; IV Centenário da Cidade do Rio de Janeiro, 1965; Laboratórios Maurício Vilela, 1965.

13 Alexandre Wollner: Atlas Elevadores, 1958; Metal Leve, 1963; Museu de Arte Moderna do Rio de Janeiro, 1963; Probjeto, 1965. 14 Ludovico Martino: FAUUSP, 1958.

15 Cauduro Martino: Metrô São Paulo, 1967.

16 Ulhôa Cintra, Editora Atual, 1969.

\section{Exemplos do design modernista europeu e brasileiro}



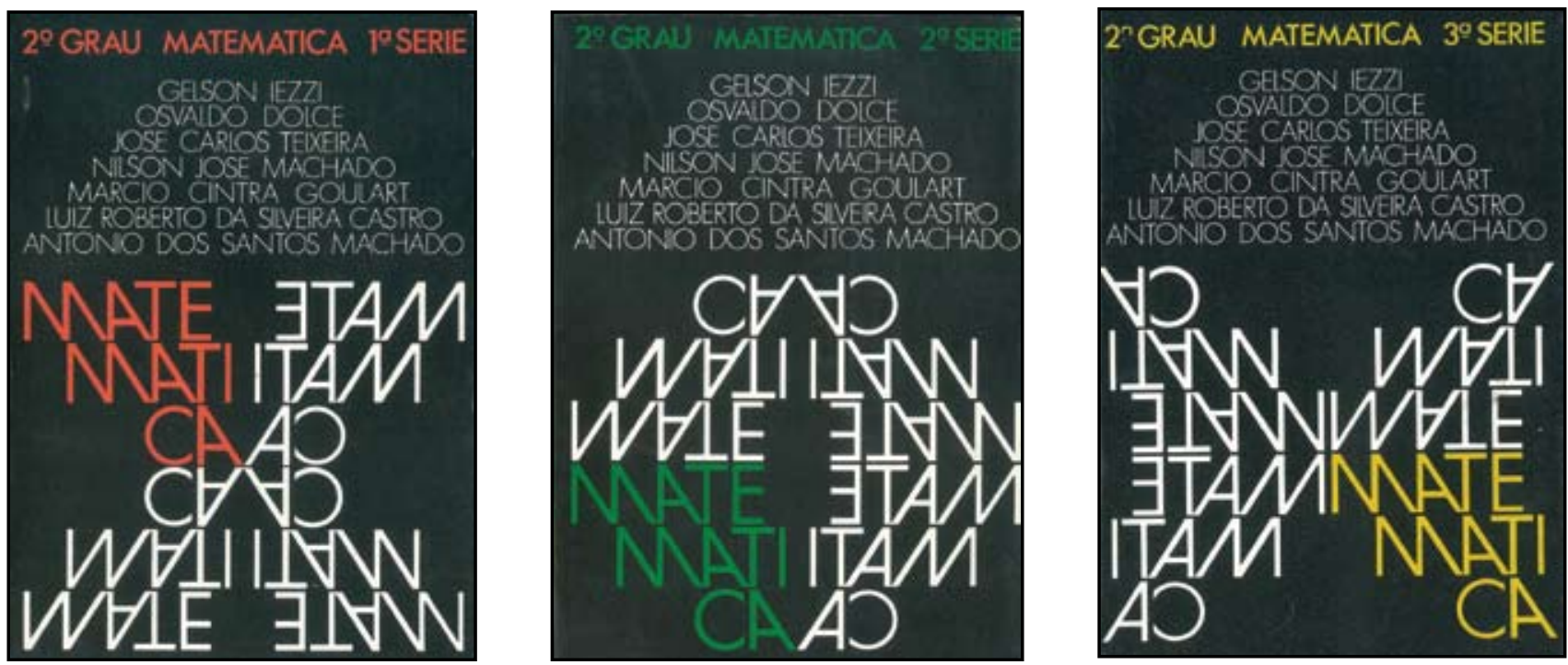

Matemática. $2 .^{\circ}$ grau. Diversos autores. Atual, 1974. Capas de Sylvio Ulhôa Cintra Filho e Roberto Franklin Rondino. $(20,5 \times 15,0 \mathrm{~cm})$

\section{As capas do "Pretinho"}

A partir de laços pessoais estabelecidos pela condição comum de professores em cursinho preparatório ao vestibular na capital paulista, o fundador da Editora Atual, professor de matemática Gelson lezzi, chama Sylvio Ulhôa e Roberto Rondino para conceber as capas da coleção que ajudará a consolidar a editora.

Capas tipográficas eram comuns nos compêndios escolares de capa dura utilizados até os anos 1950, mas tratava-se apenas da composição de títulos centralizados, raramente baseada no equilíbrio dinâmico de textos assimétricos ou tratados como imagem, que caracterizam o design modernista. Fundo preto então, não existia. O apelo dessa solução e quanto ela agradou podem ser medidos pelo apelido que a coleção recebeu de alunos e professores - "Pretinho" — e pela sua permanência, de 1974 a 1990, desmentindo algumas ideias de que um desenho calcado em procedimentos do design modernista - considerados como da "alta cultura" — não pudesse "comunicar".

Nessa capa há uma "ilustração" ou imagem reconhecida como principal na figura formada pela construção geométrico-tipográfica do título, que se relaciona com outras informações de natureza textual — os nomes dos autores e a linha com informação de série, disciplina e nível. Essa figura se transforma em cada capa, a partir de um módulo formado pela composição geométrica do título. Os nomes dos autores são organizados exatamente como um trapézio correspondente à metade de um hexágono ou a parte superior de um octógono, ecoando e compondo-se com a figura geométrica que aparece em cada capa. Por fim, o fundo totalmente preto marca o campo da capa como um retângulo em que tudo, incluindo a linha superior de texto, é percebido como um conjunto de formas e ele mesmo como uma forma que as integra.

Nessa ilustração, a quebra do título em três linhas e o preciso posicionamento delas, aliados à escolha da fonte tipográfica, o Avant Garde Gothic, com seu desenho particular para o $\mathrm{M}$ e o A, permitiram a construção precisa de um dos quadrantes da imagem, que, rebatido sucessivamente, forma a imagem to- 


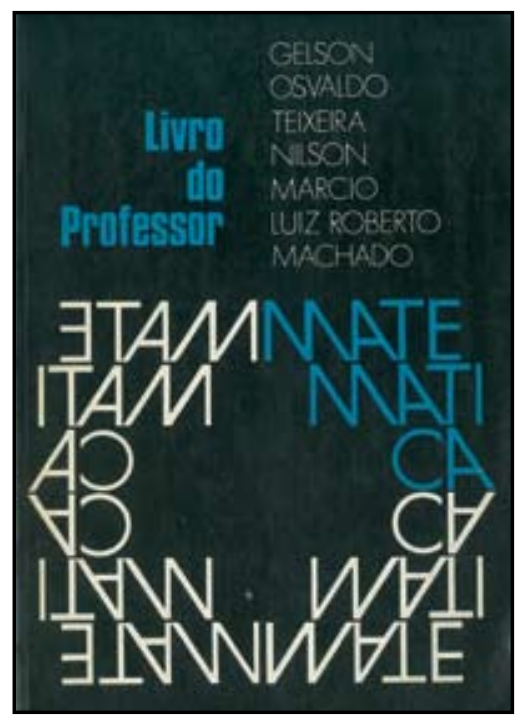

tal. A coincidência das repetições silábicas internas à palavra foi explorada na construção de formas internas à figura principal, como o losango central formado pelas hastes do A, que se repetem nas hastes do $\mathrm{M}$ ou no desenho integral das letras repetidas espelhadas na capa da 2. ${ }^{\text {a }}$ série por exemplo.. ${ }^{\mathbf{9}}$

O procedimento construtivo é explicitado pelo destaque cromático de um dos quadrantes/título em cada uma das capas. $\mathrm{O}$ percurso que eles fazem pelas quatro capas da coleção, que inclui o manual do professor, com a respectiva cor adotada, servem à identificação de cada volume/série. A modificação da figura, além de propiciar uma imagem diferente para cada série, permite que sempre o módulo colorido que percorre os quadrantes esteja na ordem direta de leitura. As cores primárias (amarelo, azul, vermelho) e uma secundária (verde) atestam a filiação modernista da capa. A identidade da coleção é reforçada por esse procedimento gráfico que unifica os volumes pelo uso de um mesmo módulo que forma imagens diferentes para cada capa, relacionando-as a um procedimento ou ideia geral da matemática e não por imagens específicas relacionadas a conteúdos tratados em cada volume ou área dessa ciência.

Nota-se, assim, a adequação entre um procedimento construtivo típico do design e da arte construtiva e sua aplicação numa obra de matemática, o que resulta na total identidade entre forma e função comunicativa.

A fonte utilizada nesse desenho, a Avant Garde Gothic, tem a mesma regularidade geométrica da Futura, de Paul Renner, exemplo da tipografia racionalista: espessura constante das hastes, letras redondas baseadas no círculo perfeito. No entanto, a introdução das sobreposições, ligaduras e composição apertada dão um caráter especial aos textos compostos e os apresentam como formas expressivas. Esse tipo foi criado pelo designer norte-americano Herb Lubalin (19181981) na década de 1960, a partir de seu logotipo para a revista Avant Garde, com o propósito de tratar o texto como imagem, mostrando que o desenho abstrato das letras significa e informa tanto quanto o conteúdo verbal que elas veiculam. Este é um exemplo do desenvolvimento particular que os designers norte-americanos da chamada Escola de Nova York imprimiram ao modernismo europeu a partir da década de 1940, inserindo na tipografia uma expressividade que não chega a negar as raízes modernas, mas as supera modificando alguns de seus princípios mais essenciais - a neutralidade e a regularidade. ${ }^{\mathbf{3 0}}$

Essas capas, portanto, se têm uma filiação construtiva como ponto de partida, incorporam outra contribuição, que vinha do design editorial norte-americano mais recente, viabilizada pela circulação de novos tipos que a fotocomposição e particularmente as letras transferíveis ofereciam.

${ }^{29}$ A composição precisa do título só foi possível pela liberdade oferecida aos usuários de fontes pelo novo processo de composiçãa a frio, a fotocomposição, e pela criação das letras transferíveis (Letraset) e 0 processo de duplicações fotográficas invertidas.

30 Uma reação à tipografia funcionalista vai se acentuar particularmente nos anos 1960, com o desenho de novas fontes, inspirado em tipos da publicidade do século XIX e começo do XX, negados pela tipografía modernista. Os ensaios "Tipografía norte-americana na década de 1960" e "About Us", de Steven HELLER (2007) apresentam as raízes e as consequências dessa tendência, os principais nomes, suas criações e seus seguidores. Exemplos do design norte-americano da década de 1960, que teve grande influência sobre o design editorial brasileiro, serão apresentados na Parte II deste trabalho. 


\section{3. ${ }^{\circ}$ grupo:}

capas "com projeto" 3) capas do "design de revistas"

1/2 A Terra da gente. Bernardo Issler. Abril Cultural, 1968. Capa e ilustrações Anibal S. Monteiro. $(27,4 \times 20,5 \mathrm{~cm})$

\section{3/4 Cartilha de} Matemática. Adla Neme. Abril Cultural, 1973. Capa e ilustrações Enio Possebon e Walter Ono. $(27,5 \times 20,5 \mathrm{~cm})$

\section{No mundo da} linguagem. v. 2. Magdala Lisboa Bacha. Abril Cultural, 1975. Capa Henrique Martim $(27,5 \times 20,5 \mathrm{~cm})$

6 Frações ordinárias. Adla Neme.

Abril Cultural, 197-. Capa Celio Ribeiro. $(19,0 \times 14,0 \mathrm{~cm})$

\section{Tempo de escola:} cartilha de leitura. Neuza R. Goyano, Nelly de Camargo, Nívia Gordo. Abril Cultural, 1973. Capa e ilustrações Walter Ono, Enio Possebon.

$(23,0 \times 18,0 \mathrm{~cm})$

8 O problema ainda é seu: frações ordinárias para 3. ${ }^{a}$ e $4 .^{a}$ séries. Adla Neme. Abril Cultural, 1973. Ilustrações Terezinha Bissoto. $(27,5 \times 20,5 \mathrm{~cm})$

\section{Tempo de} Comunicação. v. 4. Ada Natal Rodrigues, Arlette Azevedo de Paula. Abril Cultural, 1974. Dupla de páginas ilustrada por Mário Cafiero.

\section{As capas do "design editorial de revistas"}

Um terceiro bloco desse design diferenciado pela existência de projeto é constituído pelas capas referenciadas no design editorial das publicações de massa, principalmente revistas e fascículos colecionáveis. No caso, esse design se deve à entrada direta de uma empresa de publicações de massa no segmento do livro didático, a Editora Abril. Embora tenha sido um experiência de curta duração, expressou de maneira cabal a aplicação da linguagem mais atualizada da comunicação visual dirigida ao grande público, presente nas suas publicações.

Com a formação de sua Divisão de Educação, a Abril Cultural lança já nos anos 1960 seus primeiros livros, prosseguindo na década seguinte com livros, mas principalmente com o Curso Abril Vestibular, de fascículos vendidos em bancas, voltados para as áreas de Ciências Humanas e de Ciências Exatas. Para isso, formou uma equipe a partir de suas redações e departamentos de arte e contratou mais profissionais para completar o quadro necessário. A equipe de arte formada incluiu lonaldo Cavalcanti, Mário Cafiero e outros, que saíram diretamente das revistas, trazendo a experiência, a forma de trabalhar e a visualidade desse tipo de veículo. Assim, nos anos que se seguiram, seus livros apresentavam projeto gráfico, diagramação e ilustração feitos conforme os conceitos de comunicação mais imediata com o leitor que as revistas portavam. Um exemplo são os livros de Matemática, que, a par de se filiarem à proposta pedagógica da matemática moderna, vigente na época, eram visualmente semelhantes às publicações infantis, em particular à revista Recreio.

A história da ilustração e da fotografia no Brasil a partir da década de 1960 está ligada à própria história da Abril e de suas publicações. Para muitos designers e diretores de arte que se projetariam depois, a Editora Abril teria sido a escola de design editorial que não havia no país, formando os profissionais de suas próprias publicações e iniciando aqueles que teriam atuação independente até os dias atuais, como Elifas Andreato, Moema Cavalcanti, João Baptista da Costa Aguiar, Hélio de Almeida, entre outros. Para a história específica do livro didático, das redações da Abril saíram muitos editores e em particular o artista gráfico Mário Cafiero, que viria a atuar na renovação visual dos livros da Editora Ática, objeto da Parte II deste trabalho.

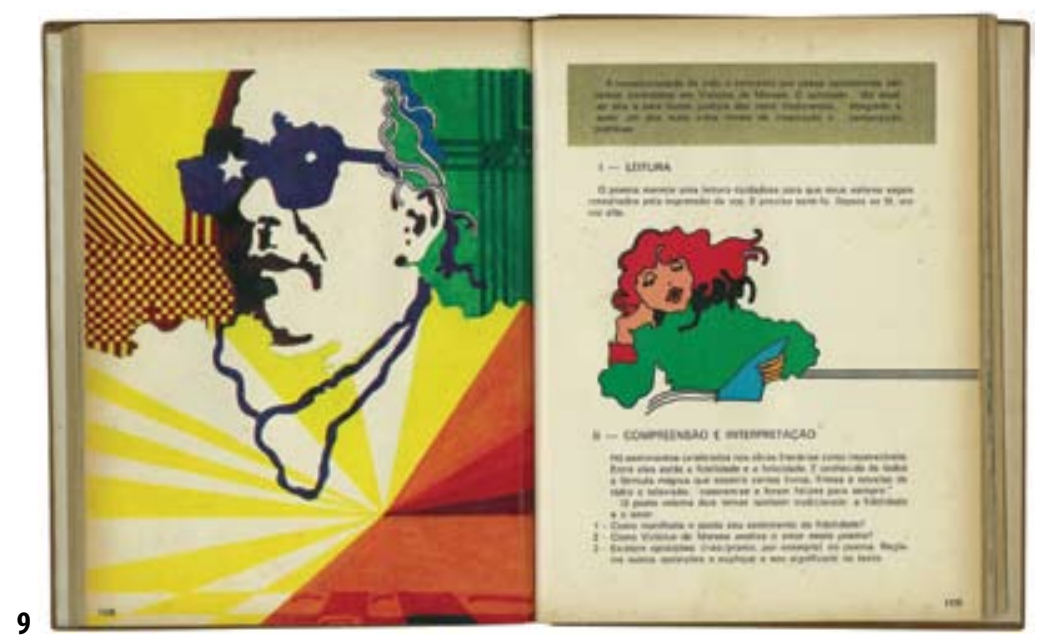



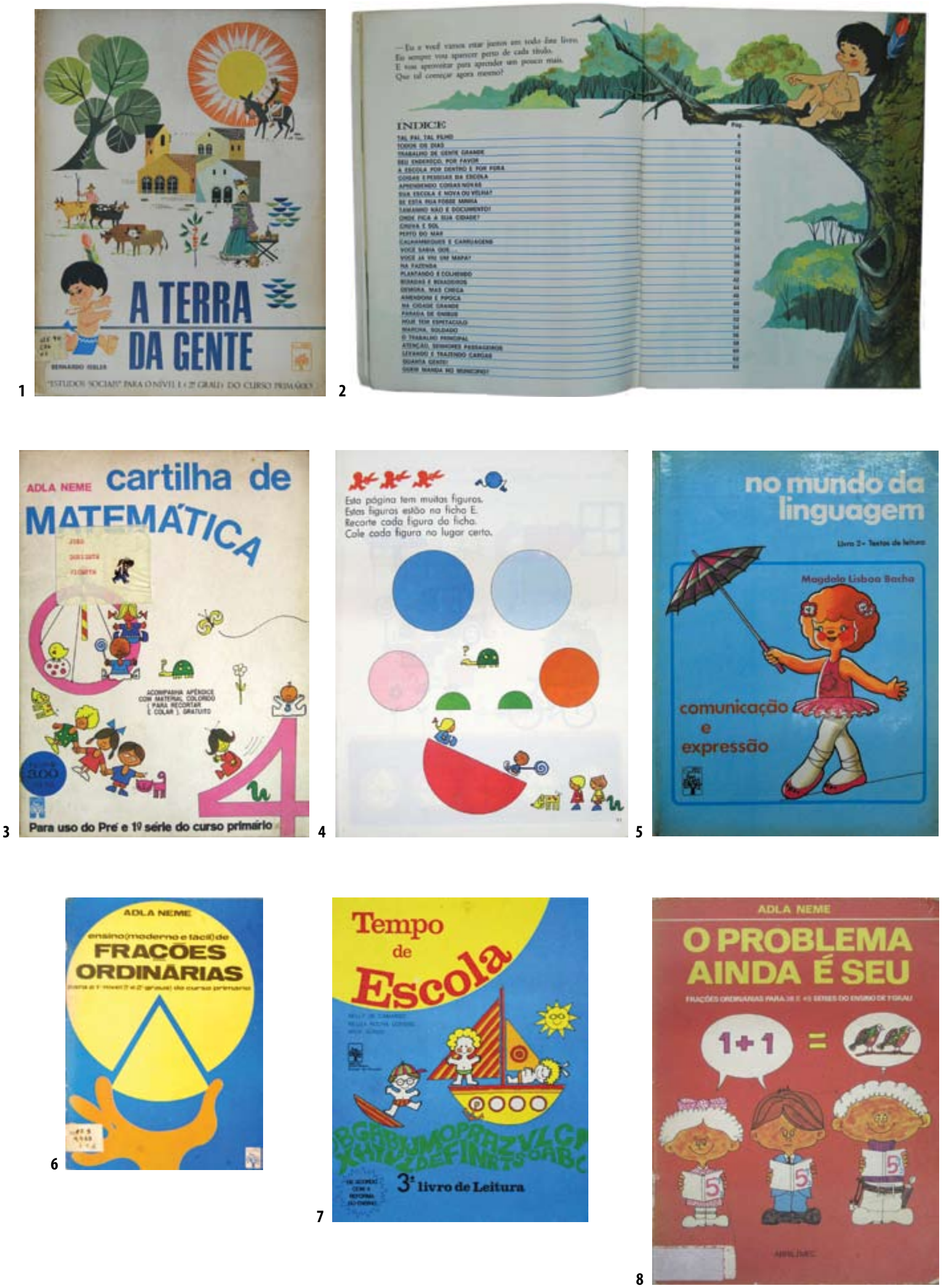


\subsection{Uma conclusão parcial}

O panorama do design de capas de livros didáticos no mercado na década de 1970 nos aponta a prevalência de soluções que não só não correspondiam ao potencial oferecido pelos novos recursos resultantes da modernização tecnológica do setor gráfico como principalmente conflitavam com as linguagens que se afirmavam socialmente em outros segmentos da indústria cultural e da comunicação de massa. Soluções que provavelmente estavam também em desacordo com o gosto de parte expressiva das crianças e jovens sob influência da visualidade a eles dirigida pelos meios de comunicação de massa. E nesse conflito de gosto pode-se incluir os professores, pois, mesmo supondo a existência de uma cultura escolar com uma dinâmica mais lenta, esta não os isolaria como parte do público atingido pelos produtos da indústria cultural.

Esse panorama, em que as exceções confirmam a regra, é o contraponto para o que se apresenta a seguir, a produção de uma editora e seus designers que moderniza a linguagem de capas de livros didáticos no país. Pela importância que alcançará no mercado editorial não apenas didático e pela profundidade com que enfrentou a questão de linguagem gráfica de seus produtos, essa editora terá sua produção analisada mais detidamente. 
PARTE II

A RENOVAÇÃO CONCRETIZADA:

AS CAPAS DA EDITORA ÁTICA 



\section{A EXPANSÃO DA EDITORA ÁTICA E A BUSCA DA ATUALIZAÇÃO VISUAL}

A Editora Ática tornou-se a maior editora de livros do Brasil, tanto em quantidade de títulos em catálogo como em faturamento, na segunda metade dos anos 1980, duas décadas depois da sua fundação, suplantando editoras instaladas havia bem mais tempo no país ${ }^{1}$. Esse fato tem sua explicação nas próprias origens da editora, no tipo de obra a que se dedicou desde o início - o livro escolar — e na capacidade de seus dirigentes em ocupar o espaço aberto não só com a expansão do ensino de massa promovida a partir dos anos 1950 e acelerada nas duas décadas seguintes, mas também com as novas demandas da vida cultural e política do país ocorridas desde então.

A fundação oficial da editora, em junho de 1965, teve como lastro quase dez anos de produção de apostilas para o Curso de Madureza Santa Inês, constituído em 1956. Hoje conhecidos como supletivos, os cursos de madureza surgiram no contexto da política desenvolvimentista de Juscelino Kubitschek tanto para cobrir a dramática falta de vagas no ensino regular oficial como para permitir a conclusão dos estudos interrompidos por um grande número de brasileiros que agora dependiam dessa formação para inserir-se no novo mercado de trabalho que se constituía com a expansão da indústria e dos serviços. Em 1962, o Curso Santa Inês, que já produzia seu material didático na forma de apostilas mimeografadas em substituição aos livros, formou a Sesil - Sociedade Editora do Santa Inês Ltda., para melhorar a qualidade gráfica e atender ao aumento do número de alunos, que já superavam a casa dos três mil. Não só a experiência de ensino do Santa Inês era reconhecida pela eficácia dos resultados nos exames oficiais, mas também seus professores eram conhecidos por suas posições críticas e politicamente avançadas e pelo ambiente de discussão que propiciavam em sala de aula, mesmo após o golpe militar de 1964.² Aproveitando a experiência didática e o reconhecimento de que o curso e seus professores usufruíam, a Ática foi criada inicialmente para difundir comercialmente essa produção didática, para o que foi necessário dar às apostilas o acabamento de livro brochurado protegido por uma capa, preferencialmente ilustrada, que a inserção no mercado exigia.

Assim, um ano depois da fundação, em 1966, a Editora Ática contava já com 23 títulos em catálogo, entre os quais, alguns com relativo sucesso, como Noções de literatura brasileira, de Y. Fujyama e Geografia do Brasil, de Antonio Narvaes. $O$ problema passava a ser o de todas as editoras comerciais: o acesso ao público consumidor, a distribuição e divulgação de seus produtos. Aqui também entrou a percepção e criatividade do principal fundador do Curso Santa Inês e da editora, Anderson Fernandes Dias, que, com base em sua experiência de médico, teria tomado como modelo os promotores de laboratórios farmacêuticos para a constituição de equipes de divulgação junto às escolas e aos professores e a confecção de um cadastro a partir dessas visitas (PAIXÃO, 1995, p. 215).

A par das inovações propriamente comerciais, os livros em si apresentavam novas características editoriais. A primeira delas, a objetividade na apresentação do
1 "Alguns dados numéricos confirmam esta tendência: de 1979 a 1987, a Ática salta da 11. a para a

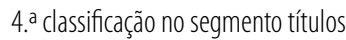
publicados; e entre 1984 e 1987, do 8. ${ }^{\circ}$ para $01 .{ }^{0}$ lugar, no segmento exemplares impressos. Em números absolutos, a editora publica, em 1984, 1.224.000 exemplares e, em 1987, 12.901.000." (BORELLI, 1996 p.114). Além da obra de Borelli, a história da Ática pode ser encontrada em PAIXÃ0, 1995, p. 208-239 e HALLEWELL, 2008, p. 562-565.

2 PAIXÃO (1995) menciona a presença do escritor argentino Jorge Luis Borges em palestra proferida no auditório do curso, em 1970. 

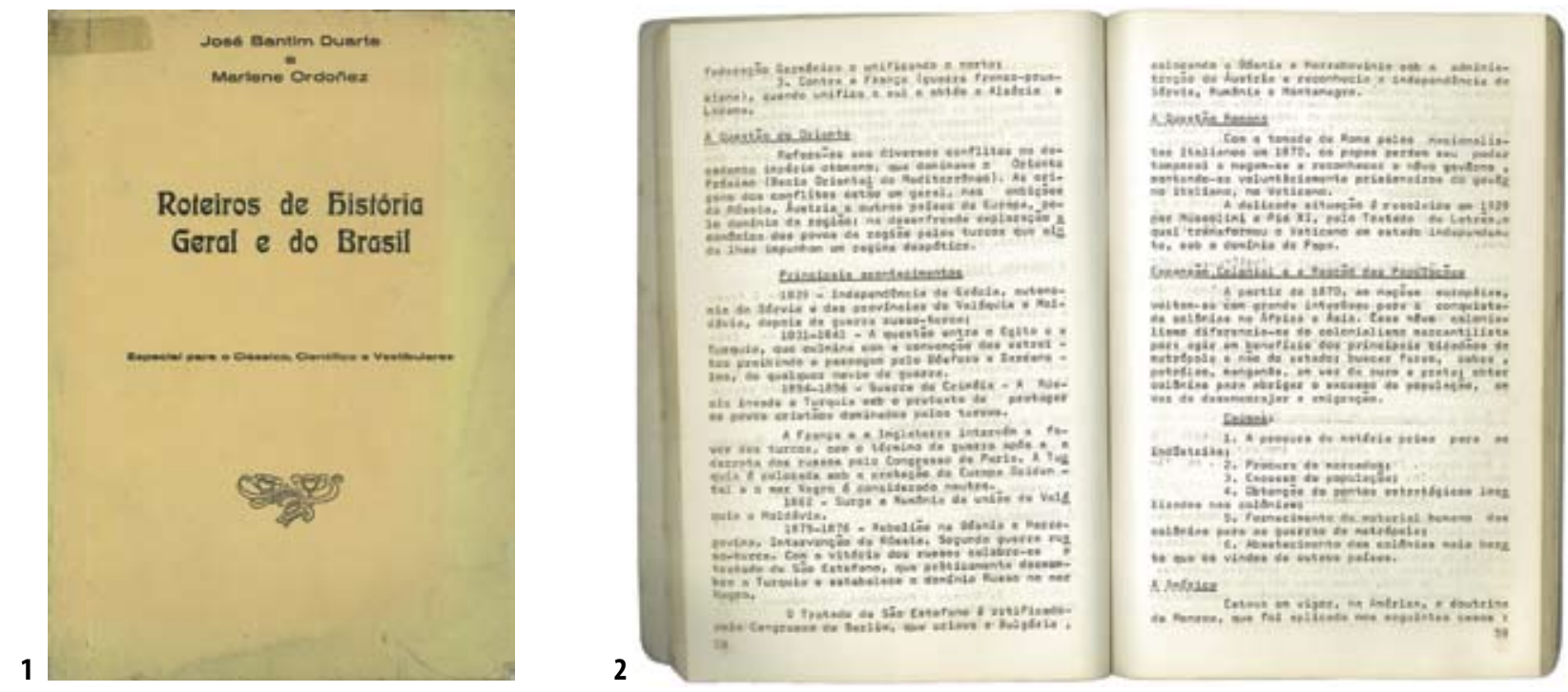

\section{Livros dos primeiros tempos da Ática:}

1 Roteiros de História Geral e do Brasil. José Bantim Duarte e Marlene Ordoñez. 1965. $(23,0 \times 16,0 \mathrm{~cm})$

2 Miolo da mesma obra, offset de matriz datilografada. conteúdo, derivava da experiência com materiais para uso em sala de aula e para estudo individual propiciada pelo curso de madureza (PAIXÃO, 1995, p. 211-213). A comunicação mais direta e informal com o aluno se materializava também numa relação entre texto e imagem e na presença de jogos, história em quadrinhos, até então inexistentes nos livros didáticos de tipo compêndio que dominavam o mercado. A transposição dessas outras mídias para o livro escolar, bem como a linguagem menos formal e mais direta parecem corresponder às mudanças de comportamento ocorridas na sociedade brasileira e mundial naqueles anos, particularmente o reconhecimento da presença de uma juventude que demandava a produção de bens culturais específicos.

Outra característica desses livros era uma nova estrutura, na qual cabia uma seção de exercícios com espaço para preenchimento das respostas pelo aluno, que tornava os livros utilizáveis uma única vez, consumíveis, como se diz hoje. O professor também passava a receber um livro exclusivo, que se diferenciava do livro destinado ao aluno por conter orientação didática, sugestões de uso e as respostas dos exercícios no espaço destinado ao preenchimento pelo aluno.

O primeiro título de grande sucesso que incorporava essas novidades foi a obra Estudo dirigido de Português, de Reinaldo Mathias Ferreira, cujo volume de 5. ${ }^{\text {a }}$ série teve uma primeira edição, em 1970, de 400 mil exemplares, que subiu para 1 milhão no ano seguinte. As obras deste autor somaram até o final da década 18 milhões de exemplares vendidos. As características dessa obra foram estendidas a livros das demais matérias, que também desbancaram títulos tradicionais do mercado, com vendas igualmente expressivas (PAIXÃO, 1995, p. 216).

Esse conjunto de inovações, introduzidas ou aperfeiçoadas pela editora e seguidas pelas demais, configurou um novo modelo de livro didático, existente até hoje, certamente por corresponder às necessidades da expansão econômica ocorrida naqueles anos, à massificação do ensino que se seguiu à Lei de Diretrizes e Bases de 1961 e à obrigatoriedade do ensino até a oitava série, estabelecida por lei em 1971. A expansão do magistério, não acompanhada das condições de trabalho necessárias - salários, carga horária compatível e formação adequada — prova- 

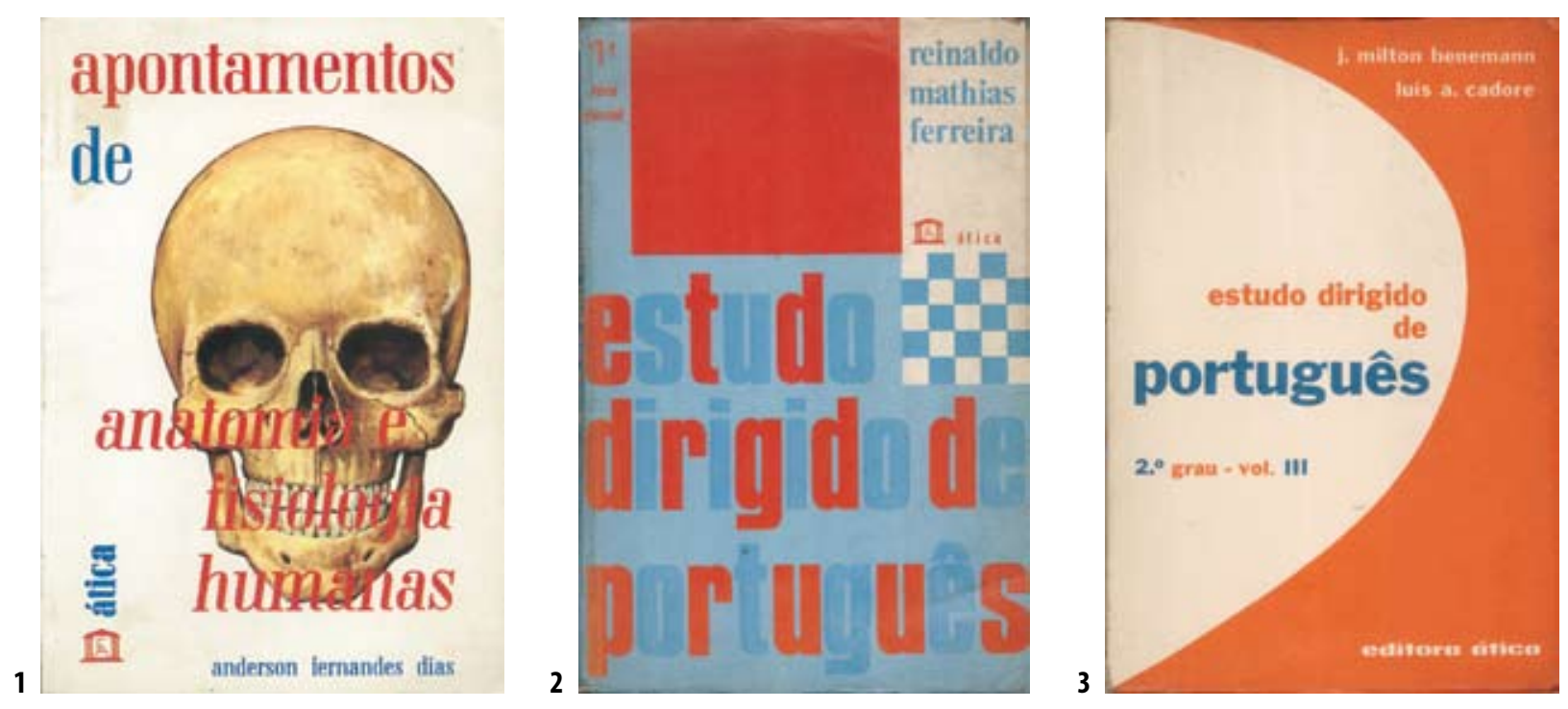

velmente tornou o livro do professor imprescindível e muitos mestres, dependentes dele.

Como já foi mencionado na Parte I, o contexto de expansão da rede pública e privada do ensino nos anos 1970 foi favorável ao aparecimento de novas editoras de didáticos, como a Moderna, a Atual e a Scipione, entre outras de alcance regional, cada uma delas surgindo para editar e comercializar o livro de seus proprietários-autores, afamados professores de cursos preparatórios ao vestibular, mas que rapidamente expandiram seus catálogos e dividiram o espaço com editoras tradicionais, como a Companhia Editora Nacional, a Saraiva, a Editora do Brasil e a FTD, e outra nova, o IBEP, chegando à década de 1990, como as principais fornecedoras de um dos maiores programas de compra e distribuição de livros no mundo para a rede escolar pública, o PNLD - Programa Nacional do Livro Didático.

O que diferenciará a Editora Ática das demais editoras que surgiram no rastro do crescimento do número de vagas no ensino público e privado, e o que a tornará a maior editora do país será sua expansão para outras áreas da atividade editorial, com inovações também na publicação de livros infantis, juvenis, universitários e literatura brasileira e internacional. É preciso dizer que essas inovações tiveram como base o próprio capital intelectual e concepções políticas de seu núcleo dirigente, capaz de formar um corpo editorial respeitado nos meios intelectuais e em condições de atrair e comprometer importantes nomes na criação de projetos inovadores e de impacto cultural reconhecido até hoje. No entanto, essas realizações só foram possíveis no contexto de expansão da indústria cultural do Brasil daqueles anos, assim apontados por Borelli (1995, p. 104):

Num balanço final é possível concluir que a Ática destaca-se, inicialmente, por penetrar de forma diferenciada no mercado de livros didáticos, em constituição desde o final do XIX, em expansão desde os anos 1930, e na mais completa consolidação a partir da década de 1960. Sua proposta é particular no sentido de ter definido um padrão de produção, divulgação e distribuição editorial perfeitamente adequado ao modelo de outras empresas culturais que, quando criadas, se expandem e consolidam-se na passagem dos anos 1960 para os 1970. A Rede Globo e a Embratel, por exemplo, geram respectivamente um padrão de televisão e de telecomunicações no Brasil. São todos frutos de uma

\section{Capas dos primeiros tempos da Ática:}

1 Apontamentos em anatomia e fisiologia. Anderson Fernandes Dias. 1969. $(23,0 \times 15,5$ $\mathrm{cm}$ )

2 Estudo dirigido de Português, 1. a série. Reynaldo Mathias Ferreira. 1971.

Capa Israel Socudo. $(20,7 \times 13,7 \mathrm{~cm})$

3 Estudo dirigido de Português, 2. ${ }^{\circ}$ grau, volume III. Milton Beneman e Luis Cadore. 1973. $(20,7 \times 13,7 \mathrm{~cm})$ 

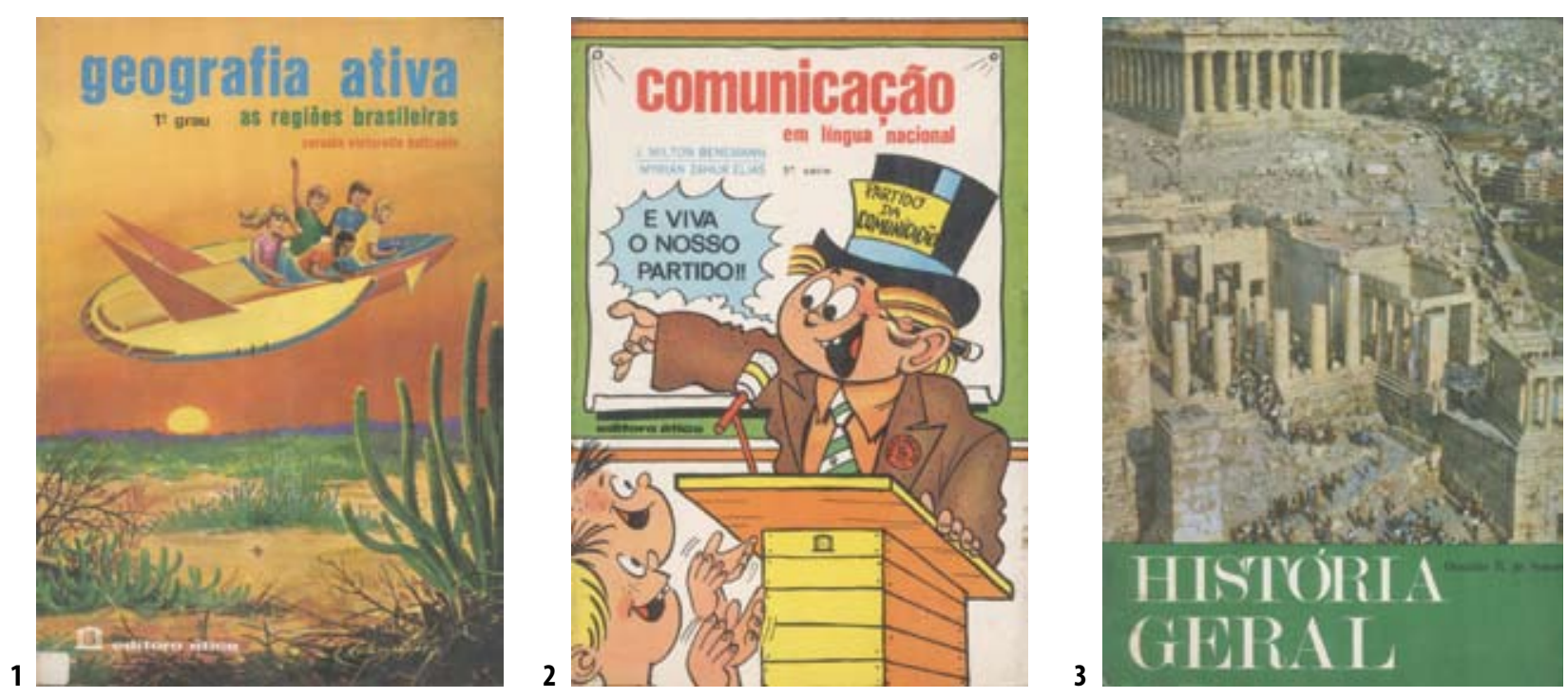

\section{Capas dos primeiros tempos da Ática:}

1 Geografia ativa. 1.० grau, 5. ${ }^{a}$ série. Zoraide Victorello Beltrame. 1972. Capa Eugenio Colonnese. $(21,5 \times 15,0$ $\mathrm{cm})$

2 Comunicação em língua nacional, 5. ${ }^{a}$ série. Milton Benemann e Myrian Elias. 1973. Capa Eduardo Pereira. $(20,4 \times 13,7 \mathrm{~cm})$

\section{História geral. Osvaldo} de Souza. 1973.

$(21,0 \times 14,5 \mathrm{~cm})$ mesma política econômica que inventa, também, o milagre brasileiro e imprime novo rumo nas relações entre capital nacional e estrangeiro. O mesmo procedimento ocorre em diferentes campos e atividades culturais, como cinema, música, publicidade e propaganda, artes e espetáculos em geral. O modelo proposto é perfeitamente compatível ao mercado de bens simbólicos emergente, no mesmo período, e praticamente inexistente no Brasil das décadas anteriores (Ortiz, 1988, pp. 113-148). A nova relação entre produção e mercado propicia o aumento considerável de empresas culturais e a diversificação evidente dos produtos oferecidos.

Hollanda \& Gonçalves (2005) referem-se também à modernização da produção cultural brasileira:

De fato, ao expressar uma nova composição de forças internas e um novo tipo de articulação do capitalismo brasileiro com o mercado mundial, o regime pós-64 irá trazer para o processo cultural uma série de implicações. A busca de integração com a produção industrial moderna, a transferência de capitais externos, a importação de novas técnicas e esquemas de organização produtiva vão exigir um reaparelhamento da produção cultural. Novas exigências de mercado, novas exigências técnicas. (cit., p. 98)

[...] As comunicações são modernizadas e a indústria cultural se desenvolve no sentido de mercado da classe média. Proliferam as enciclopédias em fascículos, tipo Abril, e congêneres, as coleções as mais variadas, do mundo animal à filosofia grega, da Bíblia às revistas especializadas. A música popular assiste à emergência de marchinhas exortativas e o sambão joia faz fundo musical para as novas churrascarias. As artes plásticas tornam-se rentável negócio, concorrendo com a bolsa de valores, no teatro as grandes produções empresariais dominam a cena aberta, e o cinema começa a colocar-se a necessidade de assumir, definitivamente, sua maturidade industrial. (cit., p. 100)

Na área que nos diz respeito, Borelli é bastante precisa ao afirmar que"o projeto editorial da Ática colabora na configuração da história cultural e editorial deste período", e seu sucesso se deve por responder "oportunamente, aos sinais enviados pela realidade de mercado em transformação":

As decisões que fazem dela uma editora diferente resultam de um conjunto de realizações: imprimir nova concepção na utilização do livro didático, com a criação do livro do professor e do livro do aluno; realizar as coleções paradidáticas e universitárias; armar projeto que articula a edição de livros tendo como referência o sistema educacional pensado como totalidade, do $1 .^{\circ}$ ao $3 .^{\circ}$ graus; e, por fim, destinar, prioritariamente, a produ- 

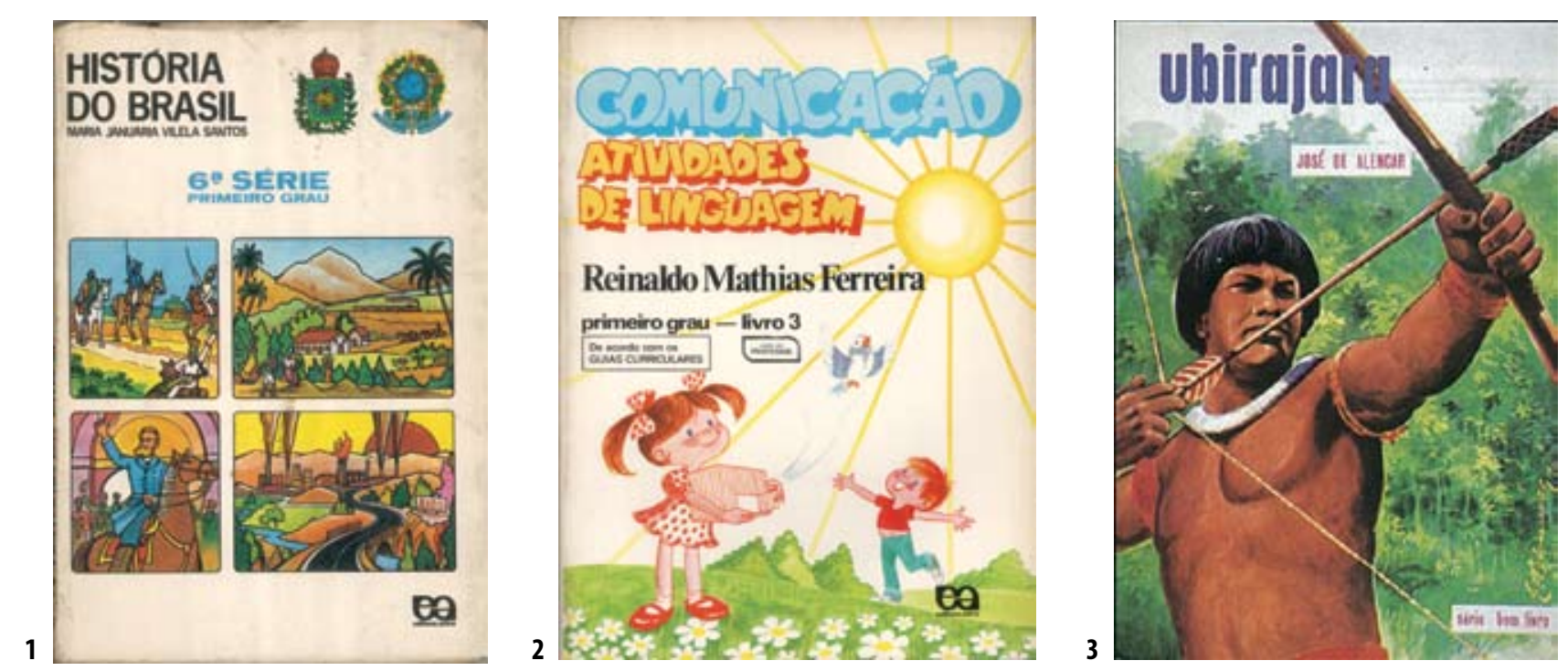

ção editorial aos novos personagens que irrompem no cenário brasileiro: estudantes de 1. ${ }^{\circ}$ e 2..$^{\circ}$ graus e de faculdades que proliferam aos borbotões a partir dos anos 1970 no Brasil. (BORELLI, 1995, p. 104)

Rede Globo e Editora Abril são mencionadas como exemplos de empresas culturais que viveram intensa profissionalização na elaboração e distribuição de seus produtos e criaram padrões de consumo que não poderiam ser ignorados por quem mais se propusesse a atingir o amplo público a que elas se dirigiam.

Assim, o interesse em expandir a produção para outros segmentos editoriais além dos livros escolares obrigou a editora Ática a buscar trabalhadores intelectuais no mercado editorial mais profissionalizado que havia. A referência à Editora Abril fica ainda mais justificada, pois, além de padrões gráficos e editoriais que suas revistas e publicações veiculavam e tornavam modelos de gosto para o público, foi de suas redações que saíram muitos dos profissionais que ocupariam as editorias especializadas tanto na área de didáticos como nas de interesse geral que a Ática criou. $^{3}$

A primeira coleção da editora que representa essa expansão para além das obras didáticas é a série Bom Livro, de clássicos da literatura brasileira e portuguesa, lançada em 1970 e dirigida por Jiro Takahashi. Além do texto integral, cotejado cuidadosamente com edições confiáveis, os volumes traziam notas explicativas e um encarte, a ficha de leitura, com roteiro e questões para o estudante se exercitar na compreensão do texto. O preço reduzido, devido às altas tiragens e uso de papel mais barato, garantiu o sucesso nas escolas. O apelo da capa, em quatro cores e ilustração sangrada feita por Eugenio Colonnese, quadrinista italiano radicado no Brasil, certamente contribuiu para a popularização da coleção, marcando a preocupação da editora com esse aspecto, ainda se inspirasse na linguagem das capas da coleção Saraiva e da Terramarear, da Companhia Editora Nacional, de grande sucesso nas décadas de 1930 a 1950.

Os outros lançamentos que caracterizarão o estilo editorial da Ática e o cuidado com o tratamento gráfico serão abordados na próxima seção. Por ora, é importante ressaltar que foi essa procura de inserção na produção livreira geral do país o

Capas dos primeiros tempos da Ática:

1 História do Brasil. 1. ${ }^{\circ}$ grau, 6. ${ }^{a}$ série. Maria Januária Vilela. 1974. Capa J. Rigoletto. $(21,7 \times 14,7 \mathrm{~cm})$

2 Comunicação: Atividades de linguagem, 1. ${ }^{\circ}$ grau, livro 3.

Reynaldo Mathias. s/d. $(27,5 \times 20,2 \mathrm{~cm})$

3 Ubirajara. Série Bom Livro. Capa Eugenio Colonnese. 1970 ?

3 Sobre a trajetória dos profissionais da área editorial da Ática e outras editoras, ver MUNAKATA, 1997. p.121-127. 
que levou a editora a se comprometer com a necessidade de linguagens gráficas mais contemporâneas e "universais".

Foi nesse contexto que se deu a iniciativa de promover um concurso para a criação de um novo logotipo para a editora, em 1974, e a experiência inicial com seu vencedor, Ary Normanha, à frente de alguns projetos gráficos na condição de prestador de serviço autônomo (PAIXÃO, 1995, p. 229), além da participação de outros designers e ilustradores atuantes nos principais veículos de comunicação impressa da época, como Elifas Andreatto e Mário Cafiero.

Já os livros didáticos - com produção editorial e de arte mais complexa, e com público praticamente cativo determinado pela importância do autor e sem outras referências visuais no mercado a não ser a produção convencional e. num certo sentido, precária como vimos na Parte I - esperarão um pouco mais para sofrer uma transformação visual mais radical. Será só após a configuração visual das obras do segmento não-didático e paradidático que essa preocupação será passada para os didáticos, com a contratação de Ary Normanha para a execução das capas e de alguns projetos gráficos de miolo dos livros e, em seguida, de Mário Cafiero. 


\section{OS DESIGNERS E SUAS REFERÊNCIAS}

A renovação que a editora Ática vai promover nas capas dos livros didáticos se apoiou na experiência de profissionais trazidos de outras áreas da comunicação visual que não a editorial de livros didáticos. Esta é a diferença fundamental em relação a parte significativa das demais editoras, que tinham suas equipes geralmente formadas dentro da própria cultura editorial escolar e com pequeno grau de profissionalização em linguagem visual e gráfica. A trajetória e experiência anterior desses profissionais - mesmo que não tenham tido educação formal em arte e design - e as linguagens com que trabalhavam foram determinantes para a visualidade diferenciada que a editora Ática imprimirá a seus livros.

\subsection{Ary Normanha e o design de revistas}

Ary Almeida Normanha nasceu em 1948, em São João da Boa Vista, de onde se mudou, aos cinco anos, para Ribeirão Preto. Desenhava desde pequeno, lia muito e como estudante participou ativamente da vida política do país. Aos 14 anos, já militava no Partido Comunista e, com 18, aderiu à Ação Libertadora Nacional, dissidência do PCB, deixando de seguir o curso de Engenharia, para o qual fora aprovado no vestibular. Mudou-se para São Paulo, onde se engajou no "tático armado" da ALN, e foi preso duas vezes, sem acusação que sustentasse uma condenação, pois não chegara a participar de nenhuma ação.

Esses fatos biográficos servem para mostrar como, segundo suas próprias palavras (NORMANHA, 2008), seu ingresso na área de artes gráficas foi quase casual. Após sua segunda prisão, decidiu abandonar a militância política devido à grande infiltração existente nas organizações de esquerda, mas não tinha uma profissão para se manter. A partir dos conhecimentos que travou na militância e na prisão, foi encaminhado para a área do jornalismo, onde viu que poderia empregar sua habilidade com o desenho associada ao hábito de leitura que cultivava desde a infância. Assim, o amigo Fernando Morgado, jornalista da Folha de S. Paulo, apresentou-o aos responsáveis da Arte \& Comunicação, empresa que reuniu a equipe da revista Realidade demitida da Editora Abril após a edição do Al-5, em 1968 (NORMANHA, cit.).

A Arte \& Comunicação editava Bondinho, Grilo, Jornalivro, Palavrão e Revista de Fotografia, publicações inovadoras tanto na forma dos textos como na linguagem gráfica, cuja ousadia derivava da experiência da grande revista de reportagens que foi Realidade (cf. HOMEM DE MELO, 2006, p. 147-149) e da vontade de seus profissionais de intervir na vida política e cultural em oposição à ditadura (cf. KUCINSKI, 2003, p. 231-234). Como assistente de arte, Ary teve a oportunidade de conviver e aprender a diagramar e ilustrar com renomados profissionais, os jornalistas Narciso Kalili e Sérgio de Sousa, e os artistas gráficos - como na época se denominavam estes profissionais - Eduardo Barreto Filho, Paulo Lafer de Jesus (Polé) e Rudi Alves, que Ihe atribuíam responsabilidades.

Segundo depoimento de Eduardo Barreto e Polé para Chico Homem de Melo 

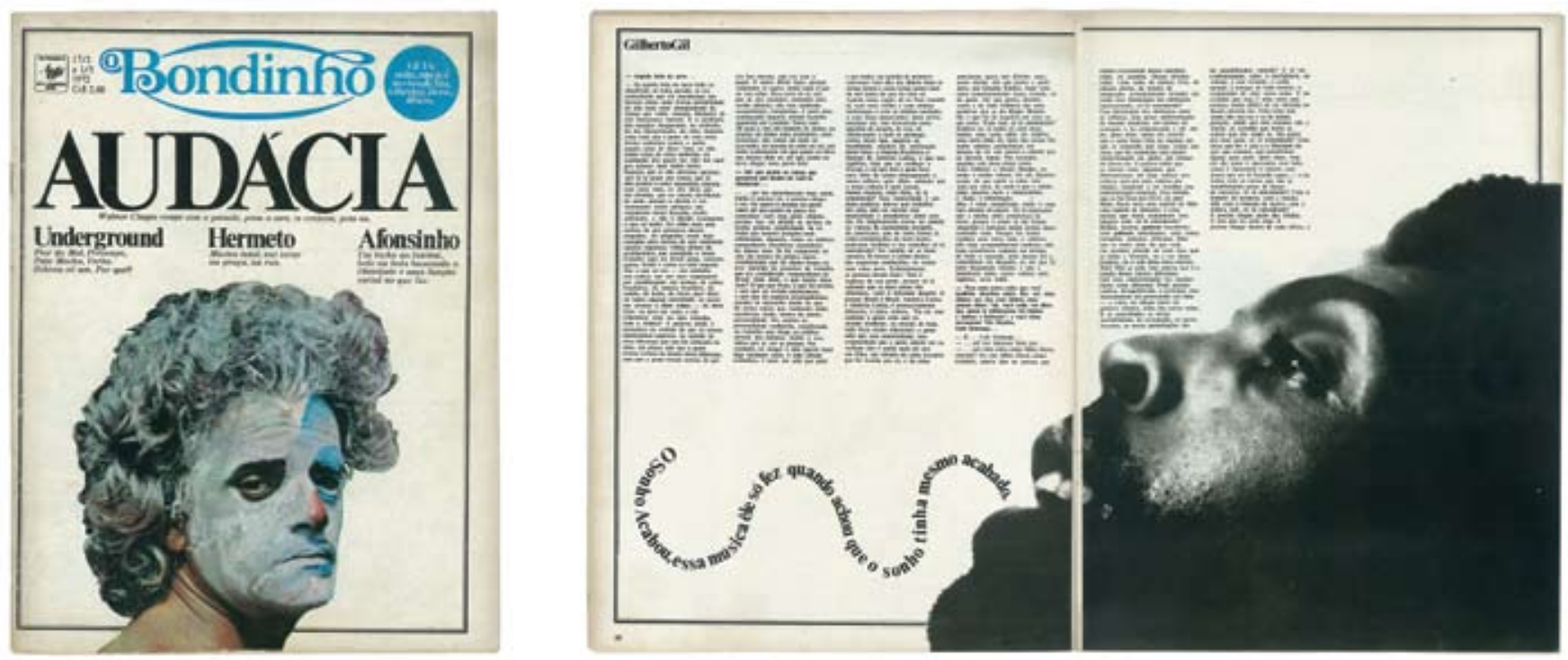

Bondinho. Edição de 17/2 a $1 / 3$ de 1972. Capa e páginas internas.
(2006: p. 183-184), esses profissionais tinham dentro da Abril total acesso à informação gráfica internacional, através de revistas e anuários de design bem como de revistas para públicos mais amplos. Eduardo Barreto estagiou em importantes revistas norte-americanas e o próprio projeto gráfico de Realidade foi influenciado pela alemã Twen.

Assim, além de referências já consideradas clássicas no design editorial como as revistas Harper's Bazaar e Esquire, e do trabalho dos chamados pioneiros da Escola de Nova York - Paul Rand, Alvin Lustig, Bradbury Thompson e Saul Bass - , esses profissionais conheciam o que era mais novo no design gráfico internacional: a produção tipográfica/editorial de Herb Lubalin, o design-ilustração do Push Pin Studio (Milton Glaser, Saymour Chwast etc.), a cartazística polonesa e o design underground que despontava no movimento de contracultura surgido na Califórnia.

O design de Bondinho, por exemplo, em sua primeira fase como revista-guia de serviços produzida para os clientes da rede de supermercados Pão de Açúcar, foi bastante influenciado pelo design-ilustração do Push Pin Studio. Na segunda fase, já como publicação independente vinculada à chamada contracultura, incorporou também o tratamento gráfico e a iconografia das publicações underground.

Essa informação, é importante tanto para compreender a origem do "estilo" de design das publicações da Arte \& Comunicação como do próprio design de Ary Normanha, pois, da mesma forma que seus mestres, adquiriu sua formação na prática da edição de arte "a quente" nas revistas e não na universidade.

A prática desse design editorial nas revistas brasileiras de certa forma reproduz o que ocorreu no surgimento do design editorial norte-americano, além de se referenciar na visualidade que este design criou. Para Hollis, "Foram os diretores de arte, nos anos 30, que instituíram o design gráfico, especialmente na publicidade e no layout das revistas" (2005, p. 118).

Mas, além do trabalho como assistente de arte, Normanha fazia a secretaria gráfica das publicações da Arte \& Comunicação, o que lhe deu a oportunidade de conhecer as principais gráficas de São Paulo e do Rio de Janeiro e de acompanhar todas as etapas de produção, num aprendizado intenso e profundo dos processos 


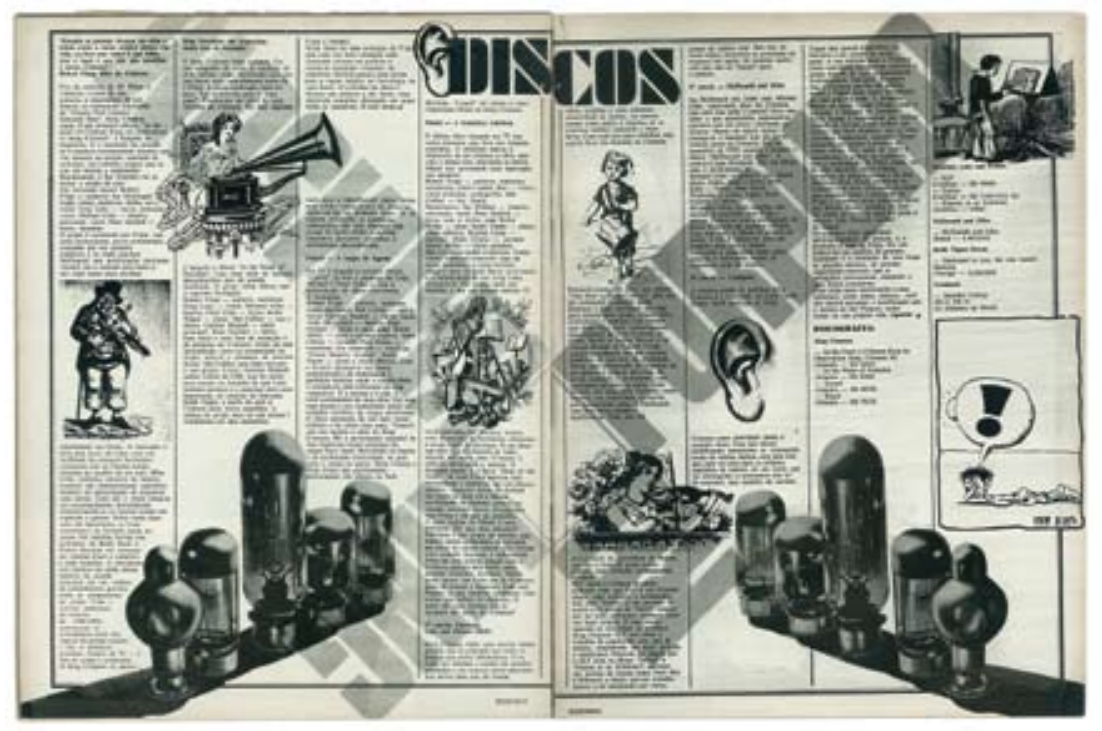

de pré-impressão (fotolito), impressão (offset e rotogravura) e acabamentos, decisivos para o desenvolvimento dos projetos complexos que realizará na Ática.

Sobre o seu aprendizado estético, considera que a base foi mesmo a prática do desenho, pois, "quando você começa a desenhar ainda em criança, já tem uma preocupação em relação a composição; isso tudo traz a você uma certa ordem, em relação ao conceito, ao pensamento de como resolver uma coisa, de como realizar, tanto em questão de conteúdo, como em questão da forma" (NORMANHA, cit.). A seu ver, com o tempo e a prática vem o desenvolvimento, mas no seu caso afirma que o que mais contribuiu foi o volume e a diversidade de trabalho. Como exemplo, cita a Revista de Fotografia da Arte \& Comunicação, editada por George Love — fotógrafo norte-americano que se mudou para o Brasil e trabalhou em Quatro Rodas, Cláudia e Realidade - , experiência a que Normanha atribui muito do apuro visual que adquiriu, pois "o trabalho com essa revista requeria muito requinte, muito cuidado para não estragar o trabalho do fotógrafo". Como exigência desse trabalho, foi fazer o curso de fotografia na Foco, escola ligada aos fotógrafos da Realidade, como a suíça Claudia Andujar, a inglesa Maureen Bisilliat, Pedro Martinelli e outros, "profissionais que estimulavam a participação, o que favorecia a transmissão dos conhecimentos" (NORMANHA, cit.).

A Arte \& Comunicação foi, assim, a sua grande escola, pois "era um ponto de encontro de profissionais com uma bagagem muito grande, tanto na parte de texto como de arte", propiciando a experiência que considerava fundamental, a de todo mundo trabalhar junto, num mesmo espaço, em que tudo era discutido e em que o diagramador participava intensamente, lendo integralmente o texto a que daria forma, solicitando aos autores do texto alterações que permitissem criar destaques visuais que resultassem em páginas mais atraentes e que favorecessem a leitura e comunicação do conteúdo textual (NORMANHA, 2008). Após o fechamento da empresa, apesar do sucesso de suas publicações, essa experiência pôde continuar com a Espaço \& Tempo, que publicou o Ex, dirigido por Hamilton de Almeida Filho, o Haf, originário de Realidade e de Veja ${ }^{7}$. Em seguida, Ary Normanha venceu o concurso promovido pela Editora Ática e recebeu o convite para lá trabalhar.
Bondinho. Edição de 11 a $25 / 5$ de 1972 . Capa e páginas internas.
7 Sobre as razões que levaram à falência das duas empresas e a história de suas publicações, bem como de toda a chamada imprensa alternativa e"nanica", ver KUCINSKI, cit. 

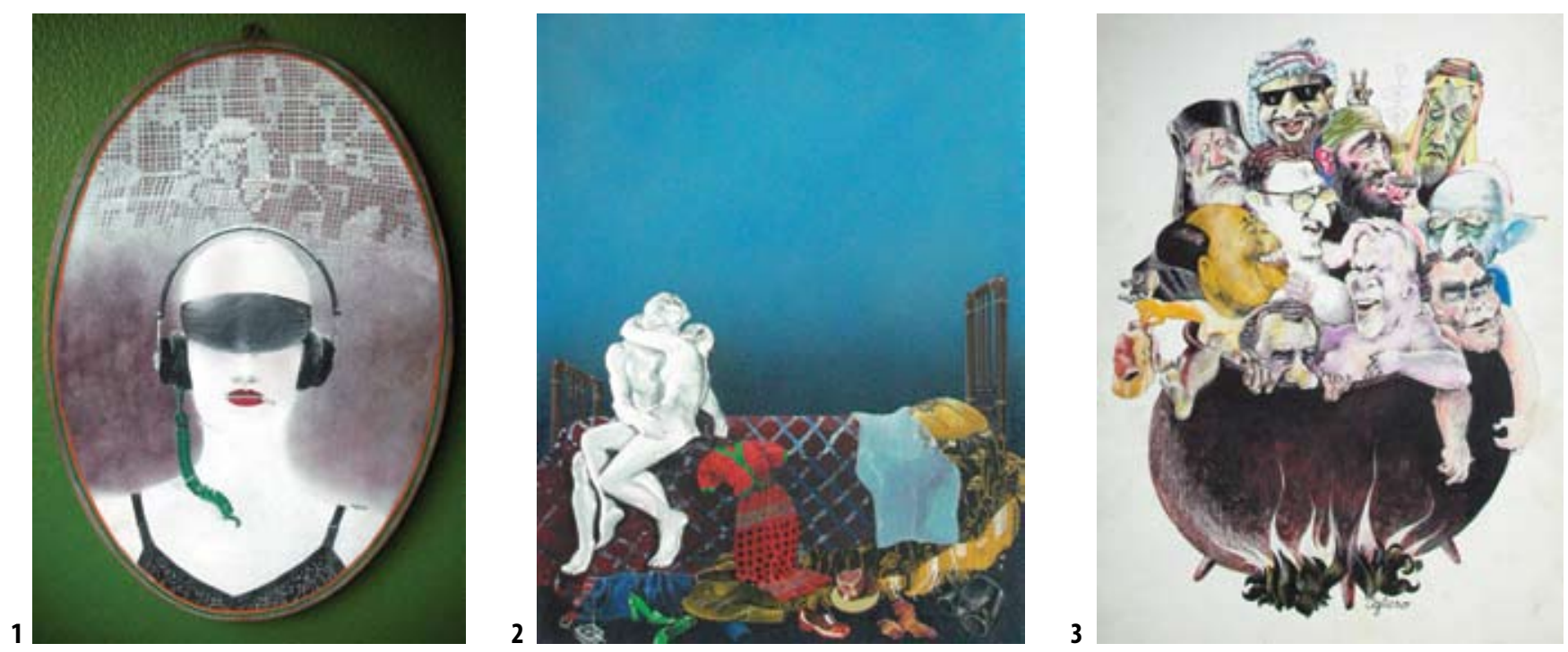

1 Revista Cláudia. 1970 llustração.

2 Revista Nova. 1970. llustração.

3 Revista Visión. n.d. Charge.

\subsection{A experiência de Mário Cafiero: a ilustração e edição de revistas}

Se Ary Normanha dirigiu o processo de renovação da linguagem de capas dos livros didáticos da Ática, contou com a colaboração do designer e ilustrador Mário Cafiero nos principais projetos desde os trabalhos com livros não didáticos.

Filho de operário gráfico e com habilidade para o desenho, por volta de 1964 e com treze anos de idade, Mário Sílvio Cafiero foi apresentado pelo pai aos responsáveis pelo departamento de publicidade da RCA Victor de São Paulo, onde estagiou para Mário Tabarin e José Anezzi, que também produziram os primeiros fascículos da Escola Panamericana de Arte. Indicado por eles, no ano seguinte foi trabalhar na editora Prelúdio, que publicava a revista Melodias, de letras e cifras de canções, fotonovelas e histórias em quadrinhos nacionais. Com isso, aprendeu a diagramar, ilustrar, letrar balões e ajudar na produção e iluminação de fotografia, conhecendo os processos mais tradicionais, como a linotipia e o clichê, a bicromia e a tricromia, aplicados em produtos de baixa qualidade cultural e num ambiente intelectualmente precário (CAFIERO, 2009).

Como alguns dos prestadores de serviço da Prelúdio também trabalhavam para outras empresas, foi levado por Caetano Guerardi e Wladimir Araújo para trabalhar na Editora Abril. Com isso, em 1969, com 17 anos de idade, já diagramava e ilustrava a revista Cláudia, sob a direção de arte de Atílio Basquera. Lá desenvolveu um traço para a ilustração de matérias para o público feminino, que também aplicou na revista Nova e na finalização de layouts que fazia "por fora", para os perfumes Rastro, e outros clientes. Também fazia "boca de máquina" (acompanhamento da impressão) e participava da prismagem das ilustrações (dimensionamento das imagens para aplicação nas páginas), o que lhe deu um conhecimento do processo total de edição de revistas, completando "a transição do clichê para o fotolito".

Já considerando que tinha experiência e conhecimento suficiente para exercer funções superiores à de assistente de arte, com o grande sucesso dos fascículos da Abril Cultural, reivindicou uma promoção e foi trabalhar na Divisão de Educação, ligada aos fascículos. Aí encontrou um ambiente intelectualmente estimulan- 

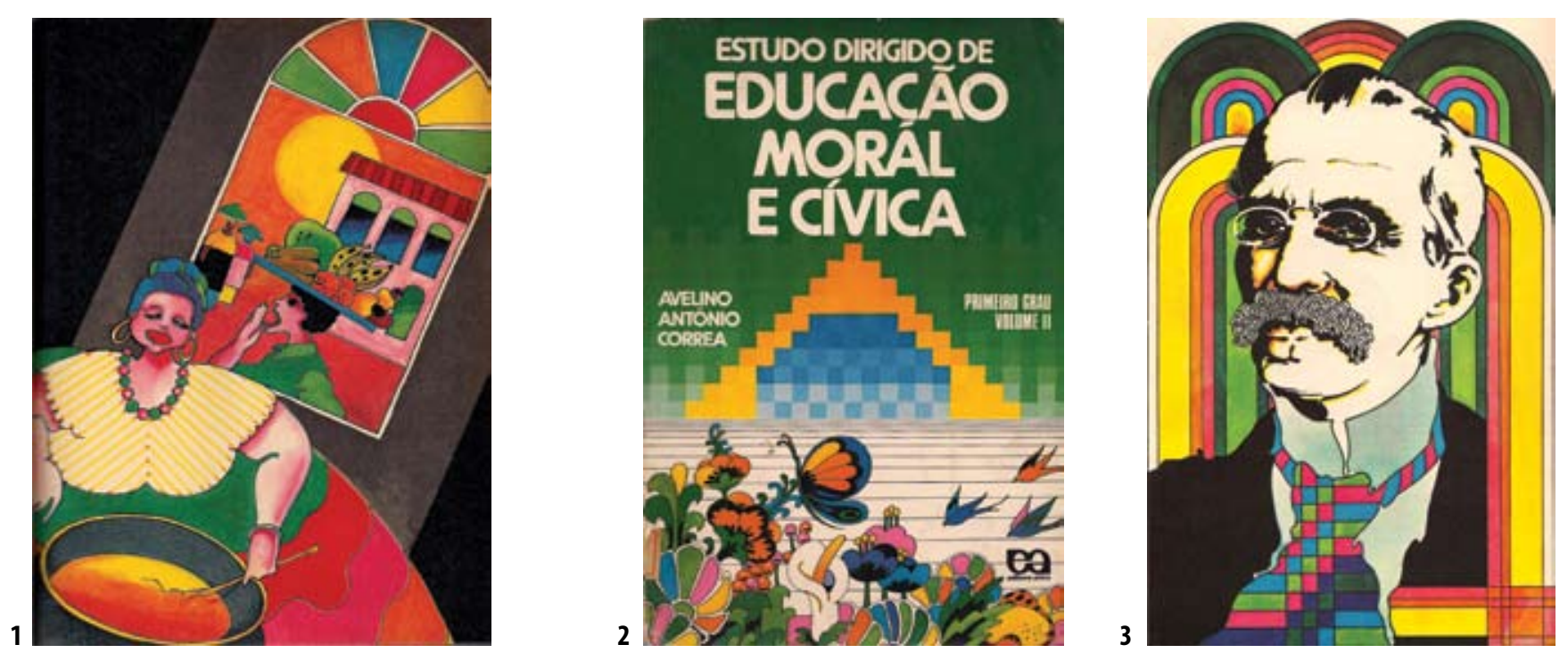

te, com grande intercâmbio entre a redação e a arte e na confeção de obras por que se interessou muito, e onde podia interpretar e ilustrar autores de literatura de que gostava, como ocorreu com o livro Tempo de Comunicação, de Ada Natal Rodrigues, que considera um marco "revolucionário" no livro didático brasileiro. Lá conviveu com os editores José Carlos Monteiro da Silva, Sônia Junqueira e Luiz Raul Machado, e com os artistas gráficos Luís Trimano e Elifas Andreato.

Para a Ática, a convite de Marino Lobello, fez em 1972, sob o pseudônimo de M. Mariano, capa e ilustrações de miolo da obra didática Educação Moral e Cívica, de Avelino Correa, um original "conservador" a que deu um tratamento inusitado.

No entanto, mesmo tendo recebido prêmios por seu trabalho pessoal, como o de aquisição pelo MAM do Rio de Janeiro, acreditava que o fato de não ter estudado além do colegial criava obstáculos para sua valorização profissional, além de ressentir-se de pouca informação sobre história da arte e as linguagens contemporâneas. Com os recursos acumulados por trabalho intenso, conseguiu em 1973 viajar para Londres e passar seis meses apenas visitando museus e tendo contato com a cultura visual produzida naqueles anos, a que atribui importância decisiva para sua formação artística e profissional. Por fim, com seu portfolio brasileiro, foi selecionado para o cargo de subdiretor de arte das revistas do grupo Visión, editadas em Londres mas dirigidas a diversos países da América Latina, assumindo em seguida a direção. Lá, além de executar charges políticas, "aprendeu a combinar ilustração e tipografia". Após dois anos em Londres, morou e trabalhou seis meses em Paris, antes de retornar para o Brasil, em 1976.

Aqui teve a oportunidade de realizar mais um trabalho importante para a Ática, antes de receber o convite para trabalhar na editora, o projeto gráfico e a ilustração do infantil João Teimoso, que lhe valeu a coautoria com Luiz Raul Machado. Acredita que as duas experiências para a Ática, mas principalmente o fato de ser um artista que dominava o desenho, correspondiam à abordagem que Ary Normanha pretendia dar ao design dos livros, a partir da experiência desse designer no Bondinho e à sua habilidade tipográfica, que um trabalho de ilustração poderia complementar.

1 llustração para Tempo de Comunicação. Ada Natal Rodrigues, Arlette Azevedo de Paula. Abril,1974.

2/3 Capa e ilustração para Estudo Dirigido de Educação Moral e Cívica, vol. 2. Avelino Correa. Ática, 1. ed. 1973. 
Sobre as influências que trouxe nessa época, diz que, além do grafismo psicodélico de Yellow Submarine e do design-ilustração do Push Pin, que conheceu por uma exposição no Masp no início da década de 1970, admirava o "tratamento do feminino" feito pelo artista gráfico brasileiro J. Carlos, que conheceu por um livro que ganhou de Luiz Raul Machado. Cafiero acredita que fez uma certa mistura dessas referências de países e épocas diferentes num trabalho de cunho pessoal pela interpretação e tradução para o visual que precisava fazer de textos brasileiros num contexto, num momento e a partir de uma vivência brasileira (CAFIERO, 2009).

\subsection{A Escola de Nova York e o design-ilustração}

Tanto no design do Bondinho como nas realizações de Cafiero, vê-se a influência exercida pelo design-ilustração criado pelos membros do Push Pin Studio, particularmente Milton Glaser e Saymour Chwast. A mencionada habilidade em combinar tipos que Cafiero admirava em Normanha tem também um precedente no trabalho de Herb Lubalin.

Embora essas duas referências não se confundam, pode-se dizer que têm uma origem e algumas características comuns. Lubalin prossegue a "abordagem original do design moderno" recebido da vanguarda europeia, em função de "especificidades da cultura e sociedade norte-americanas", feita pelos designers de Nova York (MEGGS, 2009, p. 484). A uma das abordagens desses designers, a tipografia figurativa, em que letras tornam-se objetos ou objetos tornam-se letras, Lubalin acrescenta o expressionismo tipográfico, em que letras traduzem conceitos ou mesmo estados mentais, explorando a liberdade de manipulação propiciada pela nova tecnologia da fotocomposição.

Num impulso mais radical de negação à chamada "frieza" da tipografia e do design funcionalista europeu, já num contexto de presença da Pop Art e tendo com ela o mesmo substrato, o Push Pin funde tipografia e ilustração num único design, que recupera a ilustração e a tipografia da arte comercial e do repertório vernacular norteamericanos, num viés de humor e ironia, mas também a iconografia vitoriana, art nouveau e art déco, igualmente recusadas pelo modernismo. Exatamente porque os Estados Unidos tinham uma grande tradição de arte comercial, decorrência da pujança de sua indústria e do elevado consumo de massas, é na tipografia e na ilustração dessa arte comercial que vários designers nas décadas de 1950 e 1960 vão buscar referências para criar um design menos sério e mais envolvente, mas que não deixava de incorporar as conquistas e procedimentos dos designers norte-americanos influenciados pelo modernismo (HELLER, 2007, p. 116-118).

Um design que se apoia na tradição imagética vernacular e anônima e incorpora o ornamento e a ilustração é um reconhecimento da validade do imaginário e do desejo populares para a construção da forma e de seu significado e comunicação. Nesse sentido, a imaginação e o humor presentes nesse design distancia-se do que apresentava o design funcionalista estrito, que em geral não considerava como função do design a fantasia ou a sugestão de outras imagens, mas apenas o uso estrito e a comunicação objetiva. Daí talvez o poder de atração e influência desse novo design sobre designers do mundo inteiro. 

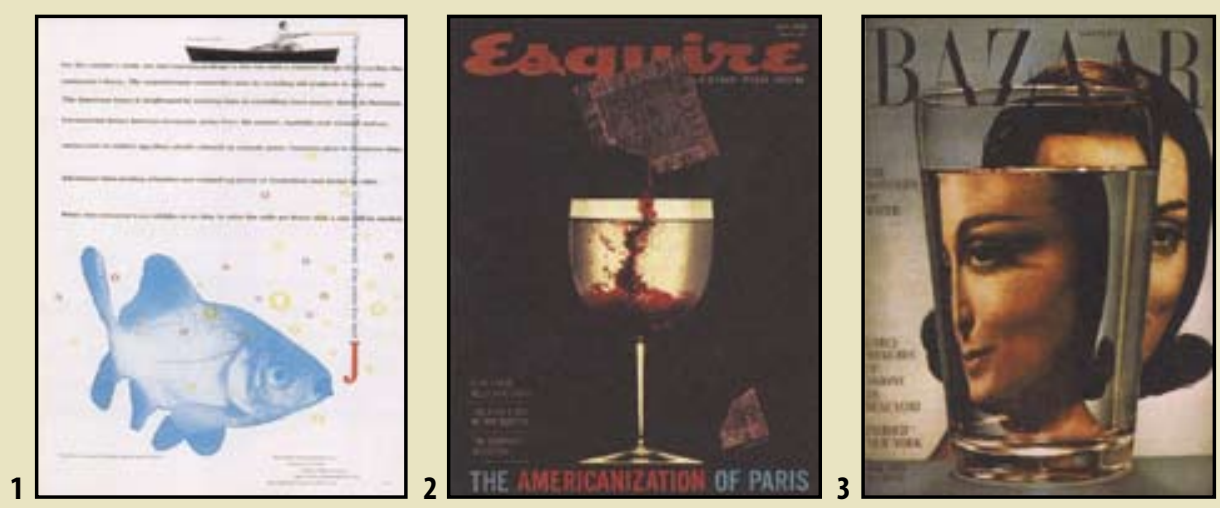

1 Bradbury Thompson, 1949. 2 e 3 Henry Wolf, 1958 e 1959.
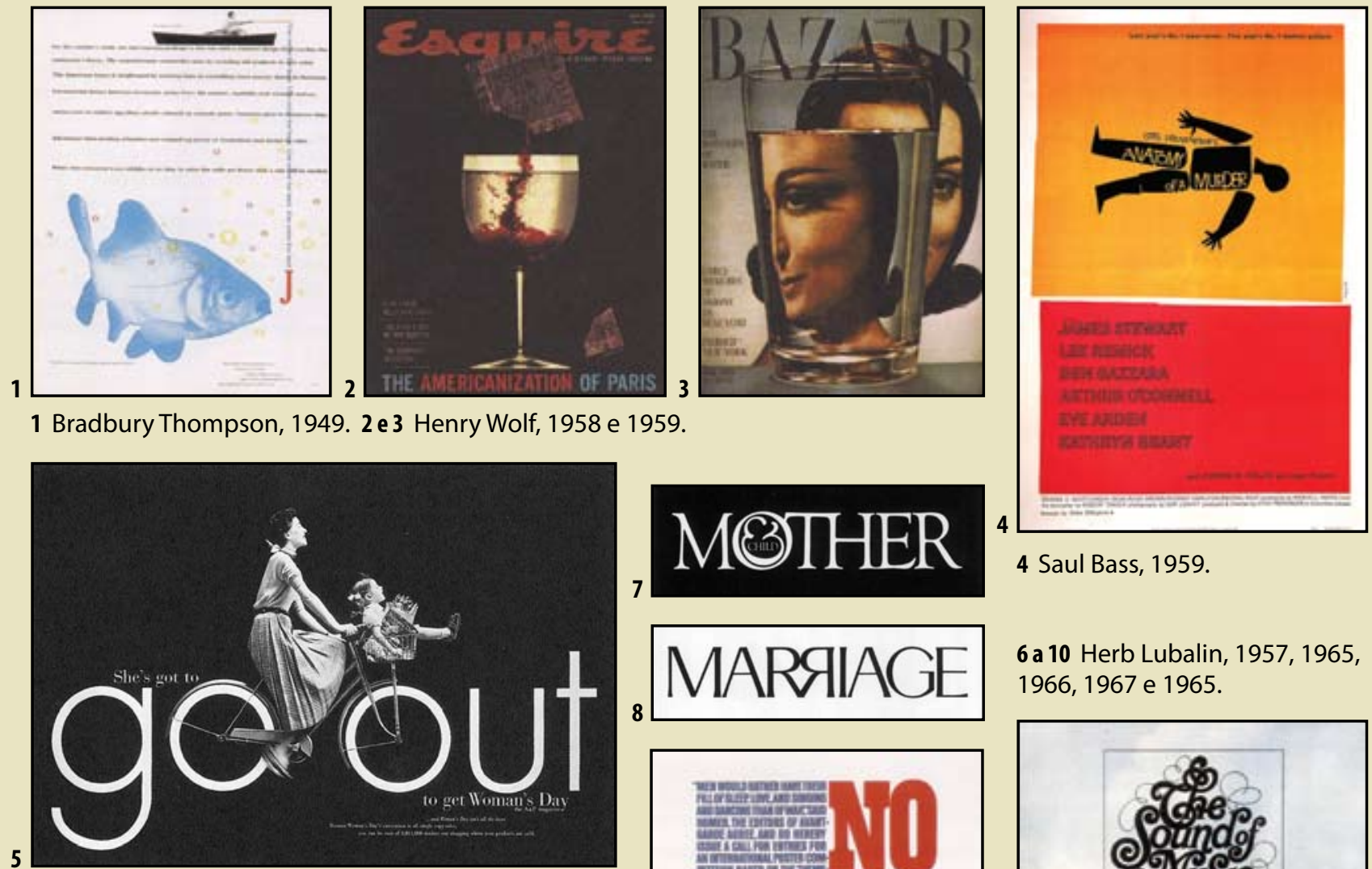

5 Gene Federico, 1953.
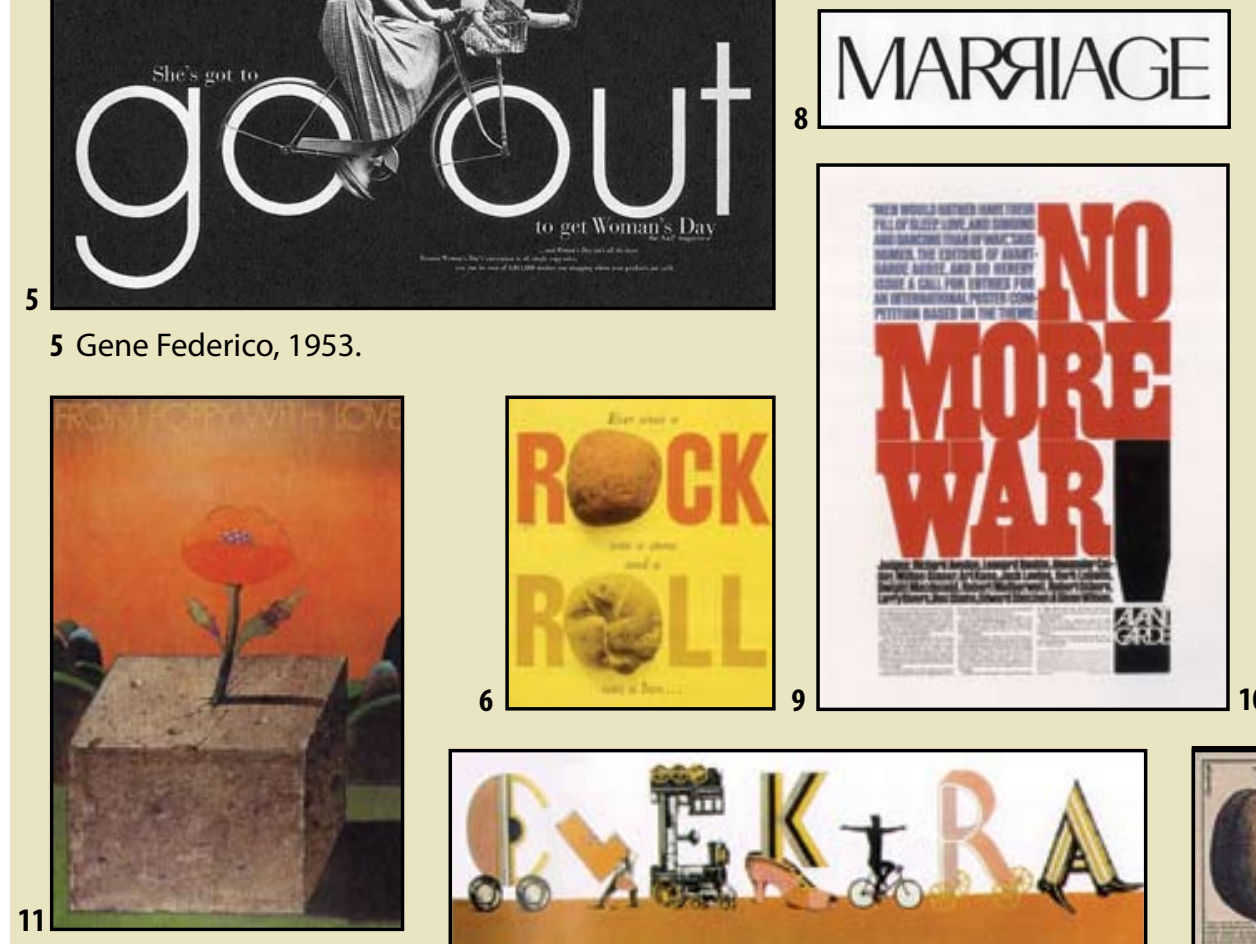

6 a 10 Herb Lubalin, 1957, 1965, 1966, 1967 e 1965.
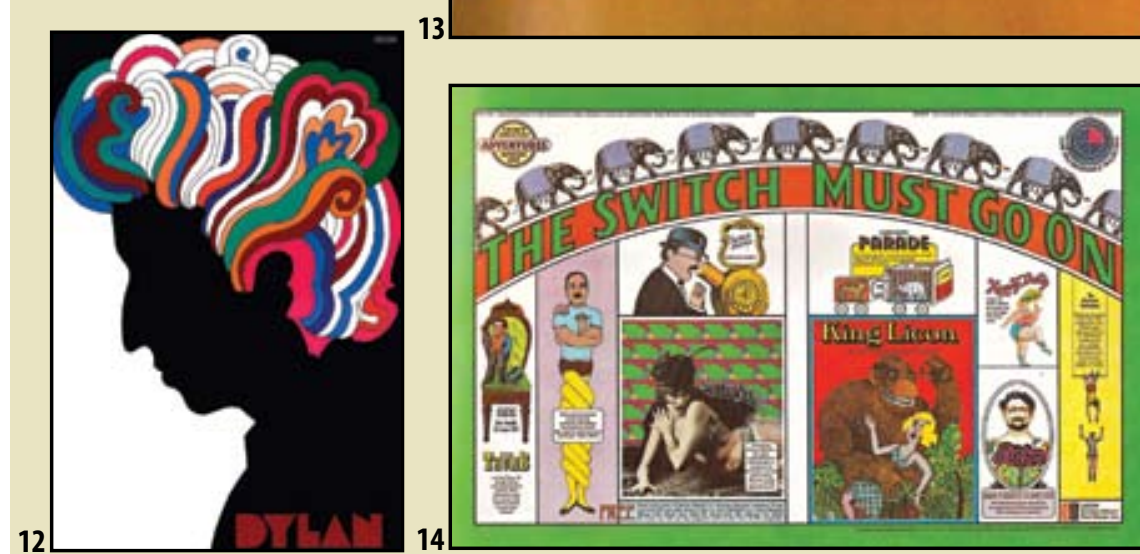

Push Pin: 11/12 Milton Glaser, 1967, 1968. 13/14 Saymour Chwast,1965, n.d.
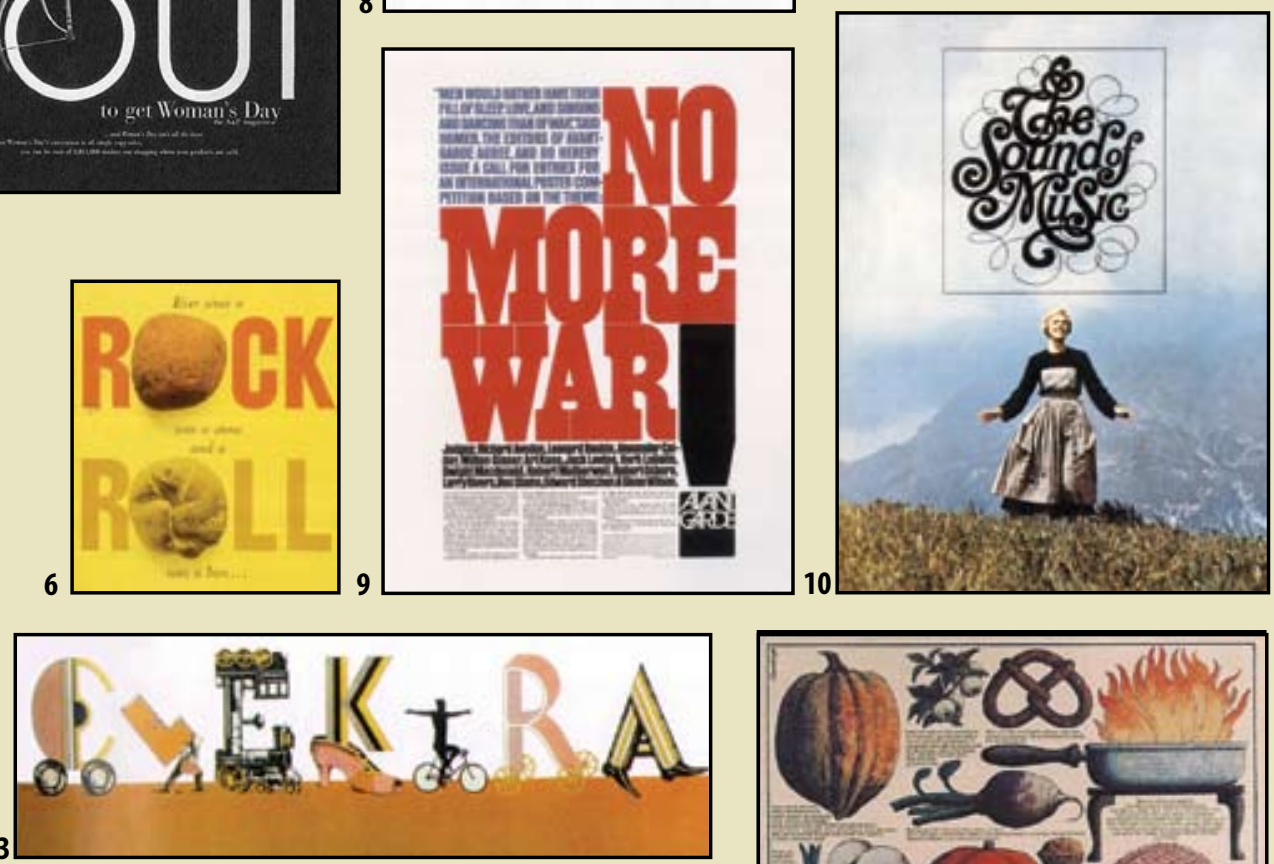

Exemplos do design da Escola de Nova York e do design-ilustração

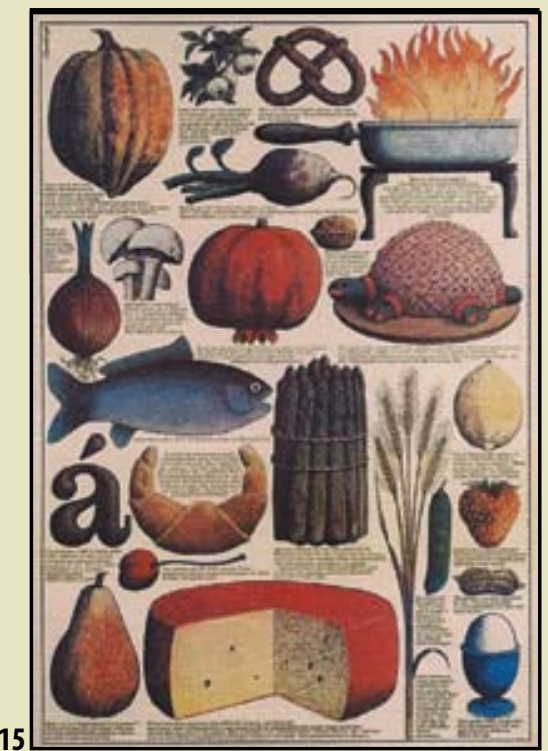

15 Arnold Varga, 1966. 


\section{OS PRIMEIROS PROJETOS}

Embora o foco deste trabalho seja a renovação da linguagem de capas de livros didáticos promovida por Ary Normanha para a Ática, com a participação inicial mas decisiva de Mário Cafiero, ela só pode ser explicada pela atuação desses designers na construção da visualidade da editora nos projetos que antecederam seu trabaIho com os titulos escolares.

E a atuação de Normanha se dá exatamente no momento em que a editora constrói seu "estilo" e projeto editorial, pois é dele a maioria dos projetos gráficos que materializarão as coleções lançadas pela editora e sua imagem de modernidade e intervenção na vida cultural e literária do país. Sua participação é decisiva na construção mesma do projeto editorial da Ática, e sua dedicação posterior também à área didática, com a extensão para ela de novas linguagens gráficas, é consequência natural do desenvolvimento e profissionalização da empresa.

Assim, não podemos deixar de traçar, mesmo que de forma sumária, o trajeto dessa produção visual inicial, totalmente ligada à expressão das várias tendências da vida cultural que a editora também encarnou e que permitirá ao designer acumular experiência e autoridade para realizar uma intervenção mais profunda nos demais segmentos de atuação da editora, incluindo o economicamente mais importante, o do livro didático. Conhecer essa produção é também importante para permitir o confronto e a comparação entre soluções gráficas determinadas por problemas diferenciados de comunicação visual, enriquecendo a análise.

\subsection{Os livros não didáticos}

Dando início a esse panorama, o primeiro projeto encomendado foi a reformulação visual de capa e miolo da já existente série Bom Livro, dirigida por Jiro Takahashi. Para isso, Normanha propôs outro diagrama e nova linguagem de ilustração de capa, que deram um aspecto mais elegante e contemporâneo aos livros, embora estes continuassem populares em termos de preço, o que, junto com a ficha de leitura, consolidou a penetração escolar da coleção, em detrimento das concorrentes Saraiva, Melhoramentos e Ediouro (BORELLI, cit., p. 106-107). A ilustração ocupava quase dois terços na parte inferior do campo, e o título do livro e o nome do autor em tipo serifado bold condensado ficavam centralizados no terço superior, de fundo preto. Muitas ilustrações foram atribuídas a Jayme Leão, um dos ilustradores do jornal Movimento e da revista IstoÉ.

A coleção seguinte que a editora lançou para atender a demanda por literatura juvenil paradidática foi a Vaga-lume, ainda em 1972. Também dirigida por Jiro Takahashi, foi buscar autores brasileiros e temáticas de aventura para o público de primeiro grau, que tinha pouco interesse pelos autores do século XIX. A renovação

40 conjunto dessa obra mereceu 0 aprofundado estudo de Sandra Borelli (1997, cit.), aqui utilizado como uma das fontes sobre a história da editora, que revela as relações entre criação autoral, indústria e mercado cultural no Brasil. do projeto e a edição de arte foi assumida por Ary Normanha, que define a linha das ilustrações a partir dos originais e consulta ao editor. Nos anos 1980, a série evolui para temáticas urbanas, sempre de mistério, suspense e ação, e tem como principal autor Marcos Rey, que constrói uma fórmula ficcional de grande sucesso comercial para a editora. ${ }^{4}$ 

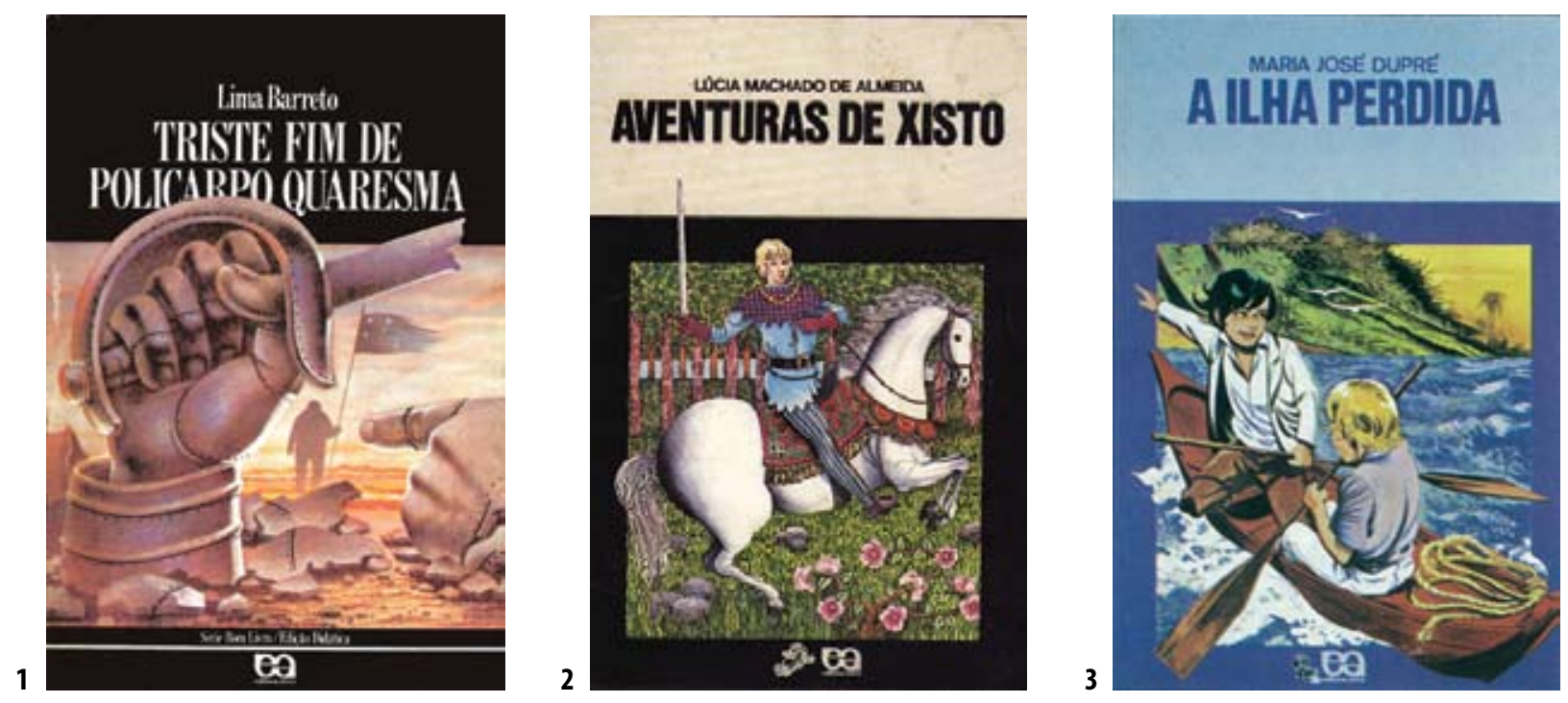

Ainda voltado para a faixa etária do segundo ciclo do ensino primário, a editora lançou em 1977 a série Para Gostar de Ler, projeto de Jiro Takahashi, constituída de antologias de crônicas de autores brasileiros como Carlos Drummond de Andrade, Fernando Sabino, Rubem Braga e Paulo Mendes Campos. Como a seleção de crônicas, organizadas por temas, foi o resultado de uma pesquisa com uma edição não comercial que envolveu cerca de mil alunos de diversos níveis sociais, revelando a mencionada profissionalização da editora, o sucesso foi muito grande, e a partir do sexto volume outros gêneros foram contemplados, como poesia e conto (PAIXÃO, 1995, p. 225-226). O projeto gráfico de Ary Normanha previa muitas ilustrações internas, caricaturas e capas com ilustrações sugestivas e atraentes, que ficaram a cargo de Mário Cafiero, responsável pela marca visual da coleção.

Também são de Normanha os projetos gráficos das coleções Autores Brasileiros e Nosso Tempo, organizadas por Jiro Takahashi, que fizeram da editora participante agressiva do chamado "boom editorial de 1975", marcado pela grande expansão do conto e do romance-reportagem, num contexto de crise econômica com consequências políticas para o regime e a sociedade, conforme Holanda e Gonçalves:

Os espaços que são conquistados, a retomada gradual do debate político mais aberto, a própria crise que cada vez mais se faz presente despertam um grande interesse pela política, notadamente entre a juventude urbana e setores médios que constituem o público consumidor de cultura.

Surgem, portanto, condições para a consolidação de um mercado ou de uma faixa de mercado para a produção cultural nacional de dicção política. (cit., p. 113)

[...] É, provavelmente, essa percepção (nem sempre presente nos produtores de cultura) que leva o mercado editorial à oportunidade de abrir campo para as "obras de esquerda". E sem dúvida, nesse momento, com esquemas de distribuição apurados, técnicas de marketing mais modernas, como melhores capistas, divulgação e até recursos como "fichas para leitura", as editoras se capacitam no sentido de criar ou dinamizar o mercado potencial da literatura. (cit., p.118-119) ${ }^{\mathbf{5}}$

Não há dúvida que o último paragráfo refere-se aos procedimentos da Ática, que lança novos autores, como Abel Silva, Roberto Drummond, Antonio Torres e

1 Novo projeto da Bom Livro, de Ary Normanha. llustração de Jayme Leão.

2/3 Livros da Série Vaga-Lume, projeto de Ary Normanha. Ilustração de Mário Cafiero e ?

\footnotetext{
$\mathbf{5}$ No texto citado, os autores analisam e criticam a abordagem neonaturalista de viés populista de parte dessa literatura, particularmente 0 romance-reportagem, ao mesmo tempo que apresentam outras vertentes que dela se diferenciam pelo investimento na pesquisa de linguagem e também marcam a literatura dos anos 1970.
} 

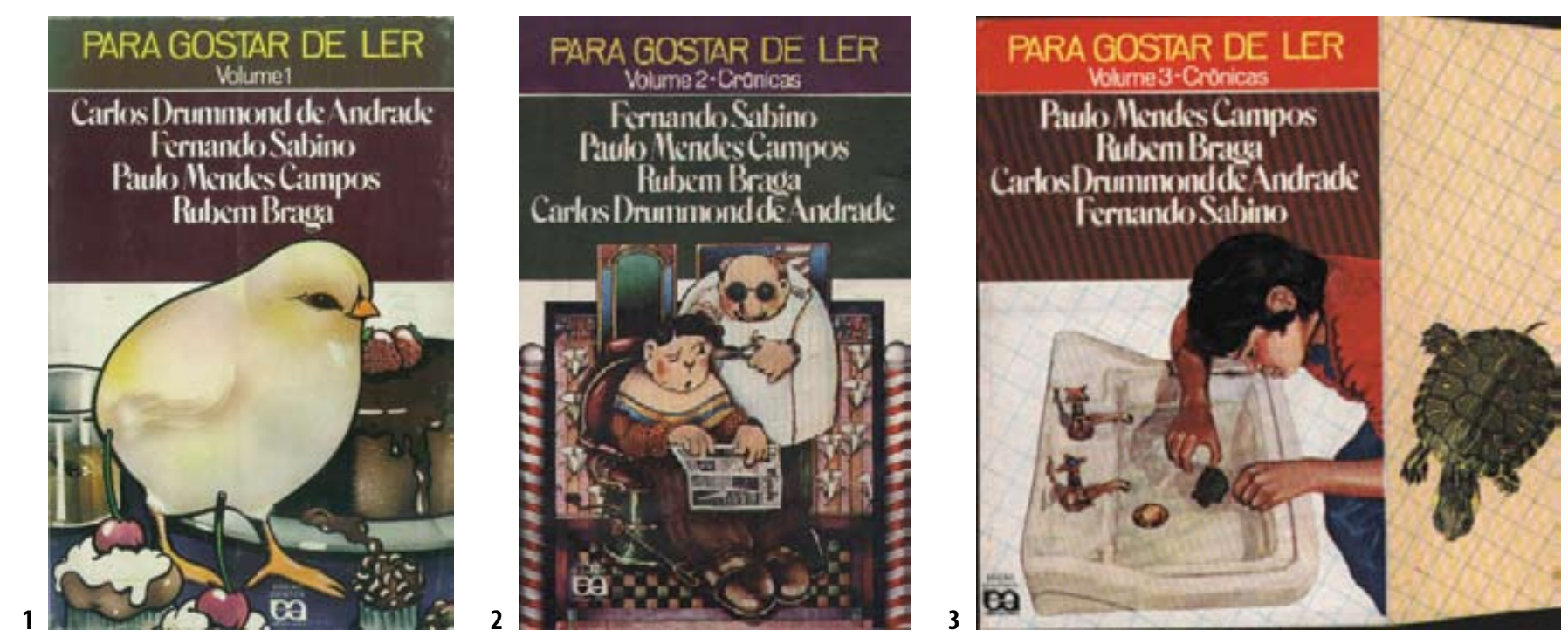

1/2/3 Para gostar de ler. Volumes 1, 2 e 3 . Edição de arte Ary Normanha e Mário Cafiero. Capa e ilustrações Mário Cafiero. Década de 1970.
Luís Vilela, dentre muitos outros, e mesmo alguns já veteranos, ampliando sua projeção, como Dyonelio Machado, Moacyr Scliar e Murilo Rubião. A coleção Nosso Tempo, além do projeto gráfico de Ary Normanha, recebe ilustrações do já reconhecido artista gráfico Elifas Andreato, que Ihe dá forte identidade visual, apesar da diversidade de técnicas e de traço que emprega, não só nas capas coloridas, mas também nas ilustrações em preto e branco de página inteira de miolo. Seu traço inconfundível, mesmo diferenciado pela grande versatilidade de materiais, técnicas e imaginação, em ilustrações que utilizam uma abordagem ainda mais metafórica e onírica dos temas que a utilizada nas publicações engajadas de que participava, como os jornais Opinião e em seguida Movimento, não deixava de incorporar a coleção nessa visualidade que abrangia toda uma produção cultural genericamente identificada como de oposição ao regime, que ia das publicações diretamente políticas às capas de disco e cartazes de teatro e espetáculos musicais. ${ }^{6}$

Um segmento didático ainda pouco explorado pelas editoras brasileiras no início da década de 1970, considerando a grande expansão da rede de ensino, tanto particular quanto oficial, foi o de terceiro grau. Com projeto de José Adolfo de Granville Ponce, apresentado ao professor Antonio Candido, a editora forma um conselho editorial que inclui também Alfredo Bosi, Aziz Simão, Flavio di Giorgi, Ruy Coelho, Rodolfo Ilari, Haquira Osakabe entre outros, e planeja a coleção Ensaios. O primeiro título, No calor da hora, de Walnice Nogueira Galvão, sai em 1975, seguido de outros que também se tornaram clássicos da produção acadêmica editados como livros e divulgados para o público universitário, como Ideologia da cultura brasileira, de Carlos Guilherme Mota, e O escravismo colonial, de Jacob Gorender (PAIXÃO, cit. p. 230-231). O projeto de Ary Normanha, mesmo tendo como referência e utilizando a mesma abordagem encontrada na coleção Debates, da Editora Perspectiva, propicia forte identidade visual à coleção sem comprometer a sobriedade esperada de textos resultantes de pesquisa acadêmica.

No início dos anos 1980, duas novas coleções serão criadas para o público universitário, a série Princípios e a série Fundamentos, com projeto também de Ary Normanha de capas exclusivamente tipográficas. 

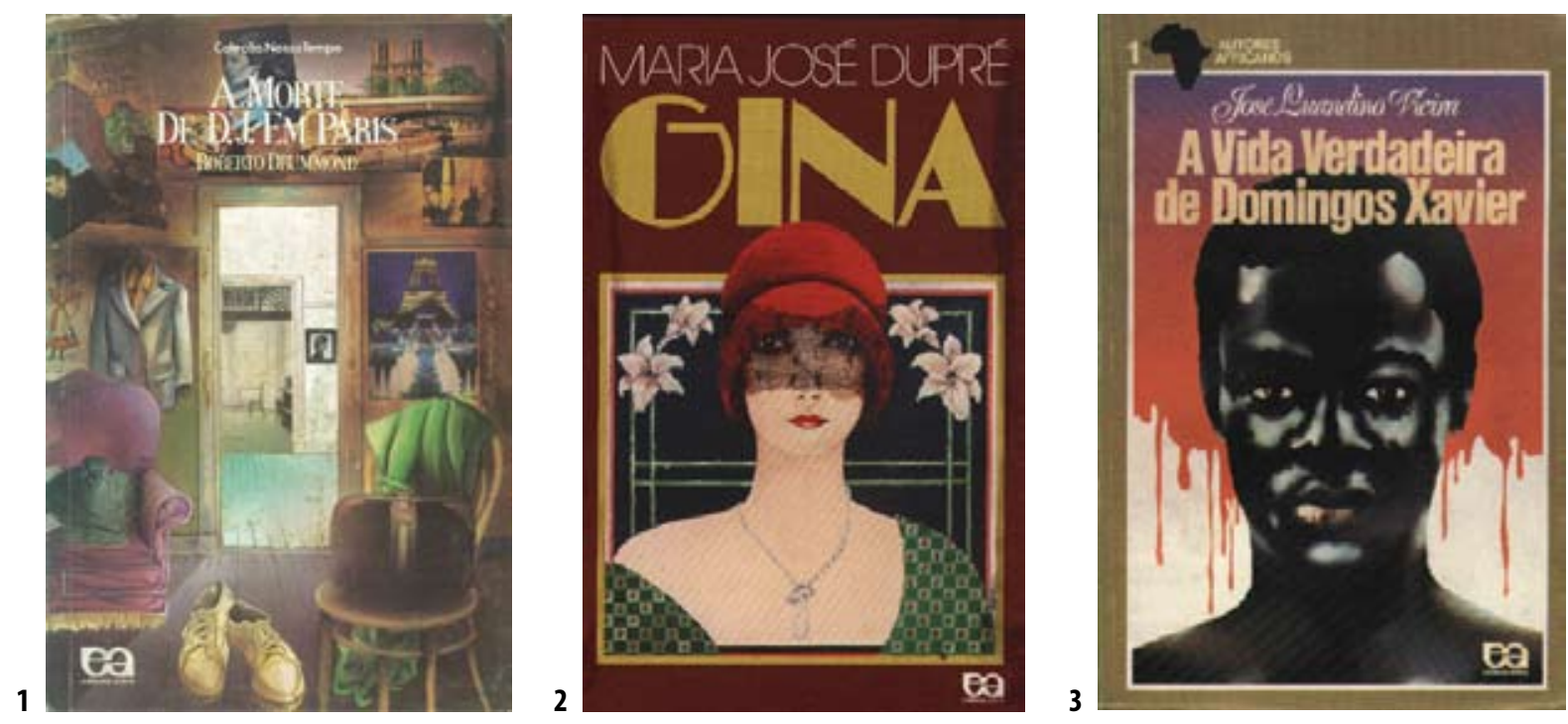

No início da década de 1980, a coleção Autores Africanos, uma iniciativa inédita no país, revela a importante produção literária do continente, com a edição não de autores só em língua portuguesa mas também com traduções do inglês e do francês. O projeto e as ilustrações de capa são de Mário Cafiero.

Embora outros projetos de coleções e livros avulsos foram realizados por Normanha, as realizações apresentadas já são suficientes para nosso propósito de situar, tanto cronologicamente como em termos de linguagem, sua produção posterior voltada exclusivamente para o livro escolar, objeto deste trabalho. Fica assim claro que, num primeiro momento, a contratação de um designer com trânsito nas linguagens de comunicação de massas mais atualizadas foi necessária ao projeto da editora Ática de se lançar nas áreas da cultura mais amplas, que a sociedade brasileira demandava. E deverá também ficar claro que foi essa experiência o que permitiu aos dirigentes da editora pretender estender essas linguagens para seus livros didáticos.

\subsection{A procura de uma linguagem para os dois atores do universo escolar, o aluno e o professor}

Como vimos na Parte I, o tratamento gráfico dado ao livro didático era bastante convencional e seguia procedimentos já estabelecidos na indústria mais tradicional do livro, com as poucas exceções apontadas. Mais do que isso, parece mesmo ter havido uma queda na qualidade visual e até na produção gráfica (impressão e acabamentos) nas obras das novas editoras, que não contavam com a mão-de-obra experiente de uma editora consolidada como a Nacional, por exemplo. No caso da Ática, a situação não era diferente, embora sua jovem equipe procurasse inovar e tornar a diagramação mais interessante e leve para os estudantes, não contava com profissionais com formação em edição de arte e editorial para solicitar, avaliar e escolher as melhores soluções. Na verdade, sem uma preparação profissional anterior, todos se encontravam em processo de formação no exercício da própria atividade.

6 Essas várias vertentes da significativa obra de Elifas Andreato pode ser confrontada em seu livro Impressões (1993), que reúne trabalhos do início da carreira até 0 início dos anos 1990. 

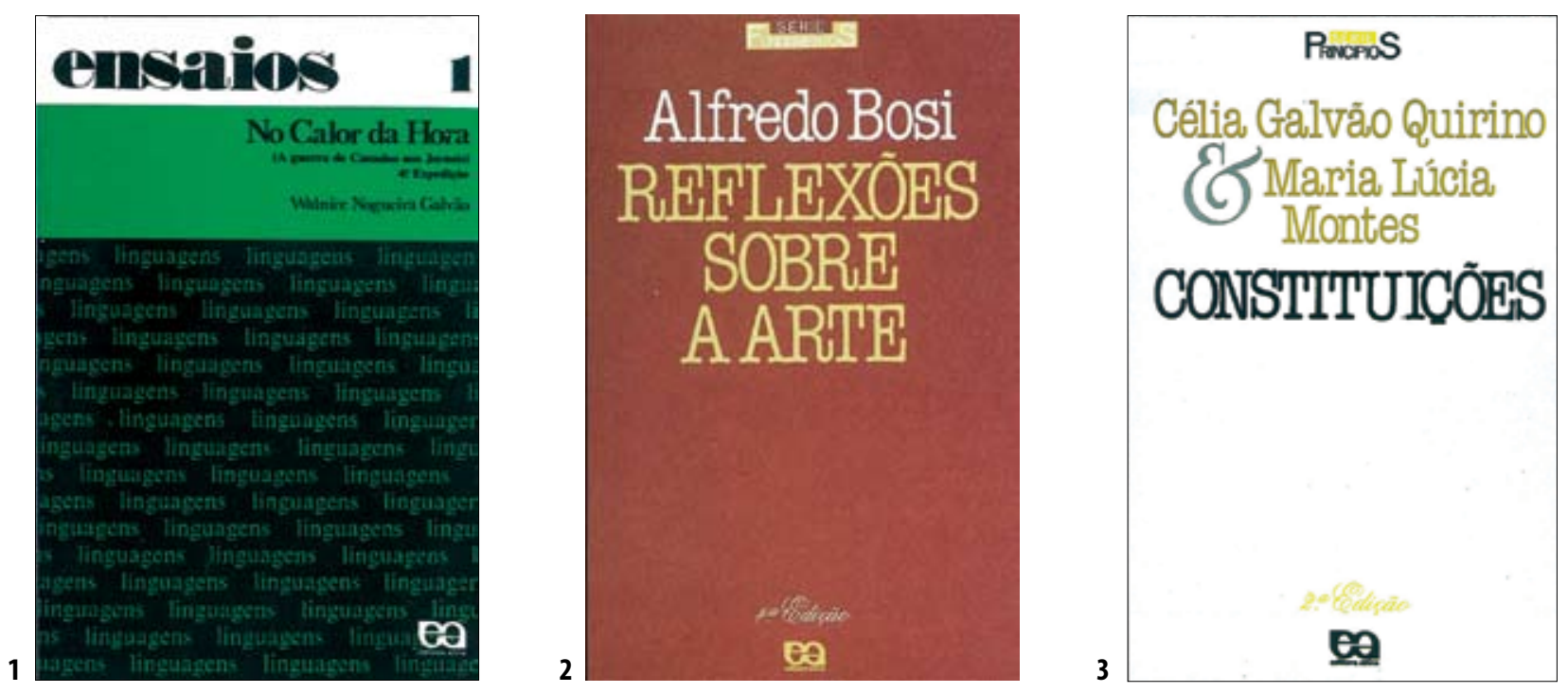

1 Volume da Coleção Ensaios. Capa e miolo Ary Normanha. Década de 1970.

2 Volume da Série Fundamenos. Capa e miolo Ary Normanha. Década de 1980.

3 Volume da série Princípios. Capa e miolo Ary Normanha. Década de 1980
Em depoimento, Irami Silva conta como, após contratado para trabalhar no departamento de arte da editora mas sem ter grande experiência anterior, foi enviado pela direção da empresa para fazer estágio em editoras sediadas em Paris e Londres, o que demonstra a preocupação com a profissionalização de suas equipes por parte principalmente de Anderson Fernandes Dias.

No campo da publicidade e da edição de arte das revistas de maior tiragem ou expressão cultural, a profissionalização já havia chegado, de forma que parecia haver um fosso entre a linguagem dessas publicações e a do livro escolar. O design de revistas como Bondinho, particularmente o do segundo período, era francamente experimental se comparado com o livro didático então produzido. Além disso, atribuía-se ao público e à instituição escola um conservadorismo que conduziria a um desinteresse e mesmo rejeição a eventuais novidades estéticas, desobrigando as editoras de qualquer investimento no sentido de uma equiparação de seus produtos aos das demais mídias impressas. Na verdade essa questão sequer se colocava na maioria dos casos, pois eram os corpos gerenciais e editoriais dessas empresas que, refletindo uma situação geral da cultura e da educação no país, não tinham formação e informação visual que permitissem iniciativas nesse campo.

Assim, não deixa de ser mais uma manifestação de busca de profissionalização e modernização que caracterizou a gestão de Anderson Dias à frente da Ática mencionada em todos os depoimentos obtidos e confirmada por atitudes como a contratação de Ary Normanha, que do trabalho como freelancer passa a assumir a responsabilidade de fazer também as capas dos didáticos.

Segundo afirma retrospectivamente, Ary Normanha procurou fazer uma caracterização mais precisa do problema que constituiriam as capas dos livros didáticos. Considerava que os livros didáticos da época, inclusive os que conhecera como estudante, tinham até qualidades de texto na exposição dos conteúdos, procuravam envolver o leitor, mas isto não era acompanhado pela sua visualidade e principalmente não se expressava na capa. A seu ver, partindo de que era o professor que escolhia as obras, as editoras se acomodavam numa visão de que os critérios para a adoção diziam respeito apenas ao conteúdo textual e elas não pre- 
cisavam ter uma despesa a mais. Nesse contexto, considerava que os livros da Ática já procuravam uma diferenciação, pois utilizavam quadrinhos e imagens do universo juvenil, mas, mesmo assim, sua linguagem era bastante defasada em relação ao que o jovem encontrava nas revistas e outros veículos, além de ser executada por profissionais que não dominavam essas linguagens. As capas, quando muito, eram corretas como composição, mas antiquadas no uso da tipografia e da imagem e decididamente estavam distantes da visualidade que professores e estudantes encontravam em outros meios de comunicação (NORMANHA, 2008).

Para Ary Normanha, as capas deveriam causar impacto no professor, convidá--lo a conhecer o interior do livro e se interessar por seu conteúdo como passo fundamental para decidir por sua adoção. E deveriam ser de agrado do aluno e se identificar com seu universo visual, como fator de motivação e interesse pelo estudo e pela escola ${ }^{\mathbf{8}}$. Cafiero menciona haver uma compreensão tácita, não expiícitada, de que, se o livro iria acompanhar o aluno um ano de sua vida,"tinha de ser legal", o que resultava num compromisso de todos os envolvidos com essa premissa. A resposta a essas formulações seriam a busca da novidade, da introdução de uma solução nova, e teria como base o olhar de quem trabalhara em periódicos destinados a diversos tipos de público e também com a visualidade mais inovadora experimentada na comunicação de massas no país.

A principal solução que Ary Normanha e Mario Cafiero propuseram - mas que em depoimento o primeiro salientou que foi amadurecendo e se aperfeiçoando tanto no conceito como na realização - foi a do uso da fotografia de montagens tridimensionais que reuniam objetos e imagens referentes ao conteúdo didático das disciplinas, identificados a partir da leitura atenta dos originais e para fugir às fotos prontas e a que todos tinham acesso, fornecidas pelos bancos de imagem. De fato, as primeiras capas fotográficas utilizavam apenas um ou dois objetos, mas estes eram produzidos com bastante cuidado e apuro e os efeitos fotográficos exigiam trabalho profissional que nada ficava a dever ao melhor encontrado em revistas e publicidade. Esta solução, além de ser uma resposta original à comunicação específica do tema didático, era também inédita nos livros em geral, e os primeiros exemplos dela teriam causado forte impacto no público.

Se talvez seja exagero atribuir a essas capas parte da intenção de construir uma política de visualidade da editora com vistas ao estabelecimento de uma imagem de modernidade e inovação no mercado e na sociedade, é preciso reconhecer que seu custo e complexidade implicava algum grau de deliberação e planejamento. Por envolver uma produção lenta e trabalhosa, que incluía modelagem em argila ou gesso, confecção de peças em acrílico e madeira, pintura de telas, aerografia, solda etc., sua produção não poderia se limitar à realização de poucas capas, e a questão de escala se colocou desde o primeiro momento.

Mesmo dividido entre várias obras, o custo dessa produção era bastante elevado e incidiria sobre o preço de capa de cada título. Apenas o sucesso comercial obtido, com a venda de grandes tiragens, pode explicar a ampliação e consolidação do departamento de arte que se seguiu, com a contratação de novos profissionais e a construção de uma organização espacial mais adequada. Ary Normanha
8 Como há uma disjunção entre 0 contexto de produção e o de recepção, a relação entre ambos é mediada pelo objeto gráfico. 0 produtor não tem como conhecer todo o espectro de visualizadores, e por isso sempre vai trabalhar com uma imagem mental deles e da maneira como verão e interpretarão suas criações (KRESS; LEEUWEN, 2008, p. 114-116). 
teria obtido da diretoria a derrubada de paredes de parte de um andar na primeira sede da editora e a construção de móveis que ele mesmo desenhou, para permitir o trabalho coletivo, que era a experiência que trouxe dos tempos do jornalismo e considerava fundamental para o resultado pretendido.

Sobre a dinâmica de produção dessas capas, Normanha informa que havia um projeto para diversas capas, de onde saía a atribuição dos objetos que cada um iria executar, mas, à medida que eles iam sendo produzidos, o confronto entre eles ia permitindo o aperfeiçoamento do conjunto e mesmo modificações do projeto inicial, num processo de avaliação e julgamento muito rico e que envolvia todos. Assim, não só profissionais já reconhecidos e experientes, mas também aprendizes indicados por colegas da empresa ou profissionais ainda em formação conviviam e trabalhavam nos mesmos projetos e tiveram oportunidade de se desenvolver. Segundo Ary Normanha, uma condição para a boa realização dessas capas foi o conhecimento que adquiriu nos tempos de secretaria gráfica das publicações anteriores, quando incorporou "a tabela de cores na cabeça" e aprendeu todo o processo de pré-impressão, sabendo o que era possível e como indicar o que desejava para o profissional do fotolito.

\section{Outras linguagens das capas}

Embora as primeiras capas planejadas por Ary Normanha e Mario Cafiero tenham sido as montagens fotográficas de diversos tipos - com as caixas com objetos tridimensionais formando um conjunto bastante significativo - , que deram uma certa identidade aos títulos da área de língua portuguesa principalmente, outras soluções apareceram durante sua permânencia à frente do departamento de projetos especiais até meados da década de 1990.

No entanto, é bastante difícil encontrar um critério único para proceder a uma classificação que não seja excludente, por exemplo a linguagem gráfica em si (predomínio da ilustração, da fotografia, da tipografia) ou o segmento disciplinar e faixa etária. No primeiro caso, as linguagens podem aparecer misturadas e com grande liberdade de tratamento, como veremos com as capas de Língua Portuguesa; no segundo caso, embora haja a predominância de algumas soluções para algumas disciplinas, ela não é constante e esse critério acabaria por excluir algumas capas significativas.

Mesmo uma classificação exclusivamente conceitual, não dependente da linguagem e dos materiais utilizados, mas que separasse as capas em conteudísticas (voltadas para comunicar o conteúdo do volume ou da disciplina mediante reprodução de imagem associada a ele ou nele contida), metafóricas (associações mais livres e indiretas), ou simplesmente expressivas (predomínio da expressão gráfica), seria arbitrária.

Na verdade, as abordagens propostas foram bastante variáveis e, segundo Normanha, se deveram ao contato com os originais e o conteúdo das disciplinas e volumes, à sua própria experiência escolar e às características que intuía de cada segmento do público. A primeira questão, já mencionada, era que as capas deveriam chamar a atenção e satisfazer expectativas do professor e, ao mesmo tempo, 
agradar e cativar o aluno. Segundo o designer, uma parte importante das expectativas do professor dizia respeito à capa portar significados relacionados à disciplina. Esses significados poderiam ser mais genéricos e livremente alusivos ou mais explícitos e diretos, em relação tanto à disciplina como ao conteúdo do volume em questão, e dependiam de características que via nos professores. Essas características não foram formalmente pesquisadas, a não ser na década de 1990, mas aí foram mais ou menos confirmadas.

Assim, para professores de inglês, a solução de expressar características gerais das culturas britânica e americana através de metáforas e humor e em linguagens bem calcadas na cultura de massas e até mais ousadas era um caminho bastante seguro, pois, considerava Normanha, eram professores mais abertos. Na disciplina de Língua Portuguesa, segundo o designer, havia bastante espaço para capas metafóricas e relativas a aspectos genéricos do conteúdo, sendo que nos primeiros anos poderia haver maior apelo ao lúdico e a referências da literatura e da vida infantil. Em Matemática, conteúdos genéricos da disciplina poderiam ser expressos, principalmente nos primeiros anos, mas, com o curso se dividindo nas várias áreas, as capas já deveriam traduzir esses conteúdos de maneira mais explícita. Em Ciências exatas e biológicas, e particularmente no segundo grau, os conteúdos precisavam aparecer nas capas até como forma de identificação do volume. Em História, o aspecto documental também era bastante valorizado pelos professores. Esses são, genericamente, alguns julgamentos e abordagens que veremos mais em detalhe ao analisar as capas.

Além dessa expectativa de conteúdo, em si já bastante variável, está a questão das linguagens capazes de agradar a professores e também a alunos. Aqui, como vimos, tanto alunos como professores não foram vistos como espécimes pertencentes a um espaço e a uma cultura isolada, a escolar, mas como indivíduos que recebem informações de todos os lados e por todos os meios de comunicação. Assim, mesmo os conteúdos mais restritos não poderiam ser expressos nas linguagens de representação gráfica criadas pelas disciplinas nem através de um repertório de imagens já excessivamente explorado e automaticamente associado a elas. As abordagens gráficas procurarão sempre apresentar os conteúdos de maneira a surpreender, a quebrar expectativas, e o lúdico tem um papel importante, principalmente no ensino fundamental.

Portanto, com todas essas considerações, uma classificação será necessariamente híbrida, misturando os vários critérios expostos, porque imposta pela realidade concreta das capas, e só se justifica para permitir uma ordem de apresentação das capas. Assim, com todas as ressalvas feitas, as capas serão apresentadas na seguinte sequência:

1. montagens fotográficas;

2. ilustração e fotografia referencial;

3. cartum ou ilustração de humor;

4. tipografia. 


\section{AS CAPAS DOS LIVROS DIDÁTICOS}

\subsection{As montagens fotográficas}
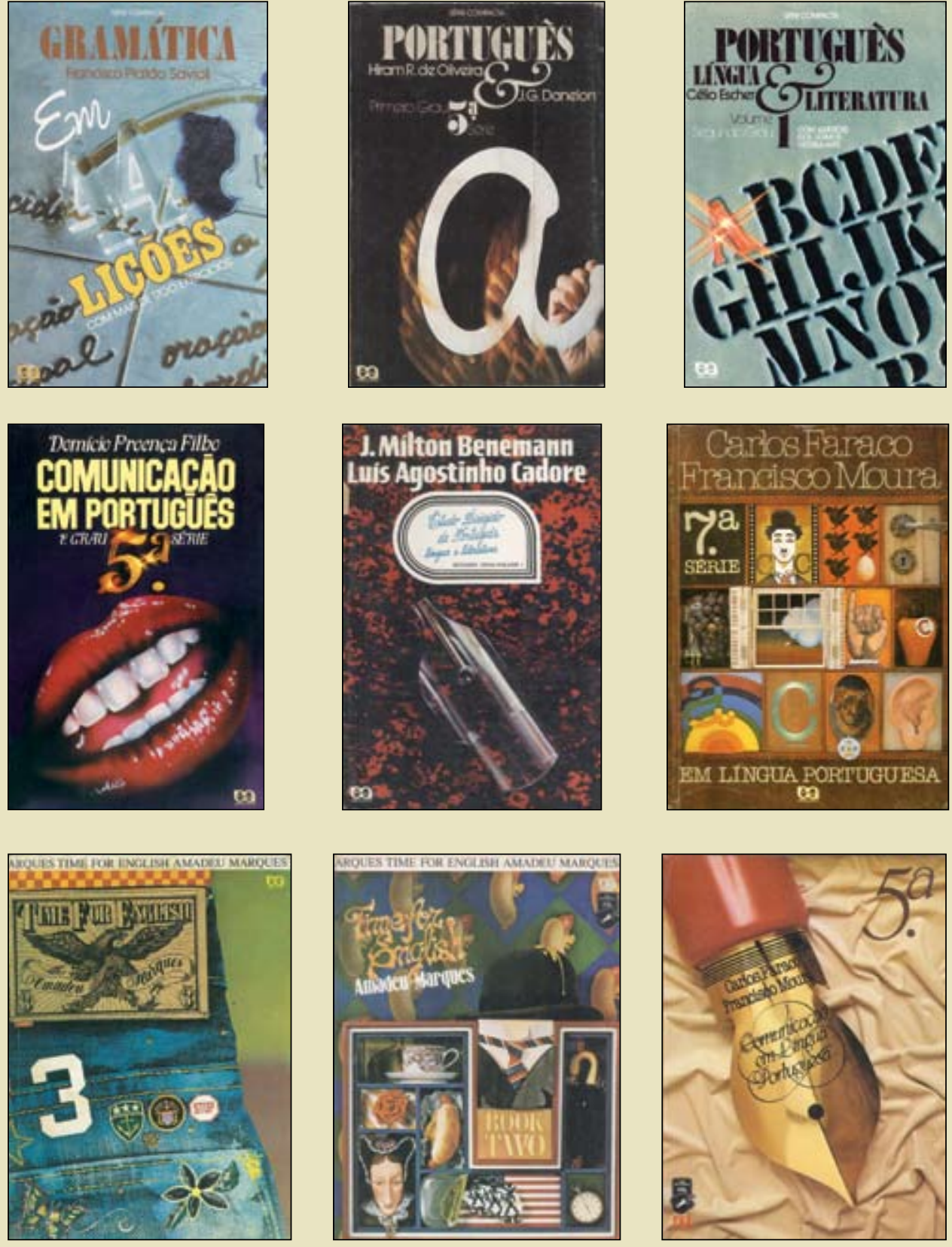

Esse conjunto de capas tem como princípio básico para a construção do significado e a comunicação com seu público a referência à realidade propiciada pela fotografia. Em princípio elas falam do mundo real, não de um mundo criado pela imaginação ilimitada que uma ilustração pode trazer. São objetos concretos, materiais, com volume e características de superfície acentuadas pelo domínio técnico da linguagem fotográfica. 
Com a presença da televisão, das reportagens fotográficas e principalmente a publicidade em veículos impressos com uma qualidade gráfica já presente desde os anos 1960 e aperfeiçoada nos anos 1970, um novo padrão de realismo faz parte do cotidiano da vida dos brasileiros. É claro que esse realismo é construído pelos novos dispositivos técnicos como uma representação do real, não como um duplo igual ao real efetivamente percebido (que também pode ser questionado como real). As diversas correntes da pintura dos séculos XVI ao XIX e a fotografia em preto e branco já foram socialmente tomadas como absolutamente realistas, sendo que no último caso nem a cor presente na percepção do mundo aparecia. A fotografia é também uma linguagem de representação, e, portanto, de interpretação do real e de construção do simbólico. Mas essa capacidade de criar uma correspondência iconológica dos objetos do mundo a partir da captação de sua luz e impressão numa superfície sensível, ou seja, um fenômeno natural aparentemente sem manipulação de mente e mãos humanas, reforça o poder da fotografia e a impõe como novo padrão de representação realista do real.

No entanto, o realismo fotográfico, já presente e decodificado pelo público brasileiro em geral, curiosamente pouco aparecia nas capas de obras didáticas, o que marca a distância entre o design desse produto e o de outros já amplamente consumidos, particularmente na publicidade de revistas, para não falar da televisão, com transmissão em cores generalizada na segunda metade da década. Os exemplos já mostrados de capas fotográficas na Parte I são feitos com tão pouco cuidado e com tecnologia de reprodução tão defasadas que não parecem fazer parte do mesmo mundo da comunicação de massas experienciado por todos.

Mas o que de fato torna essas capas significativas para o público não é conterem meras fotografias, mas fotografias em que as qualidades "fotográficas", isto é, que caracterizam a fotografia como linguagem, são evidenciadas. O que é fotografado não é uma situação ou objeto real conhecido ou encontrado, pois se trata de montagens ou situações deliberadamente artificiais. O que tem apelo de realidade são a textura das superfícies, a volumetria, o efeito da luz incidindo, refletindo ou atravessando os objetos, a materialidade do mundo segundo a fotografia.

Esse é o assunto plástico dessas imagens, novo na época para o público e adequado para o objetivo e o contexto comunicativo em questão, como veremos em cada capa analisada. Integrado a informações textuais como títulos, nome dos autores etc., esse assunto plástico constituirá uma abordagem de design usada em todo um grupo inicial de capas da editora Ática que contribuiu para criar uma marca de linguagem que a diferenciou das demais concorrentes. 
Gramática em 44 lições. Platão Savioli.

4. ed., 1981.

Design Ary Normanha, Mário Cafiero e

Wanduir Durant. Foto de Sérgio Tegon.

$(21,7 \times 14,7 \mathrm{~cm}$;

plastificada e com orelhas.)

Capa e quarta capa.
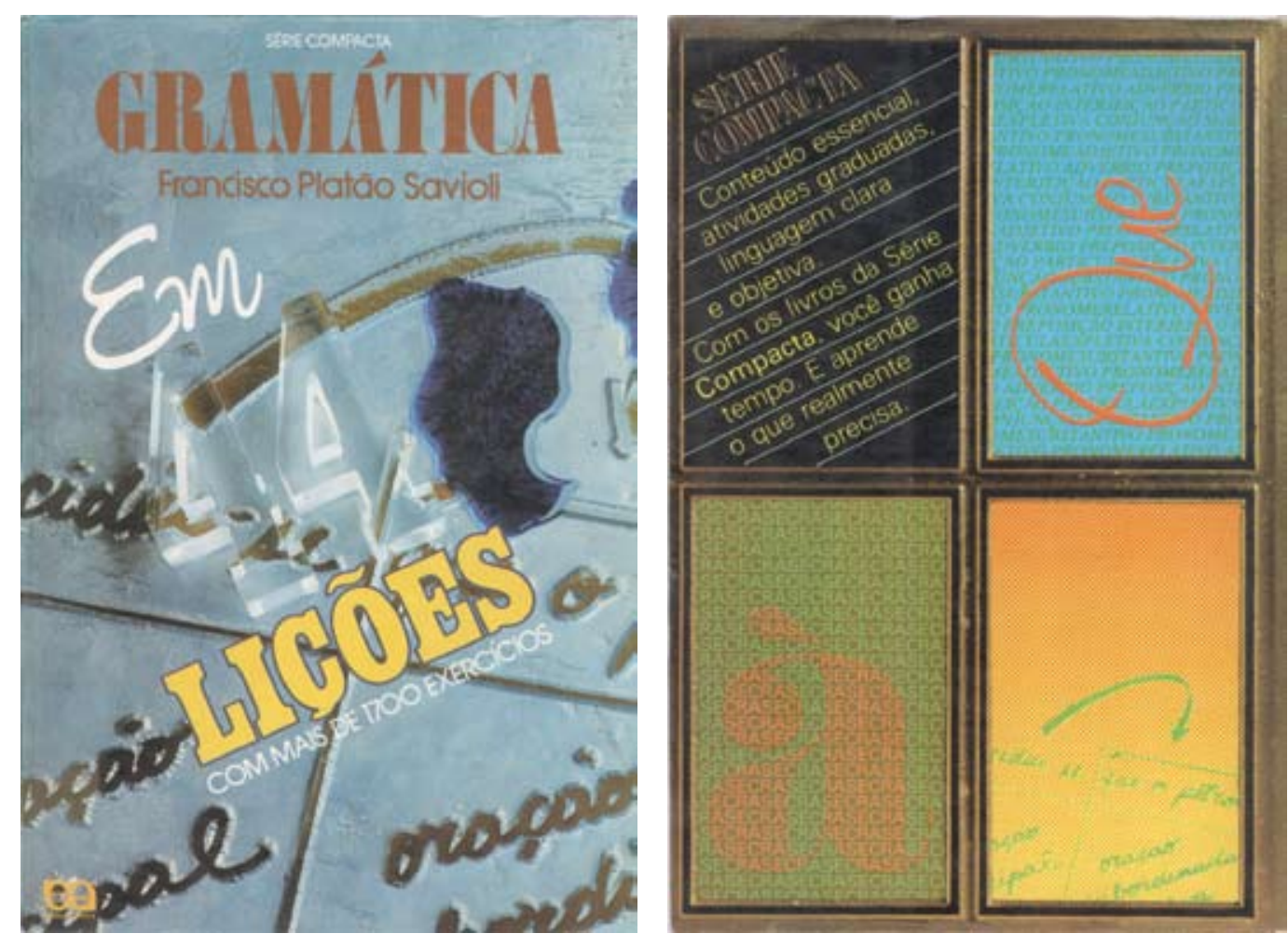

\section{Gramática em 44 lições - Platão Saviolli}

Aqui a fisicalidade da superfície gravada, o efeito de transparência dos algarismos e da gota de tinta são os elementos evidentes do realismo fotográfico da capa. No entanto, os objetos em si não existem, foram criados, e o arranjo feito com eles é claramente artificial.

O elemento do real seria o trecho fotografado de um esquema manuscrito de análise sintática de um período, com sua divisão em oração principal e oração subordinada, e que estabeleceria a representação lógica do conteúdo presente no interior da gramática, aliás, de qualquer gramática.

No entanto, não se trata da fotografia de uma lousa escolar ou de uma folha de caderno, mas de algo completamente fora do universo conceitual e imagético de alunos e professores: a superfície metálica gravada com o quadro de linhas e os termos usados em análise sintática é proveniente da tecnologia de gravação em clichê usado na impressão tipográfica. Além de a tipografia já ter sido praticamente substituída pela impressão offset, num clichê tipográfico real o texto estaria invertido, espelhado, para permitir que sua impressão no papel gerasse um texto positivo, legível. Esses elementos foram buscados em um repertório tecnológico desconhecido do público e são na verdade mero pretexto para uma construção visual que surtiria o efeito plástico pretendido, este, sim, com significado socialmente disseminado e valorizado: o da materialidade e da realidade veiculadas pela fotografia com aparência de alta tecnologia e modernidade.

Se a imagem é material, tátil, sua artificialidade a torna abstrata, conceitual. A ambiguidade entre o que pertence ao plano da fotografia - em que a chapa metálica não está totalmente frontal mas com leve perspectiva —, e ao plano do 
layout da capa, frontal, em que aparecem os componentes textuais, reforça a artificialidade e o significado conceitual, abstrato da capa.

A identidade dessa obra propiciada pela capa não é, portanto, resultado da referência ao conteúdo objetivo disciplinar — o esquema analítico de um período —- de resto, banal, genérico e sobretudo sem qualidades formais atraentes e interessantes. É de uma ideia visual externa a esse tipo conteúdo — e que trabalha com materiais, técnicas e sobretudo expectativas visuais do público - que surgem os significados capazes de criar apelo comunicativo e identidade da obra.

A disposição inclinada da segunda parte do título, composta em fontes e materiais diferentes e ocupando grande área no centro da capa, como elemento principal, em contraste com a primeira — a expressão "Gramática" — localizada de forma tradicional no alto do campo, seguida pelo nome do autor, conforme o padrão dos outros títulos da coleção (Série Compacta), produz um evidente truncamento linguístico do título verdadeiro. O efeito resultante é uma identificação inequívoca e forte da obra, em que o elemento que carrega a informação definidora de sua originalidade - Em 44 lições - ganha importância central. Uma suposta perda em exatidão formal é amplamente compensada pela eficiência comunicativa.

A diferença de fontes utilizadas na composição desse bloco do título - com o número "44" sendo um objeto sólido pertencente à fotografia de fundo e a informação de quantidade de exercícios fazendo parte dele - produz um desenho variado que fornece mais complexidade e interesse, sem impedir sua leitura. Contrariando os princípios da tipografia funcionalista, o designer utiliza a versatilidade propiciada pela tecnologia da fotoletra e das letras transferíveis (Letraset) para misturar os tipos em composições mais ricas e sugestivas. ${ }^{\mathbf{9}}$

A quarta capa segue o padrão da Série Compacta, uma moldura dividida em quatro áreas, das quais uma contém o texto promocional da coleção e as outras três particularizam a obra, mas sem muito compromisso formal com a solução da capa. Apenas um trecho maior da imagem da capa, mas com tratamento gráfico muito diverso, aparece no quadrante inferior direito.

Tanto a liberdade em misturar tipos como essa flexibilidade com os esquemas compositivos e padrões de identidade de coleções é outra característica do design de Ary Normanha, que se pode atribuir à sua formação autodidata nos departamentos de arte de revistas e não na academia e sob a égide do modernismo. Nunca um efeito estético ou eficácia comunicativa de uma composição visual serão sacrificados em nome de um sistema exterior e acima dela.

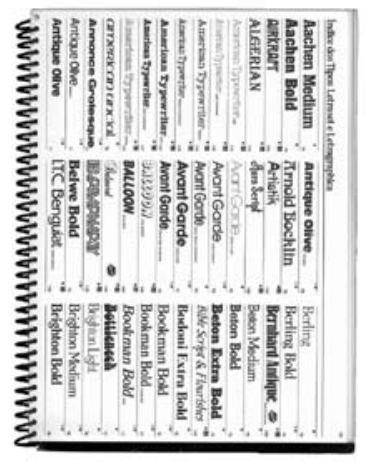

9 Essas tecnologias, quando surgiram, propiciaram uma liberdade no desenho de títulos que a composição a quente (linotipia) não permitia, pelos tamanhos e variedade de tipos oferecidos, mas principalmente pela flexibilidade de posicionamento no layout. A Letraset em particular, segundo Chico Homem de Melo, constitui uma verdadeira revolução no design, mudando suas características, por propiciar a designers, diagramadores e ilustradores um acervo de fontes totalmente à mão, sem depender de fornecedores de composição, e a possibilidade de integração com as imagens antes inexistente. 
Português. Hiram e

Danelon. 1. ed., 1980.

Design Ary Normanha, Wanduir Durant e José Góes. Fotografia Delfim Fujiwara. $(21,7 \times 14,7 \mathrm{~cm}$; com orelhas.)
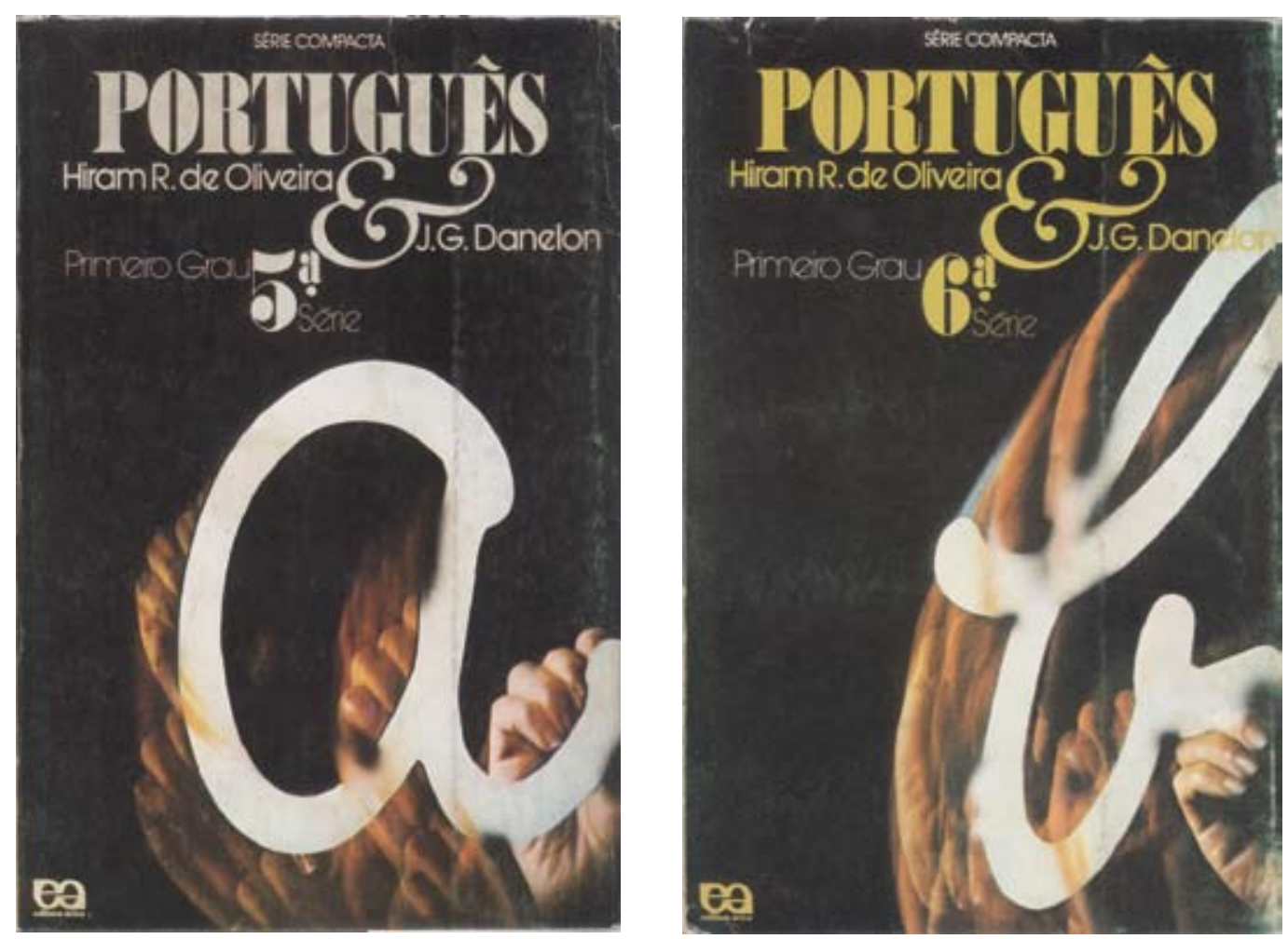

\section{Português - Primeiro Grau - Hiram e Danelon}

A titulagem dos volumes dessa coleção são um exemplo de como em design visual as informações textuais são construídas como formas, para serem vistas e reconhecidas como tal, antes de serem lidas "linguisticamente". Na verdade, a pregnância de formas construídas com o domínio da linguagem visual, em muitos casos até dispensa a leitura no reconhecimento da autoria do emissor de uma mensagem ou identidade de um produto, como vemos em logotipos ou páginas de publicações abertas a esmo.

Em que ordem o conjunto de informações textuais localizado no topo do campo da capa é de fato lida? O que é visto em primeiro lugar parece ser o título Português, o ampersand (e comercial) e o número da série, uma grande forma articulada que integra linhas de texto — os nomes dos autores e a informação de grau - e vazios do fundo penetrando de todos os lados, que participam tanto quanto o desenho das letras da configuração dessa forma tão particular.

A particularidade dessa forma é construída também pelo desenho das letras, pelo contraste desses desenhos, que se alternam nas linhas, e pelo ritmo visual resultante. A apreensão da capa incorpora a totalidade, o topo com as informações textuais e a imagem da parte inferior, que corresponde a dois terços do campo, uma grande letra da fotografia. Os dois são bem marcados, o da titulagem e o da fotografia, mas também bem relacionados, porque o principal da imagem fotográfica é também uma letra.

A fotografia mostra o movimento de desenho de uma letra feita por trás da capa, como se essa fosse um vidro (e de fato a letra estava desenhada em um vidro), e introduz o visualizador, que está na frente da capa, ao espaço da represen- 

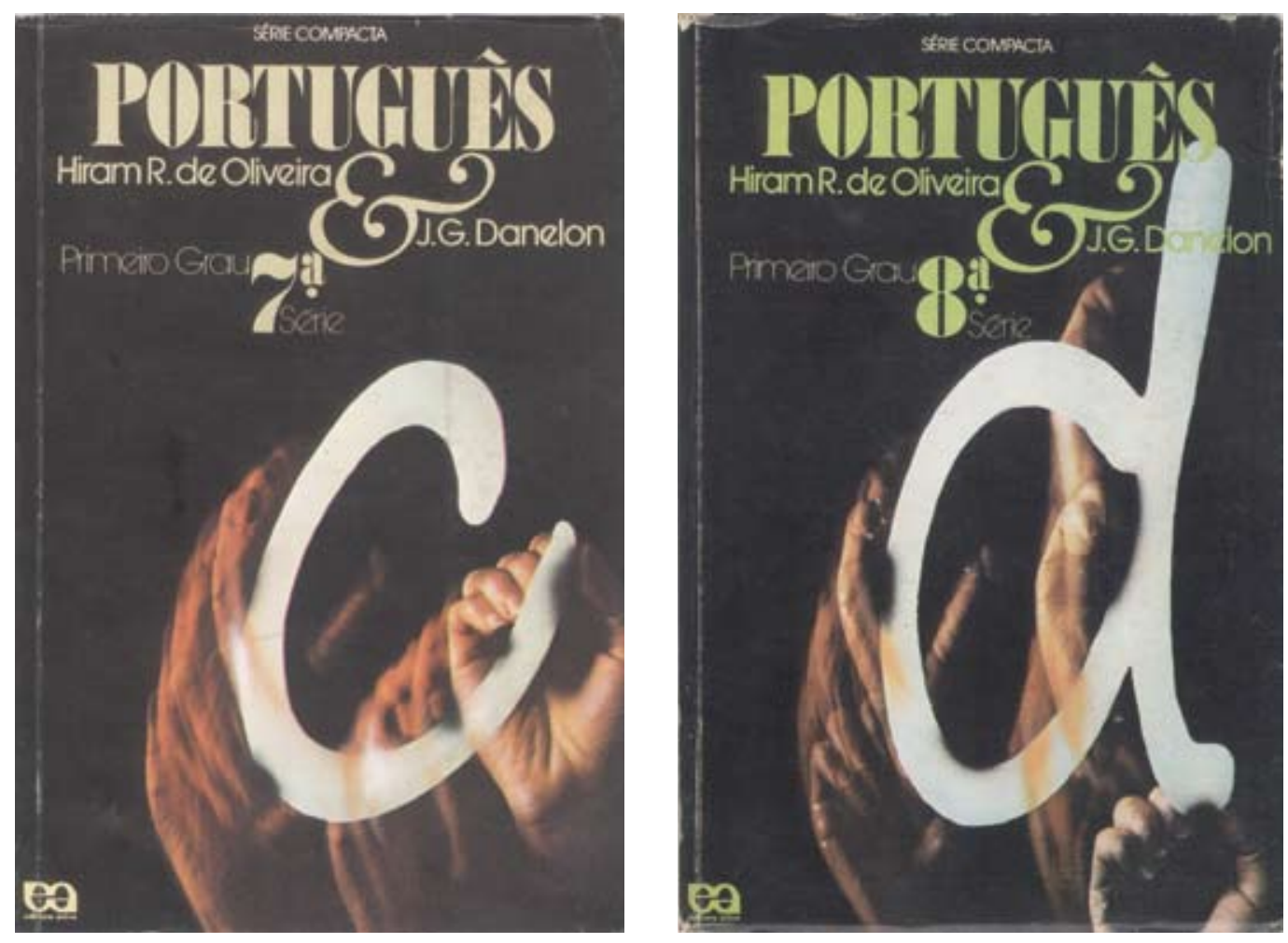

tação. Isto é, impõe a presença do visualizador à ação representada. Esse efeito é obtido pela frontalidade da imagem e pela equivalência entre a superfície que está sendo escrita e a superfície da capa.

O registro desse movimento se dá pela captura de momentos isolados que fazem parte da sequência total do movimento, com a imprecisão da imagem desses momentos intermediários, que culminam na imagem fixa e nítida do momento final da grafia da letra. Na verdade trata-se de uma simulação do movimento, que parece real porque apela para representações já decodificadas pelo público oriundas de seu conhecimento anterior de imagens do cinema e da fotografia. Assim, trata-se de referência a uma realidade que na verdade é construída como código dentro desse regime visual estabelecido pela imagem em movimento do cinema e da televisão e congelado na sequência fotográfica. Nesse caso, a letra já estava desenhada no vidro e a mão retraçou seu trajeto no momento da fotografia.

A ideia de progressão, que permite a identidade de cada volume da coleção, é dada pela sequência das letras iniciais do alfabeto nas quatro capas. Aqui se vê que o impacto da solução gráfica não se deve a uma ideia exterior à sua realização, a uma ideia do raciocínio "linguístico", que no caso pode até ser considerado bastante óbvio e pueril, "traduzida" para meios visuais. A força comunicativa está na ideia gráfica em si, que depende de sua realização material, com os "materiais" da linguagem visual. Ou seja, a ideia pertence ao domínio do design,

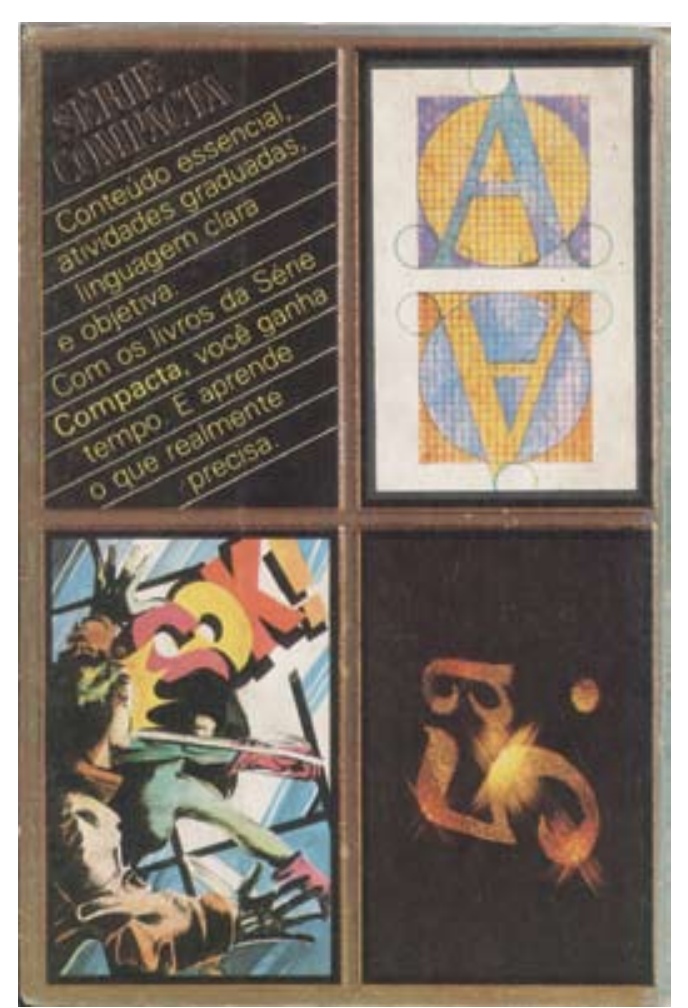


e não do raciocínio verbal escrito. O significado geral resultante é que faz referência à escrita como modo de comunicação e diz que se trata de um livro didático da língua pátria.

As quartas capas seguem também o padrão criado para a Série Compacta, com uma particularização de cada volume feita com ilustrações em diversas linguagens, por vários colaboradores, sem grande preocupação de coerência de conteúdo entre elas, ou melhor, com a preocupação com o resultado plástico.

\section{Português: Língua \& Literatura - Célio Escher}

O que foi dito sobre o trabalho gráfico com as informações textuais para a obra Português, de Iram e Danelon, vale também aqui. Por ser a imagem fotográfica da parte inferior também constituída por letras, como se garante o significado atribuído a cada parte, a inferior e a superior, na construção do significado total da capa, conforme os procedimentos e regularidades apontados no tópico 3 da Parte 1?

As informações de identidade e autoria da obra, exceto a assinatura da editora, estão claramente no plano da capa e em sua parte superior, a que em nossa cultura se atribui maior importância e onde se deve localizar o que é permanente e ideal. A imagem do real, que traduz e concretiza o ideal nos nossos termos, ocupa todo o fundo da capa, mas seu motivo está concentrado nos dois terços inferiores do campo da capa. É uma imagem fotográfica com valores de superfície, textura, volume e efeito "realista" da incidência de luz evidenciados. A inclinação do eixo desse motivo, também constituído de letras, junto com a sua pertinência ao plano da fotografia, e não ao dos demais textos da capa, garante o contraste entre os dois espaços com os respectivos significados e a não confusão de formas entre eles.

A ideia de progressão é semelhante à da obra analisada anteriormente, mas o recurso é outro, com o efeito sendo na verdade a estrela da capa. À semelhança da capa do Gramática em 44 lições, as letras são gravadas numa chapa de clichê tipográfico por processo fotoquímico. A letra destacada é recortada na chapa e recebe uma iluminação por trás e o efeito de incidência da luz é resultado de controle de abertura do diafragma e velocidade do obturador. Este efeito é aceito como altamente real mas de fato não ocorreria na percepção normal pelo olho; é resultado de artifícios da linguagem da fotografia transformados em códigos aceitos socialmente como realidade e altamente valorizados na época, por conotarem a ideia de alta tecnologia. São o realismo da representação, capaz de mostrar o material em detalhes mínimos, e o efeito da luz que produzem esse sentido hightech tão em voga. Aqui vemos como a linguagem dessas capas expressam uma visualidade não circunscrita ao livro escolar que o integra aos demais meios de comunicação. 

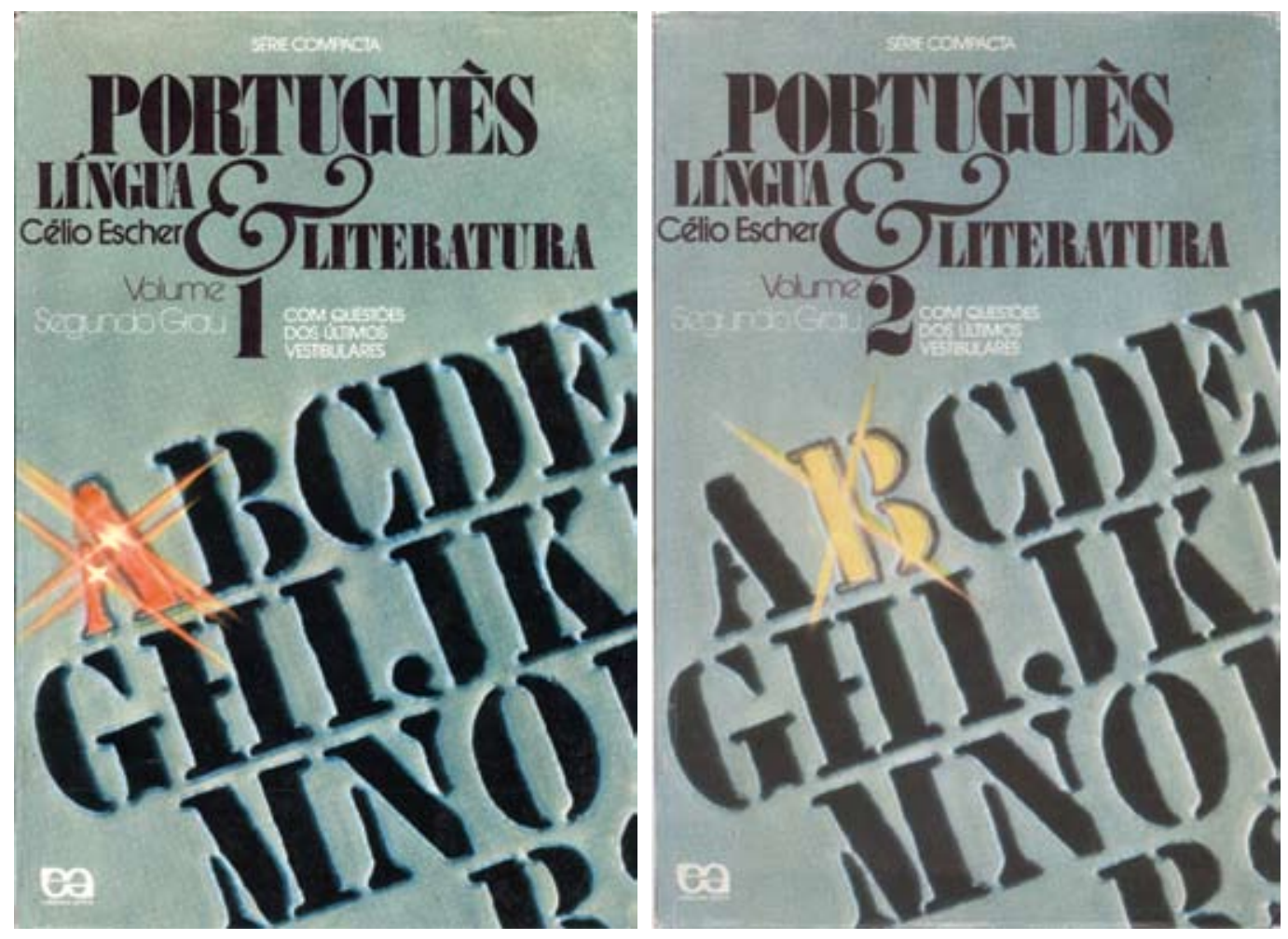

Português: Língua \&

Literatura. 2. ed., 1979.

Design Ary Normanha e Mário Cafiero.

Fotografia Delfim

Fujiwara.

$(21,7 \times 14,7 \mathrm{~cm}$; com orelhas.)
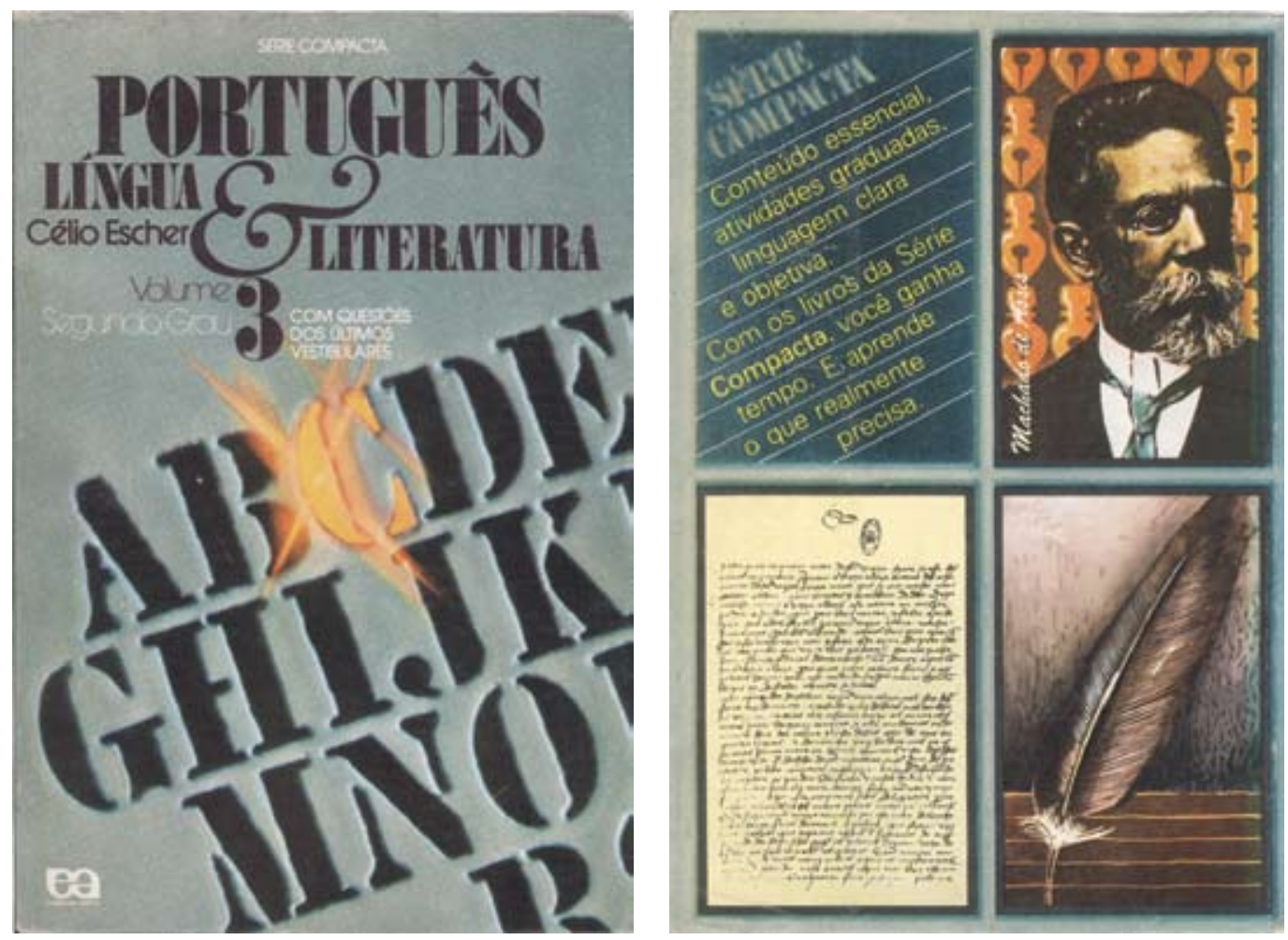

Português: Língua \& Literatura. Quarta capa. Ilustrações Paulo César Pereira e Mário Cafiero. 

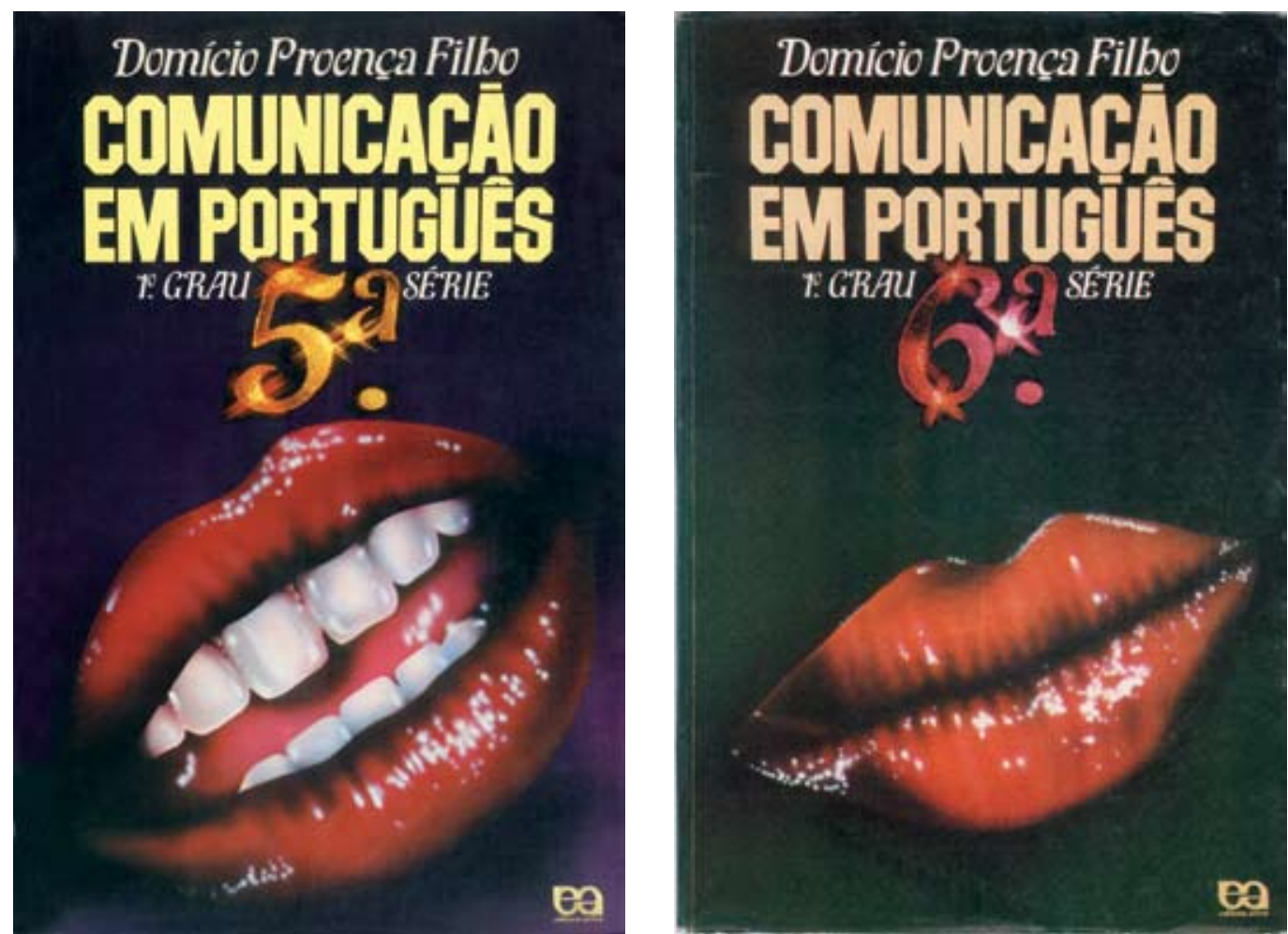

\section{Comunicação em Português - Domício Proença Filho}

Desse conjunto inicial de capas realizadas por Ary Normanha, as desta coleção parecem ser as mais capazes de atingir o público a que se dirigem. A representação ultra-realista das bocas, em cores saturadas, em que o brilho úmido e a carnalidade dos lábios são acentuados, em contraste com o volume e o branco dos dentes, é de extrema sensorialidade. Não por ser exatamente realista, porque na verdade os efeitos utilizados na ilustração e o preciosismo na representação dos detalhes criam bocas, com seus dentes e língua que exacerbam e ultrapassam o realismo da fotografia, tornando-as na verdade mais que reais, portanto, irreais.

A frontalidade e a grande dimensão produzem o sentido de oferecimento da imagem, de apelo dirigido diretamente ao visualizador, que não é um participante ou observador distante vendo algo dentro de um quadro, mas vendo algo que quase salta para o seu mundo.

A irrealidade da boca, que não pertence a nenhum rosto, fica ainda mais acentuada pelo fundo escuro, em que uma área de luz cria a espacialidade de um lugar indefinido. O aspecto conceitual da imagem, não contextual, fica estabelecido. As bocas estão pronunciando algo, estão exercendo a comunicação com o leitor, que corresponde ao conteúdo da disciplina e dos livros em questão, também expresso no título. Talvez não fique evidente num primeiro momento o que as bocas estão dizendo, o que acaba sendo um convite à imaginação e à autoexperimentação, o que dá um caráter lúdico às capas. A precisão do desenho, feito em cima de fotografia, garante a decifração, e a emissão das quatro letras iniciais do alfabeto são reconhecidas pela forma que impõe ao aparelho fonador segundo se aprende num dos conteúdos da disciplina, a fonologia. 

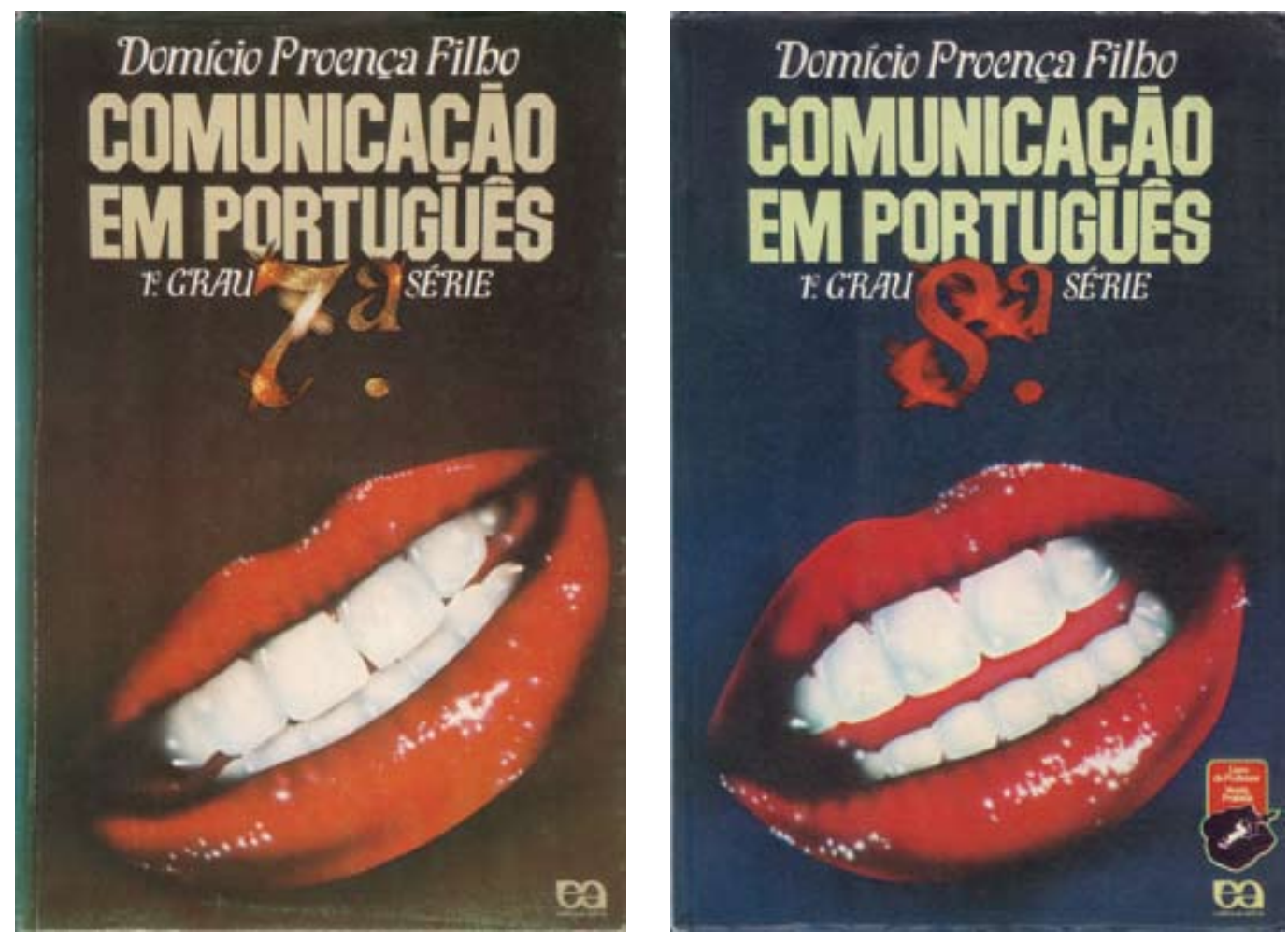

Comunicação em Português. Domício Proença Filho. 1. ed., 1979. Design Ary Normanha e Mário Cafiero. Ilustração Wanduir Durant. Fotografia Delfim Fujiwara. $(21,7 \times 14,7$ $\mathrm{cm}$; com orelhas.)

A composição geral das capas é bastante econômica e garante uma apreensão imediata e direta. O conjunto de informações textuais forma um dos blocos, com bastante destaque para o título, que organiza as outras informações em torno de si. A fonte utilizada no título (Machine) forma um desenho bastante coeso e que equilibra a imagem da parte inferior do campo. O número da série, por sua dimensão, posição e tratamento "realista" de brilho metálico que o aproximam da linguagem da ilustração, conecta os bois blocos numa imagem coesa e estruturada, além de garantir a identificação dos volumes. A inclinação das bocas, a par de prencher o campo e dar maior força para a imagem, garante dinamismo e movimento que uma boca no eixo vertical, menor e mais tímida, não propiciaria.

O efeito hiperrealista mencionado é obtido pela técnica de ilustração, a aerografia, usando uma referência fotográfica. O aerógrafo permite o borrifamento ultra-controlado de quantidades mínimas de tinta sobre o papel e a representação de volumes e luzes e contornos esmaecidos e fluidos, mais próximos de como percebemos os objetos e de como a fotografia os capta. Mas a possibilidade desse controle e o uso de tipos diferentes de tintas permite também o exacerbamento dos efeitos que caracterizará a própria linguagem desse instrumento, com a criação de um mundo mais real que o real, o que talvez explique o fascínio que exercia e sua forte presença na publicidade, ilustração e história em quadrinhos nessas décadas.

Estas capas foram agrupadas entre outras caracterizadas como montagens fotográficas não pela primeira capa, mas pela quarta capa, à qual se atribui grande importância e na qual se investe trabalho equivalente ao da primeira capa. Assim, a quarta capa apresenta a fotografia de uma caixa com uma coleção de objetos 
Comunicação em Português. Quarta capa.

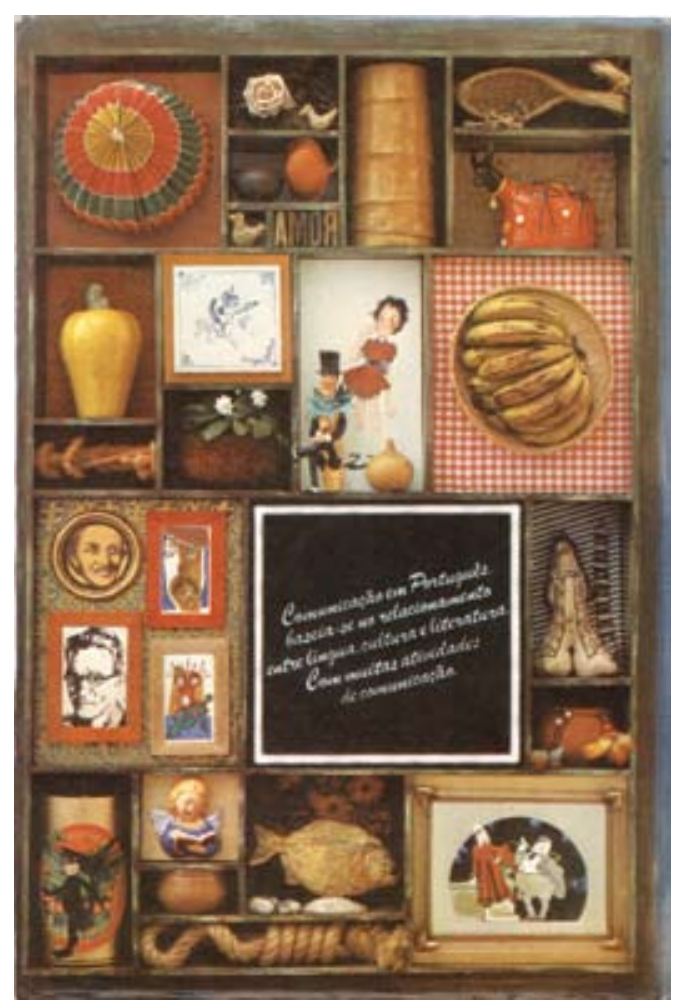

tridimensionais, conforme descrito na seção anterior, e que será melhor explorada na análise da próxima capa. Fazendo alusão a conteúdos dos textos literários apresentados na obra, os objetos são um convite a conhecer estes textos e a um jogo que pode durar o tempo de uso da coleção, com descobertas que podem acontecer a qualquer momento. . 

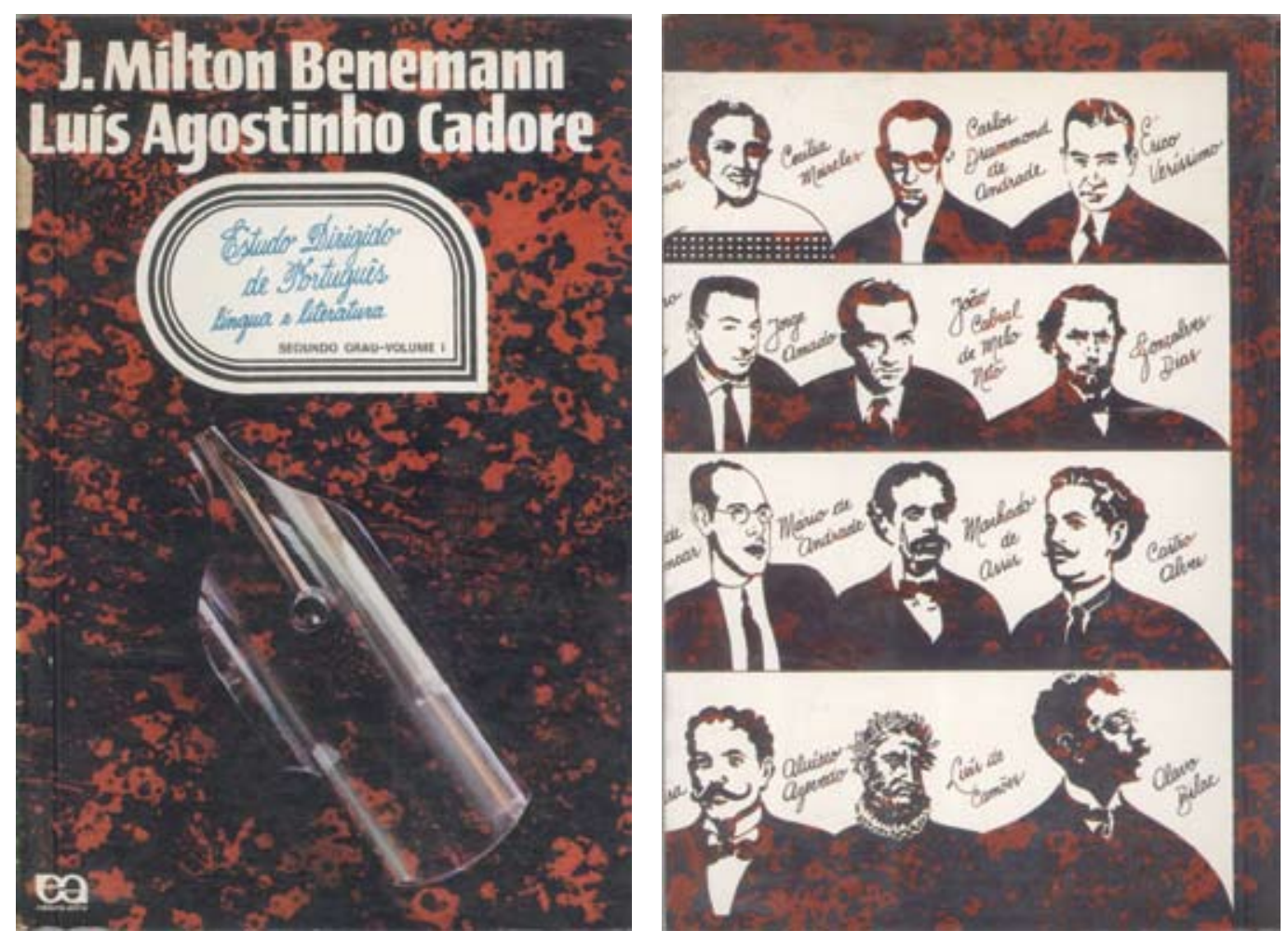

Estudo dirigido de Português. J. Milton Benemann e Luís A. Cadore.1. ed., 1979. Design Mário Cafiero. Objeto Walter Durant. Fotografia Delfim Fujiwara e Sérgio Tegon. $(20,7 \times 13,7$ cm; plastificada, com orelhas.)

Capa e quarta capa.

\section{Estudo dirigido de Português - Benemann e Cadore}

Projetada e executada por Mário Cafiero, esta capa também busca o efeito de fotografia realista que capte as características físicas dos materiais, no caso, a transparência e reflexos da pena de acrílico sobre uma superfície de aparência orgânica. A precisão do desenho da sólida mas também leve peça de acrílico contrasta com a textura de desenho aleatório de forte tonalidade misturada com preto. Na verdade este desenho foi obtido pela repulsão entre a tinta e um produto betuminoso sobre o vidro e o objetivo é o puro efeito visual, com a conotação de realismo e tecnologia, pois o acrílico era um material recente e "na moda". A pena de caneta de tinta, já não mais em uso, é eternizada num material nobre, valorizado e moderno, representando os valores perpétuos da escrita e da literatura. O acrílico assume o papel que em outras épocas seria atribuído ao cristal, com o sentido acrescido de tecnologia e modernidade.

Ocupando mais da metade inferior da capa e com grande dimensão, o que permite carregar o simbolismo mencionado, a pena é equilibrada com a massa de texto do nome dos autores na parte superior. O título da obra aparece manuscrito em tinta azul, como escrito por uma pena, numa prosaica etiqueta como as que se costumava colar em livros e cadernos e que aqui parece colada no próprio livro. Assim, a pena estaria sobre a própria superfície do livro.

A quarta capa apresenta uma galeria de autores da literatura brasileira e portuguesa, em desenho de traço e superfícies recortadas que revelam o fundo texturado e com os nomes também manuscritos. Não há hierarquia entre eles, pois a composição é simétrica e eles estão no mesmo plano, descontextualizado e objetivo, o que conota atemporalidade e que todos são representantes da cultura literária, matriz simbolizada pela pena da primeira capa. 

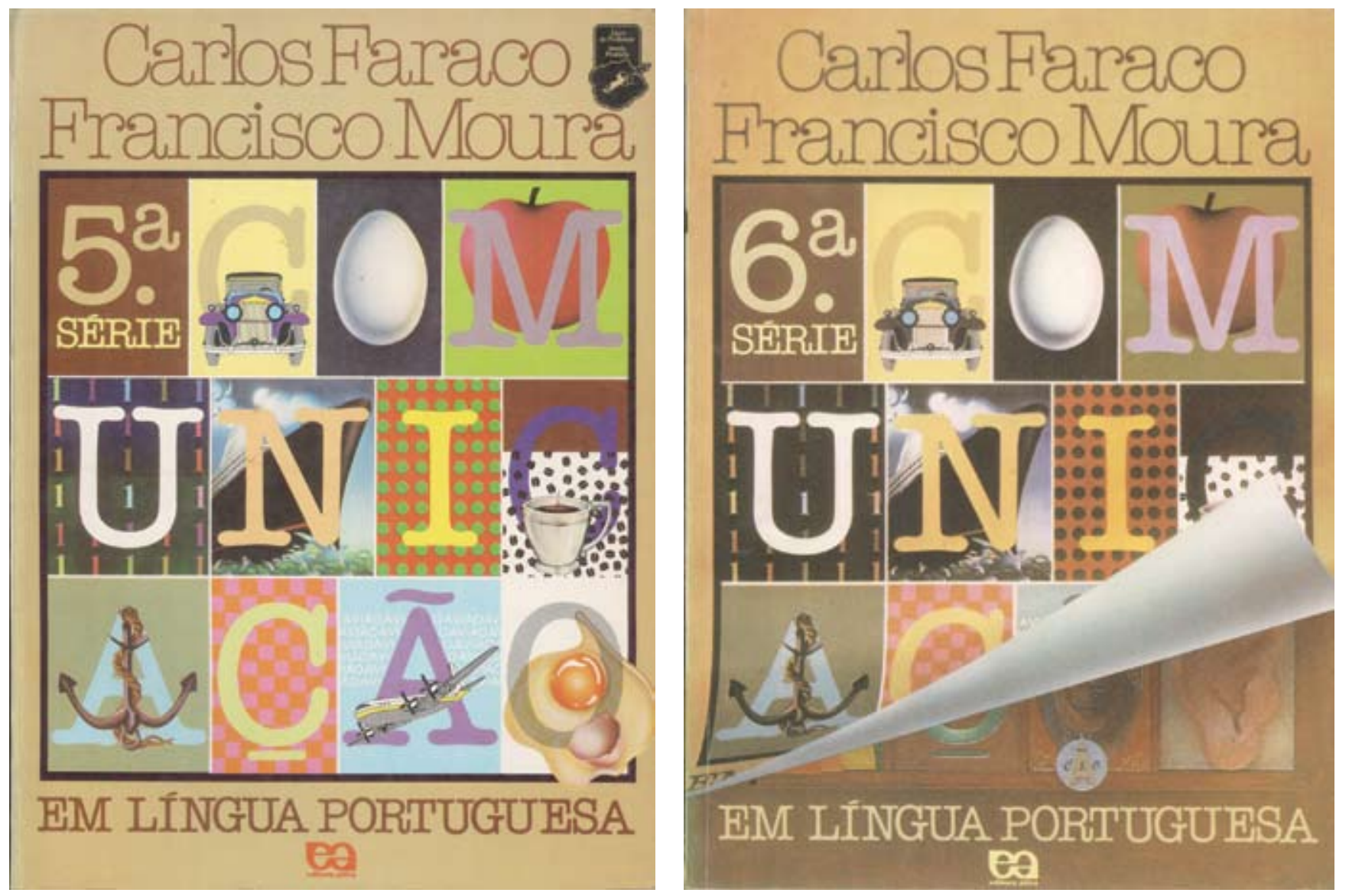

\section{Comunicação em Língua Portuguesa - Faraco e Moura}

Produzida em 1979 e lançada em 1980, esta coleção alcançará grande sucesso durante toda a década e é uma das primeiras que trazem essa nova linguagem das montagens fotográficas que caracterizará muitas das capas da editora, com uma particularidade: ela não está presente em todos os volumes da coleção, mas é apresentada aos poucos.

Vendo as capas juntas, o que talvez chame primeiro a atenção seja a estrutura formal praticamente igual, mas em que se percebem diferenças de um volume para outro. Num segundo momento talvez se tente buscar o que sejam essas diferenças e os nexos entre elas e, assim, se descubra a narrativa visual existente da 5. à 8. ${ }^{\text {a }}$ série.

Mas se o conjunto em si é bastante rico e chamativo, chega o momento em

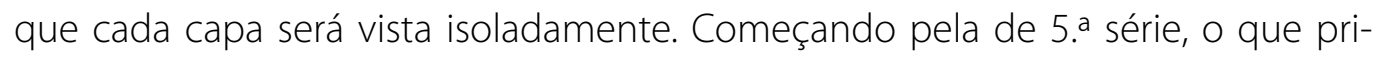
meiro chama a atenção é a grande ilustração quadrada central, na verdade um retângulo, percebido dessa forma devido às relações com o retângulo maior do campo da capa. Nela se percebem várias áreas retangulares menores com figuras e grandes letras coloridas em contraste com um fundo beje claro da área maior, definida pelo formato do livro. Numa apreensão ainda quase imediata e totalizante se reconhecem nomes e palavras nesse fundo, em marrom escuro, circundando o quadrado colorido.

Parece que só num momento seguinte a figura central, mais complexa, vai ser 

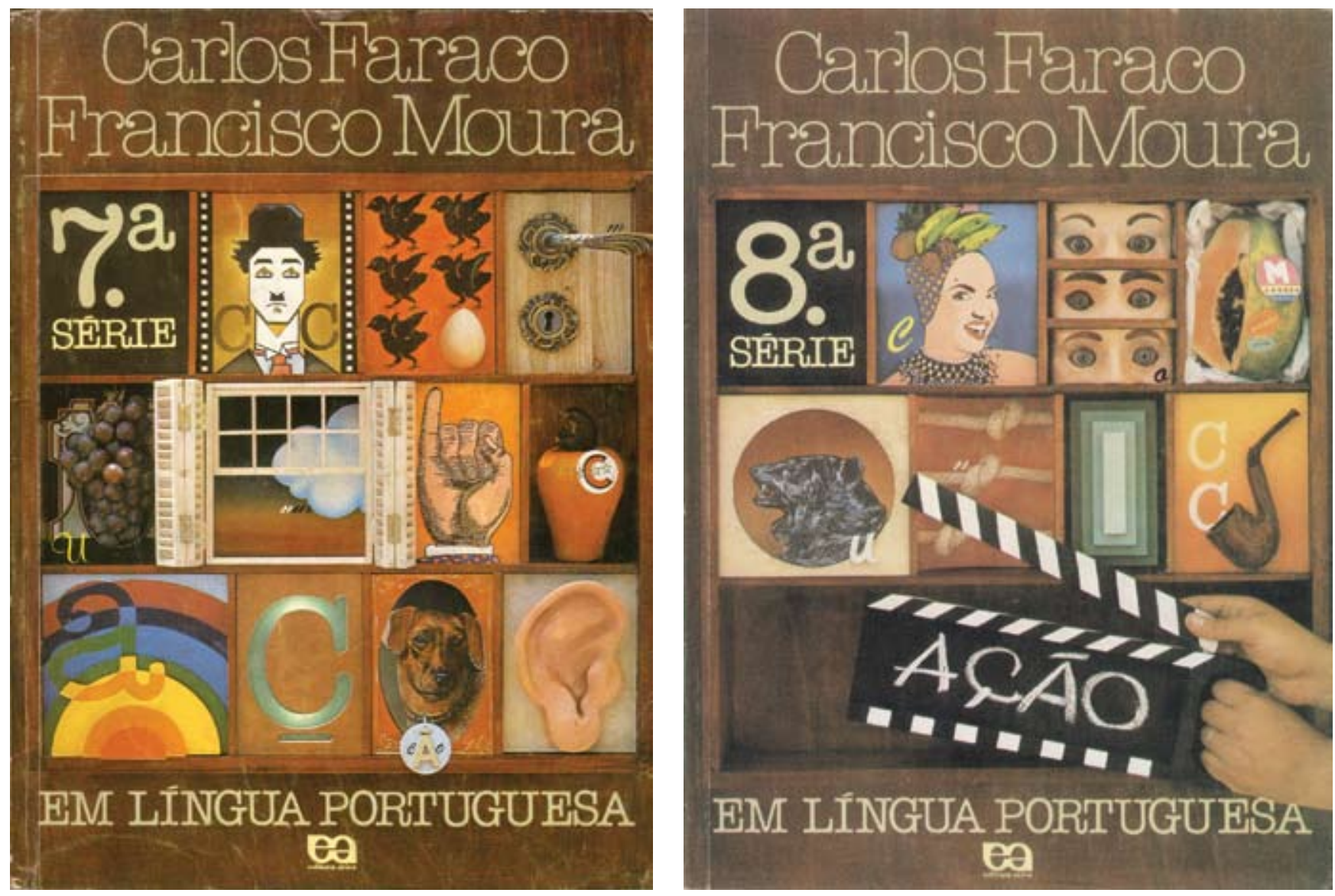

desvendada. Mesmo com o olho sendo atraído para vários focos aleatoriamente ou de maneira impossível de prever, pelos contrastes ou interesses despertados pelo inusitado de figuras e tratamentos gráficos, as grandes letras impõem a leitura de uma palavra, que conduz à sua complementação nas palavras que a seguem localizadas na parte inferior do quadrado revelando o título da obra. Também é lida de maneira evidente a informação de série localizada na primeira subdivisão ao alto, na esquerda.

Assim, a identificação da obra é feita sem grande dificuldade mas de maneira bastante interessante e surpreendente porque não se apoia na usual leitura de um texto composto unicamente por letras. E as complexidades das subdivisões do quadrado, com suas figuras e letras coloridas continuam atraindo os olhos para serem desvendadas e apreciadas. Talvez já se tenha percebido a relação entre as letras e os objetos representados como suas iniciais, à maneira das cartilhas com Comunicação em Língua Portuguesa. Faraco e Moura. 1. ed., 1979. Design Ary Normanha e Mário Cafiero. llustrações e objetos René E. Ardanuy, Wanduir Durant, Mário Cafiero, Paulo César Pereira, Alcides Batista e Patrícia Feixas. Quarta capa Mário Cafiero e Lázaro Mendonça (marcenaria). Fotos Delfim Fujiwara. $(27,4 \times 20,2 \mathrm{~cm})$ que se alfabetizava e ainda se alfabetiza hoje, porque nosso cérebro decodifica os estímulos sensoriais holisticamente e sem seguir uma ordem lógica..

Esta descrição linguística do provável percurso da vista, reconhecimento do material e construção dos significados talvez acabe encobrindo o que se quer mostrar: a imediaticidade da comunicação de alguns significados presentes nesse design. O primeiro deles é o prazer estético, o gostar da imagem que se tem diante dos olhos, o querer continuar a vê-la para proceder à descoberta de outros significados e também prazeres. 
${ }^{10}$ As fontes de inspiração e recursos de linguagem desse design alinham-se com o design-ilustração, já mencionado: presença marcante da ilustração, uso expressivo da tipografia e caligrafia, referência à arte comercial e seu repertório de imagens, linguagem da pop art norte-americana, uso de ícones da cultura visual brasileira, mescla de fotografia, ilustração e letras lembrando as colagens surrealistas ou dadaístas e até a estrutura ortogonal do design modernista. A imaginação e 0 humor presentes nessas capas e a não preocupação com legibilidade as afastam do design modernista. Por exemplo, já no próprio título, 0 que chama a atenção é que a "comunicação" nele presente não se dá pela "legibilidade acima de tudo" da tipografia funcional ou a clareza do estilo internacional dos anos 1950 e 1960.

11 Como esse é um dos conteúdos explicitados em lições do livro, correspondendo à entrada no ensino fundamental das teorias da informação e da linguística desenvolvidas na academia desde a década de 1960 — que destacavam a língua como intrumento de comunicação com as noções de código, repertório, emissor e emitente - essa é uma possibilidade aberta.
Mas não parece ser o reconhecimento e a identificação dos objetos representados que motivam em primeiro lugar maior ou menor adesão emotiva do visualizador, e, sim, a composição como um todo, seu jogo de formas e multicolorido, e talvez a alusão geral que ela faça ao universo do lúdico vivido pelos pré-adolescentes, com a presença dos álbuns de figurinhas e das histórias em quadrinhos. É claro que aí pode entrar a identificação com um ou outro objeto valorizado pela cultura juvenil da época, mas parece que o sentido geral de jogo, dado não só pela relação dos objetos com suas iniciais, mas pela construção de uma sequência pela justaposição de elementos individuais, parece predominar.

Essa ludicidade é comunicada também pela sensação de aleatoriedade e liberdade que a mistura de formas e cores propicia, efeito de sentido necessário à ideia de jogo. E é ampliada pelo convite ao jogo de examinar cada uma das figurinhas e descobrir como ela se encaixa no jogo geral de montagem da palavra. Por haver uma regra geral reconhecida - a identidade entre inicial do nome e o objeto as exceções a ela, os acidentes, vão oferecer interesse redobrado. Assim, uma das letras é simplesmente substituída pelo objeto com que se assemelha diretamente; outra é a inicial de um algarismo, que, apesar de representar a unidade, aparece repetido formando uma textura colorida; outro não pode ser a inicial porque não existe palavra com sinal gráfico nessa condição; outras não estão associadas a objetos mas apenas a formas e texturas; numa delas, o objeto aparece em duas condições, e aí estravasa o espaço a ele determinado. A ludicidade é ainda reforçada pela diversidade de linguagens de ilustração, indo das figuras prontas feitas a traço preto e preenchidas por cor, encontradas nos álbuns de figurinha, até o hiper-realismo estilizado da pop art, e indo dos fundos chapados ao uso de texturas, em contrastes de cores encontrados no design psicodélico bastante próximo à época. ${ }^{\mathbf{1 0}}$

Totalmente ligado a essa forma geral e a esse sentido de ludicidade ocorre outro significado importante e decisivo, o sentido da palavra comunicação. Em vez de ser escrita linguisticamente, pela sequência de letras, ela é transmitida por uma imagem, ou por uma relação texto-imagem, que dá o sentido de multimodalidade ao termo. Não se trata mais só da comunicação pelos meios e modo da linguagem verbal escrita, mas sobretudo pelo modo visual. Isso é bastante significativo na época, pois a presença cada vez maior dos meios de comunicação de massas, em que a imagem ganha predominância em relação ao texto, impõe essa nova realidade, vivida plenamente pelos jovens - mas não incorporada pela cultura escolar —, que o design dessa capa expressa, valoriza e explora.

Mas há outro significado básico que está ao alcance dos alunos. Se na correspondência que ele encontra entre letras e objetos à maneira das cartilhas com que se alfabetizou há a recuperação de um procedimento já conhecido, ele ocorre num novo contexto, de maior maturidade e conhecimento. Assim, ao lado de um aspecto paródico e divertido que essa recuperação evoca, talvez esse diálogo entre signos de linguagens diferentes permita agora ao estudante de 11 anos, ou mais velho nos anos seguintes, perceber justamente o caráter de signo de letras, palavras e imagens e de seu uso articulado em linguagens para a representação de coisas e ideias. ${ }^{11}$ 
Um elemento importante que contribui para esses significados é o próprio desenho da fonte utilizada, o American Typewriter, que, como o nome diz, é inspirado nos tipos de máquinas de escrever, dispositivo de produção de textos generalizado no período, reconhecível por todos dados seu uso e presença em todas as situações de elaboração de originais, documentos e até trabalhos escolares. ${ }^{\mathbf{2}}$

Se, como já vimos e vamos retomar adiante, existe uma narração visual entre as várias capas, ela não existe em cada capa isoladamente. A única sequência que poderia induzir a uma ideia de narração seria a das letras formando a palavra do título, mas ela é totalmente truncada pela presença mais forte dos objetos e formas, que atraem o olhar de modo aleatório e não ordenado linearmente - e nem por isso impedem de apreender o conteúdo linguístico. Assim, se há uma forma geral que até alude à forma das histórias em quadrinhos, de fato nenhuma relação temporal de causa e efeito é estabelecida pela sequência dos espaços-objetos representados, talvez com exceção da brincadeira do ovo. Trata-se na verdade de uma coleção em que todos têm importância igual e sua reunião só não é completamente aleatória porque se relacionam de alguma forma com as letras do título, embora outros objetos pudessem ter sido escolhidos. Mas diferentemente de uma coleção temática, de borboletas ou pedras, é uma coleção mais ampla, totalmente aberta, uma coleção em que tudo cabe, porque as linguagens servem para representar o mundo e tudo o que ele contém.

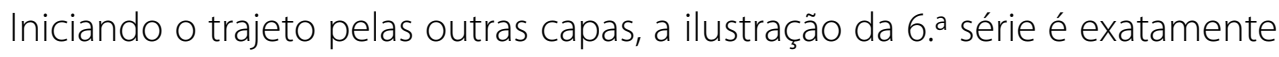
a de 5. a ,com uma diferença de tonalidade para individualizar o volume, sofrendo o efeito de um descolamento, num efeito hiper-realista de tridimensionalidade muito bem executado e de grande poder de sedução ${ }^{\mathbf{1 3}}$, que revela alguma outra coisa por baixo, parte do que parece ser uma caixa de madeira com alguns objetos tridimensionais.

Aquilo de que se mostra apenas um pedaço é exatamente parte da capa da 7. a série, agora totalmente revelada, que tem como elemento central uma caixa de madeira fotografada, tridimensional, com subdivisões preenchidas com objetos também tridimensionais, ampliando a coleção e a variedade de linguagens. Note-se que as letras do título praticamente sumiram, aparecem apenas como pequenos índices para tirar qualquer dúvida de um título que já não é mais explícito. O jogo que se antevia na primeira capa é totalmente assumido como tal: o título precisa ser decodificado, como nas cartas enigmáticas. A coleção de figurinhas vira uma coleção de objetos na sua caixa de guardar. Não é preciso lembrar que colecionar é uma prática comum entre pré-adolescentes, pelos menos nessa época.

A justaposição desses objetos, alguns desenhos em linguagens de outras épocas, minicenários ou objetos únicos, partes do corpo humano, formam um conjunto em que predomina o inusitado, o nonsense, a fantasia, com forte carga poética. Se há aqui uma referência explícita à arte dadá e ao surrealismo, fontes eruditas em que o designer bebeu e que os alunos podem desconhecer, o que importa é que eles podem fruir a capa como fantasia, poesia visual, de que essa capa é pura expressão, e ter acesso à ideia da função poética que a linguagem, visual ou verbal, pode construir.
12 Sua presença alude à ideia de produção de texto escrito por excelência, funcionando como um índice desse sentido. Por isso talvez que, em muitos catálogos de tipos da época, era encontrado na seção de tipos fantasia, por não ser destinado à composição tipográfica de textos para leitura, mas para títulos, mensagens publicitárias e outras em que a forma deve fazer alusões como as mencionadas.

13 É claro que 0 visualizador percebe que se trata de um desenho bidimensional, mas parece que há uma grande satisfaçãa em se sentir quase enganado pela maestria da execução, como o que ocorria com as perspectivas pintadas em igrejas barrocas, que reproduziam elementos e parte do espaço arquitetônico ampliando-0, o que, mesmo não enganando completamente 0 observador, jogava com esse interesse. 
Um significado que esse percurso do bi para o tridimensional, da ilustração para a fotografia, da "fantasia" para a "realidade" pode carregar é o do reconhecimento do crescimento intelectual do estudante, o que repercutiria favoravelmente na recepção às capas. Há uma complexização das ideias e das formas e um chamado a um engajamento perceptivo maior do aluno, bem como uma provocação à curiosidade em saber qual será a novidade da próxima série. Nesse sentido a última capa é exemplar. Mesmo sem uma promessa explícita de surpresa final, esta ocorre: a estrutura visual é parcialmente quebrada e no lugar dos compartimentos inferiores da caixa, um par de mãos reais, não modeladas, acionam uma claquete posta à frente da caixa, acentuando ainda mais a tridimensionalidade e efetivamente representando o sentido da palavra nela escrita — ação. Essa ação aparece como que culminando a sucessão de mudanças e revelações anteriores e termina com um convite ao jovem leitor a se comunicar, a usar a linguagem e participar.

Nessas capas não há a preocupação de traduzir ou expressar conteúdos disciplinares específicos, seja da disciplina geral, seja dos volumes. Exceto pelo uso de imagens alusivas genericamente a cartilhas e, portanto, ao ensino da língua, o significado básico comum a todas as capas diz respeito a um fenômeno e um processo social de alcance mais amplo e que extrapola, ou melhor, abarca a disciplina em questão, que é o da comunicação e da cultura. O repertório de objetos não expressa temas da disciplina ou do universo de interesses mais imediato do público, mas coisas do mundo e da cultura em geral e do país. E o prazer estético que os arranjos das várias capas propiciam é um objetivo sempre reafirmado pelo designer.

Assim é que a quarta capa apresenta a fotografia de uma caixa de luz com

Comunicação em Língua Portuguesa. Quarta capa.

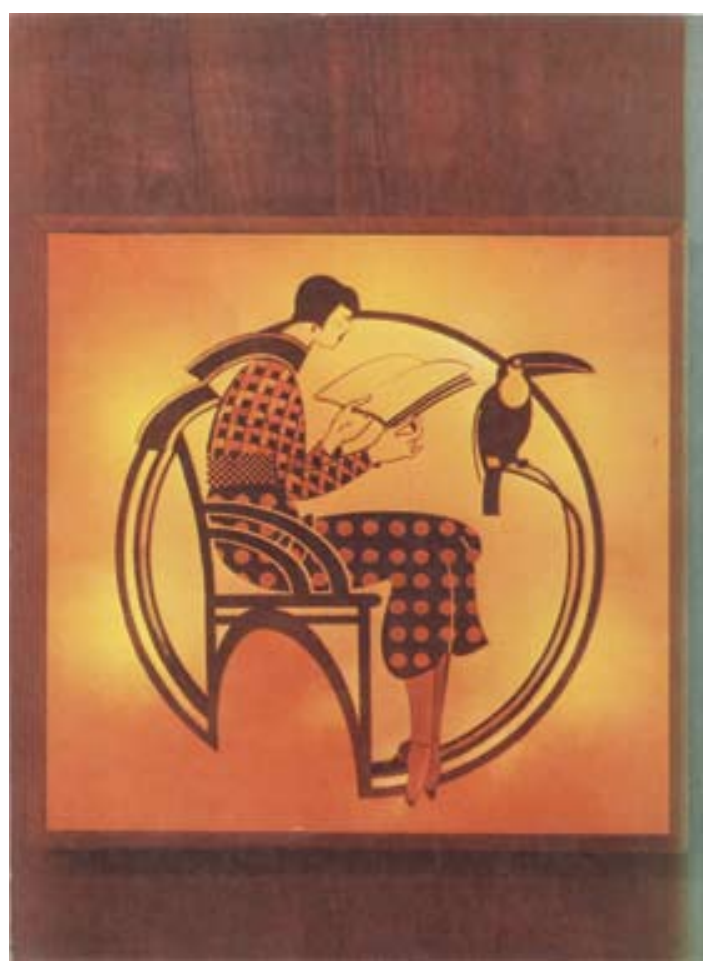
uma delicadíssima ilustração em estilo art-nouveau. Feita por Mário Cafiero, ela tem como referência e é uma homenagem ao grande ilustrador e artista gráfico brasileiro J. Carlos, atuante dos anos 1910 aos 1940. Pensada como uma homenagem às professoras, enquanto na primeira capa são vários os objetos representados, aqui essa imagem reina absoluta, o que talvez dê a ela um caráter de síntese dos significados da capa e do livro, além do mencionado interesse em veicular beleza em si. A sofisticação e elegância do desenho, propiciando prazer estético, associam este ao ato de leitura representado. A informação propiciada sobre uma linguagem, uma época, um artista brasileiro e a referência à brasilidade, com sabor tropicalista, completam o sentido de valorização da cultura em geral e da cultura brasileira em particular.

As lombadas também merecem atenção, e no caso desta coleção é a fotografia de clichê tipográfico como os utilizados nas capas anteriores. Há assim, uma justaposição de técnicas e linguagens distribuídas entre as primeiras e quartas capas e lombadas, como a ideia de colagem, e não a extensão de uma mesma solução unindo-as formalmente, como seria a reposta do design estritamente modernista 


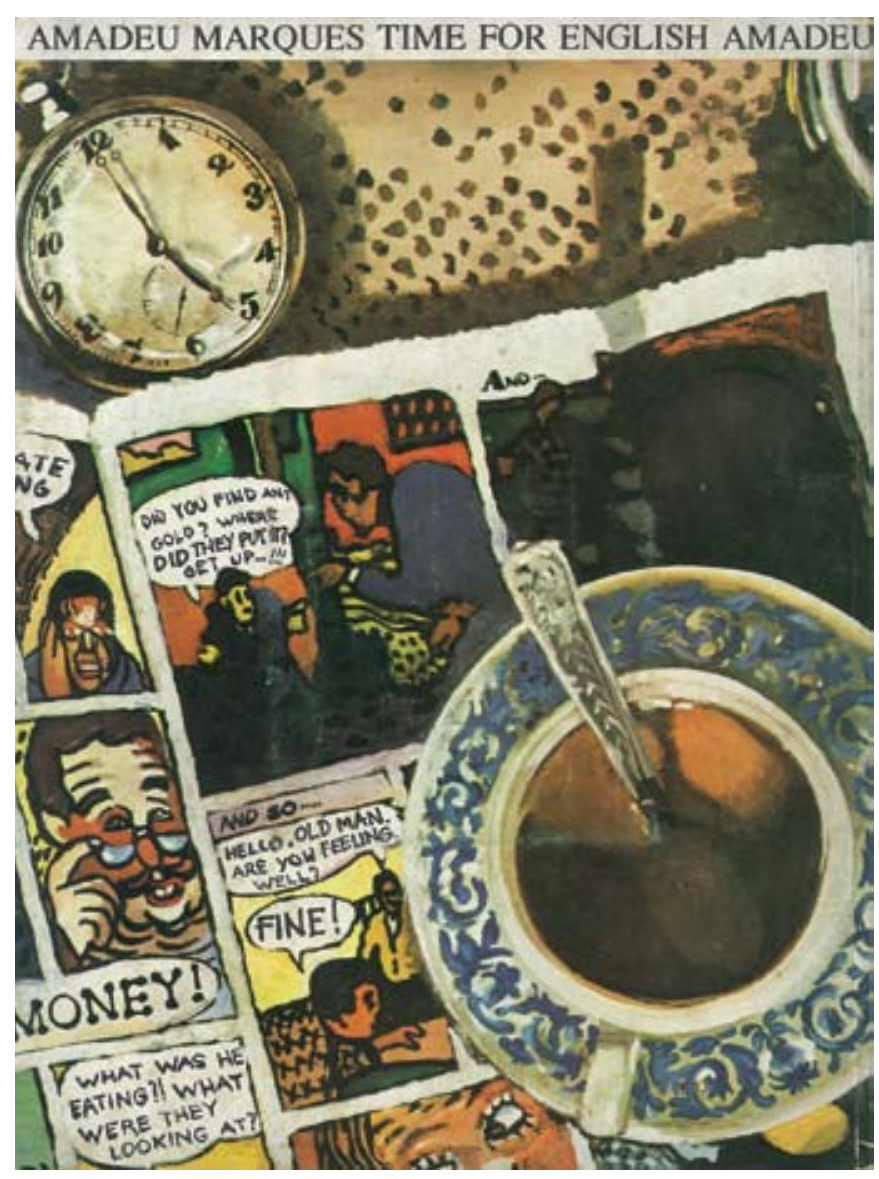

\section{Time for English - Amadeu Marques}

As quatro capas da coleção apresentam imagens muito particulares e diferenciadas. Em todas elas, as informações textuais — título, autor e volume - estão incorporadas à imagem e à linguagem utilizada, e este na verdade é o princípio comum, a ideia geradora do design que as une, ao mesmo tempo que possibilita a grande variedade de linguagens e o interesse que essa variedade pode propiciar.

A faixa superior com os nomes do autor e da obra funciona como elemento gráfico de identificação da coleção, em que cada volume tem a sua proposta ilustrativa própria. Essa liberdade foge da lógica sistêmica que marca a maioria das abordagens de coleção, principalmente no design de orientação modernista.

O book one é uma ilustração pintada que extravasa para a quarta capa, a qual apresenta os elementos mais interessantes (a história em quadrinhos, a xícara de chá e o relógio de bolso). Assim, a primeira capa identifica a obra, enquanto a quarta capa a complementa e é bastante valorizada.

O book two reúne a fotografia de caixa de objetos das culturas inglesa e americana com ilustração num inusitado e sofisticado cartum tridimensional. Nele, com muita ironia, a cultura de massas americana se sobrepõe às tradições britânicas: o papel de parede formado por um padrão de cachorro-quente; o título escrito com mostarda; a mostarda no chapéu coco inglês; a etiqueta do saquinho de chá; o cachorro-quente na renda; uma Elizabeth I olhando não muito feliz para o leitor. $\mathrm{Na}$ quarta capa a síntese: o cachorro-quente comido, a porção de mostarda e o guardanapo amassado na tradicional louça inglesa.
Time for English; book one. Amadeu Marques. 4. ed., 1982.

Design Ary Normanha e Mário Cafiero.

Ilustração Mário Cafiero.

$(27,5 \times 20,2 \mathrm{~cm}$.) Capa e quarta capa. 

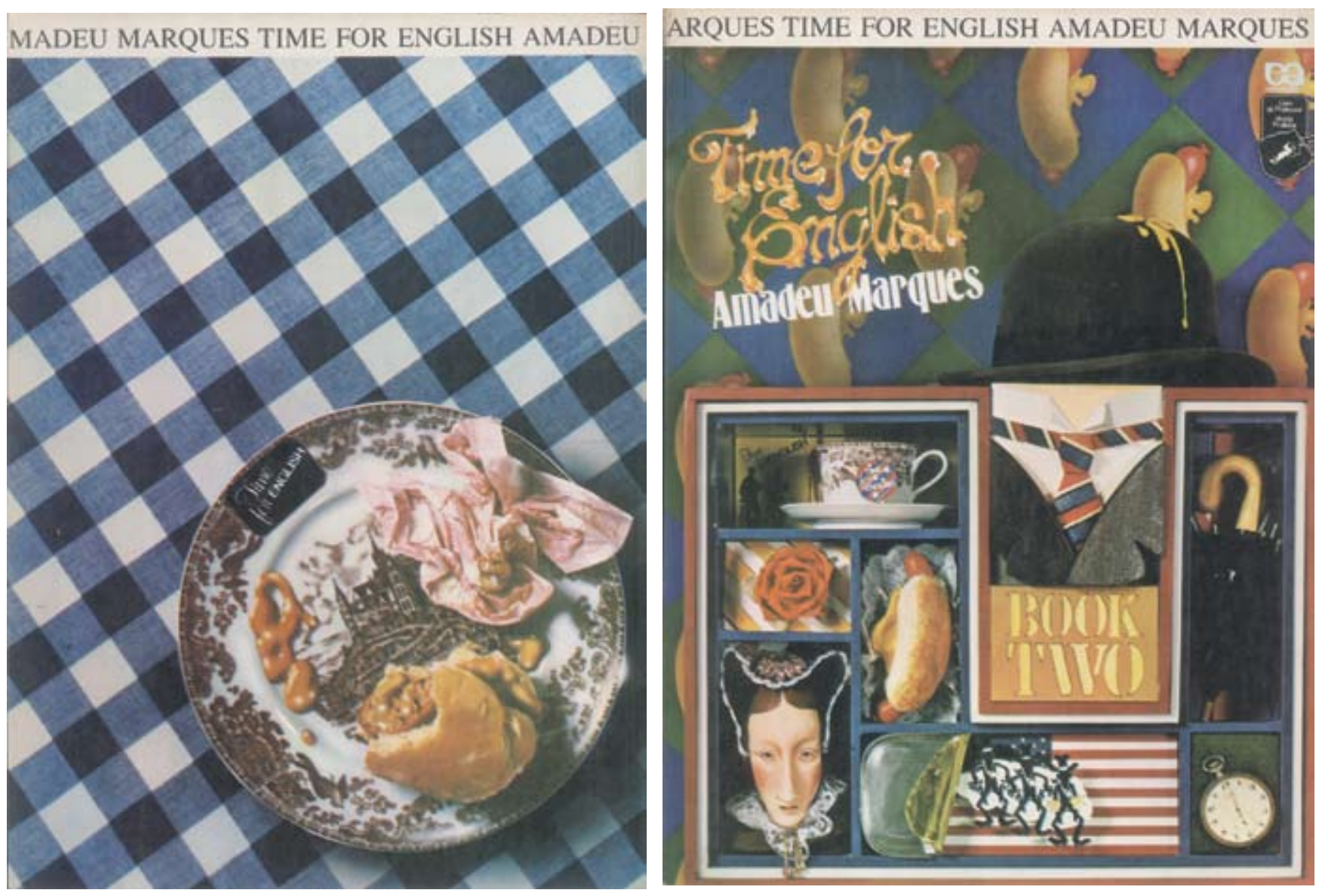

Time for English; book two. Amadeu Marques. 4. ed., 1982. Design Ary Normanha e Mário Cafiero. llustrações Mário Cafiero, Wanduir Durant, Ary Normanha, Paulo César Pereira, Aderbal Moura, Roberto Soeiro, René Ardanuy. Marcenaria Lázaro Mendonça. $(27,5 \times 20,2 \mathrm{~cm})$. Capa e quarta capa.

Time for English; book four. Amadeu Marques. 3. ed., 1982. Design Ary Normanha. Foto Sérgio Tegon. (27,5 x20,2 cm). Capa e quarta capa.
No book three, a ilustração baseada em fotografia de um jeans cheio de apliques e uma etiqueta de couro especialmente pirografada com as informações da obra garantem a identificação com o público jovem e se relacionam com a cultura de massas norte-americana. Como no primeiro volume, a imagem continua e completa-se na quarta capa, com o título bordado e o número 3 em tipo de camiseta de jogador.

O book four apresenta a fotografia de um entalhe de madeira em letras góticas, de desenho simétrico, com áreas pintadas e ocupando toda a capa, numa alusão à tradição e ao passado inglês. Na quarta capa o mesmo entalhe aparece num estágio anterior da execução, com o formão utilizado e cavacos de madeira.

Todas elas tiveram um projeto e uma produção planejada, com a execução dividida entre Ary Normanha e Mário Cafiero, tendo a caixa de objetos contado com a participação de vários colaboradores sob a direção de arte de Ary Normanha. 

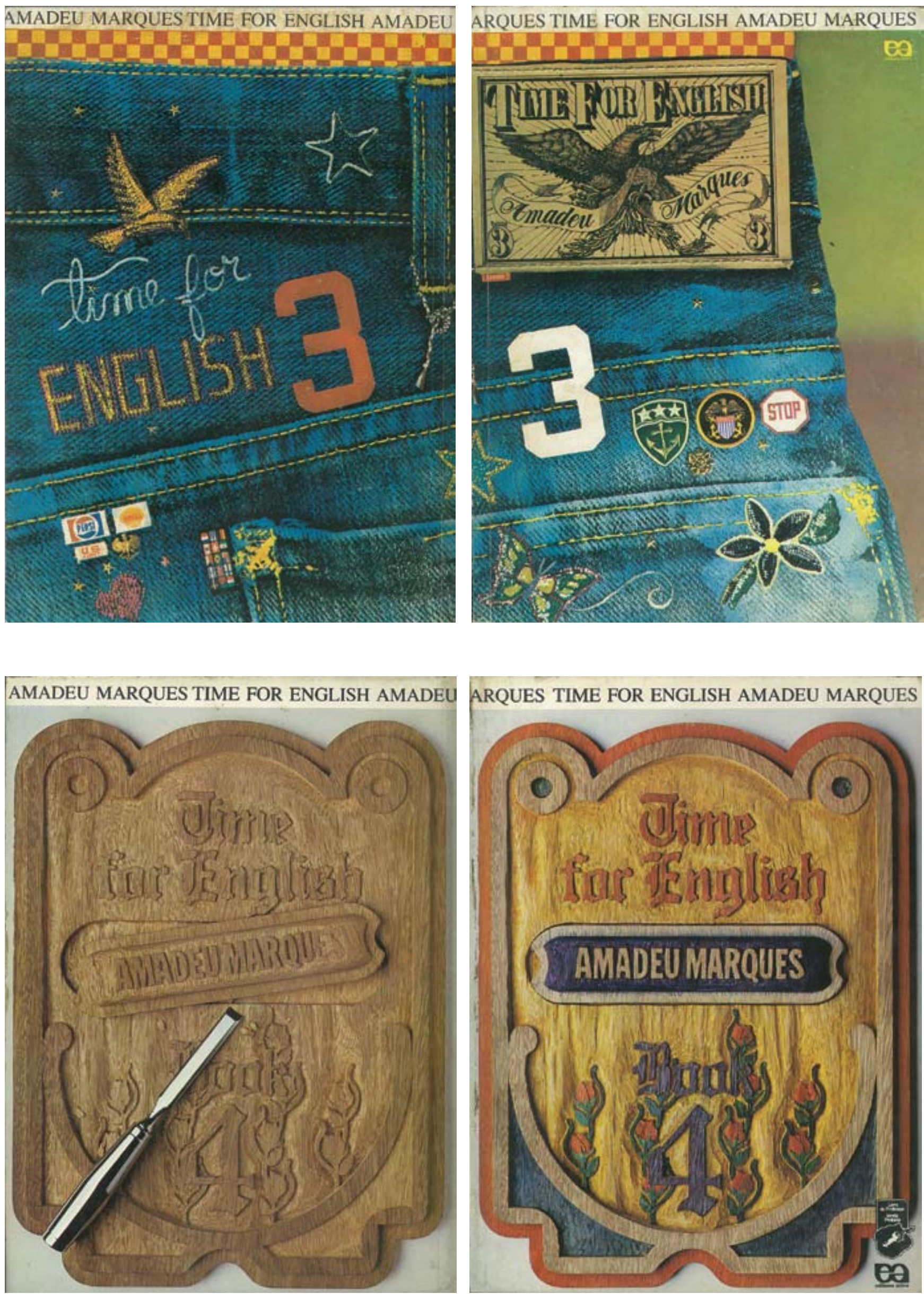

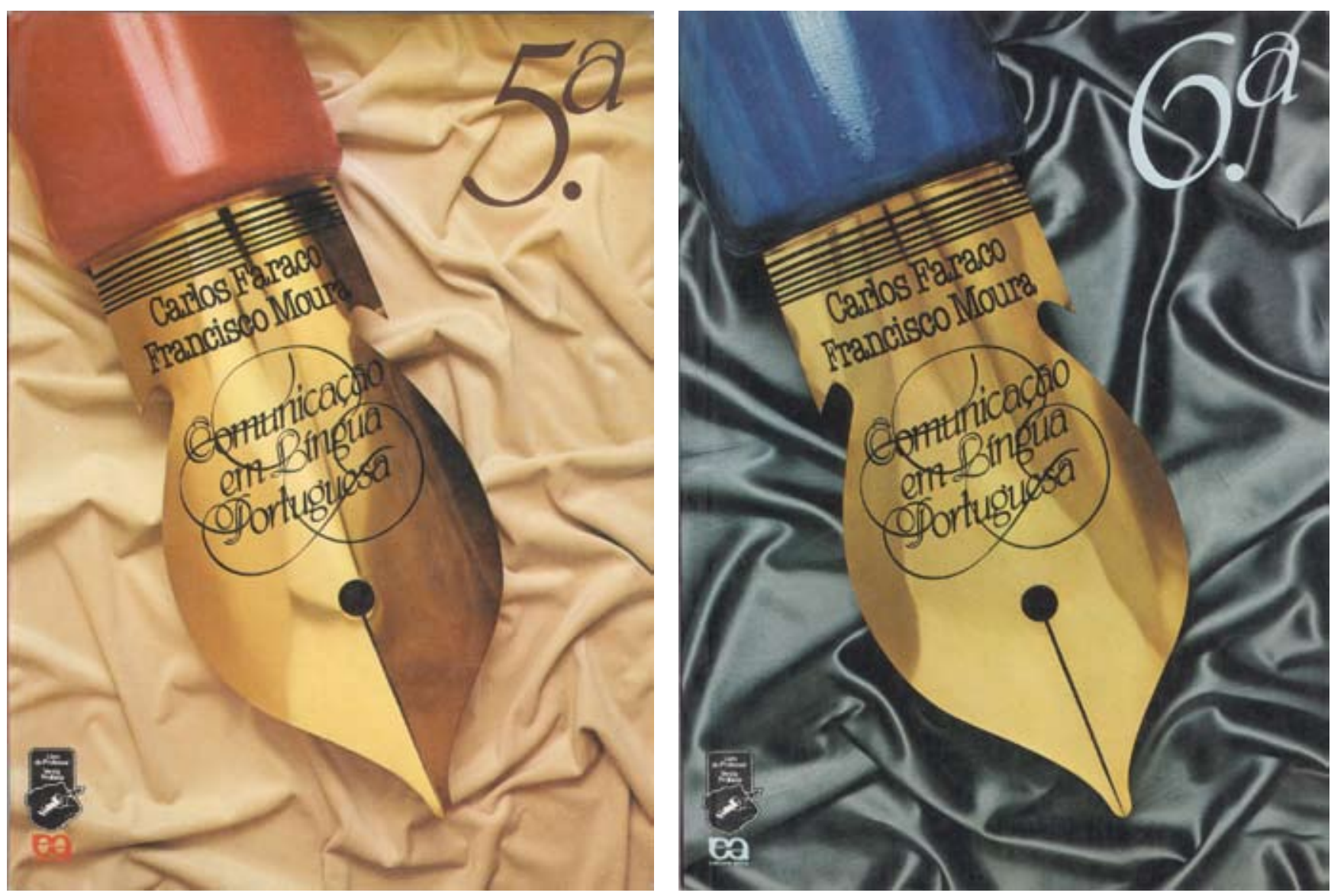

\section{Comunicação em Língua Portuguesa - Faraco e Moura}

Estas capas sucederam as da primeira edição. Nelas há a busca do efeito visual realista, a partir do uso da fotografia, com a criação de forte sensação tátil, propiciada pelo volume das dobras sinuosas do cetim, com seus reflexos e sombras. A forma curva da pena metálica dourada reflete também a incidência da luz e as dobras do cetim (embora seja provável que se trate de duas fotografias fundidas). A fotografia capta também os efeitos da iluminação no cabo laqueado da caneta. Também é simulada de maneira razoavelmente realista uma gravação do título e nome dos autores na pena, ocupando o centro da capa e dando essas informações de maneira muito direta e clara.

Não há nenhum outro objeto como referência, para vermos essa pena como simplesmente um objeto real ampliado fotograficamente. Na verdade, a sensação é de uma grande, imensa pena, ocupando quase todo o campo e impondo sua presença hiperbolicamente. Assim, junto com um sentido de materialidade vem um sentido mais transcendente, simbólico, de representação da língua e da escrita. Isso é reforçado porque efetivamente há muito não se escreve com esse instrumento, que perdeu presença na realidade cotidiana, restando as associações que ele pode carregar. Portando o título da obra, esse sentido fica ainda mais explicitado. O cetim, e principalmente a pena dourada, conotam valores atemporais, atribuindo-os aos conceitos de língua portuguesa e comunicação.

A materialidade da realização, principalmente a ideia da inscrição na pena, 

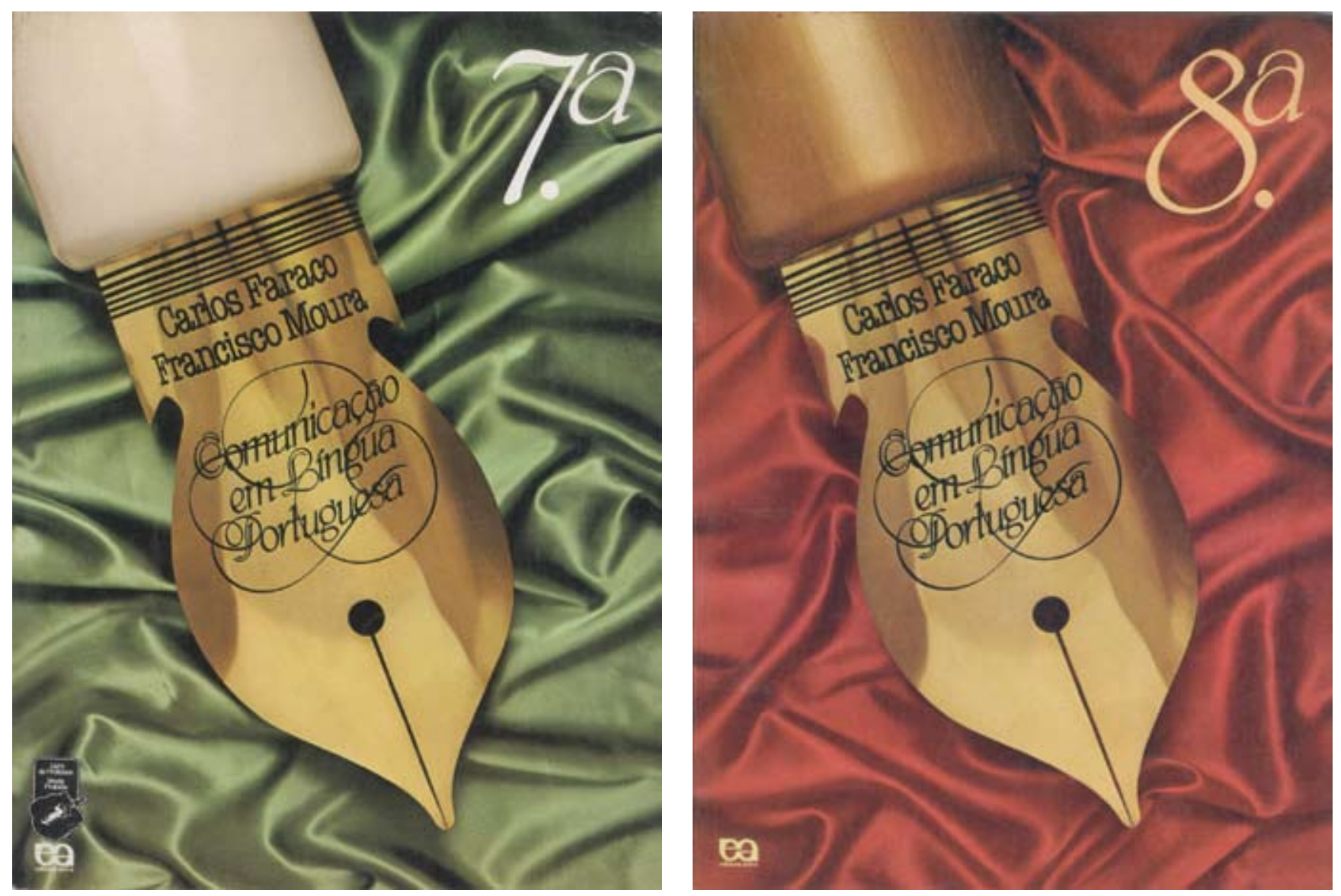

mas também a beleza e elegância obtidas, ultrapassam o sentido de clichê, ou meIhor, até se parte dele para construir um design de grande impacto e comunicação. A "inscrição" do titulo na pena, por uma sobreposição evidente, pois não se trata de uma pena gravada e depois fotografada, é um procedimento semelhante aos utilizados na construção de capas de revista conceituais, bastante generalizada. Só que em vez de reunir dois ou mais objetos com cargas simbólicas ou se modificar ou distorcer um objeto, nos dois casos obtendo-se um novo sentido, modifica-se um dos elementos com a união de um texto a ele.

É importante considerar que esse texto tem uma determinada forma, que lhe acrescenta significados. O título é construído com letras de desenho inspirado na escrita cursiva, em composição apertada e iniciais de desenho caligráfico ornamental de inspiração neoclássica. Os ornamentos prolongam-se e envolvem toda a composição criando uma nova forma muito coesa e equilibrada, com movimento visual fluido e elegante. Em contraste com ela, mas sem pesar e se sobrepor, na verdade formando um conjunto integrado pela forma da pena, estão os frisos e os nomes dos autores. Eles se relacionam formalmente com a seção mais retangular que os contém, enquanto as volutas da escrita se relacionam com o contorno curvo da pena.

O fundo de tecido sangra o campo da capa, criando o espaço sem limite necessário a uma imagem conceitual e atemporal. Com isso evita-se a presença de contornos e formas capazes de enfraquecer a percepção da imagem principal. Par- 
te desse cuidado, a informação de série se restringe ao decimal, composta com a mesma fonte do título. Mesmo em grande dimensão, repercute a elegância das formas do título e equilibra a composição diagonal. O logotipo da editora aparece à esquerda, diminuto, com muito espaço em volta e distante da pena.

A inclinação da pena, vindo do canto superior esquerdo, induz um movimento retilínio quase diagonal para o olhar, pausado pelos elementos textuais mas acelerado pelo corte da ponta da pena. Essa direção contrasta com a ondulação mais aleatória e em direções diversas da superfície do cetim e das volutas do título. 0 resultado é uma riqueza de movimentos que sustenta o interesse e dá uma complexidade a uma capa com poucos elementos.

A composição do título, transformando-o numa imagem expressiva, tem como referência o trabalho do designer norte-americano Herb Lubalin.

Visando o reconhecimento pelo professor, para a quarta capa é mantida uma relação com as capas da edição anterior, com a fotografia de uma caixa de objetos que formam a palavra comunicação. Assim, os novos alunos terão também a possibilidade de participar do mesmo jogo de decodificação proposto na primeira edição. Alguns objetos são reaproveitados, mas o arranjo é novo e igualmente sugestivo. O resultado é um contraste muito grande entre as soluções de primeira e quarta capas, uma liberdade que só designers de formação não modernista poderiam tomar.

\section{Comunicação em Língua Portuguesa. Quarta capa. Ilustrações e objetos Ary A. Normanha, Aderbal Moura, Paulo César Pereira, René Etiene Ardanuy, Alcides Batista e Lázaro Mendonça (marcenaria). Fotografia Delfim Fujiwara.}

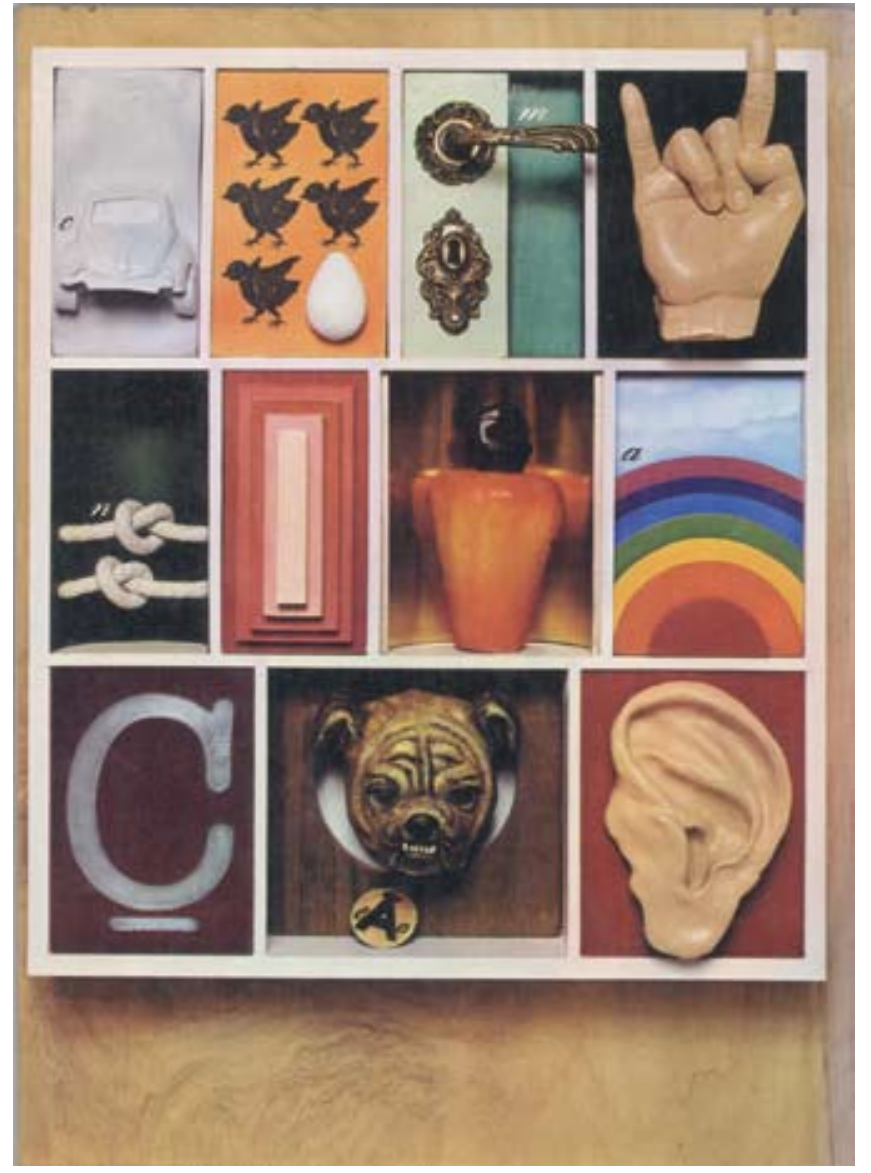




\subsection{A ilustração e a fotografia referencial}
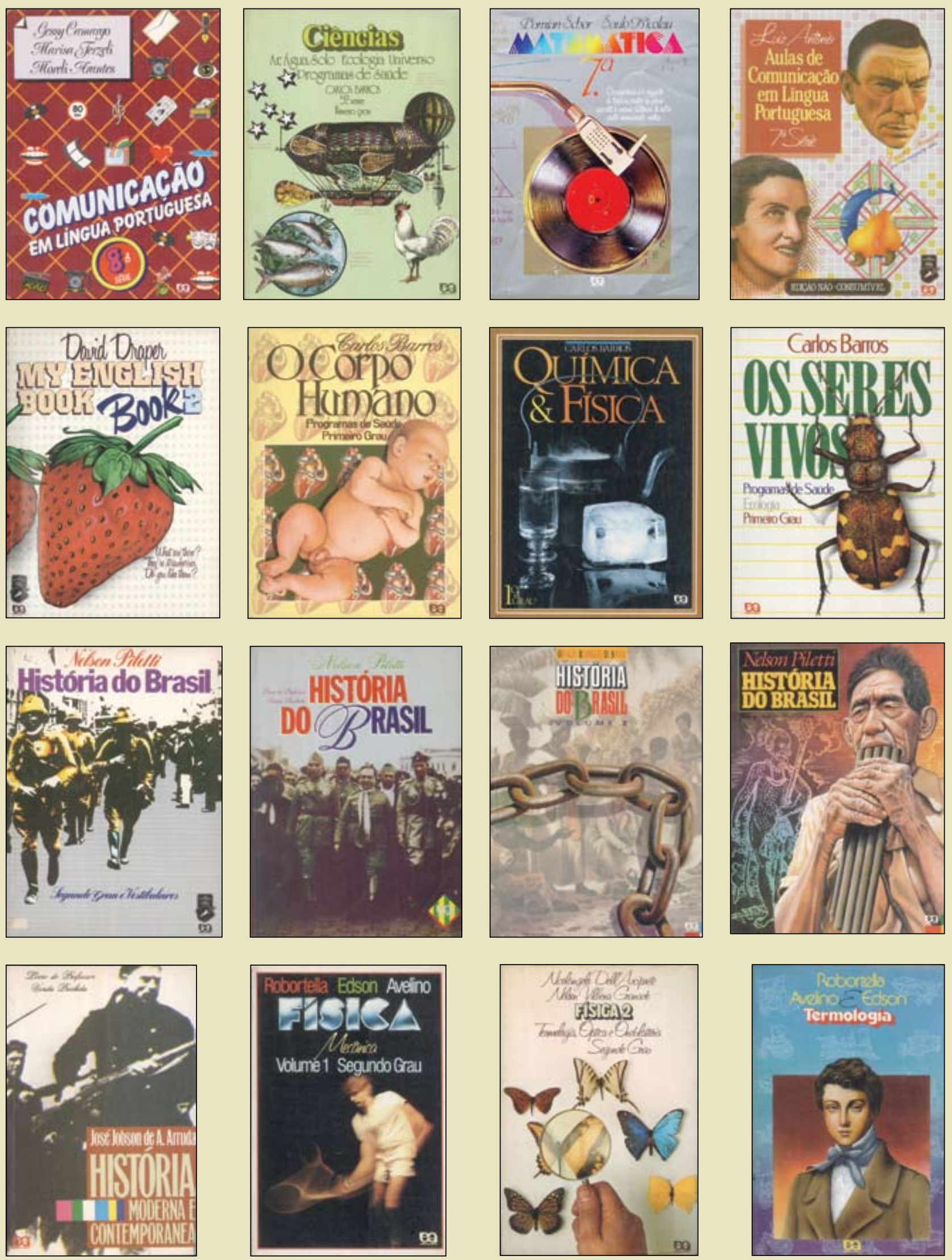
${ }^{14}$ Em seu depoimento, Ary Normanha menciona o pedido de empréstimo de um espécime de vitória-régia ao Jardim Botânico do Rio de Janeiro, que veio e retornou de avião com custos da Editora, para ser fotografado em estúdio em condições que propiciassem uma diferença em relação às fotografias existentes em bancos de imagem. Não encontramos esta capa para reproduzir.
Embora as capas da página anterior sejam bastante diversas quanto às soluções formais, o que motiva seu agrupamento aqui são as referências mais ou menos direta ao conteúdo do volume a partir do uso e da exploração de imagens extraídas do universo das disciplinas.

Em todas elas, mesmo nas de montagem fotográfica, o conteúdo da disciplina está presente e não há ambiguidade ou prejuízo da informação neste aspecto. Mas aqui a iconografia própria das Ciências ou das matérias tratadas é a estratégia comunicativa principal. Como vimos, Ary Normanha reconhecia expectativas em grande número dos professores em encontrar o conteúdo de sua disciplina retratado na capa, mas afirmava que sempre era possível fugir das soluções convencionais e surpreender. Assim evitava utilizar as imagens mais recorrentes ou procurava dar um tratamento diferenciado a elas. ${ }^{14}$

Em capas de livros didáticos de História, em que o aspecto documental e uma iconografia tradicional e oficial estavam sempre presentes, Normanha usou da ilustração realista baseada em fotografia e mesmo da manipulação de imagens e de documentos fotográficos. Ao aspecto documental, Normanha acrescentava a exploração das qualidades plásticas da imagem e esse era o critério fundamental para sua escolha, geralmente ignorado no uso de imagens referenciais, mesmo em situações de capa.

Em Ciências exatas e biológicas, o uso de iconografia tradicional, anterior à fotografia, ou o hiper-realismo no lugar das fotografias introduziam uma nova dimensão à representação exigida pela objetividade científica, às vezes com carga poética e de forte interpretação pessoal. Para isso, o designer apoiou-se no trabaIho de excelentes fotógrafos e ilustradores, pois a questão não é o tema em si, mas como ele é realizado plástica e graficamente.

Se nos volumes destinados ao ensino de primeiro grau e em disciplinas como Português, Inglês ou mesmo Matemática havia a possibilidade de interpretações metafóricas ou mais genéricas do conteúdo, nas capas de disciplinas científicas de segundo grau, o atual ensino médio, a identificação dos conteúdos do volume foi tratada como exigência a que não se podia fugir, mas nem por isso recebeu tratamento convencional.

As capas de Português puderam trabalhar com ilustração de maneira bastante livre, principalmente devido à associação com o sentido de comunicação da língua e da presença forte da arte literária. As capas de Inglês se apoiavam na iconografia bastante ampla da cultura de massas norte-americana e inglesa, de forte penetração entre os jovens e mesmo professores, e foi onde os designers e ilustradores da Ática encontraram maior liberdade para criação. 


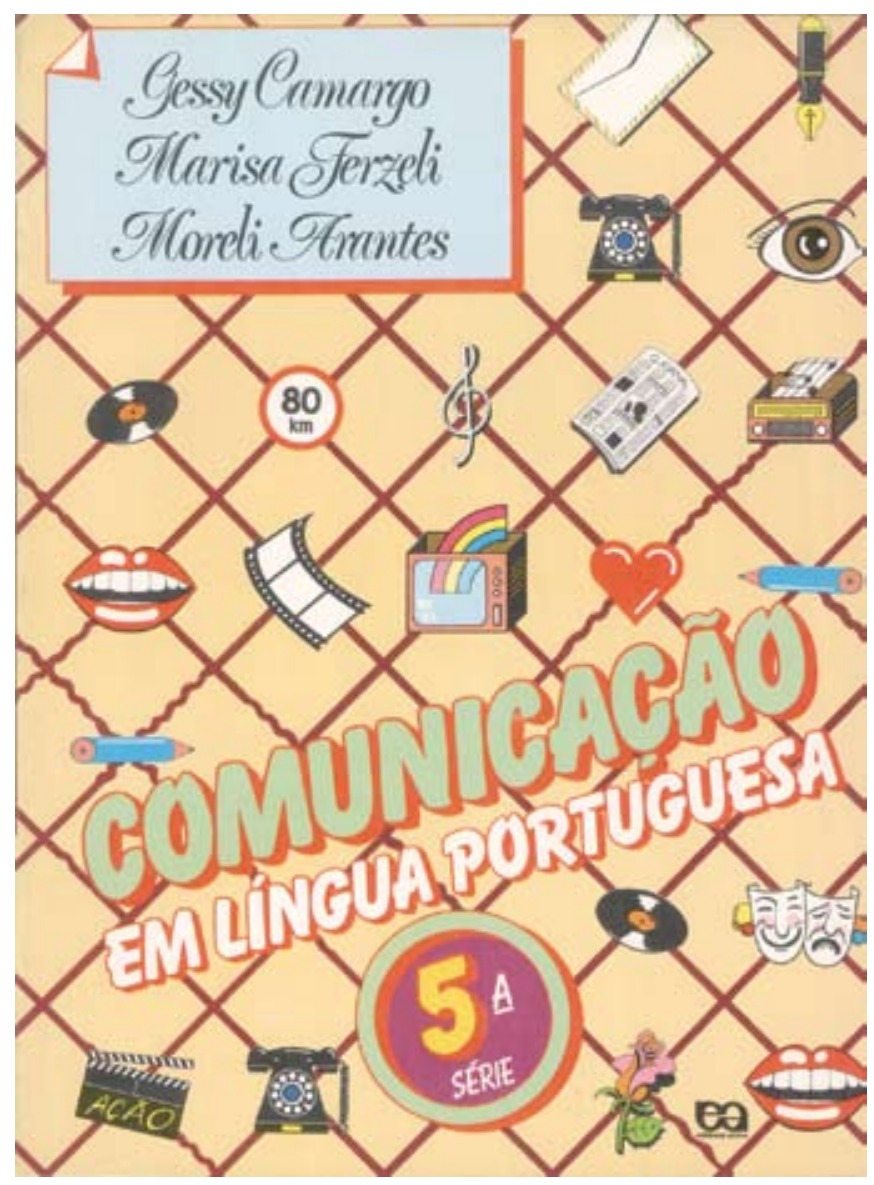

Comunicação em Língua Portuguesa - Camargo, Ferzelli e Arantes

Uma coleção de objetos e instrumentos alusivos à comunicação — trata-se de uma estrutura visual a que poderíamos chamar conceitual, em que os elementos representados são reunidos por pertencerem a uma mesma classe, por possuírem um mesmo significado essencial a despeito de sua diversidade e procedência. Todas as figurinhas ocupam a mesma área, fora de seu contexto original e num mesmo plano frontal e a distâncias iguais, definidas pela estrutura linear diagonal, o que as iguala e as subordina a uma mesma ideia ou significado geral, a de comunicação (e talvez as una pelas linhas, que em alguns pontos ziguezagueiam). A diversidade de formas e coloridos, a diagonalidade da trama, a inclinação do título conferem a dinâmica que a ideia de comunicação implica, particularmente no momento em que ela foi introduzida como sendo a razão de ser do uso da língua, como nas décadas de 1960 e 1970 a partir das ideias da linguística estruturalista impactada pelos meios de comunicação de massas. (Imagine-se a estaticidade que haveria caso a trama fosse ortogonal e o título horizontal.)

A fonte utilizada no título - Ballon, criada nesses anos, de desenho arredondado, informal e espontâneo, com a sombra incorporada — comunica por si esse "espírito do tempo". A linguagem das ilustrações, a estilização pop dos objetos, com seus brilhos e volumes, tem a marca de Cafiero e é inspirada no trabalho do PushPin Studios, como o próprio designer admite.
Comunicação em Língua Portuguesa. Gessy Camargo, Mariza Ferzali, Moreli Arantes. 1. ed.,1981. Design e ilustrações Mário Cafiero. $(27,5 \times 20,5 \mathrm{~cm}$; plastificada.)

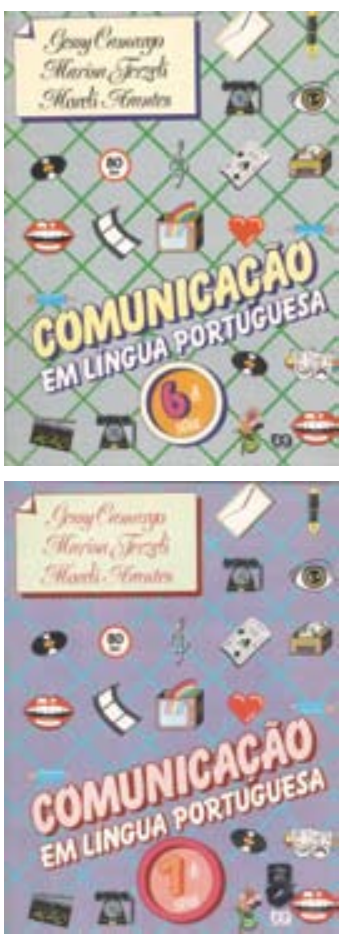



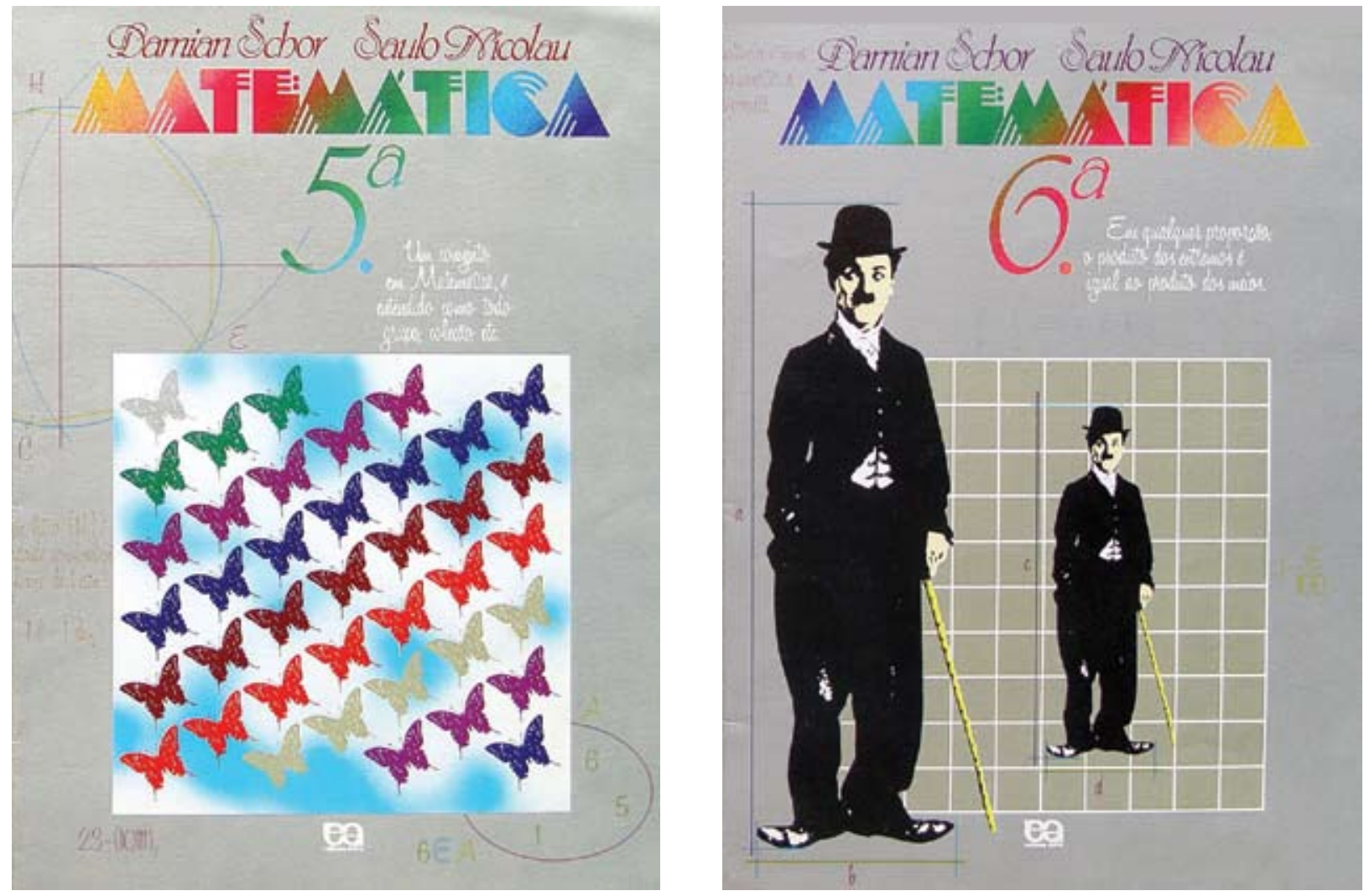

Matemática. Schor e Nicolau. 1981. Design e ilustrações Ary Normanha. $(27,5 \times 20,5$ $\mathrm{cm}$; plastificada.)

Na página seguinte, capas e quartas capas das 7. ${ }^{\mathrm{a}}$ e $8 .^{\mathrm{a}}$ séries.

\section{Matemática - Schor e Nicolau}

Para um professor de Matemática entuasiasmado, deparar com uma equação ou uma solução elegante de um problema pode ser algo que produza um prazer intelectual semelhante ao estético, no sentido de produzido pelos sentidos. Mas como traduzir conteúdos e conceitos abstratos que não se expressam por formas visualmente atraentes, em uma visualidade motivadora e comunicativa tanto para alunos de 11 a 15 anos como para seus professores? Esse é o desafio que está dado para um design dirigido a dois públicos, um que aprecia reconhecer o conteúdo disciplinar e decide pela adoção do livro e outro que precisa ser motivado cotidianamente por outros estímulos.

Essas capas optaram por utilizar os conteúdos disciplinares explicitamente, mas através da estratégia de encontrar imagens que traduzissem ludicamente os conceitos envolvidos e apresentá-las num design de forte apelo visual. A coleção de borboletas coloridas para expressar a noção de conjunto, a dupla do sempre simpático Carlitos para mostrar a proporção, a arte hiper-realista do então valorizadíssimo toca-disco, o desenho quase técnico do jato numa exuberante mas estilizada mata, todos em linguagens gráficas bem diferentes que conferem variedade a uma estrutura básica comum, em que um quadrado aparece em todas as capas. O sofisticado fundo em tinta metálica prata, os escritos e desenhos preenchendo o campo e o multicolorido título em geometria original, compondo-se com a elegante fonte manuscrita do nome dos autores e do grande número da série, completam esse atraente desenho, que se estende até a quarta capa.

Na verdade, pode-se ver que o conteúdo é pretexto para a construção de um 

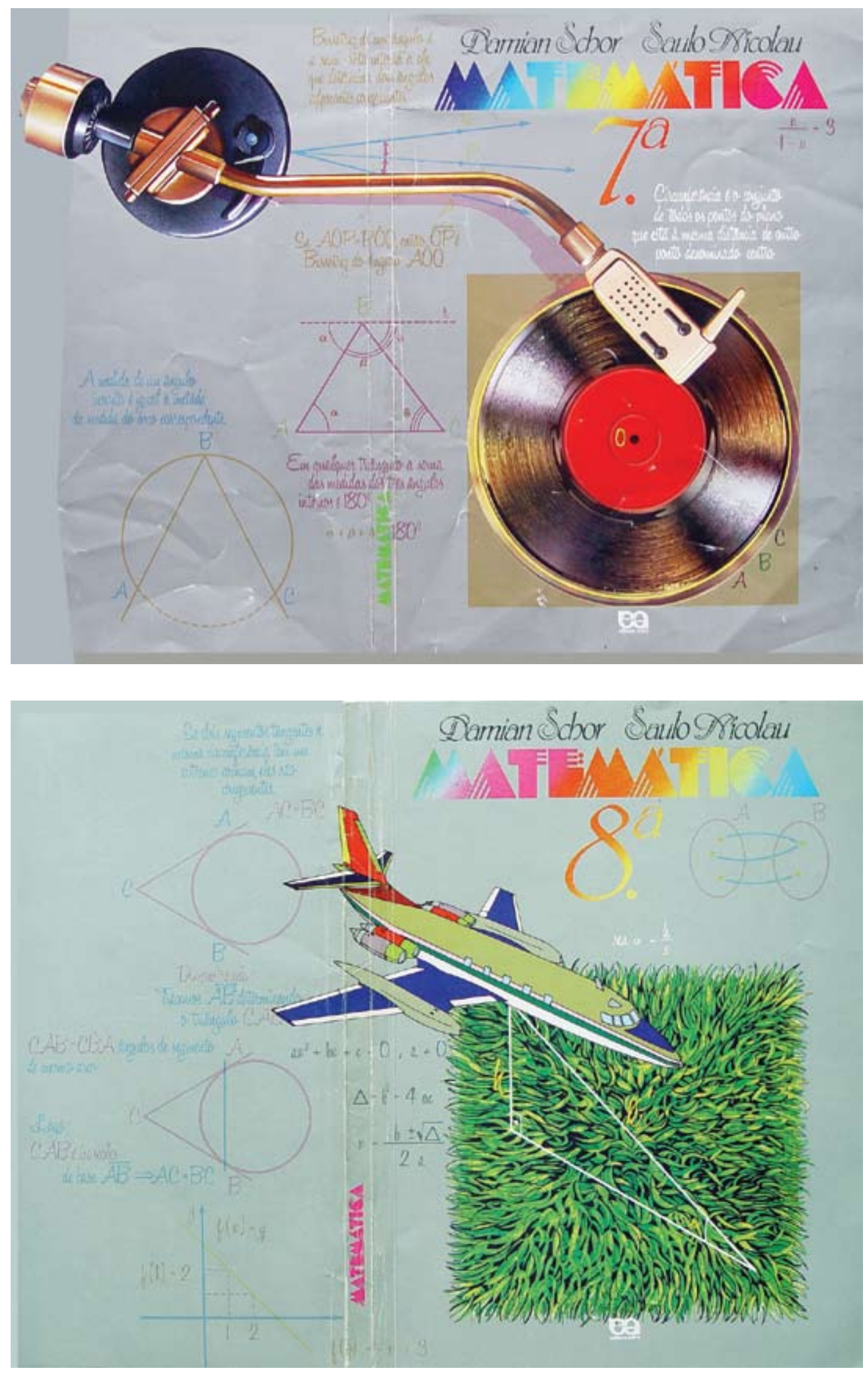

belo design e ele é que, de fato, é o "conteúdo" que vai sensibilizar e motivar, tratando como iguais os dois públicos a que se dirige. Assim, a beleza da forma não pode ser desprezada mesmo quando se trate de atingir quem supostamente valorize apenas aspectos intelectuais e conteudísticos. 

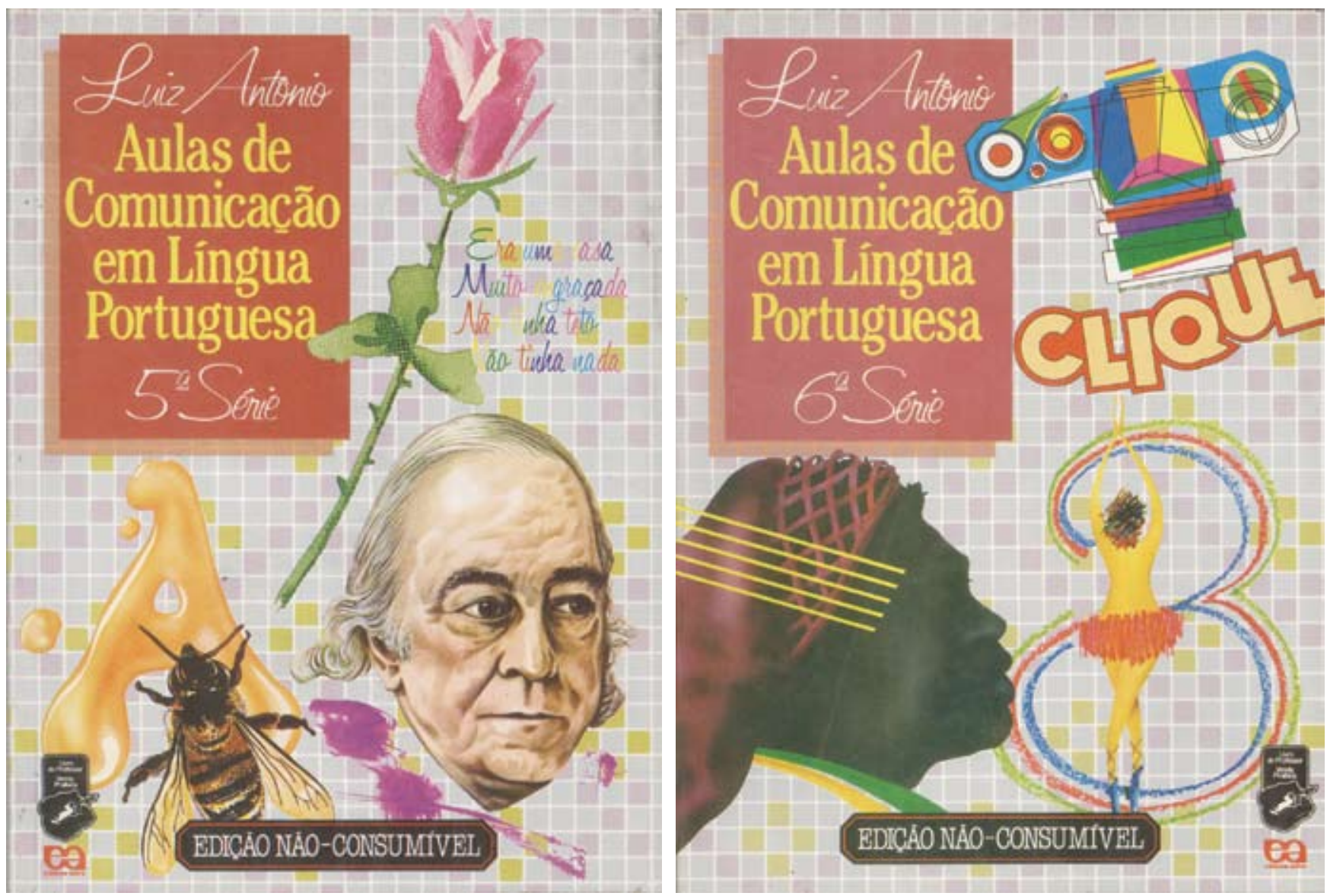

Aulas de Comunicação em Língua Portuguesa. Luiz Antônio. 1. ed., 1984. Design Ary Normanha. Ilustrações Ary Normanha e Paulo César Pereira. (27,5 x $20,2 \mathrm{~cm}$, plastificada). Editor Avelino Correa/ Sandra Almeida.

\section{Aulas de Comunicação em Língua Portuguesa - Luiz Antônio}

O impacto e poder de sedução dessas capas decorre da riqueza das ilustrações, com sua variedade de linguagens, qualidade de execução, atenção para os detalhes, liberdade de composição e mesmo conteúdo e qualidade da informação que elas veiculam. $O$ tratamento do fundo - uma malha quadricular com impressão em prata e variações aleatórias de tonalidade que quebram sua regularidade, criam ritmo visual e a qualificam e enriquecem — é decisivo para integrar as imagens como formando uma única ilustração de que esse fundo faz parte e tem qualidades mesmo de ilustração.

O retângulo que contém o título é também uma forma que integra a composição geral. Sua ortogonalidade contrasta com as formas mais livres e complexas das figuras, o que serve para exercer seu papel de receber e destacar o título e unificar nas várias capas a identidade da coleção, ao mesmo tempo que valoriza as ilustrações pelo contraste radical com elas (isto parece óbvio, mas pode-se imaginar que essa forma poderia ser curva, amebóide, com enfraquecimento do conjunto). Mas na fonte do título predomina o desenho curvo, no acabamento das serifas e terminações em gota, e variações de espessura, além do desenho manuscrito do nome do autor, ambos em acordo formal com a linguagem das ilustrações. A regularidade da caixa de informações textuais e seu posicionamento comum nas quatro capas comunicam a ideia de informação dada, pressuposta, enquanto a irregularidade e aleatoriedade das ilustrações comunicam a ideia da informação 

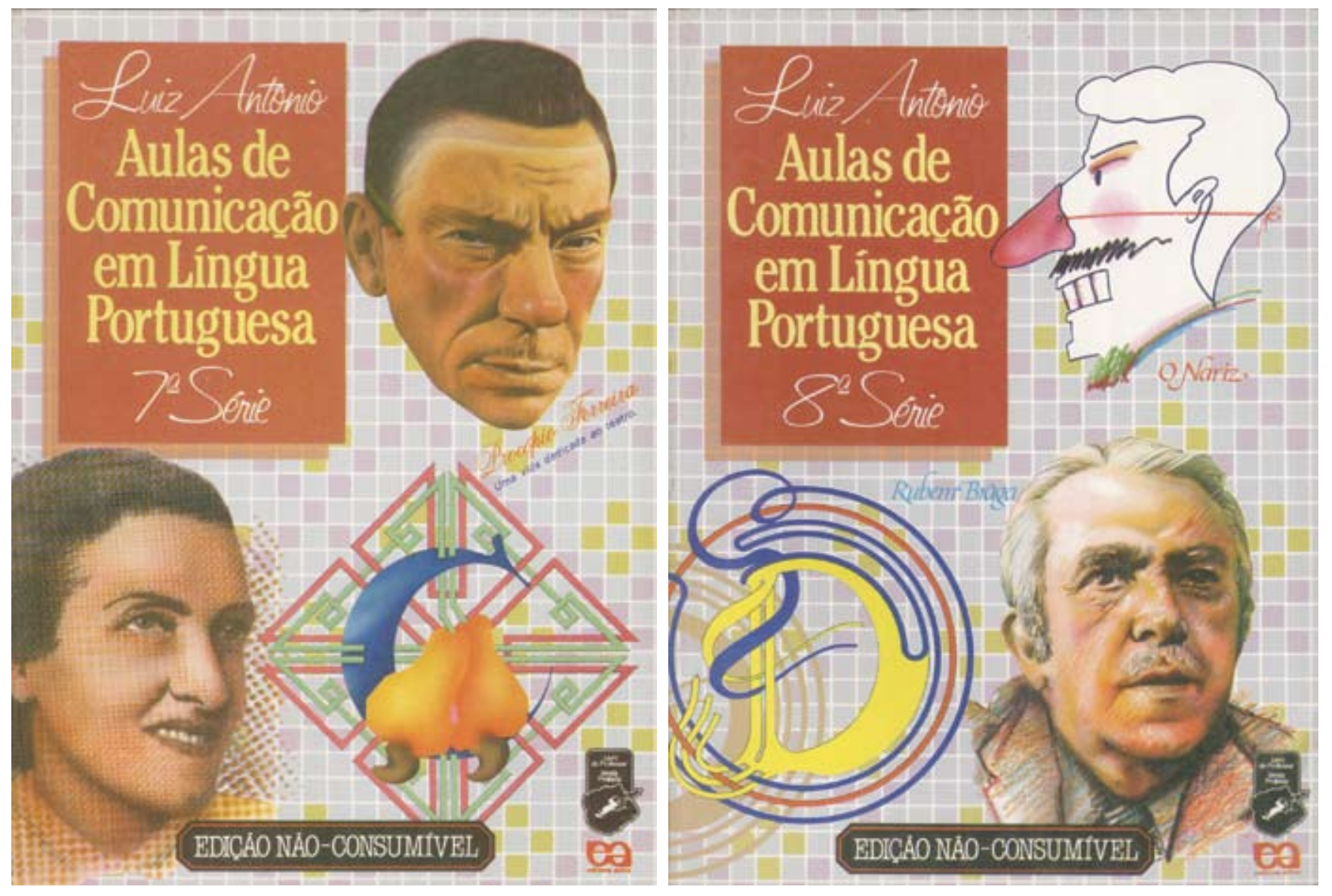

nova, acrescida, imprevisível, o que explica a recorrência desse tipo de recurso, mas nem sempre tão bem executado.

Não há um esquema de composição fixo nas capas, em que retratos e outros elementos repetem posições, quantidade, assuntos e tratamentos plásticos. Os retratos naturalmente se destacam, pelo volume do tratamento"realista"da aerografia sobre base fotográfica em contraste com as outras figuras mais planas ou lineares, mas também porque culturalmente somos induzidos a valorizar a representação da figura humana, nesse caso ainda revestida do que elas representam. Mas todas as imagens são elaboradíssimas, e o conjunto delas equilibrado em seu contexto.

Note-se que as imagens originaram-se da leitura do conteúdo, pois não faria sentido o retrato de um autor ou uma ilustração de um tema que não fizesse parte do volume em questão. Mas também não faria nenhum sentido atribuir um valor indicial do conteúdo do volume a elas, pois são tantos os outros conteúdos que isso resultaria totalmente arbitrário. Assim, pode-se dizer que as imagens foram claramente pensadas a partir da ideia do significado mais amplo da coleção, pois formam um panorama da cultura brasileira, da poesia ao teatro, da canção popular às próprias linguagens plásticas. Em vez de dizermos pensadas, talvez seja melhor dizer criadas, concebidas plasticamente como composições visuais para, além de informar culturalmente, também deleitar e seduzir, e assim atrair o potencial leitor a abrir e conhecer o livro, e não estreitamente para informar e classificar conteúdos pontuais.

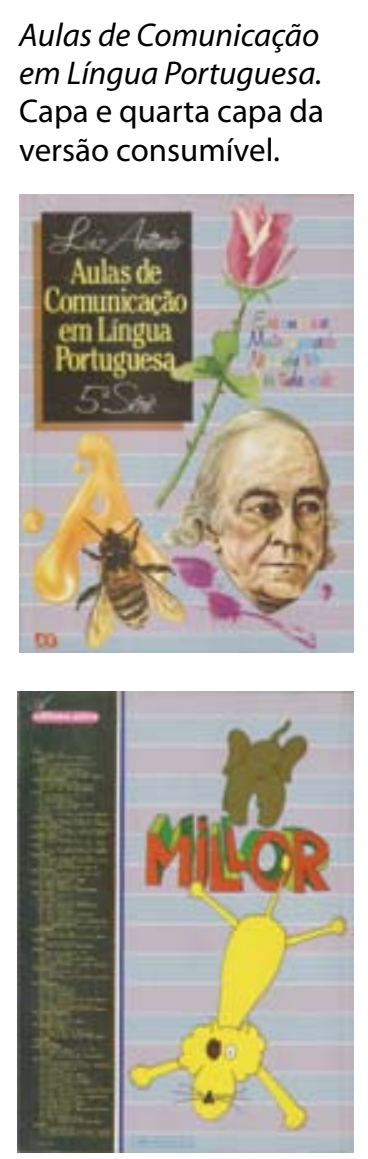




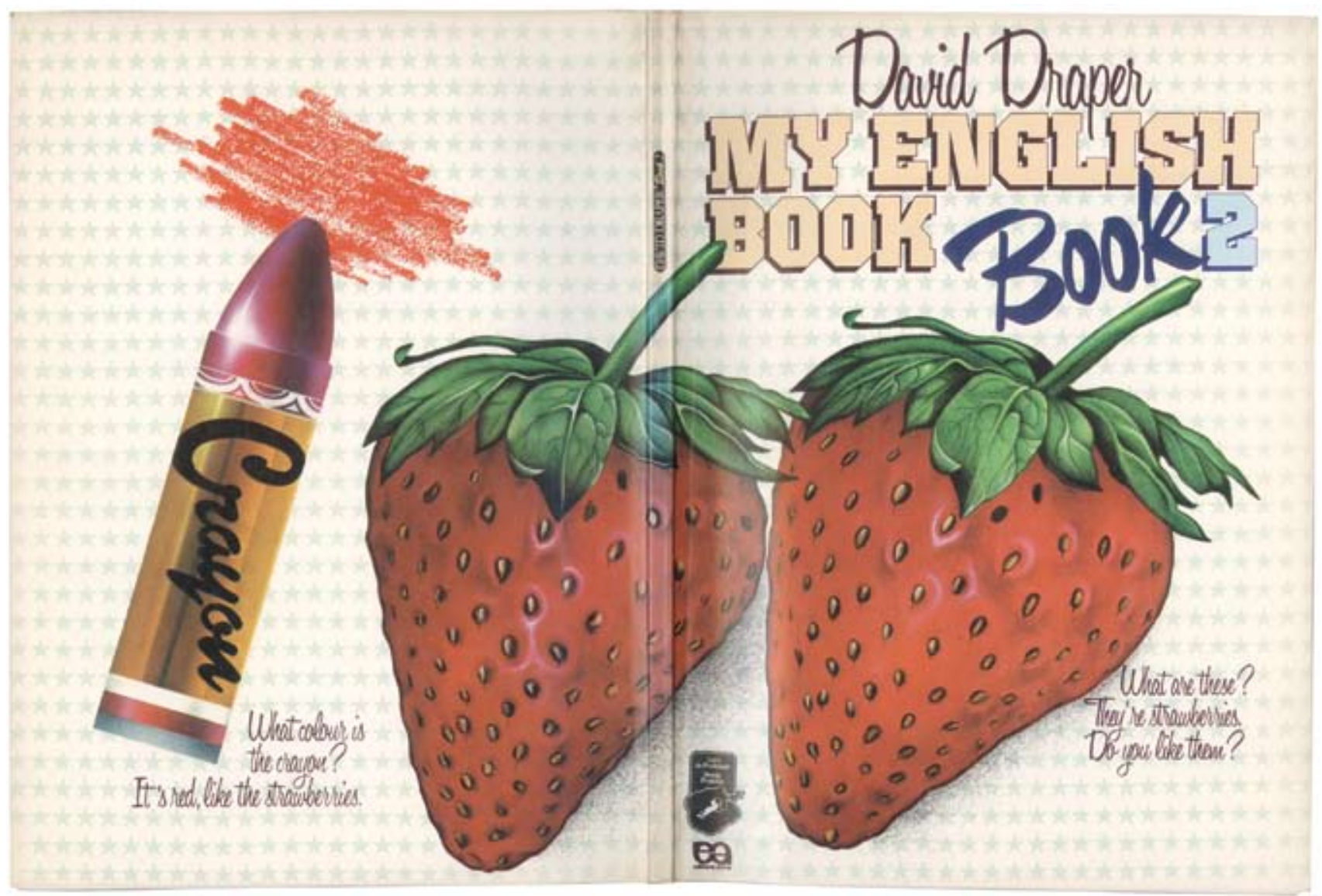

My English Book. David Drapper. 1. ed.,1982. Design Ary Normanha. llustrações Paulo César Pereira e Aderbal Moura. $(20,5 \times 27,5 \mathrm{~cm}$; plastificada.)

As quartas capas apresentam sempre um crayon com uma frase relativa à alguma cor da ilustração.

\section{My English Book - David Drapper}

A solução de desenho das informações de título, autoria e volume, uma composição muito coesa realizada por contrastes acentuados de formas dos tipos, tem grande importância para a forte identidade da coleção. A letra compacta formada só de traços retos e serifas curtas de altura quase idêntica à largura das hastes (egípcias), acrescida da sombra, cria um título com volumetria contrastante com os traços finos e variáveis da letra de desenho manuscrito estreito e plano. O espaço vazio entre o título e o número do volume ocupado por uma letra de traço de pincel (Brushscript), inclinada e quebrando o alinhamento e a geometria, particulariza ainda mais essa marca, e mal se percebe que há uma repetição de palavra tal a diferença de suas formas e a pregnância do conjunto.

O padrão de fundo e a linguagem da ilustração completam essa identidade no aspecto de percepção mais imediata da forma. E a relação entre as figuras escolhidas e os pequenos textos, mais o que ocorre na quarta capa, completam o significado, a ideia mais profunda que sustenta a comunicação e traduz o sentido de livros de inglês voltados para o primeiro grau. Pois, excetuando o jogador e, em menor grau, o personagem de Oliver Hardy, as demais imagens não traduzem por si a idéia de língua inglesa. As imagens dominam, não são ilustrações dos textos, mas é a presença deles que dão o sentido às capas, independentemente da relação com cada figura. Assim, aparecem como legenda, afirmações ou perguntas que não modificam o sentido de cada imagem em particular, pois não estão aí 


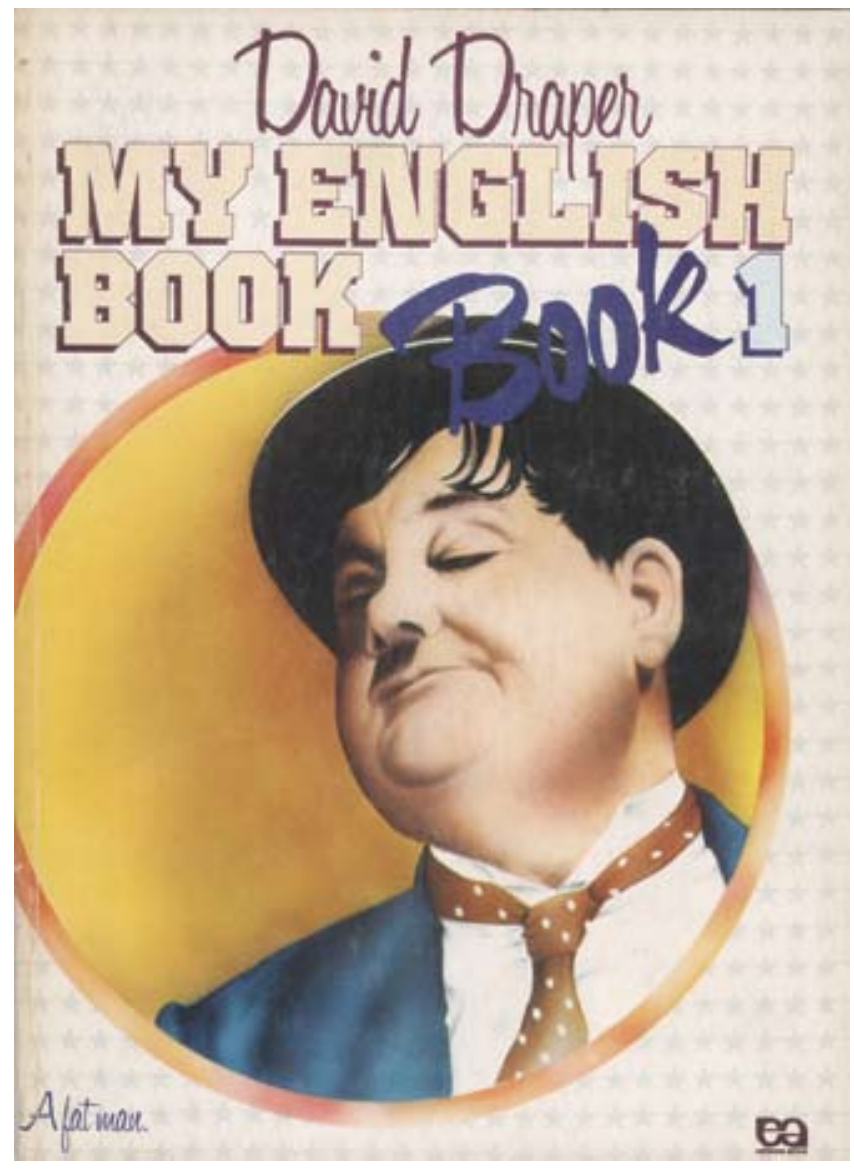

para ensinar. O diálogo entre textos e figuras, ou as "lições", particularmente ampliadas na quarta capa, são apenas pretextos para comunicar a ideia de coleção de Inglês através de um design sugestivo e cativante.

A figura do volume 3 - talvez a menos atraente e mais ambígua, mas também instigante - apresenta uma diferença fundamental com as demais. Enquanto estas são de tipo expositivo, mostram alguma coisa, aquela tem um componente narrativo: o corpo do gato funciona como um vetor, tem uma direção diagonal acentuada, que corresponde a uma postura ativa visando uma meta que ainda desconhecemos, mas que está indiciada por um elemento de que só vemos uma parte, ficando claro que é preciso virar o livro para elucidar a ação e completar a história. Mesmo a figura do livro 4, que está em desequilíbrio e no meio de uma ação, pode ser tomada como uma imagem expositiva, que mostra o que e como é um jogador em movimento, e não narrativa, ainda que o texto a ela agregado seja uma afirmação de caráter narrativo, com uma dimensão temporal.
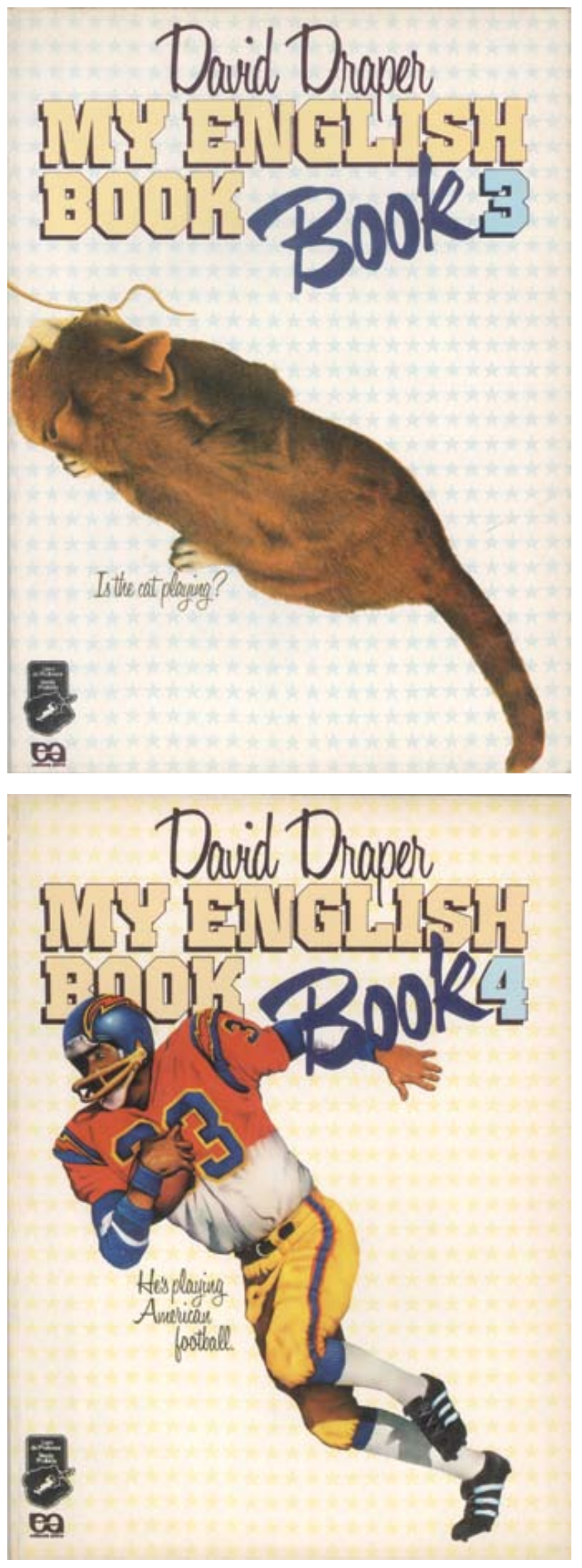

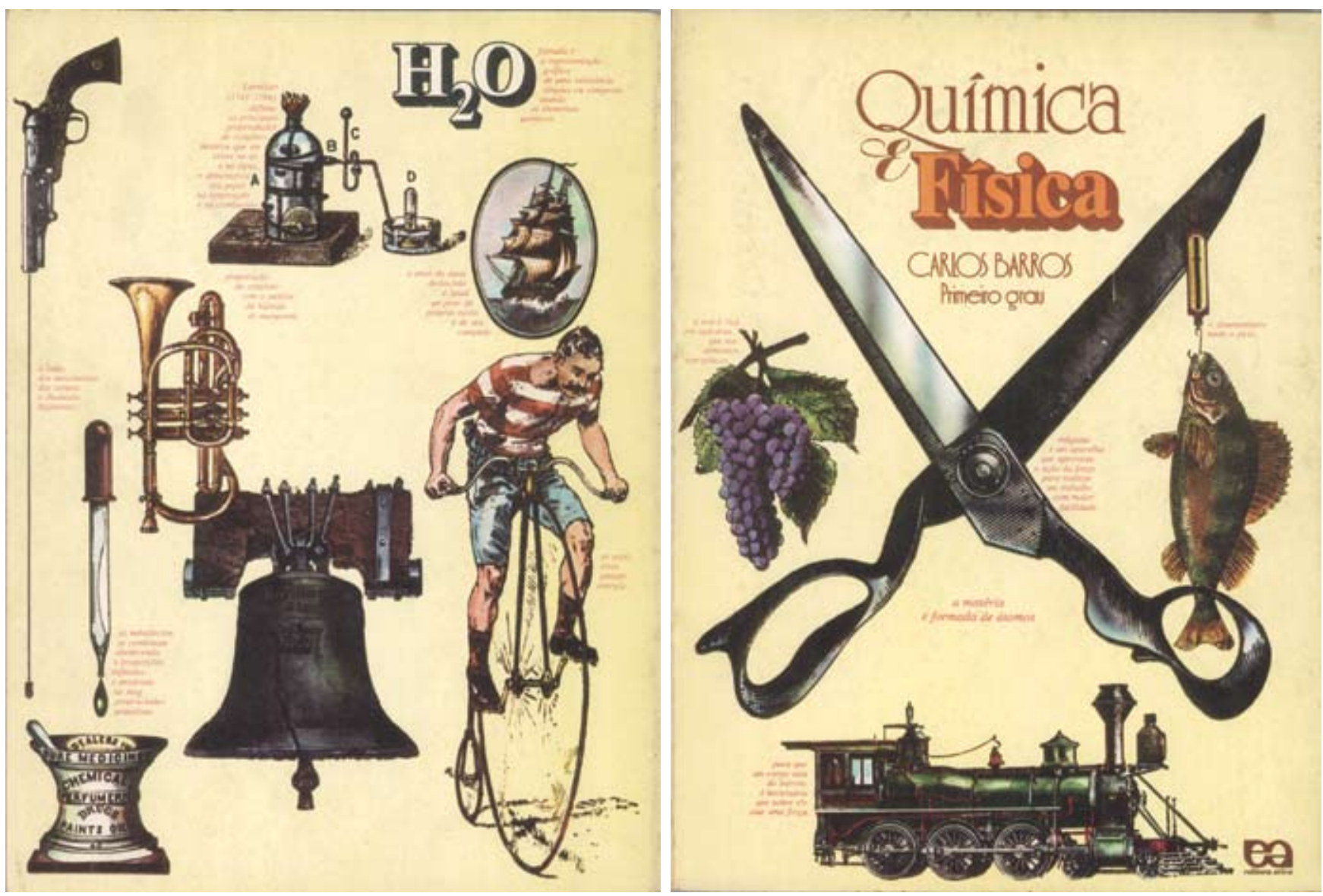

Design Ary Normanha e Mário Cafiero,

1978. $(20,5 \times 27,5 \mathrm{~cm}$; plastificada.) Editor João Guizzo/José Antonio dos Santos.

Capa e quarta capa.

Abaixo, outro volume da mesma coleção.

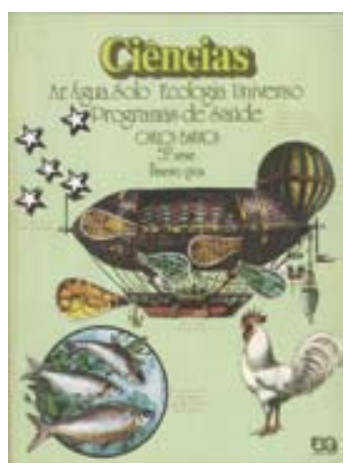

15 Eletrotipia ou galvanotipia: "Processo de confecção de eletrótipos, planos ou curvos, pela moldagem a quente de plástico ou cera a partir de uma matriz original gravada em alto-relevo, produzida por galvaniZação." (ROSSI FILHO, 2001)

\section{Química e Física - Primeiro Grau - Carlos Barros}

O sabor particular dessas capas é dado pela linguagem das ilustrações, todas elas originárias de livros de referência, dicionários ou enciclopédias, ou mesmo de publicidade do século XIX e começo do XX, desenhadas para serem reproduzidas por eletrotipia ${ }^{15}$. Essas ilustrações, conhecidas como electrotypes (na verdade, os clichês), geralmente de autoria desconhecida ou com direitos autorais vencidos, foram reunidas em álbuns conhecidos como compendiuns, muito divulgados nos anos 1960 e 1970 a partir do interesse dos designers americanos e ingleses por essas fontes históricas. Aqui, influenciado por esse movimento revivalista principalmente conduzido pelo Push Pin Studio, de Nova York, Mário Cafiero as recicla colorizando-as com aerógrafo e obtendo volume e brilhos bem ao gosto pop contemporâneo. Mas diferentemente das mencionadas capas do Comunicação em Língua Portuguesa (ver página 129), faz uma composição mais elaborada, dimensionando e distribuindo as formas de maneira mais livre. Os objetos são escolhidos a partir dos conteúdos tratados pelo volume, que é explicitado pelas pequenas definições aplicadas ao lado das ilustrações, que entram na composição enriquecendo-a, pelo contraste formal e de cor.

O fundo neutro, chapado, torna as imagens referenciais apenas a seu significado e faza capa conceitual, isto é, dizendo respeito a significados mais essenciais e generalizáveis, e não a circunstâncias específicas e anedóticas, o que corresponde ao sentido mais básico do conhecimento científico. 

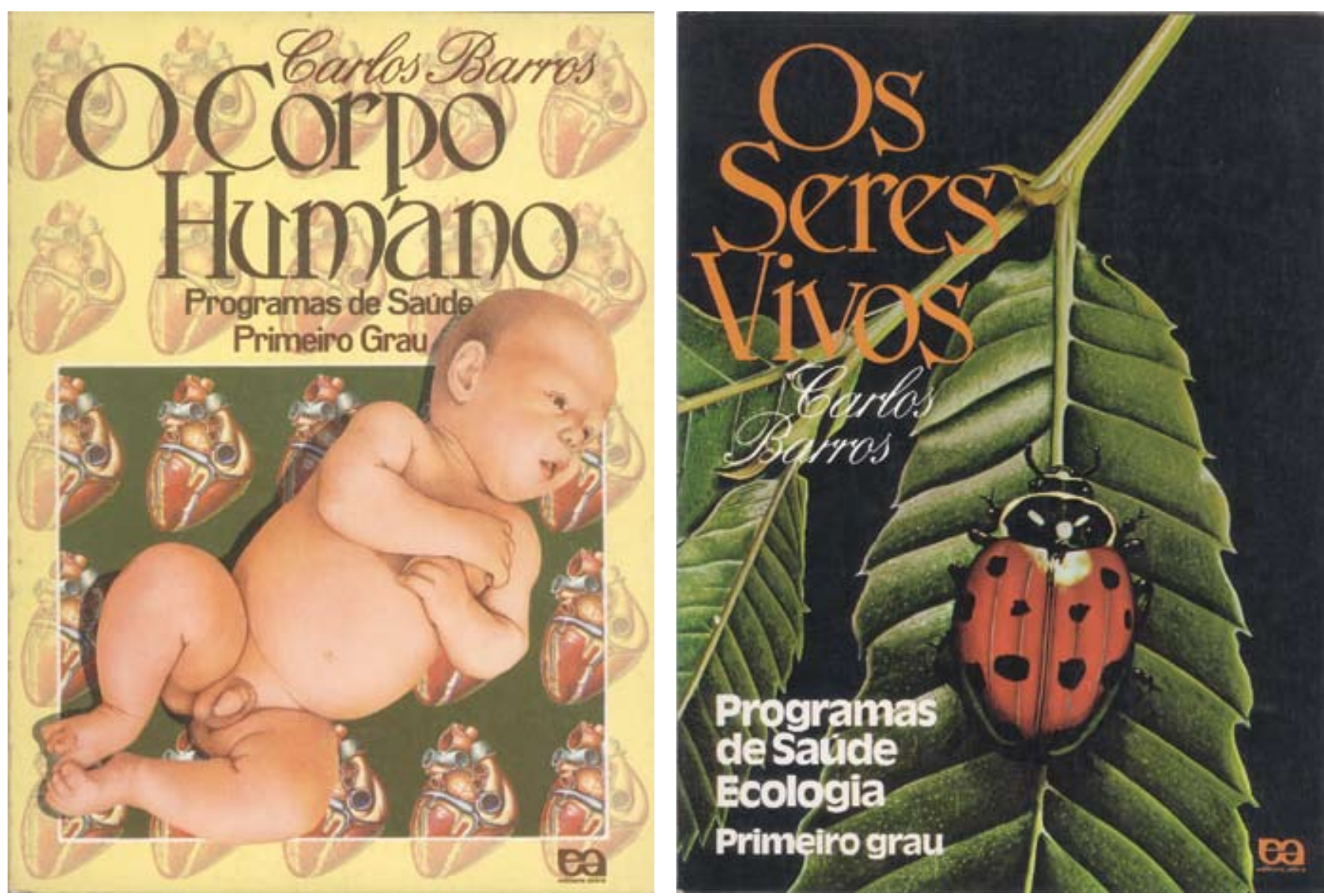

\section{O corpo Humano e Os seres vivos - Carlos Barros}

Estas capas têm em comum a tipografia das informações textuais e a ilustração referencial à realidade, mas apresentam diferentes organização do espaço e abordagem dos elementos representados, com consequências para o sentido. $\mathrm{Na}$ da esquerda, o realismo baseado em modelo fotográfico é evidente. No entanto, esse bebê pintado como uma fotografia, repousa sobre um plano gráfico completamente artificial, formado por um padrão composto pela repetição de ilustração realista, tanto quanto pode ser a representação de um órgão interno retirado de seu contexto, e por uma "janela" que serve tanto para evidenciar graficamente a presença do coração como para circunscrever e destacar o bebê do primeiro plano. Mas a representação do coração pode ser tomada como perfeitamente realista, pois a verdade em ciência comporta a ideia de modelo generalizável que apresenta a essência do funcionamento e a aparência das coisas. Sua repetição reforça esse sentido "abstrato" geral de órgão responsável pela vida que a representação realista do bebê concretiza eloquentemente.

A capa da direita se comporta como uma tomada ou instantâneo da realidade, uma vez que idealmente há um espaço natural para além do quadro da capa, o qual delimita esse espaço focalizando seres dessa natureza. As informações textuais estão num plano à frente evidenciando esse recorte naturalista. Nesse sentido é mais realista que a capa anterior, embora seu tratamento seja assumidamente pictórico e busque, pela estrutura compositiva, relação figura-fundo e acentuação dos volumes e luzes mais efeitos plásticos expressivos do que realismo puro e simples.
O corpo humano. Carlos Barros. 12. ed., 1981.

Design Ary Normanha e Mário Cafiero. llustração Paulo César Pereira. $(20,2 \times 27,5 \mathrm{~cm})$. Editor Wilma Silveira R. de Moura.

Os seres vivos. Carlos Barros. 3. ed., 1979. Design (?) e ilustração Geraldo Moura. $(20,2 \times 27,5 \mathrm{~cm})$. Editor Maria Izabel Simões Gonçalves. 

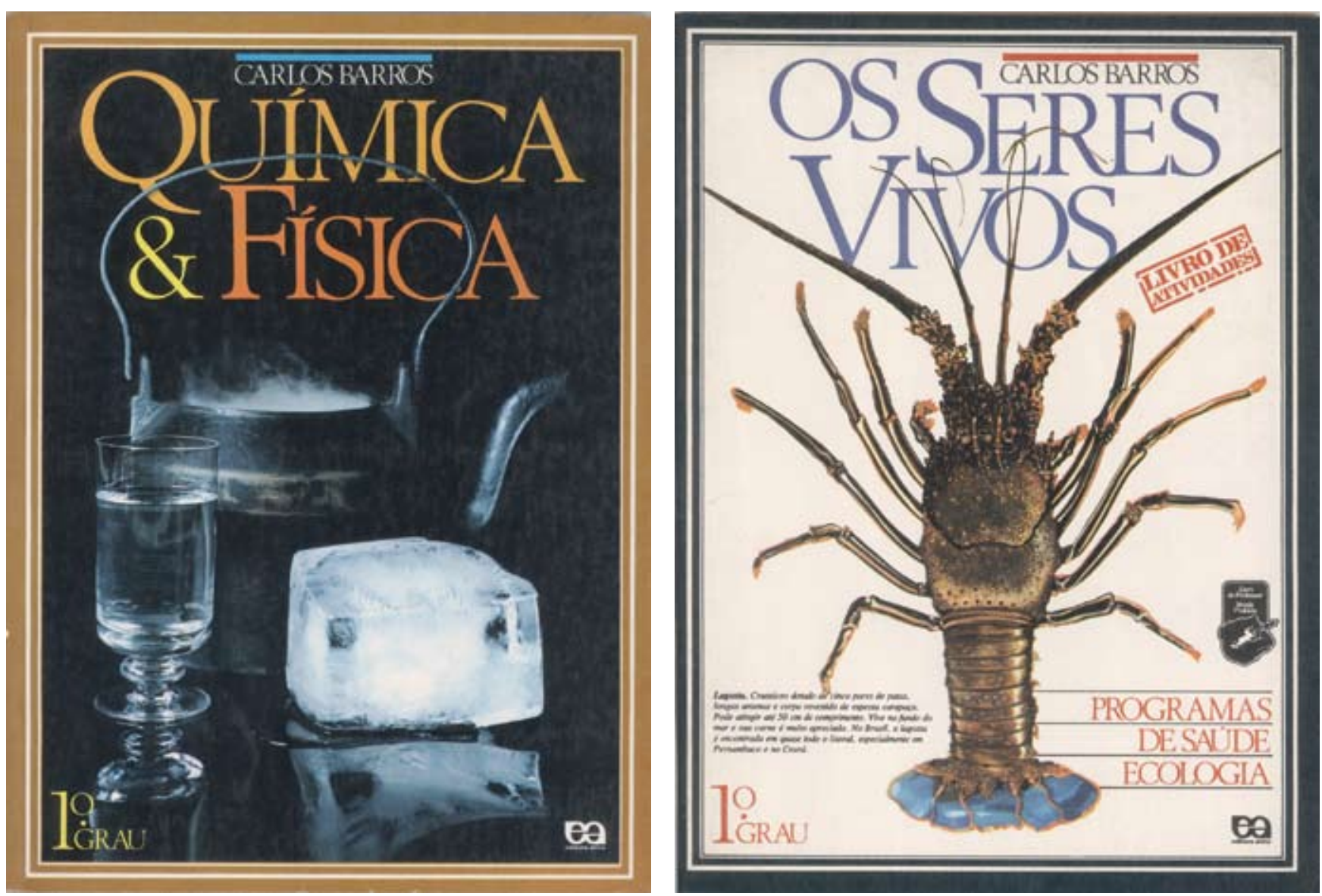

Química e Física. Carlos Barros. 7. ed., 1982. Design Mário Cafiero. Fotografia Delfim Fujiwara. (27,5 x 20,4 cm; plastificada). Editor João Guizzo/José Antônio dos Santos.

Os seres vivos. Carlos Barros. 23. ed., 1985. Design e ilustração Mário Cafiero.

$(27,5 \times 20,4 \mathrm{~cm}$; plastificada). Editor João Guizzo/Maria Izabel Simões.

\section{Química \& Física e Os seres vivos - Carlos Barros}

Embora pertencentes à mesma coleção - e por isso tendo um mesmo layout básico — as duas capas apresentam soluções diferentes para a representação referencial presentes nas capas dessa disciplina. Por que as duas não são igualmente fotografias ou ilustrações? O impacto de representar o fenômeno físico dos três estados da matéria da substância água num único espaço e momento só existiria com o apelo aos sentidos propiciado pela captura fotográfica precisa e controlada das qualidades da substância em cada um desses estados. Mas o tom azulado comum, sem deixar de preservar as características de cada representado, une ainda mais esses objetos e estados do que sua simples contiguidade. Os tons quentes do título contrastando com a tonalidade fria dominante também reforçam a apreensão unitária do conjunto. O resultado é que esse mesmo espaço físico acaba sugerindo ou representando a existência de um mesmo espaço mental onde se podem reunir estados e ideias que os interpretem e que o mundo real apresenta separados.

A lagosta da capa da direita foi claramente ilustrada sobre uma fotografia e talvez isso a torne mais interessante e atraente que a apresentação através da fotografia. Além de a ilustração ser uma prática nas ciências naturais que a fotografia não aboliu, por permitir a seleção e o ressalto de detalhes de interesse que esta iguala e faz desaparecer, a ilustração que procura reproduzir realisticamente o efeito da luz nos volumes e as qualidades táteis de superfícies diferentes, na realidade criando um realismo exagerado, parecia exercer grande fascínio particularmente nos jovens. 

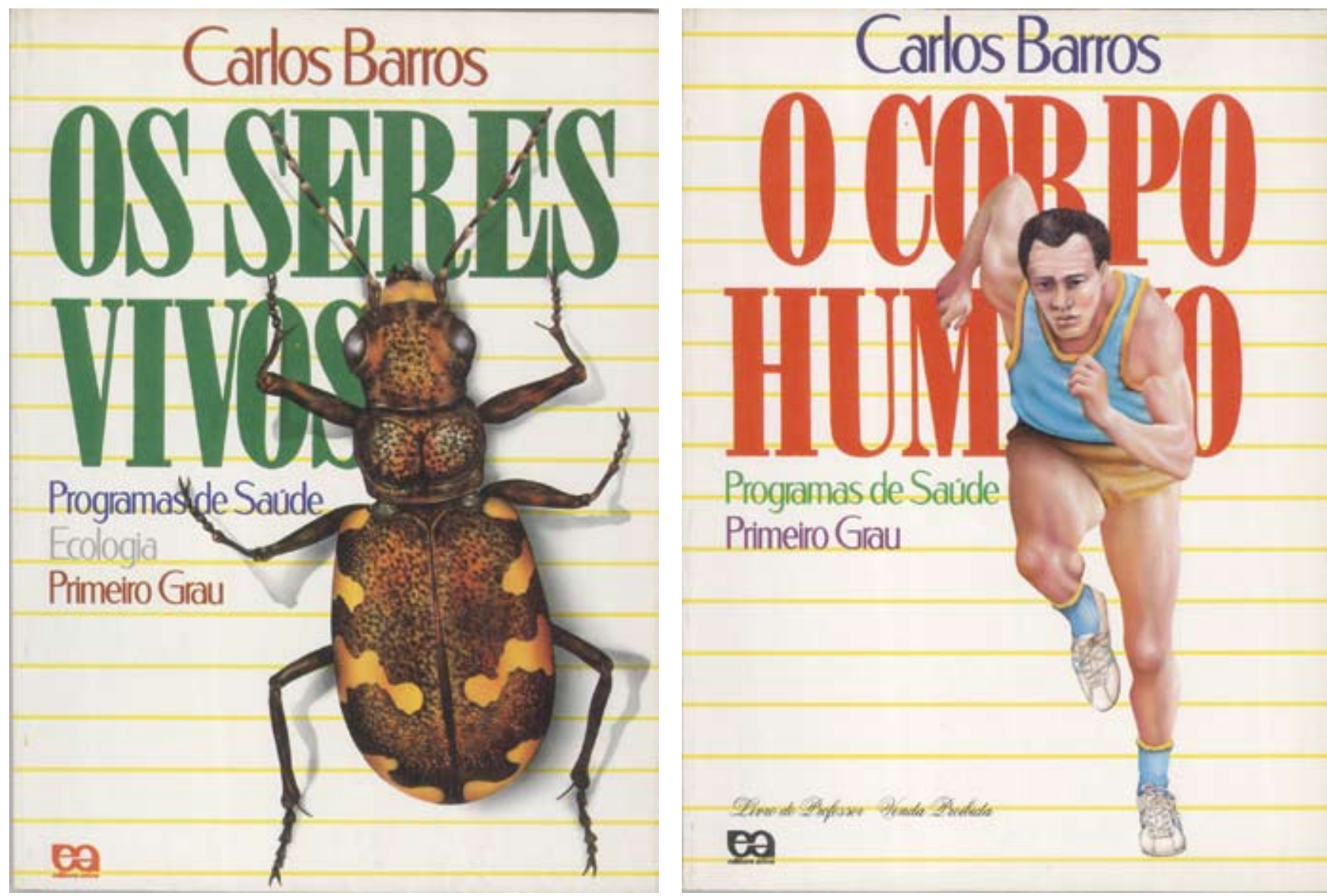

\section{Os seres vivos e $O$ corpo humano - Carlos Barros}

Aqui a ilustração não é a única protagonista, pois o título entra como elemento com que ela interage para formar o design e seu significado. O título não serve só para nomear a obra e a ilustração não entra para traduzir seu significado, mas ambos, letras e imagens, compõem a figura central que particulariza a coleção e cada volume. Ressalte-se que, ao contrário da situação de leitura de um texto em que a falta de letras pode prejudicar a decodificação, o que se coloca aqui é a identidade, a particularização de uma obra pelos meios da linguagem visual, que se dirigem ao sistema cognitivo para criar uma representação internalizada em cada indivíduo a partir da pregnância de uma forma apreendida como totalidade. Assim é que, em revistas de altíssima tiragem, que estudantes e professores conheciam e consumiam, já era comum o procedimento de se cobrir até totalmente o título com retratos de modelos ou personalidades, sem prejuízo para seu reconhecimento pelo público.

Aqui também, o realismo baseado em original fotográico é a linguagem de ilustração utilizada, acrescida do fato de que o escorço do atleta e a sobreposição do inseto ao plano fazem deles não um simples oferecimento à nossa observação externa e neutra, mas de certo modo os trazem a nosso mundo tridimensional, e isso talvez seja o principal fator de atração para esse e tantos projetos produzidos nesse período.
Os seres vivos. Carlos Barros. 34. ed., 1989. Design Ary Normanha. Ilustração Paulo César Pereira. $(27,5 \times 20,2 \mathrm{~cm}$; plastificada). Editor João Guizzo/José Antônio dos Santos.

O corpo humano. Carlos Barros. 27. ed., 1989. Design Ary Normanha. $(27,5 \times 20,2 \mathrm{~cm}$; plastificada). Editor João Guizzo/Wilma Moura. 
História moderna e contemporânea. José Jobson de A. Arruda. 1976. Design Ary Normanha. $(21,7 \times 14,5$ $\mathrm{cm})$.

História moderna e contemporânea. José Jobson de A. Arruda. 24. ed., 1991. Design Ary Normanha. $(21,3 \times 13,7$ $\mathrm{cm})$. Editor Maria Izabel Simões Gonçalves.
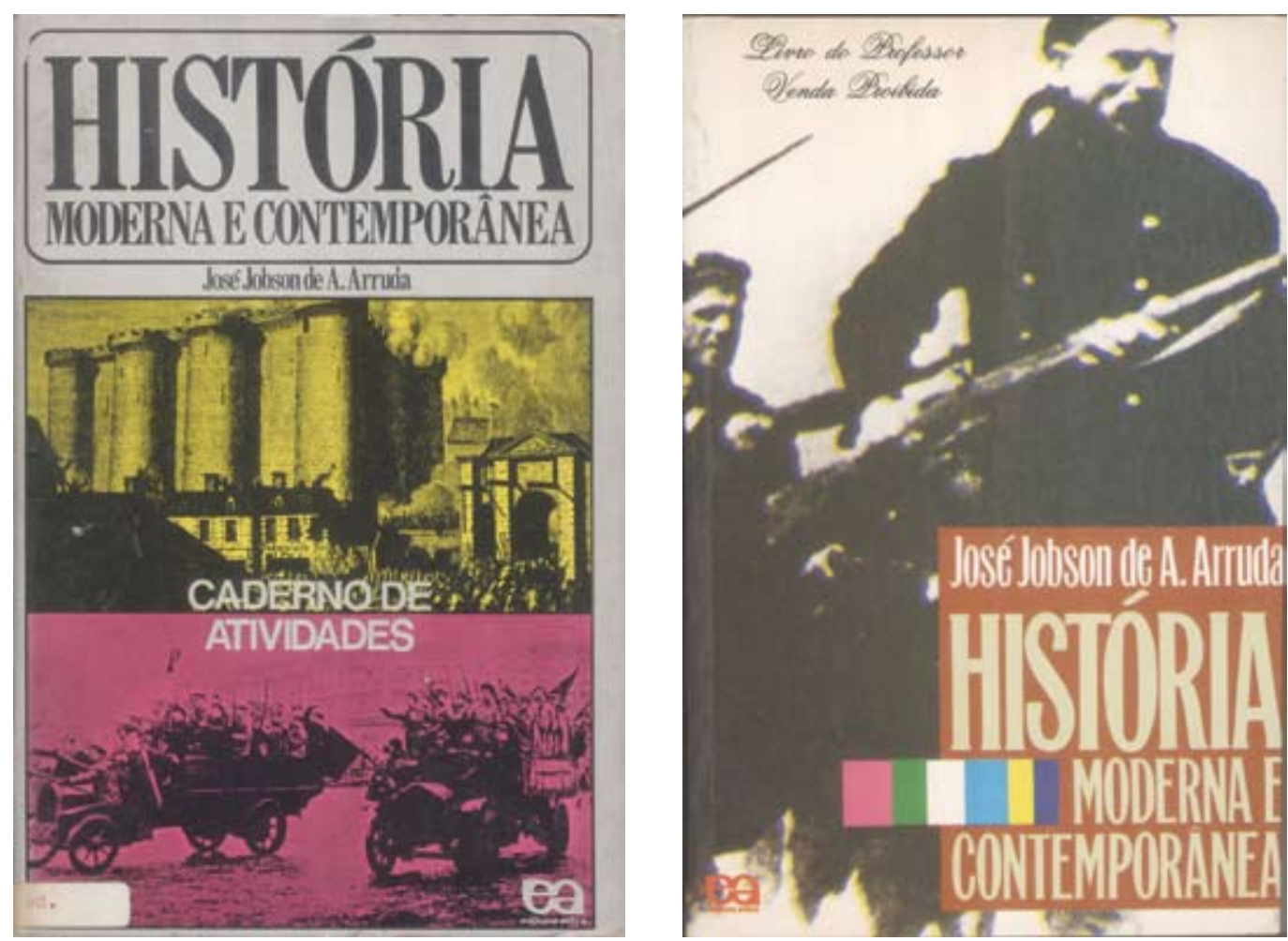

\section{História moderna e contemporânea - José Jobson Arruda}

A fotografia, pelo seu caráter documental, parece ser especialmente destinada a conferir credibilidade e sentido de realidade à representação de disciplinas que tratam de fatos acontecidos, reais, como a História, ou fenômenos do espaço natural e humano, como a Geografia.

Numa das primeiras capas de didáticos de Ary Normanha que antecederam a solução das montagens tridimensionais, a reprodução das imagens da Queda da Bastilha e da Revolução Russa representa os episódios-chave dos períodos segundo a ótica da obra, a da luta social como motor da história. Os dois episódios se relacionam não só tematicamente mas formalmente pelo aspecto de alto contraste fotográfico, e da ação dramática, embora o primeiro seja na verdade uma gravura com intenção documental. A justaposição precisa das imagens, com identidade reforçada pela cor, e do título, formando também um conjunto precisamente composto, dá muita clareza e imediatez comunicativa ao conjunto, conferindo o sentido de objetividade que se acredita perseguido pela disciplina.

A capa da edição de 1991 já não apresenta uma organização simétrica e estática. Há uma ação que se desenvolve, marcada pela direção dos fuzis e dos olhares, que funcionam como vetores indicando um movimento que vem da esquerda e se dirige para fora do campo, contra um inimigo que não vemos mas sabemos que existe. A colocação do título embaixo, à direita acentua esse dinamismo e confere ao sentido de História o de luta e movimento. No caso trata-se de uma fotografia de soldados do Exército Vermelho durante a guerra civil que se seguiu à Revolução Russa para consolidá-la, à qual é atribuída o significado de acontecimento maior da história contemporânea. 


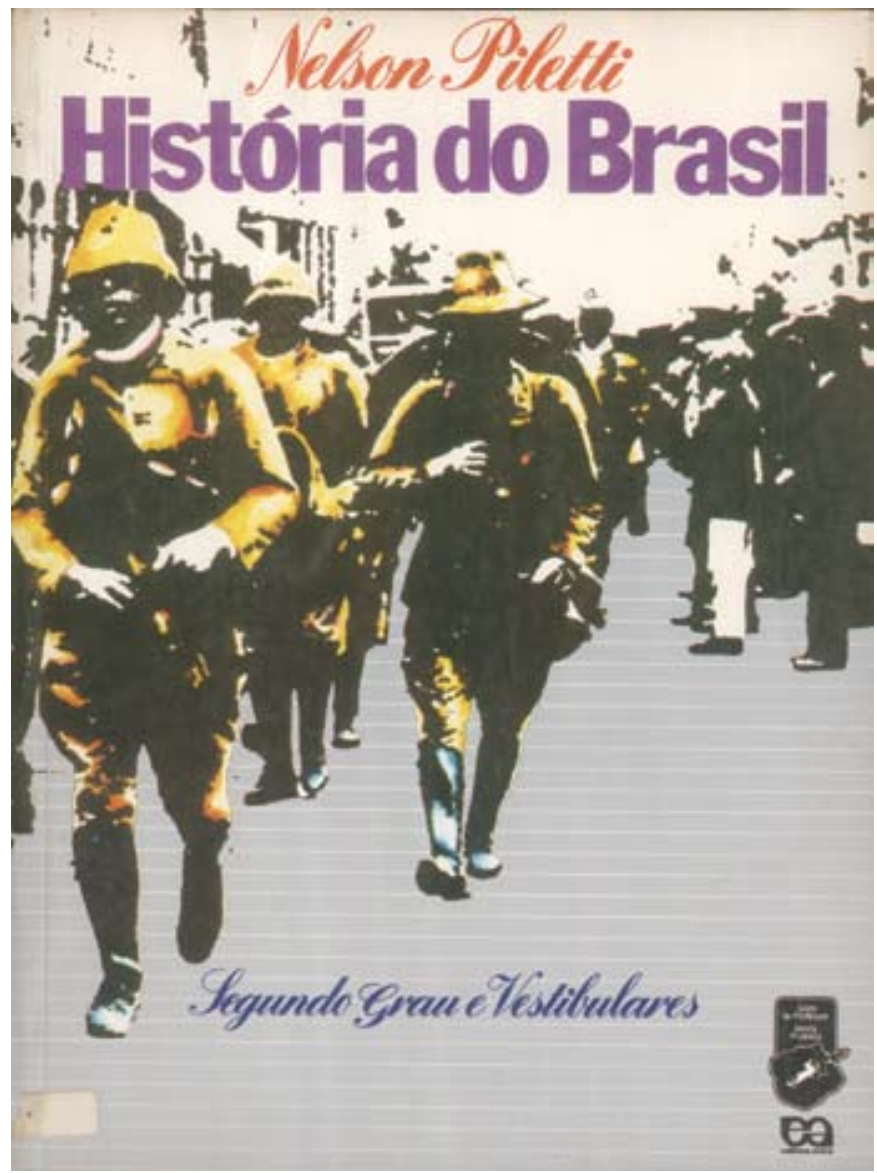

História do Brasil. Nelson Piletti. 2. ed., 1983.

Design Ary Normanha. $(27,4 \times 20,4 \mathrm{~cm})$.

\section{História do Brasil - Segundo Grau e Vestibulares - Nelson Piletti}

Identificada na quarta capa como pertencendo à Revolução de 30, a foto recebe um tratamento que, se não retira totalmente seu aspecto documental, generaliza o sentido do episódio para além do seu marco temporal. O alto contraste dado a imagem retira os detalhes e confere anonimato às pessoas representadas, mas curiosamente não impede algum envolvimento nosso com elas. Isso ocorre, em primeiro lugar, devido às características da perspectiva empregada, com o ponto de fuga localizado nos marcos da imagem conduzindo nosso olhar para dentro dela e criando o chamado ponto de vista subjetivo. Embora socialmente codificadas a partir do sistema de perspectiva criado no Renascimento, as imagens com esse ângulo de visão são percebidas como centradas no observador, dando a aparência de propiciar um ponto de vista único, exclusivo de cada um que as vê. Em segundo lugar, os participantes representados estão em posição frontal a nós, o que também nos aproxima e nos identifica com eles. Se, ao contrário, estivessem posicionados obliquamente, nós os veríamos com mais distanciamento psicológico e objetividade. Por fim, embora não vejamos nenhum olhar, estes estão à altura dos nossos olhos, nem acima, como nos subjugando, nem abaixo, como sendo dominados por nós. O chão, apesar de sem detalhes, ter sido transformado numa superfície puramente gráfica sem indicação de perspectiva, continua parecendo um chão que sai dos limites do quadro da capa e chega a nossos pés, nos incluindo como observadores numa ação histórica não muito determinada, talvez exatamente por isso, a própria História no sentido mais geral e abrangente. 


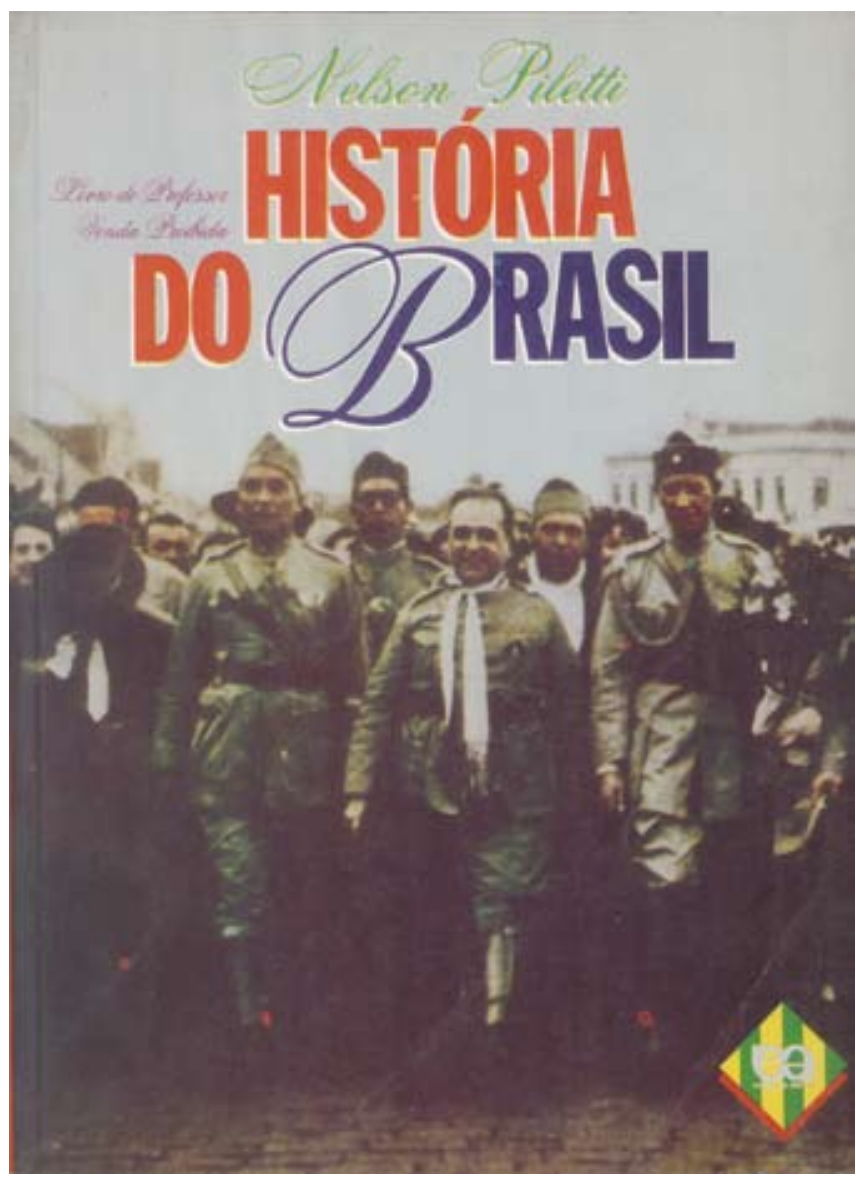

\section{História do Brasil - Nelson Piletti}

Na foto de capa desta edição de 1986, o caráter documental e marcado pelo tempo predomina e nesse sentido nos exclui, embora a resolução do andar dos participantes em nossa direção dê força a imagem e ela seja mais realista, sem intervenções gráficas como a da capa anterior. O olhar dirigido à câmera por alguns participantes, perpetuado na imagem, resulta num olhar dirigido ao visualizador em qualquer tempo, estabelecendo um vínculo mesmo que num nível imaginário, que pode significar desde a busca de uma simples cumplicidade até o chamamento a uma atitude mais drástica. Isto é explorado em imagens conhecidas e é bastante presente na publicidade que nos cerca ou mesmo em capas de revista com modelos nos chamando das bancas e displays. No caso dessa capa, apesar do afastamento dado pelo tempo, a segurança do andar e a direção do olhar dos participantes parecem nos dizer e pedir alguma coisa, embora não saibamos exatamente o que seja.

História do Brasil. Nelson Piletti. 5. ed., 1986. Design Ary Normanha. $(27,5 \times 20,2 \mathrm{~cm}$; plastificada). Editor João Guizzo/Maria Izabel Simões Gonçalves.

\section{História do Brasil - Osvaldo Rodrigues de Souza}

A reprodução da iconografia do período histórico tratado em cada volume era (e ainda é) a solução mais habitual nas coleções da disciplina, mas tende a gerar uma repetição de imagens já bastante conhecidas e retirar a possibilidade de impacto e novidade. Por outro lado, a ilustração original particulariza excessivamente e tem um caráter fantasioso, pois se apoia na imaginação do artista, o que não se mostra convincente para a disciplina. Esta e a capa seguinte são respostas ao problema a partir da combinação de iconografia de época com a intervenção de ilustração.

O volume 2 da obra de Osvaldo de Souza trata do período colonial. A escolha da conhecida gravura de Rugendas, talvez bastasse para mostrar que a vida econômica e social do país se apoiava no trabalho escravo. Mas a reprodução ad infinitum dessa série de gravuras, e mesmo das de Debret, um crítico da escravidão e dos costumes da elite branca do país, esvaziou qualquer possível caráter de denúncia e as transformou em simples documentação de costumes perfeitamente assimilável e transformada numa iconografia oficial do país. O realismo dos grilhões jogados sobre a capa e a imagem de Rugendas com as tonalidades rebaixadas explicitam a denúncia, significam um posicionamento categórico. As correntes são em si um símbolo conhecido da opressão, o que talvez pudesse dar um caráter genérico em demasia, mas a representação hiper-realista, feita a partir de fotografia, com a superfície irregular do ferro, com as partes gastas e oxidadas, atrelam a imagem de negros de verdade subjugados com brutalidade. Além do interesse e fascínio 

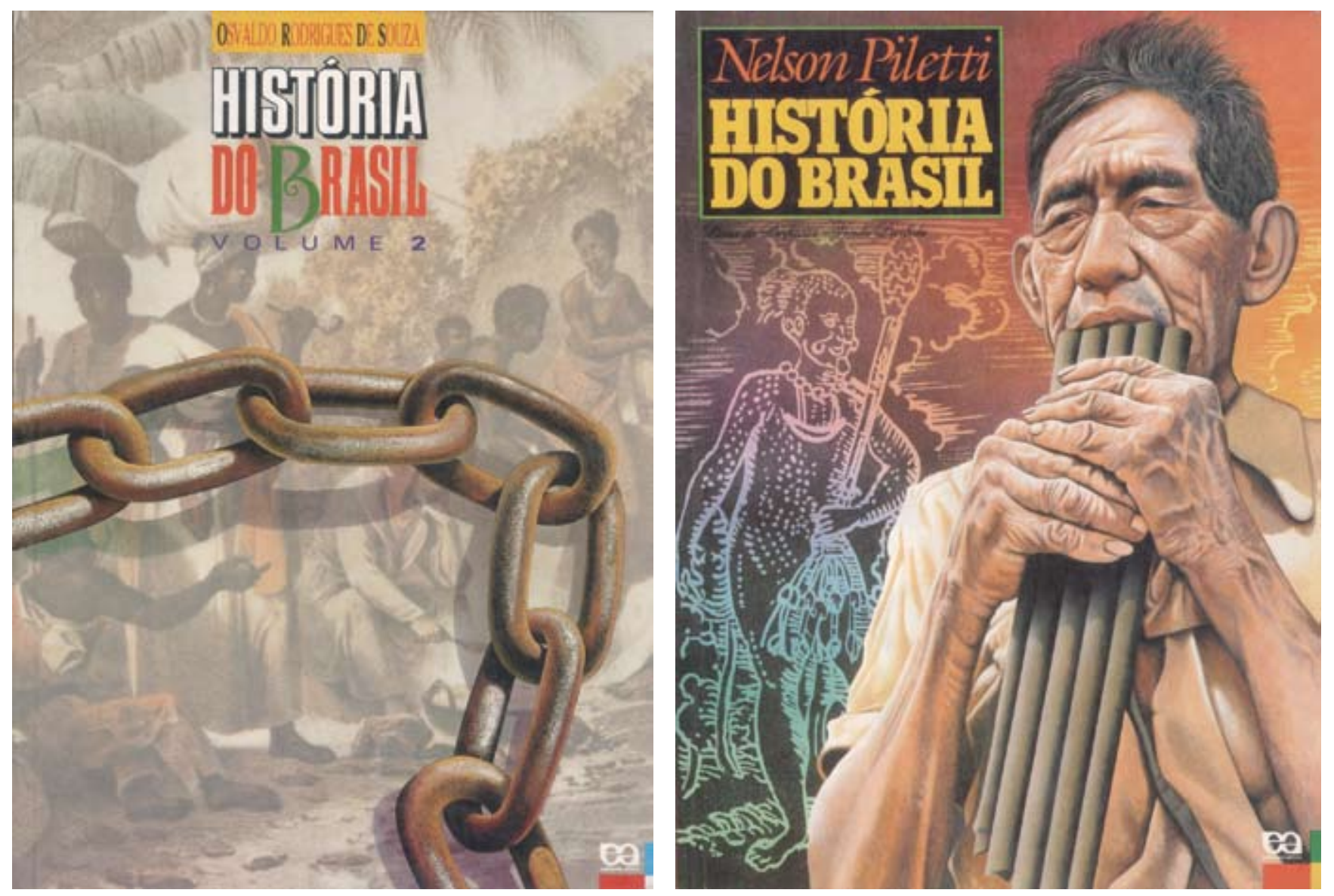

que uma ilustração hiper-realista parece propiciar, como já vimos, será que uma fotografia seria mais eficaz para expressar o mesmo sentido? Aparentemente, presentificaria e impediria uma relação com o contexto temporal real, resultando em sensação de falsidade maior do que a propiciada pela ilustração.

\section{História do Brasil - Nelson Piletti}

A capa da obra de Nelson Piletti também expressa um posicionamento e uma forma de ver a História como feita pelos segmentos populares e não pelos dirigentes da sociedade e da nação, o que corresponde a uma abordagem desenvolvida no contexto da oposição ao regime militar. Há um contraponto entre a imagem de fundo, extraída da obra de Hans Staden e o índio atual. A uma representação feita de traços gerais e em certo sentido anedótica e fantasiosa opõe-se a figura perfeitamente individualizada e digna de um índio de nosso tempo, que absorveu influências dos brancos mas mantém seus costumes e culturas. Há uma ideia de presente e de passado, mas quem está representado nos dois tempos é o habitante original do território, e é por ele que passa a História. A ilustração da obra de Staden, feita originalmente como xilogravura impressa em preto, é invertida sobre fundo colorido para compor e funcionar como suporte para a ilustração de primeiro plano, ou seja, não se trata de apresentá-la como documento, mas de manipulá-la formalmente com vistas a um significado e um efeito plástico que atraia e sensibilize.

História do Brasil. Osvaldo Rodrigues de Souza. 22. ed., 1996. Design Ary Normanha. Ilustração Paulo César Pereira. $(27,5 \times 20,2 \mathrm{~cm}$; plastificada). Editor João Guizzo/José Antônio dos Santos.

História do Brasil. Nelson Piletti. 11. ed., 1990. Design Ary Normanha. Ilustração Paulo César Pereira. $(27,5 \times 20,2 \mathrm{~cm}$; plastificada). Editor João Guizzo/Maria Izabel Simões Gonçalves, Remberto Francisco Kuhnen. 

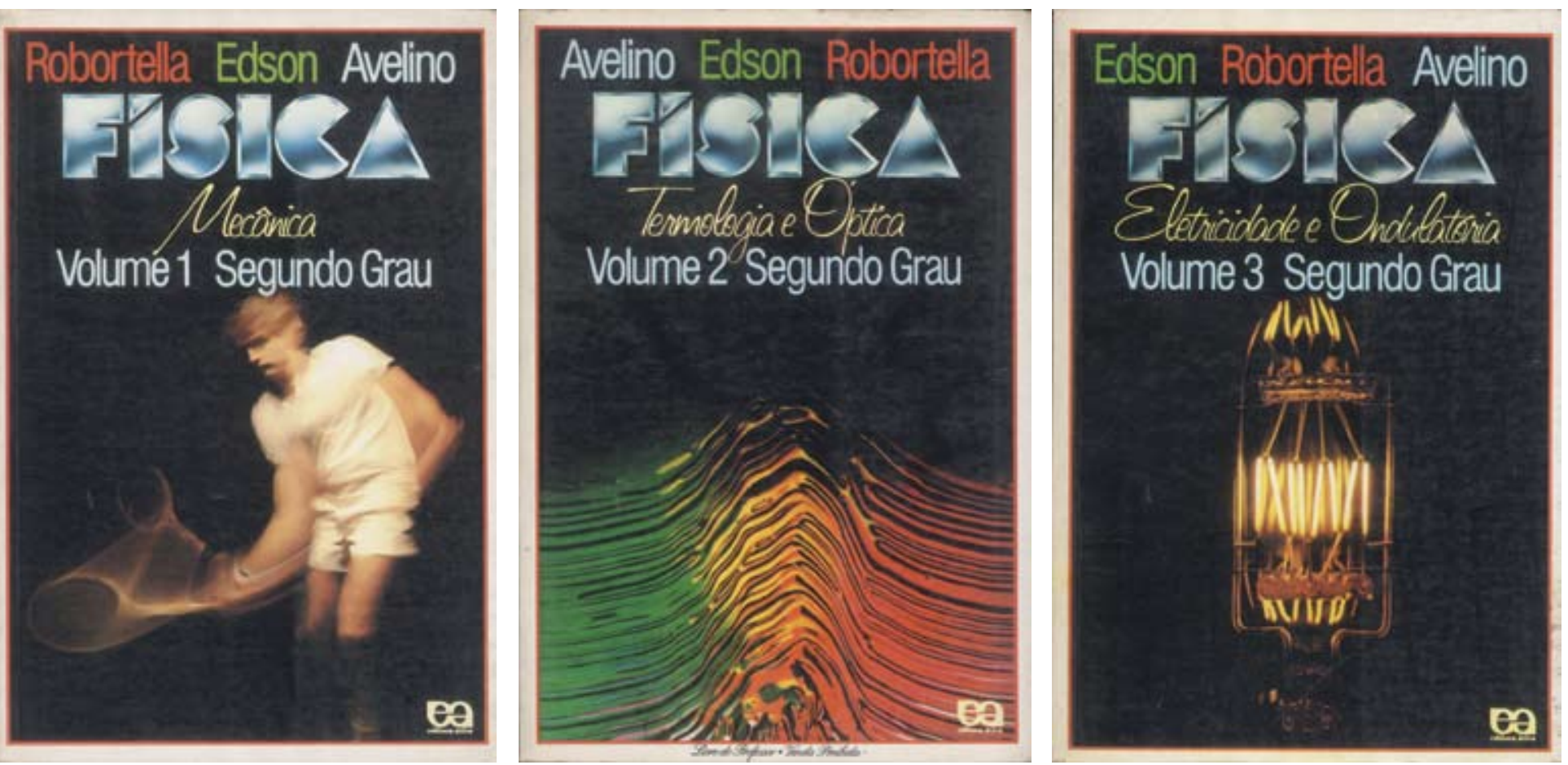

Fisica. 3 volumes. Avelino Alves Filho, Edson Ferreira de Oliveira, José Luís de Campos Robortella. 22. ed., 1984. Design Ary Normanha. $(21,7 \times 14,7$ $\mathrm{cm}$; plastificada).

\section{Física - Robortella, Edson e Avelino}

O realismo fotográfico que aparece nas capas de Português, com a conotação de tecnologia e atualidade encontra plena justificativa em capas de uma disciplina científica para o segundo grau. O título já trata de apresentar essas características, sob a forma de um desenho de letra que simula os efeitos da ação da luz em blocos de cristal precisamente cortados e polidos, que contrasta com a elegância do tipo script do subtítulo. E as fotografias, indiciando o conteúdo da cada volume, completam o caráter científico e high tech a partir de sua precisão técnica.

Mesmo o título tendo forte característica de imagem, localiza-se entre grande número de informações textuais. São quatro linhas que formam um grande bloco que ocupa um terço da capa. Há grande habilidade em conseguir para cada uma dessas informações clareza suficiente, impedindo que elas se percam ou se misturem e que o conjunto fique confuso e sem coesão. Mas essa organização de contrastes, com uso de fontes diversas, cores e dimensões, cria uma imagem ou figura com razoável complexidade, não permitindo que o objeto representado nos dois terços restantes possa ser complexo ou disperso sob o risco de destruir a unidade formal da capa e impedir sua apreensão. Assim, as imagens que ilustram o conteúdo de cada volume são extremamente sintéticas e coesas, no caso do volume 2 e 3, e um pouco menos no caso do volume 1, mais centrífuga mas, ainda assim, unitária.

Como as imagens são fotografias, o fundo escuro comum às três capas não funciona apenas como um plano recuado, mesmo na região superior, para destacar as informações textuais, mas apresenta uma espacialidade. Esta é mais perceptível na capa 1, onde o tenista desenvolve um movimento que a ocupa, mas também na 3, onde envolve a válvula eletrônica. 

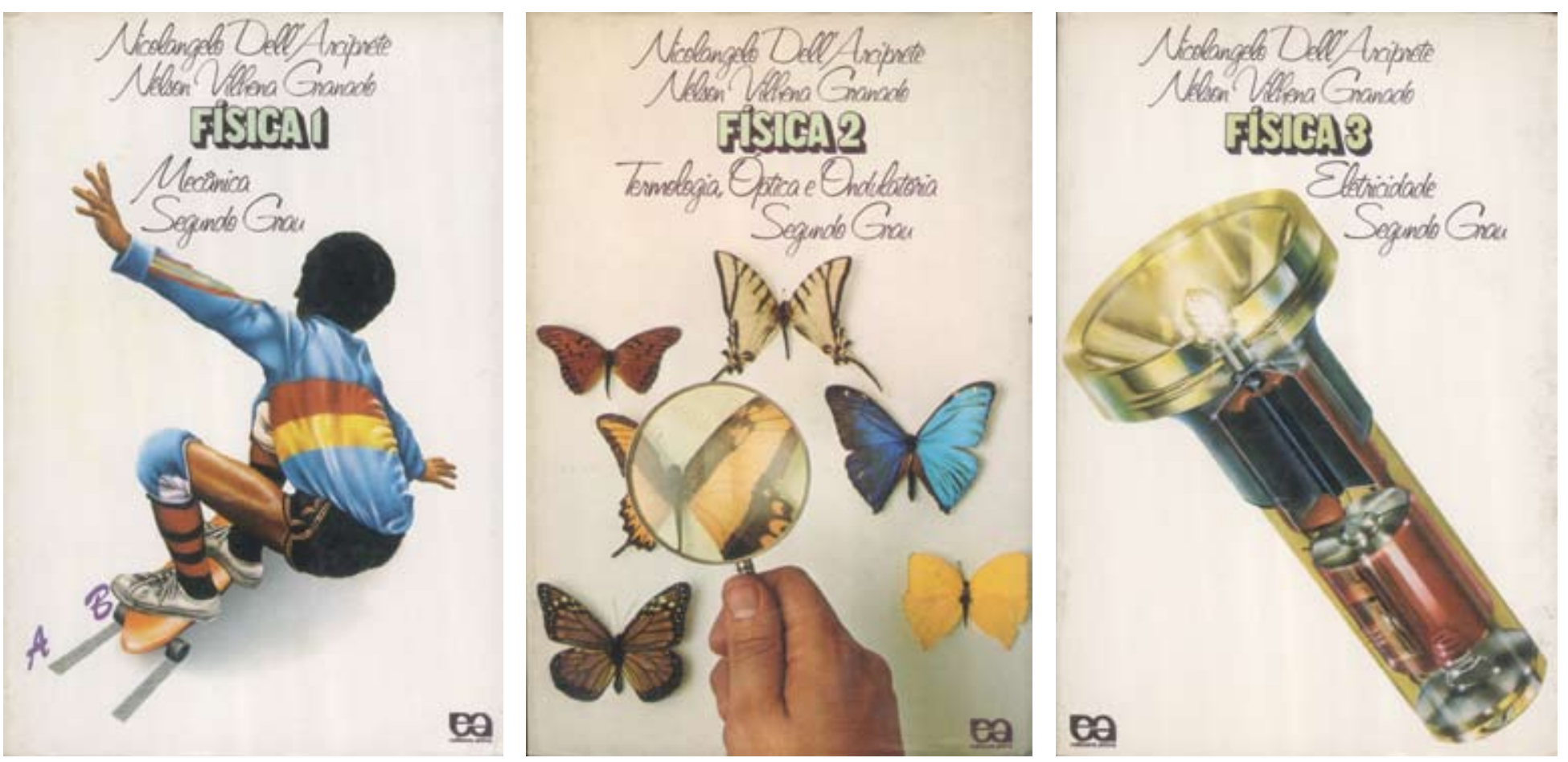

\section{Física - Nicolangelo Dell'Arciprete e Nelson Granado}

O fundo branco, o diagrama e a tipografia comuns às três capas criam um ambiente gráfico de leveza e elegância e permitem que a diversidade de soluções para as imagens, que inclui fotografia e ilustrações, não impeça a identidade da coleção.

As informações textuais de naturezas diversas utilizam duas fontes tipográficas apenas. Autores, conteúdo e nível escolar são todos compostos em tipo script fino e elegante e no mesmo tamanho, formando um grafismo de linhas que resulta em uma mancha vaporosa e leve, com que o título, tridimensional e de pequeno tamanho, contrasta vindo à frente. A volumetria do título relaciona-se com a tridimensionalidade da imagem, e são esses dois elementos que se destacam no campo da capa.

Mesmo havendo fotografia e ilustrações com tratamentos diferentes, como fatores de interesse e variedade, as três imagens têm em comum a exploração do efeito da tridimensionalidade. O volume 2 apresenta uma fotografia, o que em si já garantiria a representação do espaço, mas se busca capturar o efeito do olhar através da lente, revelando a ampliação do objeto visto e a fisicalidade do vidro. $O$ skatista do volume 1 está firme em seu apoio mas se projeta em rápido movimento, preparando seu voo no espaço indefinido e profundo do branco da capa. No volume 3, o espaço manifesta-se no interior do objeto revelado por um efeito de transparência hiper-real de materiais sólidos, ou seja, um hiper-realismo totalmente abstrato e irreal. 
Coleção de Física em 8 volumes. José Luís de Campos Robortella, Avelino Alves Filho,

Edson Ferreira de

Oliveira. 1982 a 1987.

Design Ary Normanha. Ilustrações Paulo César Pereira. $(21,7 \times 14,7 \mathrm{~cm}$; plastificada)
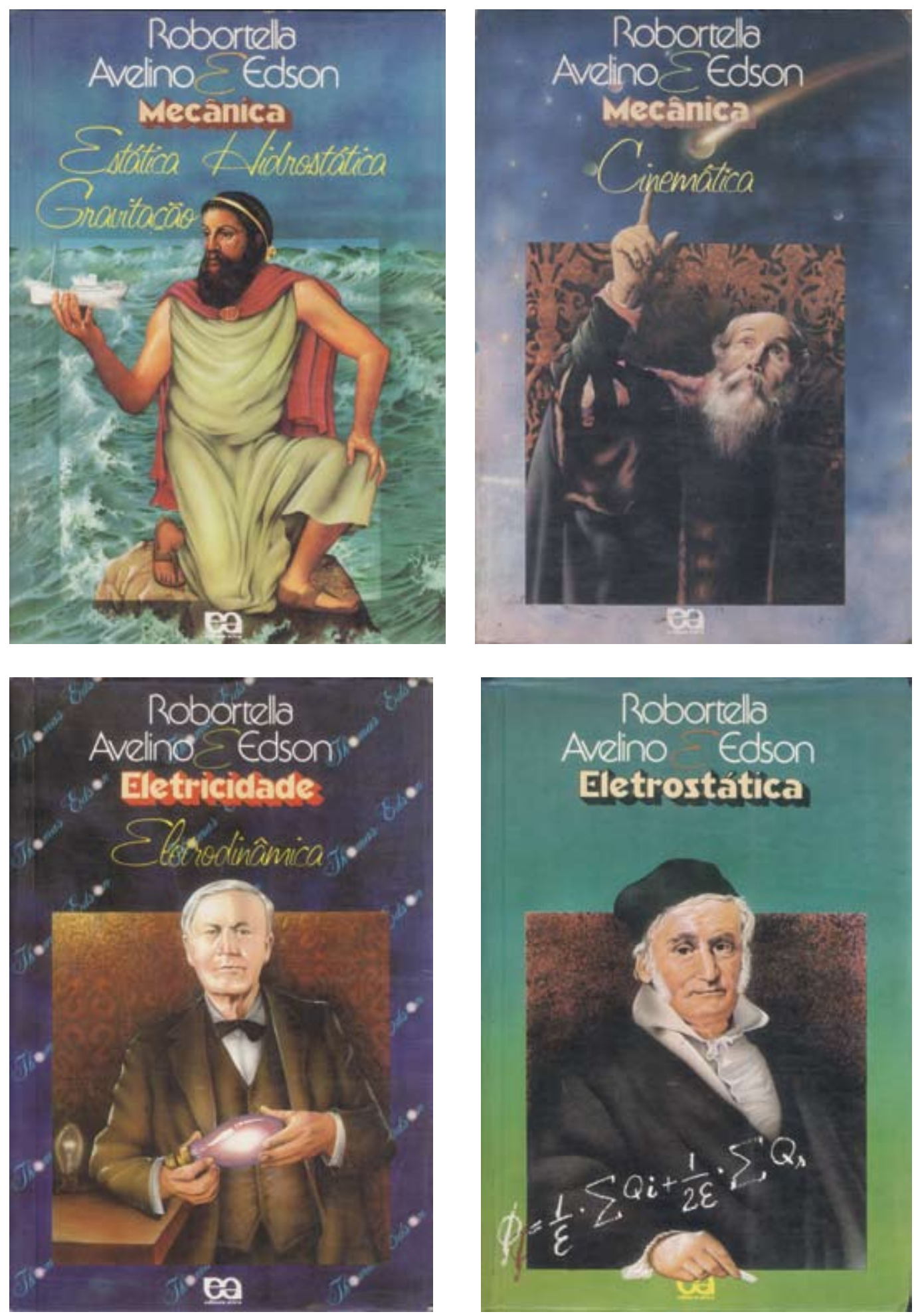

\section{Física - Robortella, Avelino e Edson}

Coleção em oito volumes, apresenta o conteúdo aprofundado das diversas áreas da Física. Assim, cada capa apresenta o retrato do principal cientista relacionado à sua mais importante descoberta ou contribuição, formando uma galeria de notáveis da ciência.

Além da tipografia e desenho da titulagem, existe um diagrama básico comum para a composição de cada capa, que dá a identidade da coleção. Mas este 

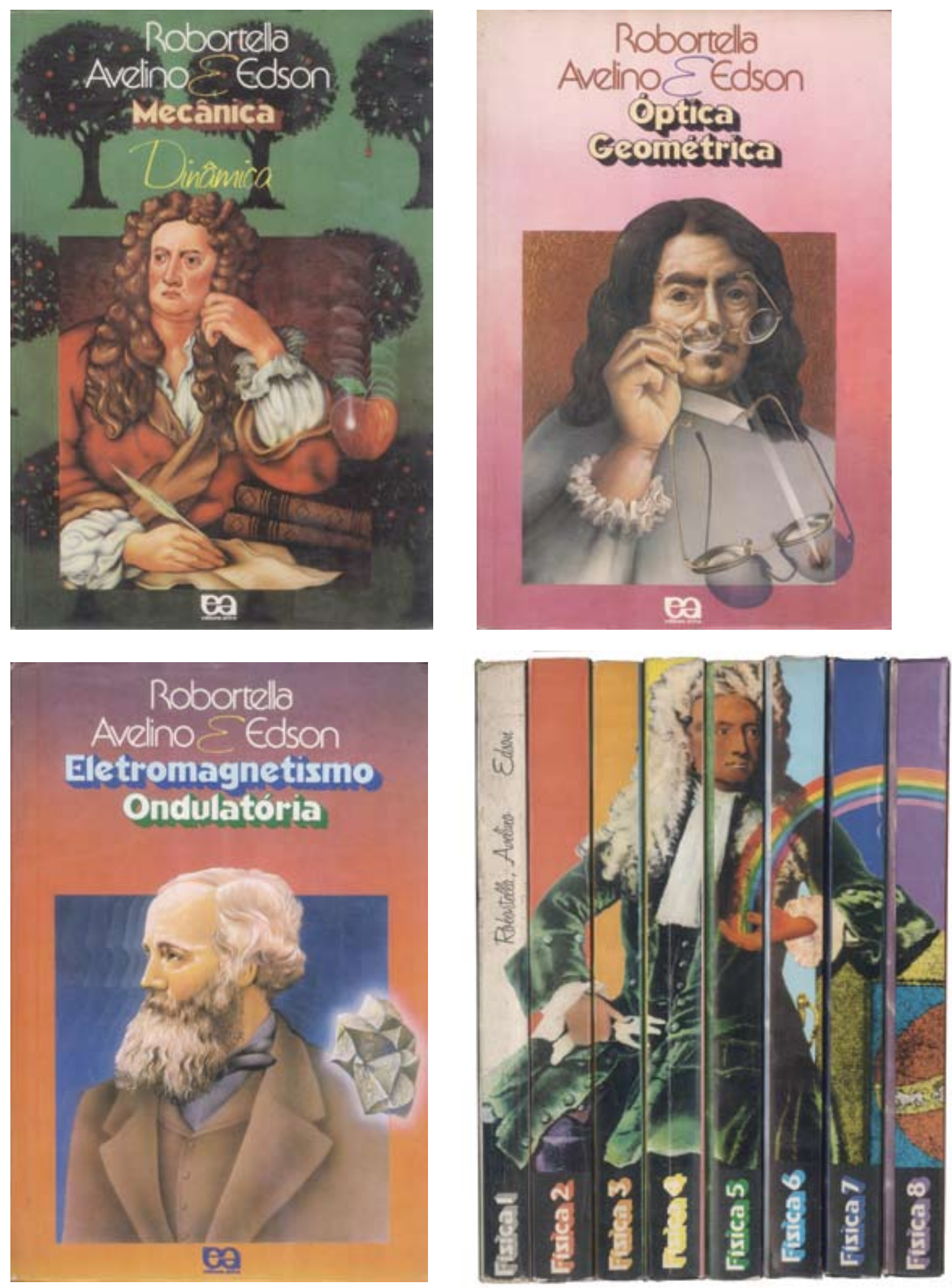

diagrama é "preenchido" de maneira bastante livre, conforme as necessidades compositivas e de tratamento desejado para cada ilustração, executadas todas com maestria por Paulo César Pereira.

Como um "prêmio" para quem completar a coleção, a justaposição ordenada das lombadas formam a figura do criador da mecânica clássica, Isaac Newton. 

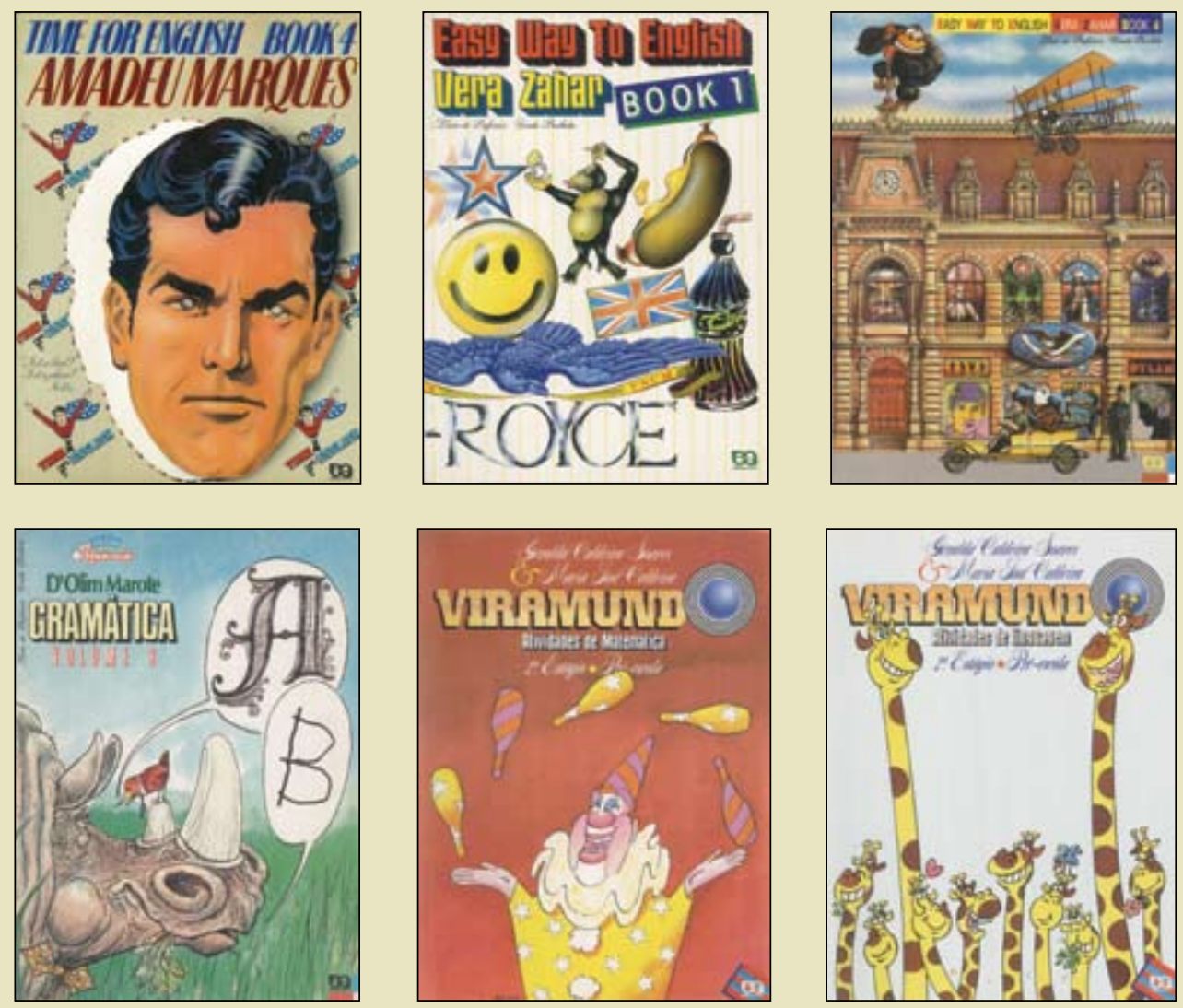

Referindo-se à comicidade e ao desenho de humor, Bergson ressalta que eles promovem um apagamento da sensibilidade, da emoção e um apelo à inteligência e ao cerebral. Mas, o desenho de humor, além do efeito cômico obtido pela quebra ou subversão de expectativa, por exemplo, pode ter qualidades plásticas, como um valor em si e de forte comunicação estética. O resultado final é cativar pela subjetividade, pois objetivamente bastaria a nomeação da obra e uma ilustração "séria" totalmente pertinente ao conteúdo da disciplina.

Assim, o humor é uma possibilidade de atrair a atenção e conquistar o público ao mesmo tempo que identifica e informa. Ao acrescentar diversão, ludicidade e leveza a algo que normalmente é associado a seriedade e sisudez, como o ensino e a escola e os instrumentos didáticos, entre eles o livro, essas soluções de capas procuram criar um terreno de identificação e cumplicidade com os estudantes, procurando seduzi-los emocionalmente pela quebra dessas expectativas.

O humor, e o desenho de humor em particular, está presente nos veículos de comunicação de massas que os estudantes consomem, particularmente as histórias em quadrinhos, e isso propicia a mensagem de que se fala a mesma língua, de que se pertence ao mesmo universo.

A disciplina de língua estrangeira, no caso Inglês, propiciou bem mais liberdade que outras para o viés humorístico das capas. Veículo da cultura de massas 
consumida e até imposta pelo poder econômico e político, particularmente a dirigida aos jovens - a canção popular, os comics, os filmes e séries de televisão, com suas estrelas, ídolos e heróis - a língua inglesa exercia e continua exercendo grande fascínio e motivação para ser estudada. Além disso, fornecia os assuntos a serem explorados pelas capas, exatamente os produtos culturais e seus autores e protagonistas. Assim, a possibilidade de identificação com o público estava dada como em nenhuma outra disciplina. Mesmo havendo um conteúdo formalizado e objetivos de ensino como nas demais disciplinas, esse conteúdo podia ser veiculado se referenciando à cultura de massass. Como os próprios professores eram, e são, formados e em consumidores dessa cultura, não se distinguiriam dos alunos como alvo do design proposto. Talvez seja a isso que Ary Normanha tenha se referido (2008) ao dizer que os professores de Inglês eram os mais abertos e informados para absorver propostas de capa mais ousadas e lúdicas.

Assim, pelo menos uma das capas da primeira edição do Time for English, embora colocada no grupo das de linguagem da fotografia e das montagens, já continha o elemento do humor, que a partir de então caracterizará a maioria das coleções de Inglês.

Outro grupo de capas que apelam para a ilustração um pouco mais descontraída em relação ao conteúdo é o das que se dirigem ao público infantil. Aqui se trata mais de graça e ludicidade mesmo, estratégia utilizada e valorizada pelos próprios professores, motivo pelo qual se constitui a abordagem de design mais empregada nos títulos de educação infantil e nas primeiras séries do ensino fundamental. 

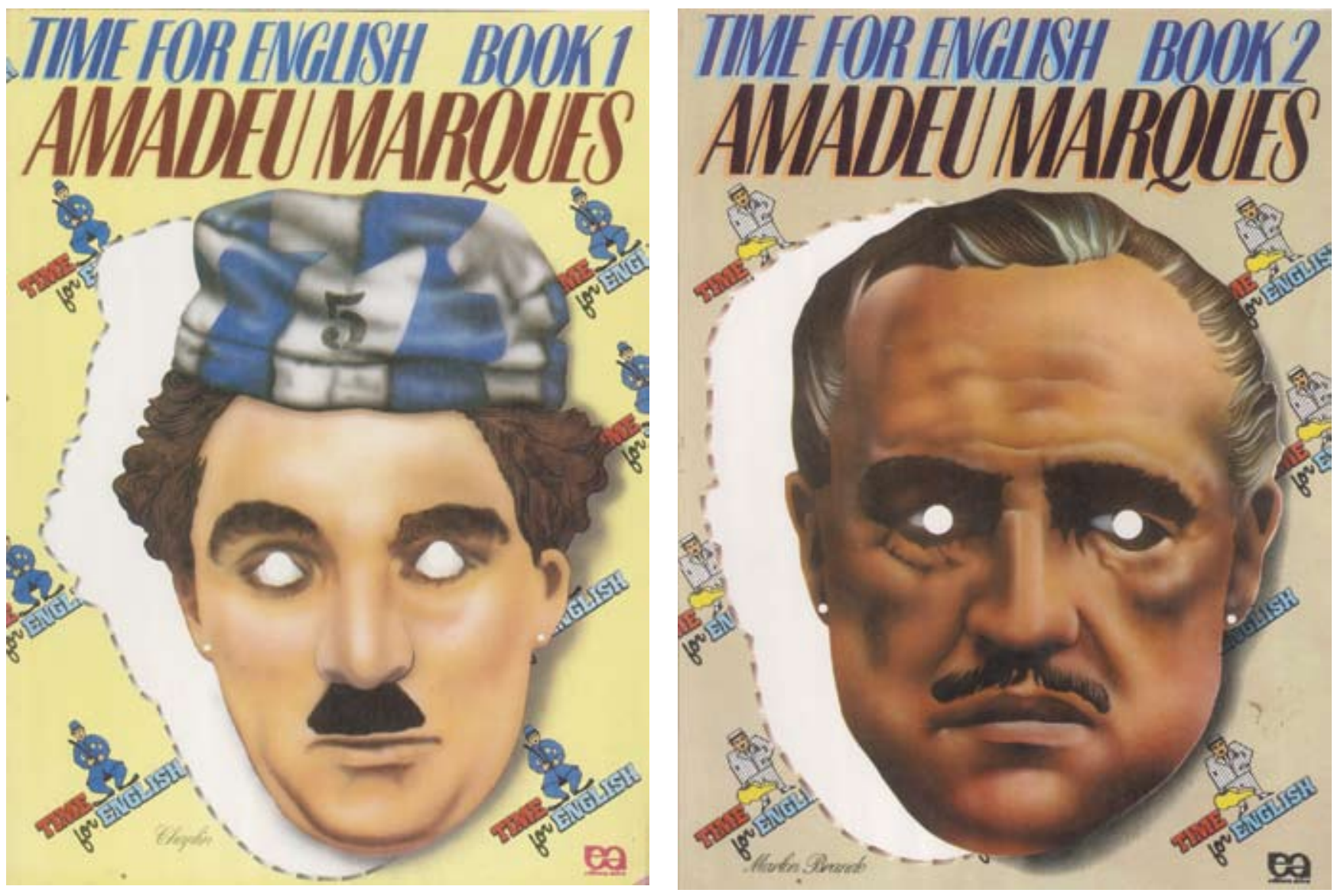

Time for English.

Amadeu Marques. 1988. Design Ary Normanha. Ilustrações Ary Normanha e Paulo César Pereira. $(27,5 \times 20,2 \mathrm{~cm}$; plastificada).

\section{Time for English - Amadeu Marques}

Personagens da história, do cinema e dos quadrinhos da cultura anglo-americana transformados nas conhecidas máscaras de carnaval que, mais que hoje, apareciam nessa época do ano. Uma assimilação à cultura brasileira dos ícones da indústria cultural e da história dos países de língua inglesa. Ironia e humor finos e ao mesmo tempo comunicação imediata com o jovem, quase um convite a se transformarem nesses heróis e brincar.

Os desenhos são executados com aerógrafo e diretamente decalcados de fotografias conhecidas, como no caso de Chaplin presidiário e Marlon Brando como o Poderoso Chefão, ou do famoso retrato de Henrique VIII executado por Hans Holbein. No caso do Super-Homem, a referência é o desenho dos quadrinhos, não os filmes. Assim, não se trata de uma caricatura, pois não há modificação dos retratos originais com exagero dos traços fisionômicos. O humor está na nova situação em que esses rostos conhecidos estão inseridos, com uma correspondente modificação na linguagem de representação, sem se afastar do original conhecido. A simulação do recorte em folha de cartão tracejado remete à forma como muitos materiais para brincadeira eram distribuídos e reforça a referência ao lúdico.

Há o cuidado de identificar os personagens com uma legenda, necessária no caso do talvez ainda não conhecido pelo público estudantil Henrique VIII — embora esse retrato seja o mais reproduzido nos livros de História - e completamente dispensável no caso do inquestionavelmente conhecido e talvez mais admirado 

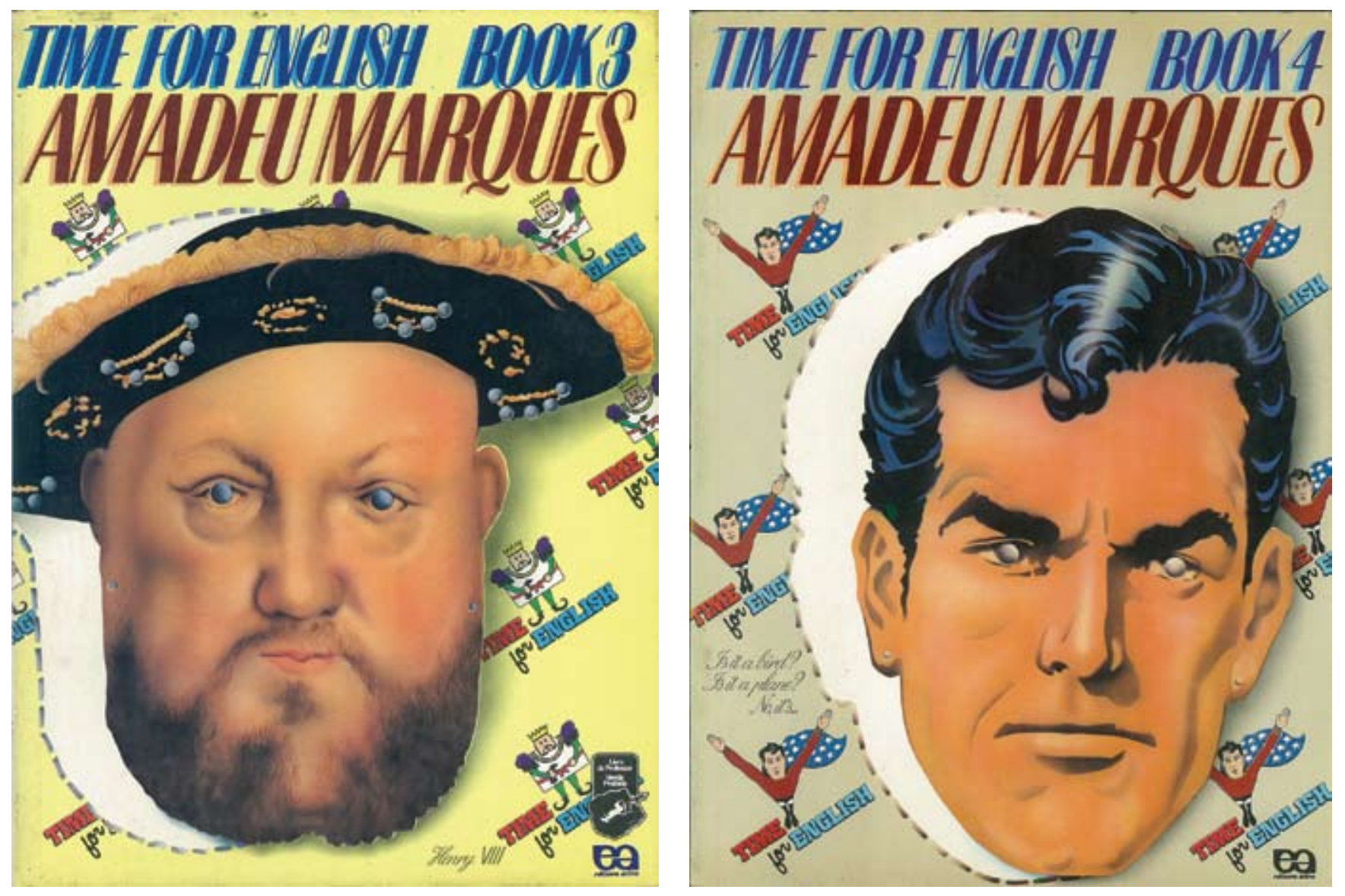

homem de aço, por isso substituída pelo famoso bordão It's a bird? It's a plane? No it's... sem completá-lo.

A identificação da obra — título, volume e autor — aparece concentrada em um único bloco no topo do campo, liberando-o para a maior dimensão possível da máscara. Assim, a estrutura da capa fica muito simplificada, e sua percepção, muito direta. A disposição dos textos em duas linhas, uma para o título e o volume e outra para o autor, em cores diferentes, organiza de forma bastante lógica essas informações e destaca o nome do autor, o que pode se justificar pelo que ele significa como chancela do conteúdo, dado o seu renome. A composição desses textos em caixa alta (maiúsculas) e em fonte estreita sem serifa e italizada confere um sentido de dinamismo ao conjunto.

Por fim, o humor é completado pelas pequenas vinhetas, que associam o título a uma ilustração estilizada e caricatural do personagem, como um logotipo variável da coleção, contextualizado conforme o volume, e criam um padrão de preenchimento do fundo, deixando-o mais rico e interessante.

O sucesso dessas capas pode ser inferido pelo tempo em que ficaram em cartaz, de 1984 até 1994, convivendo com as capas da coleção A new time for English, que, pela lógica, deveria substituir a primeira. 

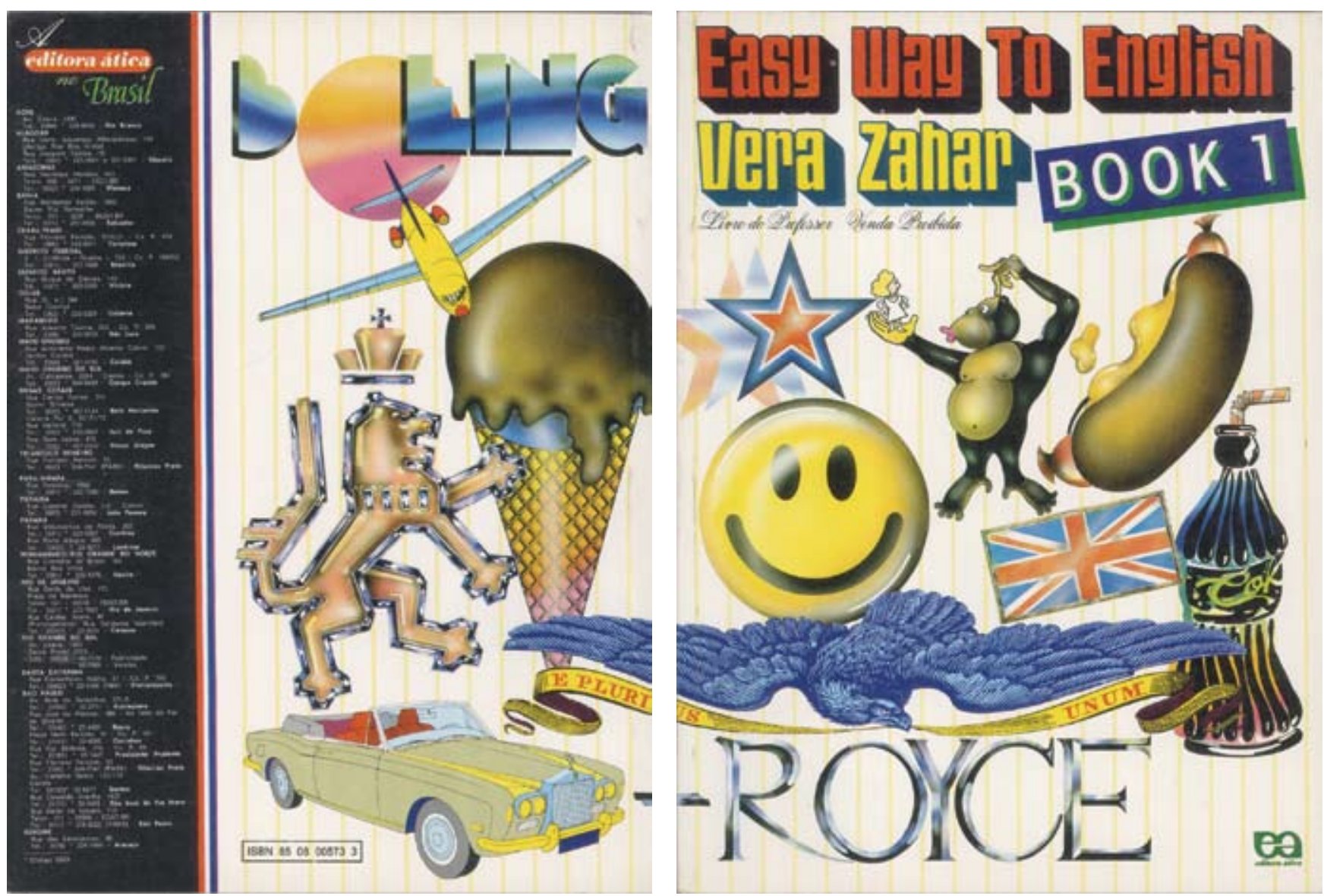

Easy way to English.

Vera Zahar. 1. ed., 1986.

Design e ilustrações Ary

Normanha. $(27,5 \times 20,2$

$\mathrm{cm}$; plastificada). Editor

Avelino Correa.

\section{Easy way to English - Vera Zahar}

As capas desta obra apresentam uma coleção de signos bastante conhecidos da cultura de massas de língua inglesa, justapostos sem qualquer relação causal entre si e sem construir nenhuma história. Cada imagem carrega o seu significado independente do das outras e, mesmo pertencendo a subconjuntos ou universos diferentes na origem, reunidas tornam-se equivalentes como membros da cultura estudada pela disciplina e como de fato são recebidas e "deglutidas". O fundo gráfico uniforme contribui para esse efeito, descontextualizando-as e equiparando-as.

A liberdade com que esses signos aparecem e a inexistência de uma história são reforçadas pela ausência de escala entre os objetos e seres e pelo arranjo dinâmico, não simétrico entre eles. Há um equilíbrio na composição, não pela disposição das formas em relação a algum eixo ou grade, mas com elas se encaixando e compensando suas massass de maneira mais livre. Assim, o fator principal de atração não reside nas referências em si, todas elas conhecidas do público, mas principalmente na forma como são tratadas e apresentadas, com os efeitos de tridimensionalidade, as cores e os reflexos das ilustrações pop, para agradar e divertir.

Os textos de título e autoria são compostos em fonte que forma blocos também com efeito tridimensional, mas sua regularidade e geometria contrasta com as formas mais livres das ilustrações. No entanto, o afastamento mais acentuado entre as palavras torna-as blocos, figuras com um certo isolamento que se integram à composição, à semelhança das outras. 

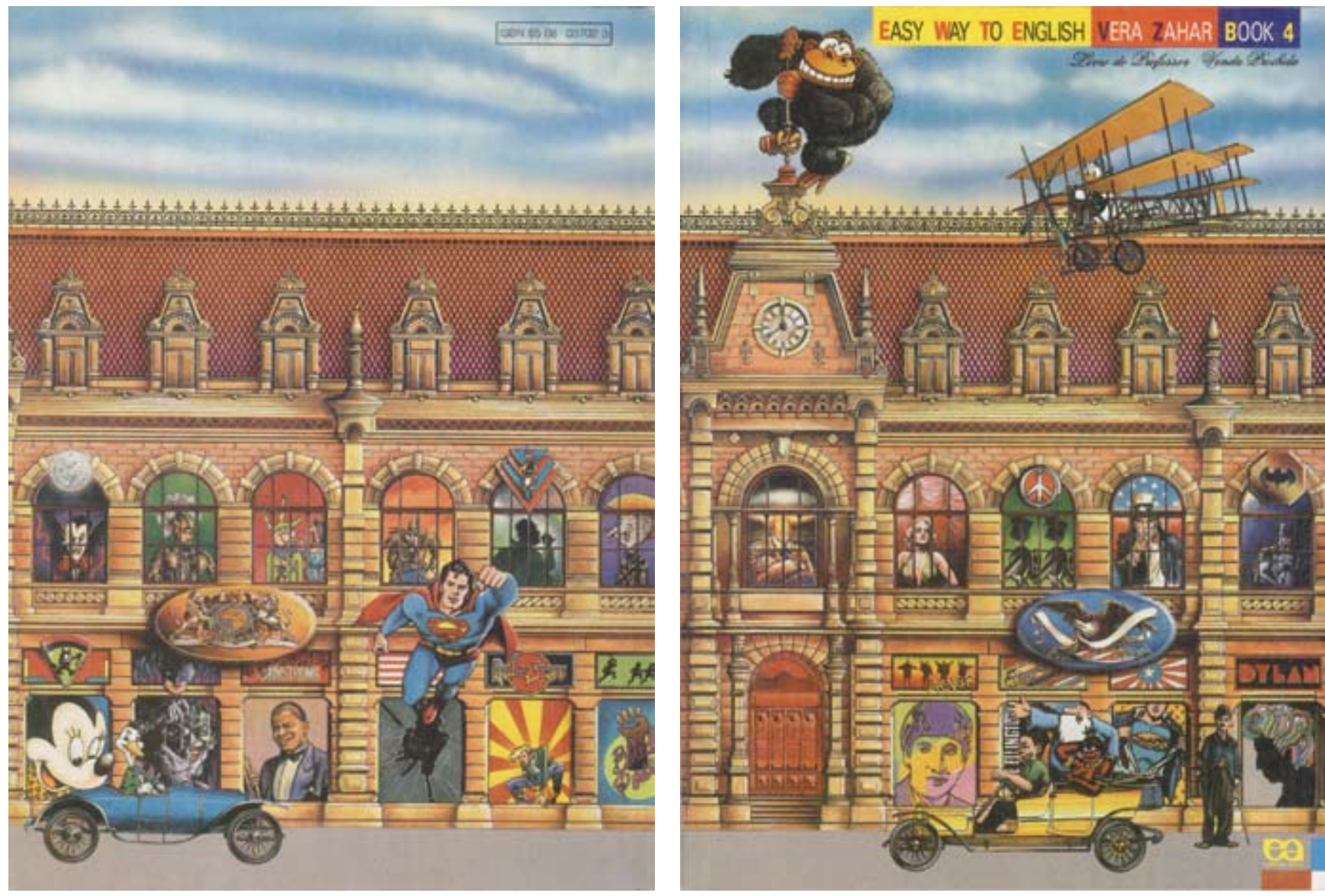

\section{Easy way to English - Vera Zahar}

A nova edição apresenta um desenho extremamente detalhado de uma cena de rua e uma mansão vitoriana que vai da primeira à quarta capa, onde se distribuem inúmeros personagens da cultura de massas inglesa e norte-americana. A elaboração com riqueza de detalhes convida o leitor a procurá-los e reconhecê-los, jogo que vai prosseguir nos outros volumes, pois alguns deles são trocados e aparecem em lugares diferentes. $O$ desenho da mansão estrutura e organiza formalmente uma colagem de figuras elaboradas em linguagens e técnicas diferentes, por diversos ilustradores, o que dá maior riqueza ao conjunto, sem quebrá-lo.

A imagem é de tal forma particular e original que cria uma identidade inquestionável para a obra, podendo ser dominante a ponto de reduzir a área para as informações textuais sem prejudicar o reconhecimento. Assim, título, autoria e volume aparecem relativamente pequenos, embora bem destacados pela região do campo que ocupam, e diferenciados pelas cores primárias aplicadas a cada grupo de informações. Dessa forma, a ideia de que título e nome de autor devem ser necessariamente grandes e aparecer bem para serem lidos e assim garantir a identidade de uma obra é contradita eloquentemente. O estímulo visual e os significados a ele associados se realizam primeiro do que a nomeação linguística e constituem a estratégia mais poderosa e adequada para a criação de identidade e para a comunicação em uma capa. Uma vez gravada como imagem, a lembrança se sedimenta e todas as associações verbais desejadas ocorrem simultaneamente.
Easy way to English. Vera Zahar. 2. ed., 1991. Design Ary Normanha. llustrações Ary Normanha, Cecília Iwashita, Fukuko Saito, Jayme Leão, Antonio U. Domiencio. $(27,5 \times 20,2$ $\mathrm{cm}$; plastificada). Editor Sandra Almeida. 

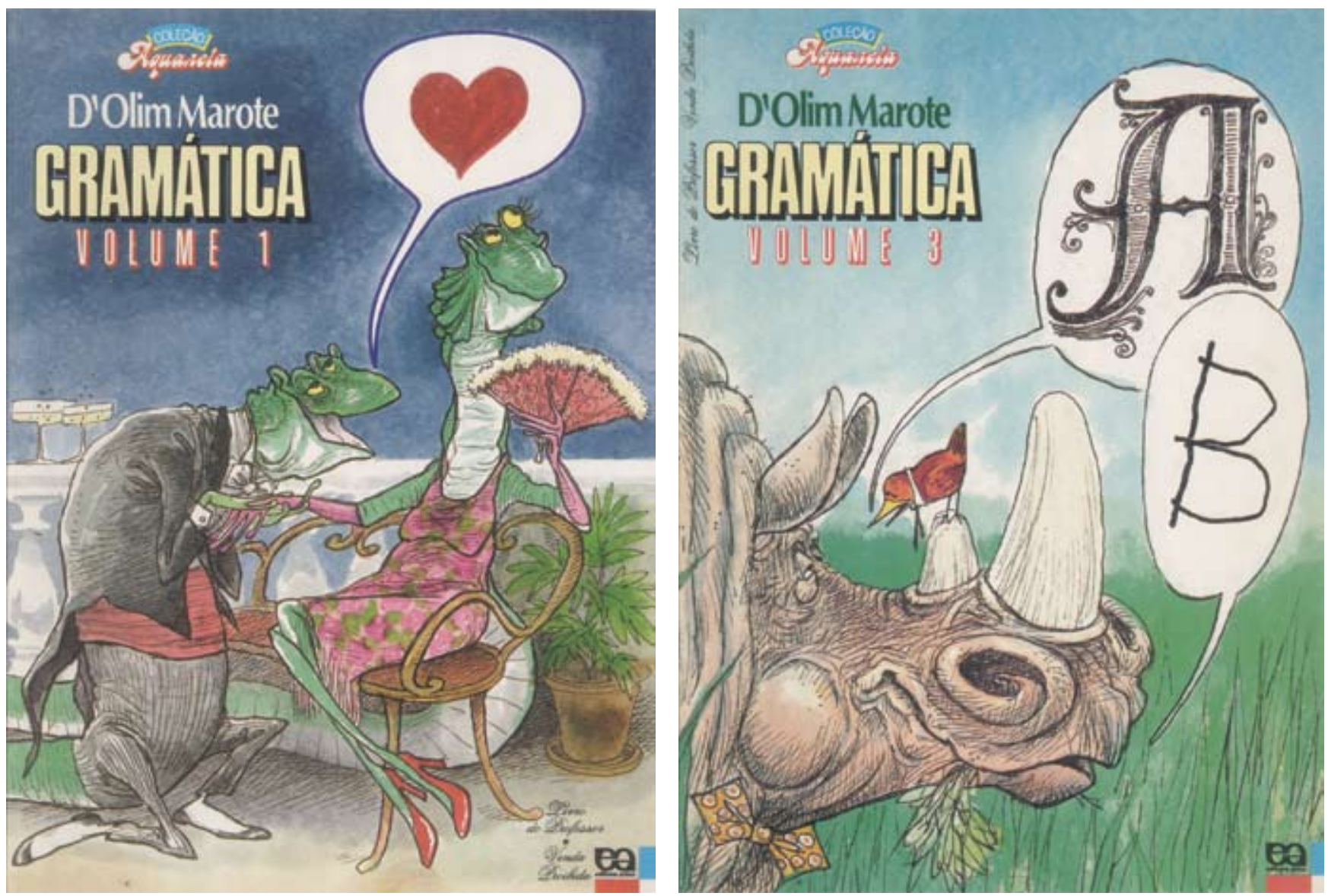

Coleção Aquarela: Gramática. D'Olim Marote. 1993. Design Ary Normanha. llustração Roberto Negreiros. $(27,5 \times 20,2$ $\mathrm{cm}$; plastificada). Editor João Guizzo/Wilma Moura.

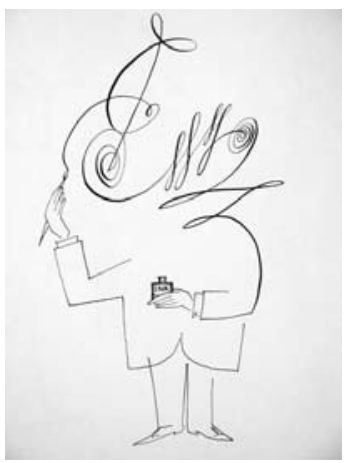

16 Cartunista romeno naturalizado norte-americano (1914-1999), teve seu trabalho mais conhecido divulgado pela revista New Yorker.

\section{Coleção Aquarela: Gramática - D’Olim Marote}

Aqui o cartum mostra o seu potencial comunicativo e desafiador à inteligência. Desenvolvidos para capas de livros dirigidos a crianças dos 7 aos 10 anos, evidentemente se apoiam no universo das histórias infantis e seus animais antropomorfizados e apresentam riqueza de detalhes, de colorido maior do que grande parte dos cartuns dirigidos a adultos e veiculados em outros contextos.

Mas à parte as qualidades voltadas para agradar esteticamente o público infantil, veiculam significados relacionados ao assunto da disciplina e da comunicação humana em geral e reconhecem e se apoiam na inteligência ativa das crianças. Como marca de interpretação do título e do assunto da coleção, e, ao mesmo tempo de identidade, todas possuem um balão de fala e em seu conteúdo, isto é, no código de comunicação que eles expressam, concentram o significado do uso da gramática. Mas já na primeira delas o signo não é linguístico, o que estende a significação de código e linguagem para além da língua falada e escrita. Na segunda capa, de inspiração clara no humor sofisticado de Saul Steinberg ${ }^{\mathbf{1 6}}$, a aposta na inteligência da criança para decodificar e interpretar uma proposição metalinguística é digna de nota e revela o respeito por ela como ser capaz de concretizar sentidos quando adequadamente estimuladas.

A ilustração extravasa a capa e, na quarta, capa completa o sentido provocado pelas expressões dos personagens e pela situação comunicada na primeira capa. 

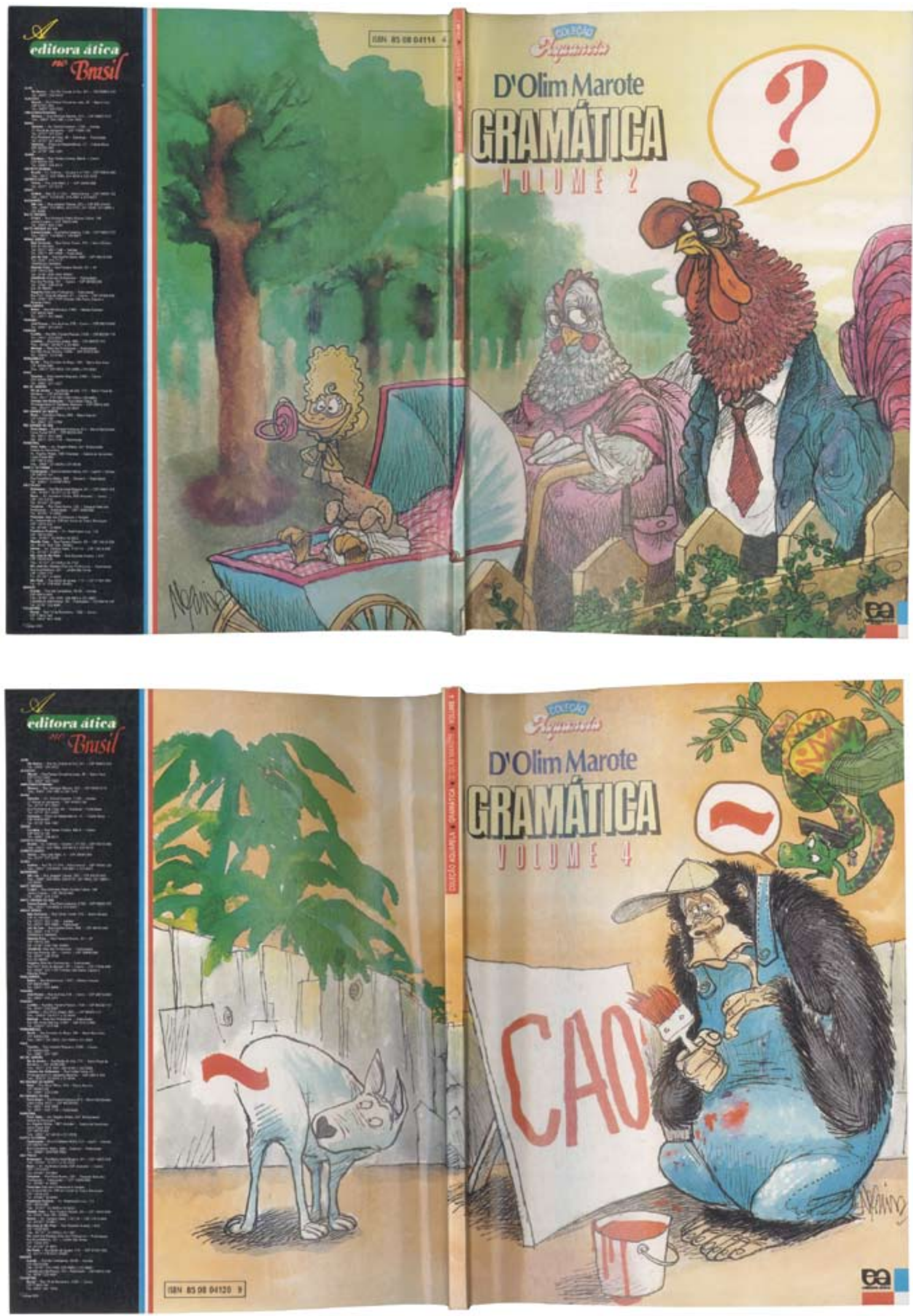

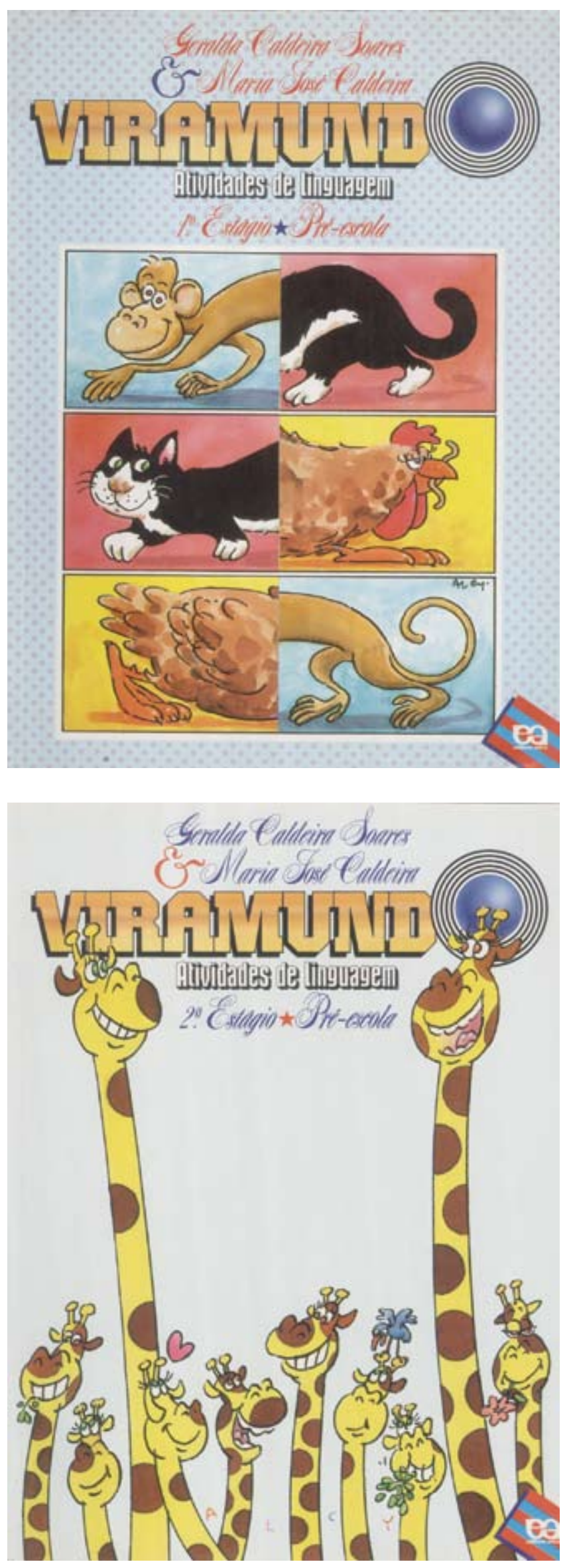

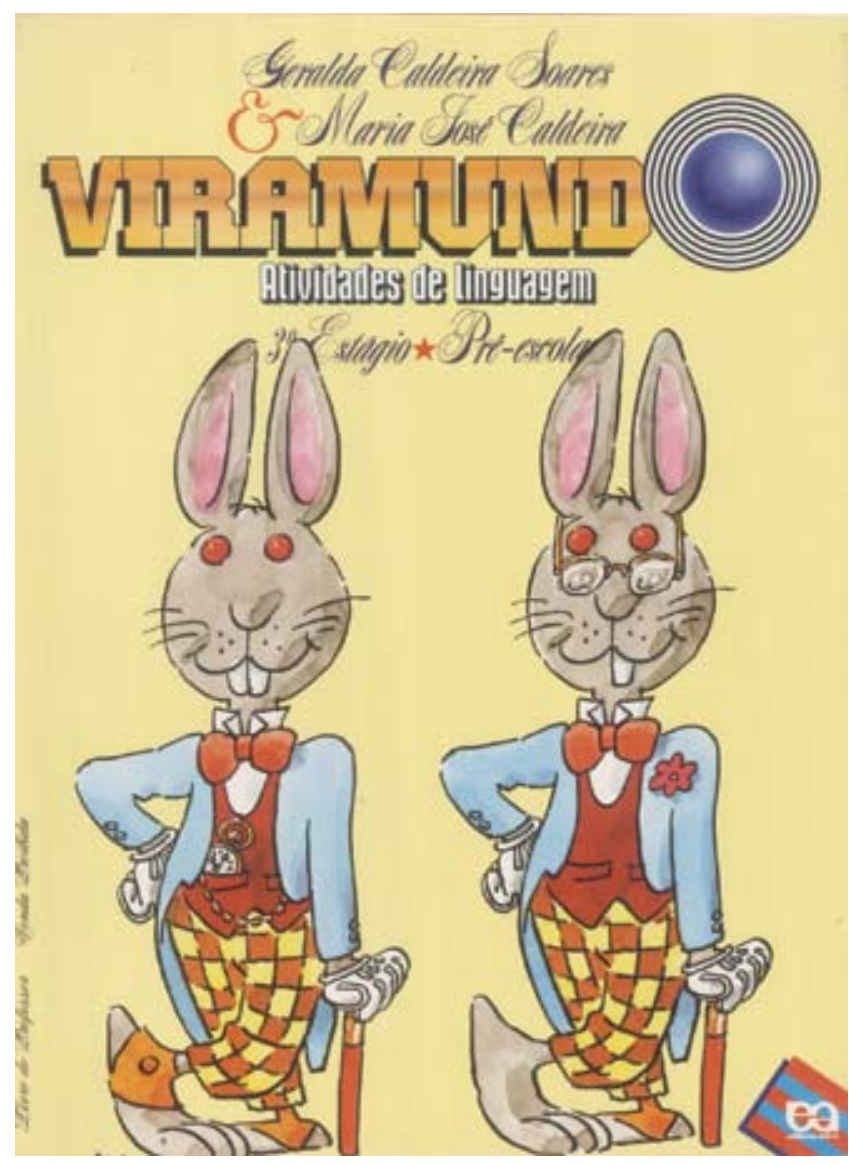

\section{Viramundo: Atividades de linguagem - Geralda C. Soares e Maria José Caldeira}

Voltadas para a pré-escola, essas capas são essencialmente lúdicas, propondo jogos e diversão inteligente, sem precisar passar pela verbalização e escrita para serem compreendidas. Como em todo cartum com qualidades plásticas e que porta uma linguagem e uma interpretação pessoal, o humor da situação não pode ser isolado do humor contido pelo próprio traço e colorido. A informalidade e irregularidade do traço e do preenchimento das superfícies com cores e manchas são elementos expressivos, que, junto com a forma particular com que o cartunista representa e dá vida a seres e objetos que encontramos no mundo real ou já representado por outros, constroem essa imagem capaz de divertir e deleitar.

Embora a ilustração seja dominante, o que é usual na grande maioria de designs dirigidos ao público infantil, deve-se notar que o título da coleção

Viramundo: Atividades de linguagem. Geralda Caldeira Soares, Maria José Caldeira. 1990. Design Ary Normanha. Ilustração Alcy Linares. (27,5 x 20,2 cm; plastificada). Editor João Guizzo/Wilma Moura. 


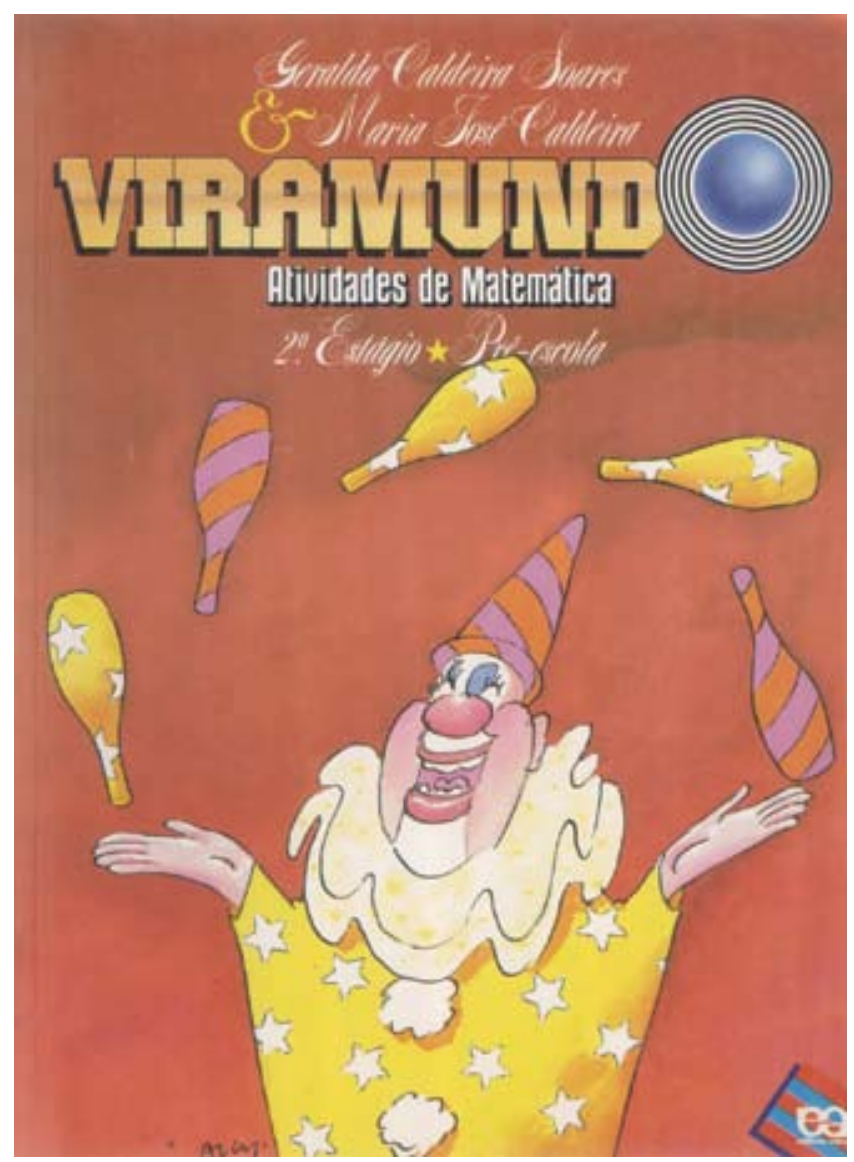

também é explorado como imagem, tanto pelo desenho particular e pelo sombreado das letras como pelo recurso de substituir uma delas por uma figura, o que também dá um caráter de brincadeira ao próprio título. As demais informações textuais, com suas particularidades de desenho, também organizam uma forma, nucleada pelo título, também rica em contrastes e que, junto com a linguagem das ilustrações, constrói a identidade visual da coleção.

\section{Viramundo: Atividades de Matemática - Geralda C. Soares e Maria José Caldeira}

Aqui, conteúdos evidentes da disciplina são explorados como ilustrações lúdicas cuja decodificação também prescinde da verbalização. Noções de conjunto, semelhanças e diferenças, paralelismo e outras são o material para a criação de imagens sugestivas e cativantes que visam antes de tudo agradar esteticamente e divertir.
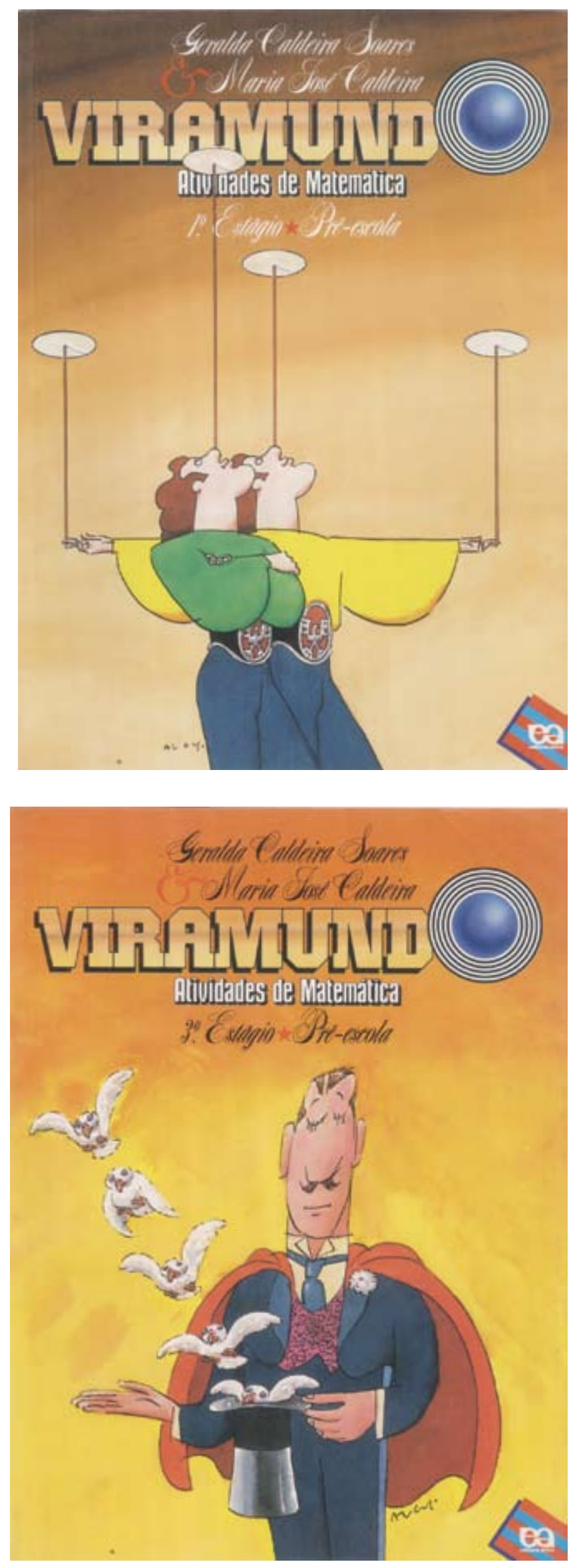

Viramundo: Atividades de Matemática. Geralda Caldeira Soares, Maria José Caldeira. 1990. Design Ary Normanha. Ilustração Alcy Linares. (27,5×20,2 cm; plastificada). Editor João Guizzo/Wilma Moura. 


\subsection{A tipografia nas capas da Ática}
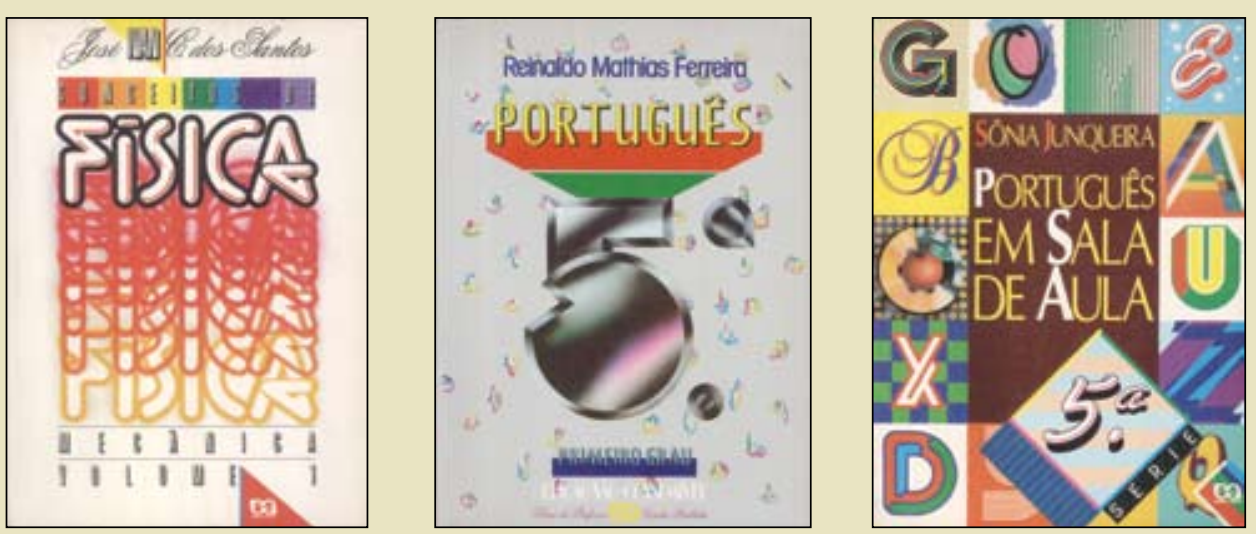

Mesmo nas capas ilustradas ou com fotografias que vimos, as informações textuais são tratadas como imagem, para serem vistas antes de lidas e propiciarem reconhecimento e identidade pela forma, não pela leitura. Ainda que em capas essencialmente fotográficas ou ilustradas, a letra, tratada como imagem, era valorizada em sua integração com os elementos propriamente pictoriais. E pudemos ver diversos exemplos de combinação apurada entre fontes de desenhos diversos na composição de títulos e demais informações textuais.

Ou seja, não se trata de uma relação entre texto e imagem como encontramos numa página interna, onde um complementa o outro dando a chave de leitura para a compreensão de um raciocínio. Textos são tratados como formas que interagem com outras formas, que são as imagens, sob as regras não da gramática mas sim da linguagem visual.

Assim, num conjunto de capas em número bem menor que as ilustradas e fotográficas, e produzidas em período mais recente, Ary Normanha pôde trabalhar com a associação de fontes tipográficas diferentes e contrastantes numa composição unitária executada com virtuosismo, buscando efeitos plásticos que prescindiam do uso de imagens referenciais.

Embora algumas ultrapassassem o período fixado para a pesquisa, suas características aprofundam o que aparece nas capas analisadas e sua qualidade e abordagem inovadora para livros didáticos justificam sua presença neste trabalho. 


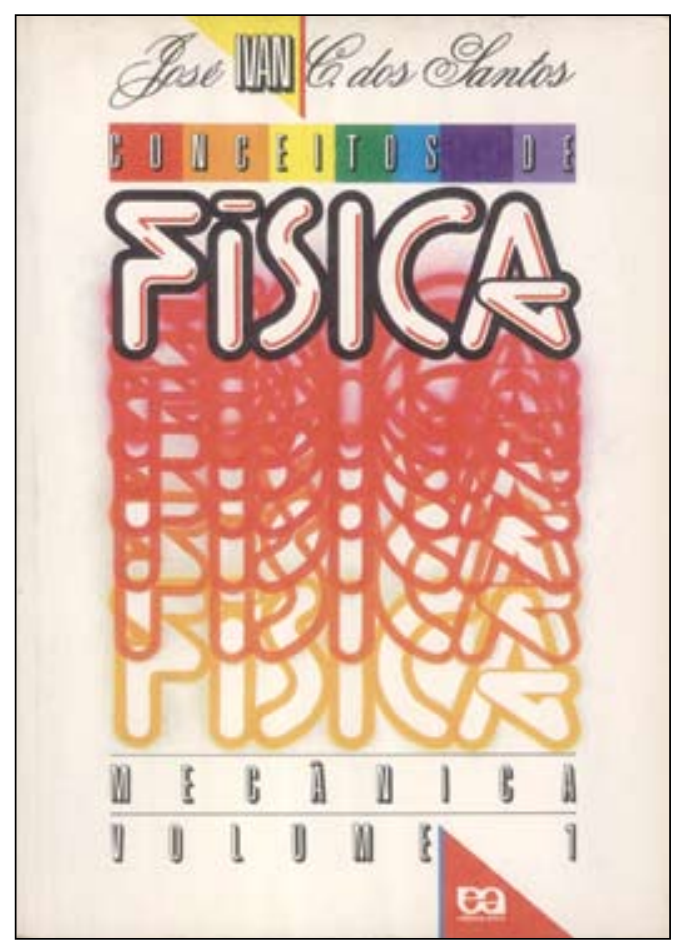

\section{Conceitos de Física - José Ivan dos Santos}

O que é texto, o que é imagem nessa capa? O que pode ser tirado ou modificado sem quebrar a coesão formal e nossa apreensão unitária e totalizadora e principalmente agradada esteticamente?

Lemos com clareza e facilidade cada informação textual, que aparece individualizada mas habilmente articulada com as demais, de maneira que é difícil dizer o que é mais importante, se o nome do autor, que aparece no topo, ou a primeira

Conceitos de Física. José Ivan C. dos Santos. 1994. Design Ary Normanha e Paulo César Pereira. $(24,0 \times 17,0 \mathrm{~cm}$; plastificada). Editor João Guizzo/Ronaldo Duarte Rocha. parte do título, logo abaixo. É certo que a palavra Física, parte do nome destacada para evidenciar a disciplina, aparece realçada pela dimensão, contraste do tipo de letra e espessura do contorno e como parte superior de um grafismo central. E a informação de conteúdo e volume aparecem no pé do campo, como informação complementar inferior às demais mas com resguardo visual para cumprir sua função individualizadora. Mas o grande retângulo em pé contrastando com o campo branco da capa é apreendido como um todo, e é nele que se dá a organização visual que amarra as formas que o compõem e dirige nossa atenção diferenciada a elas.

Os dois triângulos, no topo e no pé, criam detalhes interessantes pela quebra da linearidade horizontal e das formas retangulares dos outros elementos e se relacionam pela situação de oposição, servindo para sustentar os destaques ao nome mais conhecido do autor e o logotipo da editora.

O caráter mais conceitual e generalizador - e, portanto menos particularizador e anedótico - que uma solução exclusivamente tipográfica pode propiciar para conteúdos abrangentes como o de uma ciência, pode também ser qualificado e enriquecido. É o que acontece com o recurso a duas referências "figurativas" oferecidas tanto pelo desenho do tipo e seu tratamento volumétrico aludindo aos letreiros de néon e eletricidade, como pelo tratamento cromático e o adensamento da superposição da palavra, aludindo a movimento, a mudança de estado e à óptica. 

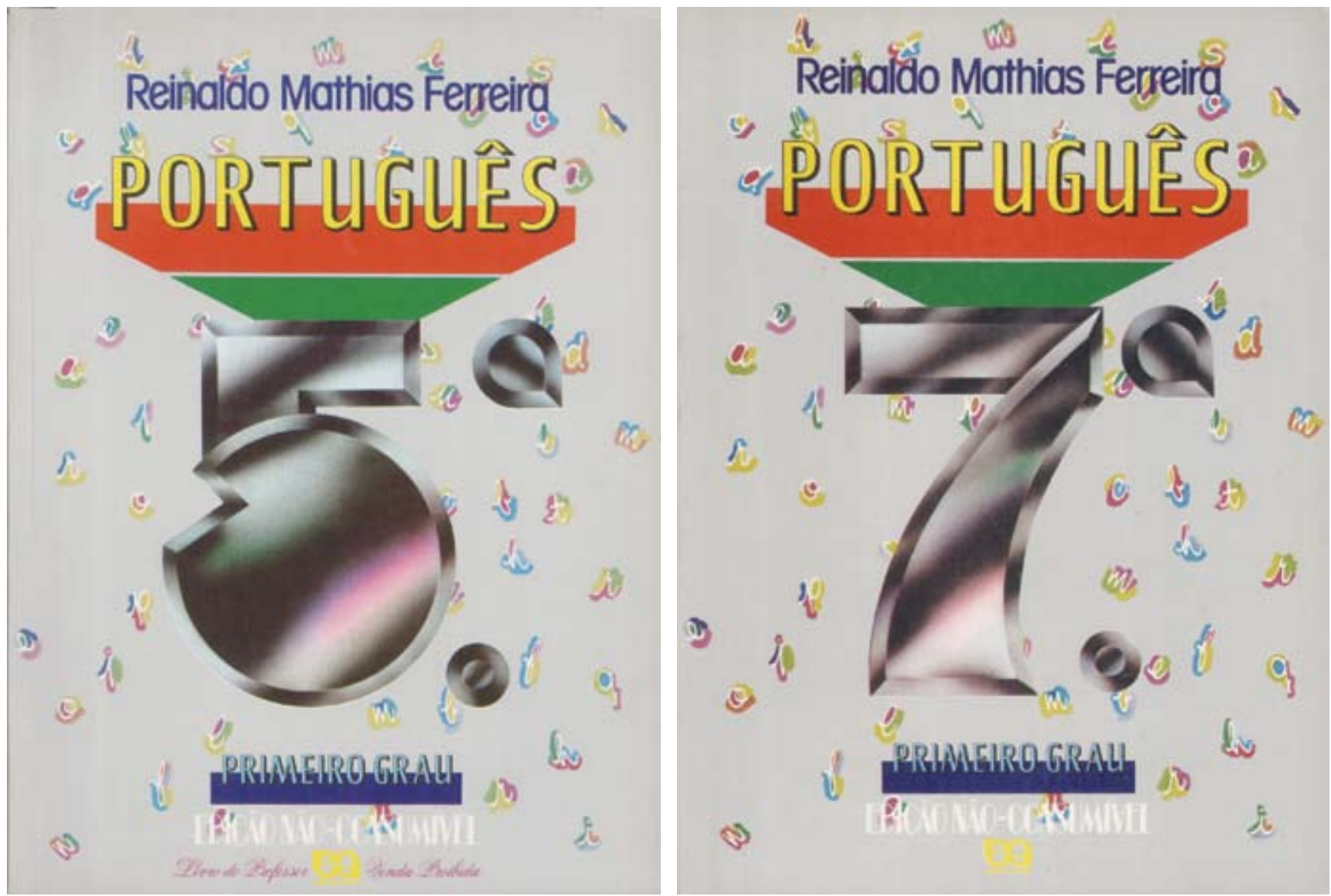

Português. Reinaldo Mathias Ferreira. 1986. Design Ary Normanha. $(27,5 \times 20,2$ $\mathrm{cm}$; plastificada). Editor Sandra Almeida.

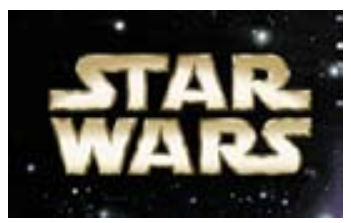

\section{Português - Reinaldo Mathias}

Nessas capas, a superfície de fundo já apresenta um estímulo para os sentidos pouco usual nos livros didáticos, com a impressão em tinta metálica prata, que comunica também o sentido de valorização do objeto, por associação tanto à prata como ao próprio aço, símbolo do moderno e do tecnológico. Uma textura gráfica com letras manuscritas bem informais e em arranjo livre e espontâneo, com colorido suave, quebra a frieza associada ao metal, dando uma vivacidade delicada ao fundo.

As informações de autoria, disciplina, série e grau aparecem num plano à frente, com a disciplina e a série destacadas mais à frente ainda e sustentadas e relacionadas pela forma triangular vermelha e verde, num conjunto organizado simetricamente por um eixo vertical. Este layout, que poderia ser tachado de rígido e formalista - abordagem pouco frequente nas capas da editora — dá uma certa solenidade ao conjunto, mas se justifica para sustentar o grande algarismo tratado como ilustração principal, que identifica cada volume.

Este algarismo é o elemento mais importante e tanto sua colocação central como sua construção geométrica com corte hightech preciso e efeitos de superfície realistas se referenciam a uma iconografia bastante popular no cinema e outras mídias, num flerte com o que era apreciado e valorizado pelo público. A textura mais desorganizada e orgânica do fundo ameniza a rigidez, reforça pelo contraste o aspecto hightech do algarismo e sua volumetria e confere espacialidade à capa. 


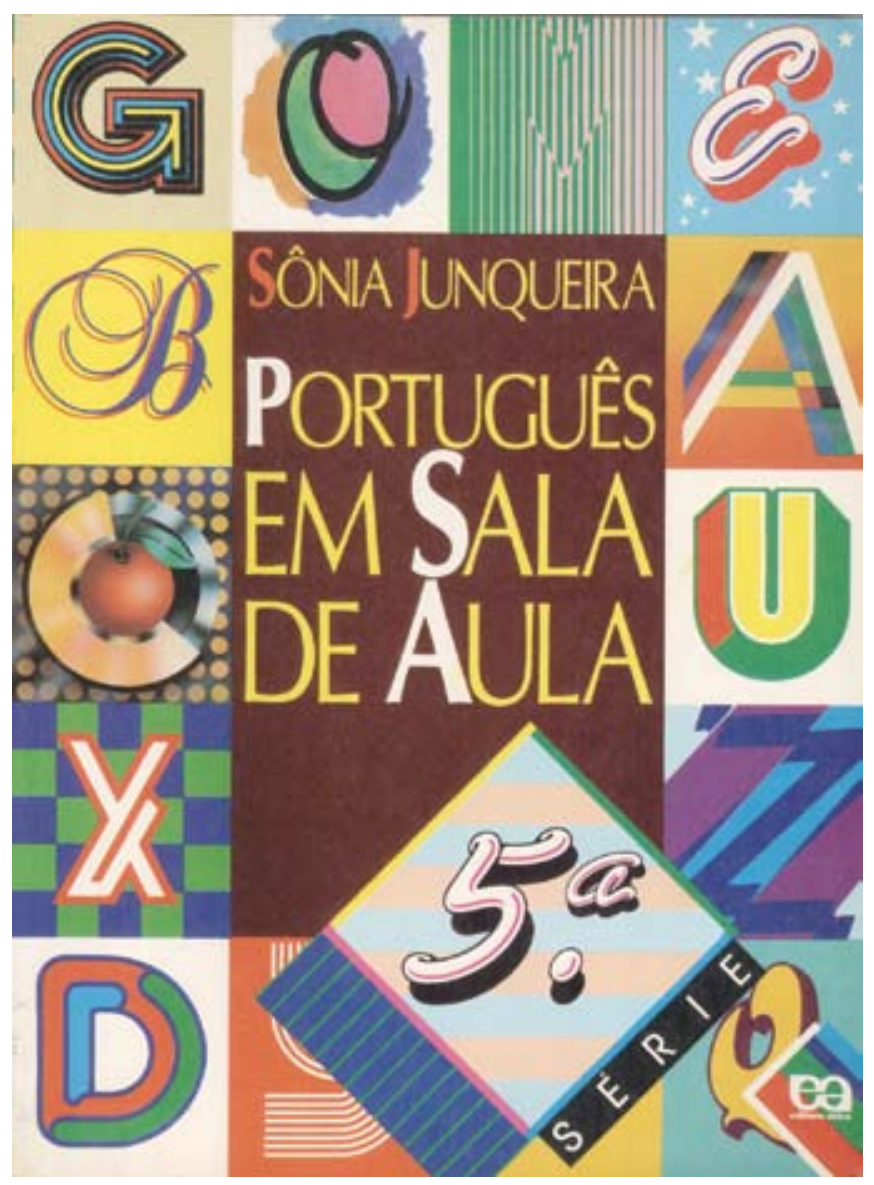

\section{Português em sala de aula - Sônia Junqueira}

Nesse caso, não se trata exatamente de uma capa tipográfica, pois, excetuando a composição central com as informações textuais, as letras aparecem assumidamente como ilustrações.

Ao mesmo tempo que se percebe uma modulação precisa, que estrutura ortogonalmente a capa e determina o lugar de cada imagem e das informações textuais, o resultado é de grande apelo e sensação de liberdade e riqueza. A modulação não impõe rigidez, mas, sim, permite a coesão para um conjunto formado por células preenchidas com liberdade e imaginação.

Na informação da série há uma quebra da ortogonalidade, e o contraste estabelecido reforça essa informação, propiciando, ao mesmo tempo, um enriquecimento maior ainda do conjunto.

Embora lembre as caixas com objetos e letras do Comunicação em Língua Portuguesa, aqui a solução é totalmente gráfica, e as letras são diretamente as formas, os objetos, mas sem construir nenhum sentido verbal.

Estas capas servem para provocar uma reflexão sobre onde reside a ideia central de uma mensagem visual, se num conceito ou conteúdo verbal traduzido para um equivalente visual, ou se numa ideia diretamente gráfica que já expressa conteúdos a partir de sua conformação. Na leitura dessa capa segundo uma semiótica que aborde o fenômeno visual a partir de parâmetros linguísticos, teríamos em primeiro lugar um plano de expressão em que signos linguísticos, as letras, apa-
Português em sala de aula. Sônia Junqueira. 1992. Design Ary Normanha. $(27,5 \times 20,2$ $\mathrm{cm}$; plastificada). Editor Sandra Almeida. 


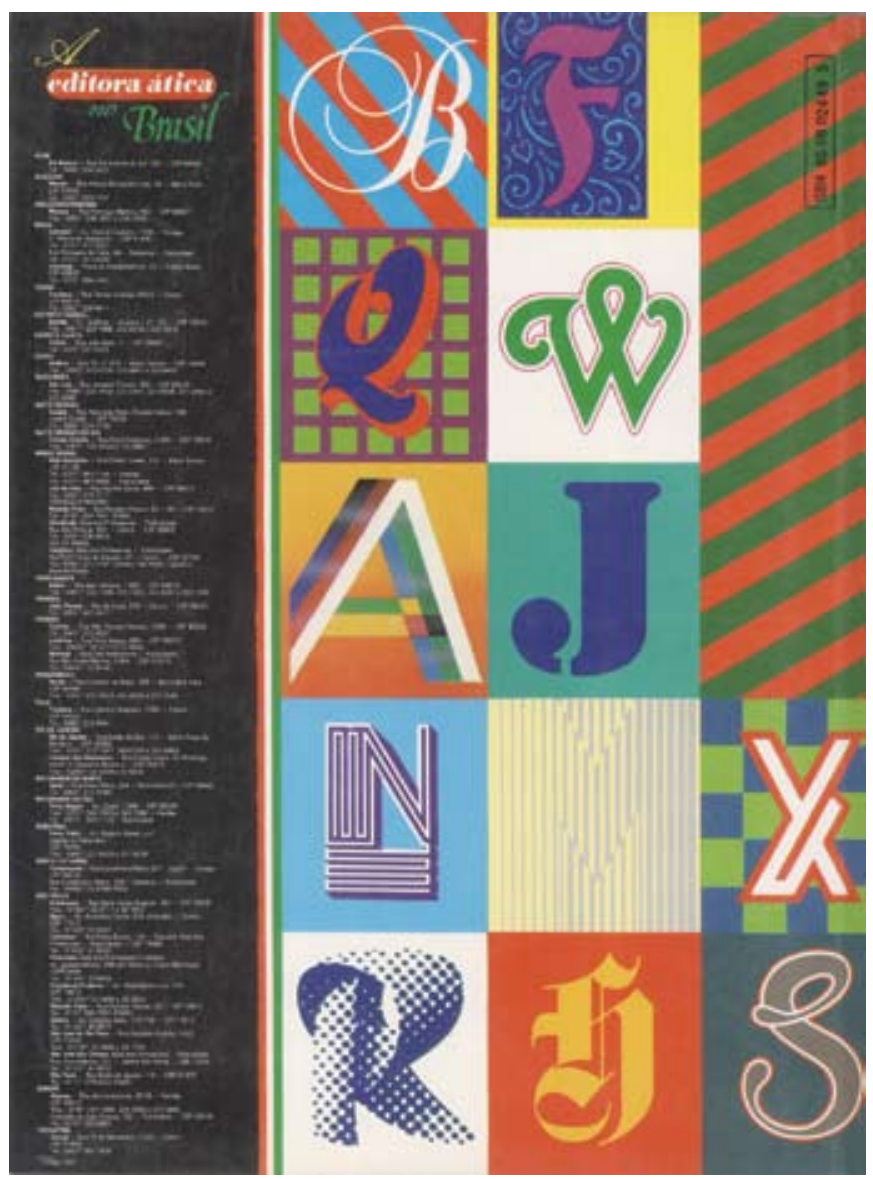

recem isolados dentro de uma estrutura modular e transformados em imagens, com cores, formas etc., e gravitam em torno de uma área central em que, aí sim, e em oposição formal a eles, as letras aparecem organizadas, sobre um fundo homogêneo, formando palavras e um título, um texto verbal. A essa oposição básica no plano da forma, do significante ou da expressão, corresponderia um significado também opositivo no plano do conteúdo. Talvez algo como: letras podem ser tomadas como formas que podem propiciar apelo aos sentidos e comunicar sensações mas, centralmente, como tarefa principal, mais importante, organizam textos que comunicam sentidos mais precisos que sensações, como, por exemplo, o título da obra que se lê.

Outras oposições ou contrastes formais podem ser encontrados e fazer a correspondência no plano do conteúdo, para ao final do processo se estabelecer com maior precisão o sentido exato da peça de design que é esta capa. No entanto, esse processo de leitura, que pode permitir perceber aspectos reais do objeto lido, corre também o risco de perder alguma coisa no caminho - que a comunicação do principal sentido já ocorreu, antes de qualquer raciocínio.

As letras com essa variedade de desenho já existiam como tipos disponíveis em fotocomposição e letras transferíveis e foram a matéria-prima para intervenções, colorizações, fundos, com vistas a resultados plásticos a partir de uma ideia linguisticamente muito simples e até pueril, o conhecimento de que qualquer público associa letras com a escrita e com a língua. Isso é muito pouco como conteúdo para gerar um design, sendo mais plausível supor que o universo de fontes visto cotidianamente nos catálogos de tipos tenha fornecido a inspiração diretamente visual e potencialmente mais promissora, visando em primeiro lugar ao interesse e à receptividade do público ao apelo estético-visual. O mais foi construir uma estrutura visual que organizasse as imagens e trabalhá-las com vistas ao prazer visual, à pregnância da forma e à comunicação, com o conhecimento e a experimentação desenvolvidos com os materiais e procedimentos da linguagem visual. Nao é possível falar em sentido com base em parâmetros de outra linguagem, desconsiderando a bela realização que é esse design, pois aqui o sentido transcende em muito a ideia de letra como célula da língua e se concretiza na forma, e não na ideia. 


\section{ESCLARECIMENTOS COMPLEMENTARES}

\section{1 alcance da renovação visual das capas da Ática}

Restringindo o campo de pesquisa ao das capas de livros didáticos é praticamente impossível encontrar exemplos anteriores de design com os quais as capas de Ary Normanha e Mário Cafiero tenham alguma afinidade, a não ser outras dos mesmos designers. Na verdade, é possível afirmar que a linguagem dessas capas constitui uma ruptura com o que era majoritariamente produzido no Brasil até então nesse segmento editorial. Dadas as características das editoras de didáticos e a história e aspectos do mercado já citados, este segmento editorial ficou bastante alheio e defasado em relação às linguagens e ao gosto do público que outras mídias já veiculavam. E as referências visuais a que essas capas remetem serão encontradas em outros segmentos da comunicação impressa no Brasil e inclusive no exterior.

Assim, é possível creditar a iniciativa da Ática com a renovação do design de capas à intenção da editora em afirmar uma imagem de modernidade e inovação aliada à confiança nos resultados comerciais decorrentes dessa postura. E o resultado deve ter sido altamente compensador, porque levou à consolidação de uma estrutura bastante complexa e cara, com autonomia e poder de decisão do profissional envolvido sobre os aspectos visuais, situação talvez inédita entre as editoras brasileiras. Há um reconhecimento explícito da importância não só da linguagem visual para a comunicação das intenções da obra junto ao público e para seu sucesso comercial, mas principalmente daquele que é o seu agente qualificado, o profissional do design gráfico, aparentemente contrariando a prática vigente na época.

Indício desse reconhecimento é o fato de que, uma vez estabelecida a autonomia de decisão, mesmo com o crescimento da editora e o sugimento de novas editorias, nunca o departamento de capas, mais tarde chamado de Projetos Especiais, precisou submeter as soluções desenvolvidas à aprovação dos editores de texto e mesmo do departamento comercial.

Segundo Normanha (2008), nunca se colocou em questão essa prerrogativa, obtida diretamente junto à direção da empresa, embora reconheça que nem sempre as soluções agradassem a todos, o que considera um fato normal, que não interferia na necessária autonomia de decisão de que dispunha. Para ele, quanto mais gente fosse ouvida, melhor poderia ser a resposta, mas esta era responsabilidade sua. Para esclarecer esta posição, faz um paralelo entre a atividade do editor jornalista que conheceu na sua experiência anterior e a do editor de texto atuante naquele momento nas editoras.

A função do editor jornalista — particularmente o de revistas — era bastante definida e estabelecida por uma prática já consagrada na capacidade de avaliar a integração de texto e imagem, em que cabia até o questionamento total da interpretação do ilustrador ou diagramador e a solicitação de um novo trabalho, mas nunca a determinação do que e de como tinha de ser feito, cabendo ao profissional da arte as decisões neste campo. 
Já a função de editoria numa editora de didáticos naqueles tempos não era muito bem estabelecida nesse aspecto, sendo assumida à medida do crescimento profissional, dentro da própria empresa, de pessoas em cujos critérios prevalecia a experiência das funções anteriores, ligadas essencialmente ao texto, e que geralmente não reconheciam a linguagem visual e a percepção da imagem como um processo diferenciado da leitura do texto e sua autonomia no processo de comunicação, não por incapacidade mas pelas condições concretas do exercício do próprio trabalho e do ineditismo da situação. No entender de Normanha, as piores soluções são as que tentam conciliar pedidos e interferências sobre um trabalho feito que acabam quebrando sua unidade e coerência formal; se o trabalho não atende as necessidades de comunicação, no seu entender deve ser descartado, e o problema reinterpretado, de modo a levar a uma nova solução sob responsabilidade exclusiva do artista gráfico.

É importante notar que as capas, fossem montagens tridimensionais, fossem as ilustradas — independentemente do traço do ilustrador — as fotográficas, ou ainda as exclusivamente tipográficas, todas formavam um conjunto em que se podia reconhecer não só a autoria de quem as concebeu, como a própria identidade da editora. Essa imagem era dada através de seu produto, o livro, e não de uma assinatura de marca nem tampouco de publicidade agregadas a ele. Este é um capital difícil de ser construído e é um resultado que não foi alcançado na época por nenhuma outra editora de livros escolares no país. Pode-se supor que a contratação de designers posteriormente por algumas outras editoras e a consequente elevação da qualidade de suas capas se deva em alguma medida ao impacto causado pelas capas da Ática, o que em última instância contribuiu para modernizar a linguagem do livro didático brasileiro a partir daqueles anos.

Sobre as características de linguagem dessas capas e do próprio trabalho de Ary Normanha, deve-se ressaltar que sua contribuição para a modernização do livro escolar não teve como paradigma a vertente modernista construtivista instaurada a partir do estabelecimento da arte concreta no Brasil e da instalação dos cursos inspirados nos exemplos e currículos da Bauhaus e de Ulm. Como tivemos oportunidade de ver, suas referências vieram mais das artes gráficas praticadas nos jornais e revistas, sem dúvida também influenciadas pelas correntes modernistas, mas também pela arte comercial e publicitária, pela forte presença da fotografia e da ilustração como elementos gráficos de comunicação de massas. No caso de Ary Normanha, a própria condição de autodidata lhe deu muita liberdade no uso dos grids e chassis, de forma que é constante a flexibilização e mesmo o abandono de esquemas gráficos estabelecidos a priori, em nome de uma fantasia e comunicação mais adequada, numa direção diversa da dos designers de formação acadêmica atuantes naqueles anos. 


\subsection{O design do miolo}

Ao contrário de outras editoras exclusivas de didáticos, a Ática teve muito cedo a oportunidade de ver a superioridade da abordagem de projeto unitário do livro exatamente pela experiência com as obras não-didáticas. Desde o início estas tiveram um tratamento de objeto único, não fragmentado em capa e miolo. Ary Normanha e Mário Cafiero fizeram projetos de coleções e de livros com essa abordagem, que corresponde à noção de design em seu sentido completo: projeto de produto considerando as necessidades de produção e de consumo, incluindo a ergonomia e a articulação formal derivada de um princípio compositivo básico.

No entanto essa visão não prevaleceu e talvez nem tenha se colocado em relação ao miolo dos livros didáticos. Segundo depoimento de Irami Silva, que entrou na empresa em 1967 e ocupou a chefia de um dos vários departamentos de arte encarregados do projeto e diagramação de miolos dos livros, desde muito cedo a editora estruturou a produção dos miolos deixando a capa como um item a ser resolvido à parte, como uma necessidade para dar conta da complexidade e quantidade de tarefas envolvidas na finalização de inúmeras obras em prazos sempre apertados que caracterizam a produção de didáticos (SILVA, 2009).

Para Ary Normanha, a direção da empresa atribuiu exclusivamente à capa a função de atrair o interesse do público comprador e não ao projeto gráfico do livro como um todo. Assim, organizou a linha de produção desvinculando totalmente os setores de criação das capas do desenho e diagramação do miolo. Aqui parece haver uma conveniência de ordem operativa que se estabeleceu acima de todos, aparentemente para se obter o rendimento e a fluidez do trabalho exigidos.

Embora houvesse atenção ao miolo - e, com o tempo, alguns receberam mesmo um cuidado de projeto gráfico mais elaborado e diferenciado - a Editora tem poucos exemplos de projetos completos de capa e miolo até o final da década de 1980. Quando isso acontece, é tão evidente a superioridade formal do livro resultante, que só necessidades operativas e o temor de alteração de uma estrutura já implantada explicariam a permanência da separação completa de desenho das duas partes constitutivas do livro como uma regra para a maioria das obras.

A experiência de estudantes e professores era de forma geral com o livro fragmentado, em que já a página de rosto vai em direção formal diversa da que foi vista na capa. Isso acaba parecendo até mais acentuado nas obras da Ática, em que as capas ofereciam soluções mais inusitadas e instigadoras, com formas muito características e marcantes, mas que não encontravam eco nem mesmo nas páginas pré-textuais do miolo. Em alguns casos, vê-se o logotipo criado para a coleção, com um desenho bastante marcante e expressivo, como uma marca de identidade entre os volumes da coleção, seguido de um outro logotipo completamente diferente do encontrado na capa. Essa ausência do sentido de unidade em um objeto que é único deixa de oferecer a oportunidade de aprofundar a experiência obtida com a capa, de perceber que a forma carrega um sentido não arbitrário e de entender a linguagem visual como um instrumento poderoso para comunicar intenções e ideias. 

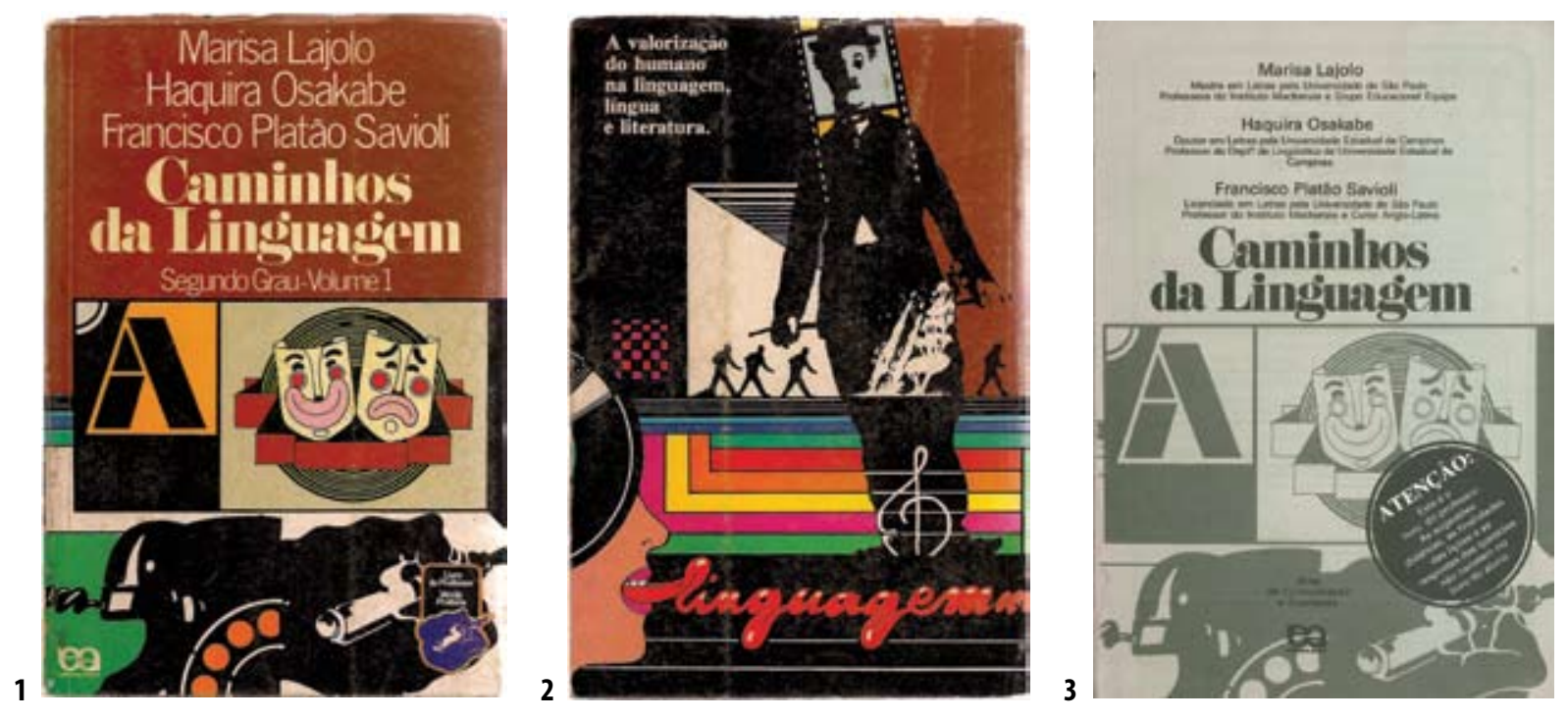

\begin{abstract}
1/2/3/4 Caminhos da linguagem. $2 .^{\circ}$ grau. Marisa Lajolo, Haquira Osakabe e Platão Savioli. 1977. Capas, quarta capa, rosto e dupla do miolo.
\end{abstract}

Projeto gráfico Ary Normanha; capa Mário Cafiero; edição de arte Ary Normanha, René Ardanuy e Antonio Amaral Rocha. $(21,5 \times 14,5 \mathrm{~cm})$

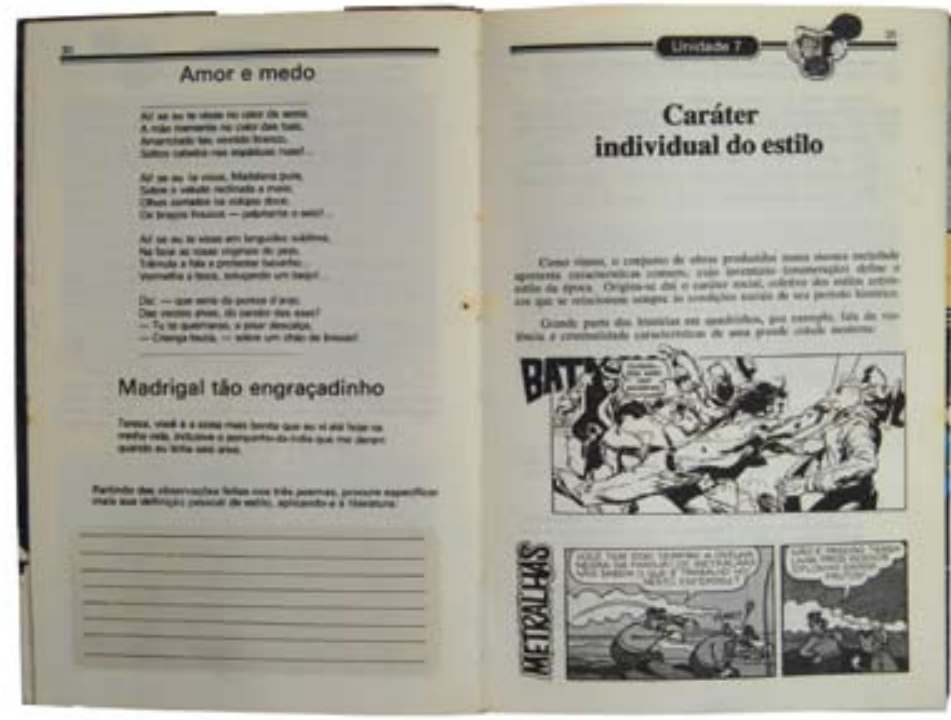

5/6 Coleção Aquarela, Língua Portuguesa. 1. grau. D'Olim Marote. 1990. Capa e rosto.

Capa Ary Normanha, ilustração Marcus de Sant'Anna. Edição de arte de miolo Irami $B$. Silva. $(27,4 \times 20,2 \mathrm{~cm})$
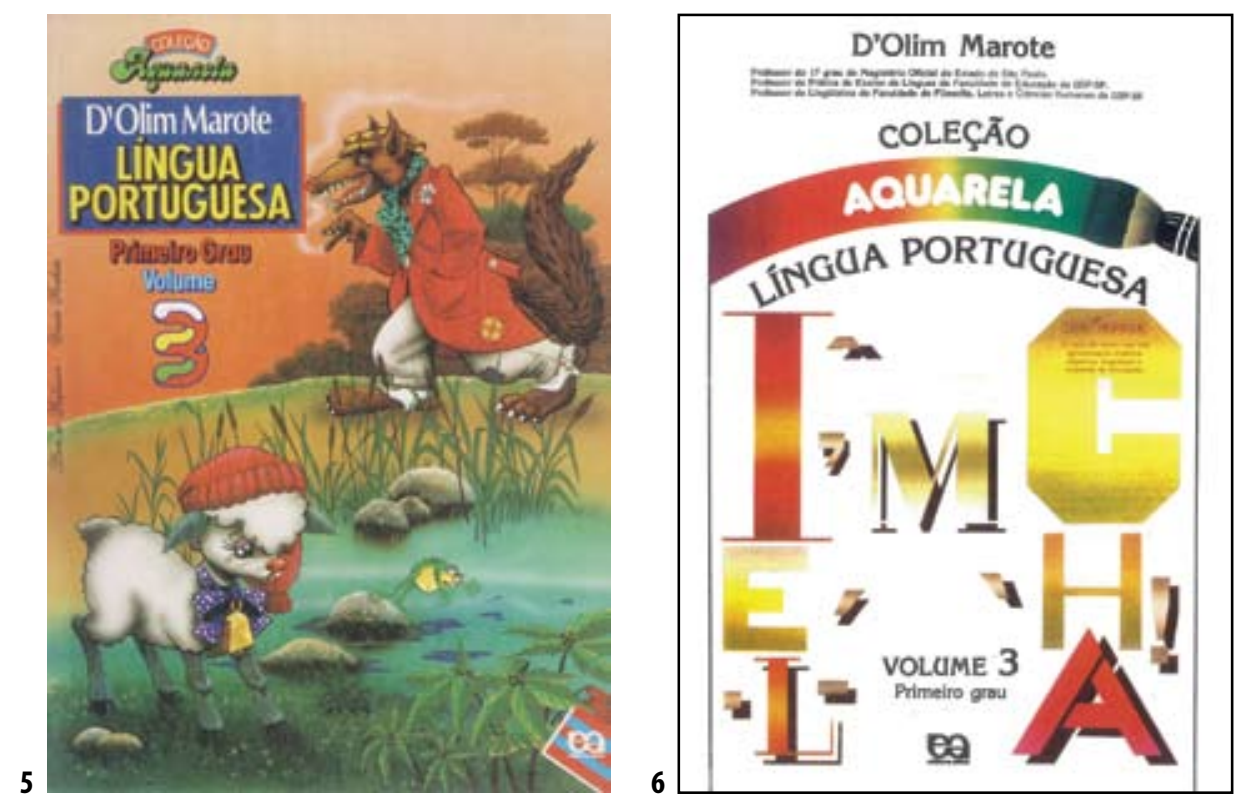


\subsection{Sobre a leitura das capas}

As capas selecionadas para serem aqui apresentadas correspondem a títulos de grande desempenho comercial e/ou significação em termos de solução de design. Como a produção da editora foi muito extensa, não se pretendeu abranger todas as disciplinas. Além disso, um acidente nas instalações da biblioteca obrigou a editora ao fechamento do acervo, impedindo uma possível ampliação da pesquisa. De qualquer maneira, o panorama aqui oferecido é significativo da qualidade da produção e do seu impacto e importância no espectro do livro didático no Brasil no período analisado.

Evidentemente, o público a que se destina uma obra como as analisadas não procede a uma leitura como a que fizemos para apreciar ou rejeitar uma capa. $O$ design da capa visa atingi-lo de maneira direta, agradá-lo, convidá-lo a conhecer o livro e se envolver com ele, e o faz por apelos bem menos racionais, dirigindo-se em primeiro lugar aos seus sentidos - pelo domínio das relações sintáticas do material pictorial por parte do designer — mas também ao seu intelecto — a partir do reconhecimento do seu repertório - na busca de efeitos de sentido.

A análise feita teve o sentido unicamente de refazer o percurso de construção do objeto gráfico e identificar seus elementos constitutivos, o modo como são usados e os efeitos que se consegue com eles, para compreender o que esse objeto propõe como significado e a eficácia (ou ausência dela) na comunicação pretendida. Assim, considerou-se convenientes a síntese e a economia na identificação de um significado principal contido em um design em respeito à essencialidade e importância desse significado e ao modo eficaz e direto com que atinge seu público, evitando também repetições e redundância.

Por isso, apenas uma minoria de capas recebeu uma análise mais detida, em que se procurou-se explorar mais as possibilidades de significados propostos. Estes foram referência para uma leitura mais direta da maioria das capas, de que se procurou identificar apenas os significados principais, relacionando-os aos materiais e às estratégias visuais utilizados para sua construção.

No caso das análises mais extensas, trata-se de desvendar de forma mais pausada e investigativa como uma obra visual ou gráfica é construída de modo que, além de comunicar esses significados mais essenciais, apresenta outros significados menos óbvios, sejam aqueles dirigidos a parcelas menores do público sejam aqueles não necessariamente conscientes no que se refere a seu autor. Aqui podem entrar marcos de percepção e significação construídos histórica e socialmente, em que designers, artistas e público simplesmente se situam nos trabalhos de emissão e decodificação de mensagens, mas que a leitura treinada e especializada da obra ou mensagem pode revelar. Esse trabalho pressupõe nunca abandonar a observação do objeto em questão, sua materialidade e realidade fenomenológica próprias, e o uso de instrumental teórico adequado, sob o risco de construção de discursos genéricos e descontextualizados. Assim, não há como fugir do conhecimento específico dos meios e recursos do modo de expressão visual, que artistas e designers usam para construir suas obras, como instrumental teórico principal. ${ }^{16}$ 16 Sandra Ramalho e Oliveira pro-
cede a leituras de objetos gráficos,
obras de arte, artesanato, moda e
design, e esboça alguns parâmetros
e metodologias para essa leitura em
seu livro Imagem também se lê (OLI-
VEIRA, 2006). 
Uma questão que surge da busca de ideias e significados numa configuração visual: poderiam eles ser igualmente expressos por um texto escrito? Ou, perguntando de outra forma: essa configuração visual é apenas uma tradução para o modo visual de conteúdos elaborados no modo do pensamento verbal? Essa questão é crucial, dados o poder creditado em nossa sociedade à linguagem verbal e a tentativa de compreender todas as formas de expressão através do modelo linguístico, como mencionamos na Parte I.

Pode-se tentar, mas o que parece mais plausível é que essa própria ideia já é gerada dentro de um outro campo mental, que trabalha com outro tipo de "raciocínio" e processos. Ou seja, há uma impossibilidade de se obter uma tradução plena, a não ser que se considere que uma longa descrição verbal do que está sendo visto comunique o mesmo conteúdo que a visualização pura, simples e direta. Essa intradutibilidade se deve ao fato de que cada modo semiótico tem o seu potencial de criar e comunicar significados e que há significados que são próprios de cada um, ou, pelo menos, melhor produzidos por um do que por outro. Na origem de tudo estariam as características básicas dos processos perceptivos e cognitivos envolvidos em cada modo de recepção e construção de sentido.

Assim, na construção de um enunciado gráfico, textos devem ser vistos como elementos visuais, com formas, cores, pesos, tanto quanto figuras ou outros elementos, e sua articulação ou participação na composição geral não segue as regras da articulação escrita, a sequência linear ou sintática da frase, mas as da composição e comunicação visuais. O design gráfico não seria, portanto, um modo híbrido, que reúne materiais de dois modos diferentes, cada um conservando as suas características e modos de decodificação, independentes um do outro, de significados autônomos, mas um modo globalizante, comandado pelos processos de percepção e cognição mais velozes e holísticos. O momento da leitura verbal dos textos, agora, sim, seguindo o processo linear e sequencial do modo linguístico, capaz de veicular conteúdos narrativos e causais que o modo visual não consegue tão eficazmente, é posterior ao envio de mensagens não verbais as quais podem potencializar esses novos conteúdos ou entrar em contradição com eles, gerando inconsistência e desacreditando-os, num paralelo com o conhecido processo da voz desmentindo as palavras.

Esse é um modo de conhecimento que um design, e o dessas capas em particular, é capaz de evidenciar e apresentar para a reflexão. Toda uma cultura imagética foi construída com base nos procedimentos da linguagem visual e um enunciado gráfico - produto de um raciocínio, de uma atividade profissional específica, que envolve conhecimentos e técnicas, tradições e estilos de linguagem — pode estabelecer relações com ela. Nao apenas através das próprias imagens que esse design veicula, mas principalmente com o diálogo com outros enunciados de design produzidos anteriormente com os quais se relaciona. 
CONCLUSÕES 


\section{DESIGN DE CAPAS NOS ANOS 1970 E 1980: UMA SÍNTESE}

Refletindo a expansão do ensino público e privado iniciada em décadas anteriores e que prosseguia com grande força, a década de 1970 apresentou um crescimento ímpar da produção de obras didáticas, feitas por novas editoras e pelas antigas, que ampliaram sua capacidade com vistas a atender esse mercado.

A expansão do ensino se deu num contexto de crescimento da produção de bens culturais veiculados por antigas e por novas mídias, que trazem novas estéticas e se dirigem a novos e mais vastos públicos. A expansão da televisão e da imprensa, comandada por grandes grupos empresariais, se dá com base em grande profissionalização de seus quadros, tanto em gestão e comercialização como na produção de linguagens.

As linguagens da comunicação de massa se apoiam principalmente no desenvolvimento das tecnologias de obtenção e reprodução da imagem fotográfica e cinematográfica, criando novos parâmetros de realismo que vão ser empregados principalmente na publicidade e na televisão. O uso da cor se aperfeiçoa na mídia impressa e vai aparecer na televisão.

Setores mais vastos do público são atingidos pela indústria cultural e seus veículos. Criam-se produtos culturais, acompanhados de produtos materiais, dirigidos especialmente para a infância e a juventude. Há uma cultura jovem, incluindo aspectos contestatórios, que serão mais ou menos absorvidos e reproduzidos pela indústria cultural.

Os veículos de comunicação de massa, particularmente a televisão, e a Rede Globo em particular, vão atingir cantos do país antes isolados, dentro de uma política de "integração nacional" com vistas a criar um grande mercado para a publicidade mas também para a divulgação e o controle político e ideológico por parte do regime militar instaurado em 1964.

A imprensa, particularmente a de revistas dirigidas a públicos mais amplos ou segmentados, incluindo-se aí os fascículos colecionáveis, vai ter grande desenvolvimento e atingir todas as regiões do país. Do lado da produção, vai absorver toda a mão de obra qualificada existente e vai investir no seu desenvolvimento. Do lado do consumo, vai levar essa nova visualidade impressa para grandes setores da população, em todas as regiões do país.

A indústria do livro escolar, como parcela da indústria cultural, vai apresentar um comportamento particular. As editoras mais antigas são tradicionalmente vinculadas a uma cultura escolar caracterizada por um certo isolamento e impermeabilidade à influência de outros meios. Ao mesmo tempo têm quadros profissionais formados nas linguagens e na tecnologia gráfica da produção tradicional do livro.

As novas editoras são dirigidas por egressos de outro meio, jovens professores de cursos preparatórios que se tornam autores de seu material didático e encontram a oportunidade de ser seus próprios editores, e, em seguida, editores de outros autores. Embora talvez mais em contato e sensíveis à informação da cultura de massa, não têm experiência editorial e não contam com mão de obra formada para profissionalizar todos os aspectos de seu negócio. Vão buscar profissionais nas 
empresas tradicionais mas também investir em quadros sem formação específica mas em que identificam algum potencial.

O que é comum à maioria das novas editoras é o pequeno grau de profissionalização de sua gestão e a falta de uma fonte formadora de mão de obra qualificada, tanto para as atividades relacionadas à edição de texto, como para a produção visual e também para a gráfica. As primeiras e as últimas são mais fáceis de suprir, com a formação inicial propiciada pelas escolas de letras ou jornalismo e pelas de artes gráficas, que podia ser complementada pela experiência no próprio trabalho. Já a formação em design para a produção de projetos gráficos de capa e miolo em linguagens atualizadas é insuficiente para todo o mercado da indústria cultural. Mas, antes disso, sua necessidade não é plenamente identificada pelos novos editores, que reproduzem o não reconhecimento do modo visual e de sua importância para a construção de comunicação eficiente, o que era regra tanto no meio editorial didático em particular, como na sociedade como um todo.

Um aspecto dessa desvalorização é a aposta exclusiva no conteúdo textual e na autoridade dos autores como elementos suficientes para motivar o interesse de professores pelos livros. Mesmo que essas razões pudessem prevalecer, elas não precisariam excluir a necessidade de boa apresentação visual, principalmente como fator de motivação para seu usuário final.

O resultado é que as capas examinadas na pesquisa apresentarão as seguintes características:

- grande número delas trará a visualidade antiga, anterior à iconologia dos novos meios e desenhada conforme as técnicas e os meios anteriores a essa novidade; - grande número de capas também procurando incorporar a nova iconologia, usará os novos recursos mas sem dominá-los;

- um número menor de capas será produzido dentro ainda da lógica da produção de didáticos, porém mais bem realizada.

- um novo grupo de capas, pequeno, vai refletir a presença no segmento dos livros escolares do design modernista, ensinado nas poucas escolas da época, bem como as características inovadoras do design editorial das revistas.

O cômputo geral é que o livro didático, lançado num período em que os aspectos materiais e visuais se impõem como novos valores da comunicação de massa, é visualmente atrasado em relação aos outros setores da indústria cultural e seus produtos. O público de todas essas mídias e linguagens, no entanto, é o mesmo, o que contribuiria para reforçar o isolamento da atividade didática e da escola nesse mundo em rápida transformação.

A editora Ática — devido a particularidades de seu projeto editorial e de sua inserção cultural, ligadas às características de sua direção e equipe editorial — produzirá a resposta mais articulada ao problema, com a contratação de profissionais qualificados oriundos do design editorial praticado nas revistas de grande tiragem, que trouxeram soluções de impacto e bem realizadas. O investimento se completa com as condições propiciadas para a realização dos projetos complexos e caros, que resultam em capas que cumprem plenamente sua função comunicativa e publicitária, com sua visualidade se apoiando não no repertório de uma cultura 
escolar estreita, mas numa cultura visual mais ampla e atualizada e nas técnicas da linguagem visual aplicadas à comunicação de massa.

As consequências mais imediatas, que teriam contribuído com o sucesso comercial da empresa, seriam:

- a aproximação com o público, principalmente de professores, que decidiam pela compra, mas também de alunos, seus usuários finais;

- a construção da identidade da editora, a que se associava a imagem de modernidade e qualidade.

Mas outros aspectos podem ser deduzidos. Ao fazer seus livros portadores da visualidade mais bem realizada do período, a Ática permite o convívio com objetos gráficos de qualidade e amplia as referências, a cultura visual e o gosto de seu público. Insere o livro didático na produção maior da cultura e torna-o interessante e participante da visualidade de seu tempo, distinguindo-o da produção massiva e desqualificada que também ocorria em outros meios. O sucesso comercial também tem influência sobre as editoras concorrentes, levando-as a investir em design, contribuindo, assim, para a modernização do livro didático brasileiro.

As leituras das capas de Ary Normanha e Mário Cafiero vão mostrar soluções feitas para atrair os dois públicos, considerando-os não opostos, mas unificados como participantes do mundo da comunicação de massa. As possíveis diferenças, decorrentes de faixa etária, experiência de vida, interesses e repertório são superadas pelas características do design realizado.

Esse é o modo, aliás, como se dá o processo de comunicação na sociedade de massas. Evidentemente há uma grande diferença entre setores do público e entre indivíduos, que escapa ao domínio do designer, daí ele trabalhar com o conceito de um receptor médio ou ideal. Por sua vez, as soluções de design também não chegam da mesma forma para todos. Mas existe uma base mínima e comum de repertório e cultura que permite que a informação qualificada consiga falar a públicos heterogêneos. Para o que é conhecido de um público, garante-se a comunicação básica. Para a parte do público a que tal solução apresenta algum grau de novidade, este pode ser um fator primordial de interesse para a própria informação.

Existe uma dialética entre informação, significação e comunicação. Ocorre informação quando alguma coisa se destaca na paisagem. Ou seja, a base da informação é a diferença, não a semelhança. Por outro lado, só a informação, o novo, não resulta em comunicação, pois ainda é preciso que significados sejam construídos. Para isto ocorrer é necessário que se apoiem numa base conhecida, num repertório comum e, ao mesmo tempo, vão além dele. Assim, a comunicação efetiva se apoia no equilíbrio entre o novo e o conhecido. Quando alguma expectativa é quebrada, quando algum grau de violação do repertório conhecido ocorre, a informação é muito grande e a possibilidade de comunicação, ao invés de ser reduzida, é ampliada. Com relação ao olhar, é muito grande sua capacidade de adaptação, isto é, de absorver e incorporar o novo ao repertório conhecido, ampliando a experiência sensorial e cultural e preparando-o para novas assimilações e adaptações, num processo constante que caracteriza a própria cultura. O paralelo com o processo de ensino/aprendizagem é inevitável, se é que não é um de seus mecanismos. 
Nesse sentido, embora Normanha e Cafiero não se colocassem como pedagogos, nem sua atuação se desse dentro de um projeto pedagógico definido pela editora, sua produção trouxe uma contribuição que tenderia a ampliar as motivações puramente comerciais envolvidas na produção de capas:

- um estudante não se envergonhar do livro que é obrigado a carregar já seria um resultado considerado de grande valia; se ele puder se identificar com sua linguagem, reconhecer seus valores e gostos nele, o efeito motivador para a apropriação e uso do livro é maior ainda.

- uma boa realização de design, em que se perceba que alguma riqueza de sentido surge do diálogo entre palavra e imagem, ou da própria potência da imagem, é um estímulo a reconhecer a capacidade da linguagem visual como produtora de conhecimento.

Aqui, além dos objetivos mais pragmáticos do design, está aberta a possibilidade de ele cumprir também um papel pedagógico. 


\section{ALGUMAS REFLEXÕeS POSSÍVEIS}

O design do livro didático diz respeito à comunicação ou à Educação? Essa questão parte de uma premissa que opõe cultura escolar e sociedade de massas/indústria cultural, com cada uma portando valores próprios não miscíveis entre si. De fato, há interesses e valores diferentes e até em oposição, e não há como negar a necessidade de a escola ser um espaço para a transmissão de conhecimentos e para o desenvolvimento de práticas diferenciadas e distanciadas do que a maior parte da indústria cultural tem a oferecer nas condições atuais do país.

O design é também frequentemente acusado de em grande parte servir apenas ao comércio por estetizar superficialmente os produtos, atuando como uma ferramenta de marketing sem maiores compromissos com outros valores e necessidades, o que também não pode ser negado.

Essas constatações colocam questões de difícil resposta, que certamente não passam pela rejeição à indústria cultural e ao design, mas que não vão ser tratadas aqui. Apenas parace que este trabalho teve como um de seus resultados algumas possibilidades de reflexão sobre elas, que são apresentadas a seguir.

\subsection{Livro didático, produto da indústria cultural portador de conteúdos: tem de comunicar}

O livro didático é uma categoria ou gênero de livro, com especificidades relevantes e determinantes - basicamente resumidas em seu caráter de uso voltado para o ensino/aprendizagem no espaço e no período da vida escolar - que não alteram a necessidade de seu design se submeter às exigências de comunicação de conteúdos presentes em qualquer outro produto de comunicação e à metodologia própria do design do livro em geral.

Esse design tem que ter as mesmas características "sincréticas" do design gráfico em geral, ou seja, reunir linguagem verbal e visual num mesmo fenômeno unitário de percepção e criação de sentido, com as mesmas questões de repertório e "leis" das teorias da informação e da comunicação válidas para qualquer fenômeno comunicativo. O conteúdo curricular específico e a função educativa não alteram essa realidade. Pelo contrário, o conteúdo precisa ser transmitido, a função didática precisa se cumprir. Os materiais e a organização próprios da linguagem visual são o meio para a construção desse design e a formação profissional específica do designer, com todo o corpus de conhecimento dessa atividade, é a condição para a configuração competente do livro escolar. Nesse aspecto, educação e comunicação caminham juntas.

O trabalho mostrou que soluções de capas que se ocupavam unicamente com a exposição do conteúdo no sentido mais estreito possível, sem domínio dos meios da linguagem visual para a construção de formas pregnantes e que ignoravam o regime visual dos meios de comunicação de massa, colocavam-se, na verdade, fora do universo imagético e da experiência visual de seu público e provavelmente não atingiam a comunicação desejada. 
Já a produção bem-sucedida do ponto de vista da construção formal, do reconhecimento do universo imagético e dos interesses do público, referenciada na cultura visual sem limites artificiais - brasileira e mundial, popular e erudita buscando propiciar a emoção estética, não só será mais eficaz quanto à comunicação imediata dos sentidos da obra, como sustentará uma identificação mais duradoura pela ressonância conseguida com o seu público.

\subsection{Papel pedagógico do design: ensino de uma linguagem e transmissão da cultura visual}

Além do aspecto pragmático da comunicação obtida, realizações de design bem-estruturadas e surpreendentes chamam a atenção para si como expressão de um modo de comunicação diferente do verbal mas que também cria sentidos e provoca emoção. Soluções de design bem construídas permitem experienciá-lo como linguagem estruturada, que articula formas não arbitrariamente, mas segundo princípios que podem ser mais ou menos percebidos. Como a poesia é capaz de quebrar o automatismo do uso da língua chamando a atenção para a materialidade das palavras como significantes, as soluções visuais inesperadas e incomuns podem chamar a atenção para essa forma de linguagem relegada a segundo plano pelo predomínio do lógico-verbal na formação corrente na escola.

Não que um bom design de livros vá substituir e dar conta sozinho do que seria tarefa da escola e toda uma vivência que também e principalmente deveria ocorrer nela. Mas pelo menos ele não pode ir numa direção oposta às necessidades que uma educação completa hoje deveria propiciar.

Gillian Rose, utilizando o termo criado por Martin Jay, afirma que vivemos num regime visual que pode ser chamado de ocularcentrismo, devido à centralidade do visual na experiência da vida contemporânea nas sociedades ocidentais. A importância do visual foi crescendo da pré-modernidade para a modernidade, e desta para a pós-modernidade:

Sugere-se frequentemente - e se assume - que em sociedades pré-modernas imagens visuais não eram especialmente importantes, em parte porque havia poucas em circulação, e isso começa a mudar com o início da modernidade. Em particular, sugere-se que formas modernas de compreensão do mundo dependem de um regime escópico que equipara visão e conhecimento. [...]

Barbara Maria Stafford (1991), historiadora de imagens usadas nas ciências, argumenta que, em um processo iniciado no século XVIII, a construção dos conhecimentos científicos sobre o mundo tem crescentemente se baseado mais em imagens do que em textos escritos; Jenks (1995) sugere que é a valorização da ciência nas sociedades ocidentais que permite à compreensão cotidiana fazer a mesma conexão entre ver e conhecer. [...]

Conclui-se, assim, que a modernidade é ocularcêntrica. E se tem verificado que o visual é igualmente central na pós-modernidade; Nicholas Mirzoeff (1998, p. 4), por exemplo, proclamou que'o pós-moderno é uma cultura visual'. No entanto, na pós-modernidade, sugere-se, a relação entre ver e conhecimento verdadeiro, própria da modernidade, foi quebrada. Daí, Mirzoeff (1998) dizer que a pós-modernidade é ocularcêntrica não simplesmente porque imagens visuais são cada vez mais comuns, nem porque conhecimentos sobre o mundo são cada vez mais articulados visualmente, mas porque nós interagimos cada vez mais com experiências visuais totalmente construídas. (ROSE, 2007, p. 3-4. Trad. minha) 
Justamente nesse mundo - em que o período das capas analisado constituiu um momento de avanço da importância das imagens na vida e na cultura, e que chegou a um momento de forte presença de imagens da realidade virtual, a que se refere a última passagem da citação - está inserida uma escola que aparentemente não resolveu a compreensão e o ensino do fenômeno visual para o conjunto de seus frequentadores nem sabe como prepará-los para compreender o processo de construção dessas imagens, que na maior parte do tempo servem não para mostrar o mundo mas para ocultá-lo.

Se cabe à escola ser capaz de ensinar a ver tanto quanto ensinar a ler, o livro didático deveria também expressar objetivos pedagógicos mais ambiciosos em sua visualidade. O design do livro didático, mesmo partindo de seu caráter de uso específico, que o distingue de outros, pode se inserir e ter a mesma qualidade da produção de design presente em toda uma produção livreira que informa e sensibiliza para os valores visuais, propiciando uma experiência insubstituível e enriquecedora para estudantes e docentes. Sua contribuição para a educação pode ir além da indispensável veiculação competente de conteúdos disciplinares e se estender para outros aspectos da formação cultural mais ampla dos indivíduos. 


\section{BIBLIOGRAFIA*}

* De acordo com: Associação Brasileira de Normas Técnicas. NBR 6023: informação e documentação: referências: elaboração. Rio de Janeiro, 2002. 
ABRAMOWSKI, Ana. El lengaje de las imágenes y la escuela: ¿es posible enseãr y aprender a mirar?. In: Tramas - Educación, imágenes y ciudadanía. Disponível em: <http://www.tramas.flacso.org.ar/print/43>. Acesso em: 5 jan. 2009.

ARAÚJO, Emanuel. A construção do livro. 4 impr. Rio de Janeiro: Nova Fronteira; Instituto Nacional do Livro, 2006.

BAHIANA, Ana Maria. Almanaque anos 70. Rio de Janeiro: Ediouro, 2006.

BITTENCOURT, Circe Maria Fernandes. Livro didático e conhecimento histórico: uma história do saber escolar. Tese de doutorado, Faculdade de Filosofia, Letras e Ciências Humanas, Universidade de São Paulo, São Paulo, 1993.

O que é livro didático. In: Leitura e literatura para a infância e a juventude. Anais do 2. Seminário Nacional sobre Literatura Infanto-Juvenil, Livro Didático e Participação da Comunidade na Formação de Leitores. São Paulo: Faculdades Teresa Martin, 1995. p. 388-390.

. Livro didático entre textos e imagens. In: BITTENCOURT, C.M.F. (org). O saber histórico na sala de aula. São Paulo: Contexto, 1997.

BONNICl, Peter. Visual language: the hidden medium of communication. CransPrès-Celigny (Switzerland): RotoVision, 1999.

BRAGA, Marcos da Costa. Organização profissional dos designers no Brasil: APDINS-RJ, a luta pela hegemonia no campo profissional. Tese de doutorado. Niterói: Universidade Federal Fluminense, 2005.

CAMARGO, Mário de (org.). Gráfica. Arte e Indústria no Brasil: 180 anos de história. São Paulo: Bandeirantes/EDUSC, 2003.

CARDOSO, Rafael. Uma introdução à história do design. 2 ed. São Paulo: Edgard Blücher, 2004.

O design brasileiro antes do design: aspectos da história gráfica, 18701960. São Paulo: Cosac Naify, 2005.

CHOPPIN, Alain. História dos livros e das edições didáticas: sobre o estado da arte. In: Educação e Pesquisa, v. 30, n. 3. São Paulo, set/dez 2004. p. 549-566.

DE FUSCO, Renato. Projeto, produção, Venda, Consumo. In: Design em aberto. [Lisboa]: Centro Português de Design, 1993.

DONDIS, Donis A. Sintaxe da linguagem visual. Tradução de Jefferson Luís Camargo. São Paulo: Martins Fontes, 1997.

DVORECKI, Silvio. Em busca do traço perdido. São Paulo: Scipione-Edusp, 1998.

EDITORA ABRIL. A revista no Brasil. São Paulo: Abril, 2000.

EDWARDS, Betty. Desenhando com o lado direito do cérebro. Tradução de Roberto Raposo. 11. ed. Rio de Janeiro: Ediouro, sd.

ESCOREL, Ana Luisa. Brochura brasileira: objeto sem projeto. Rio de Janeiro: J. Olympio/INL, 1974.

FERNANDES, Antonia Terra de Calazans. Livros didáticos em dimensões materiais 
e simbólicas. In: Educação e Pesquisa, v. 30, n. 3. São Paulo, set/dez 2004. p. 549-566.

FORTY, Adrian. Objetos de desejo: design e sociedade desde 1750. Tradução de Pedro Maia Soares. São Paulo: Cosac Naify, 2007.

FRIEDEL, Friedrich; OTT, Nicolaus; STEIN, Bernard. Typography: an encyclopedic survey of type design and techniques throughout history. New York: Black Dog \& Leventhal, 1998.

GOLDCHMIT, Sara Miriam. Odiléa Setti Toscano: do desenho ao design. Dissertação de mestrado. São Paulo: FAUSP, 2008.

GOTTSCHALL, Edward M. Typographic Communications Today. New York / Cambridge, Massachussets, London: International Typeface Corporation / The MIT Press, 1989.

HALLEWELL, Laurence. O livro no Brasil: sua história. 2. ed São Paulo: Editora da Universidade de São Paulo, 2007. .

HELLER, Steven. Linguagens do design: compreendendo o design gráfico. Tradução de Juliana Saad. São Paulo: Rosari, 2007.

HENDEL, Richard. O design do livro. Tradução de Geraldo Gerson de Souza e Lúcio Manfredi. São Paulo: Ateliê Editorial, 2003.

HOBSBAWN, Eric. Era dos extremos: O breve século XX: 1915-1991. Tradução de Marcos Santarrita. São Paulo: Companhia das Letras, 1996.

HOLLIS, Richard. Design gráfico: Uma história concisa. Tradução de Carlos Daudt. São Paulo: Martins Fontes, 2005.

HOMEM DE MELO, Chico. O design gráfico brasileiro: anos 60. São Paulo: Cosac Naify, 2006.

HOMENS E LIVROS: edição comemorativa dos 40 anos do IBEP e dos 80 anos da Companhia Editora Nacional. São Paulo: IBEP/Nacional, 2005.

KRESS, Gunther; LEEUWEN, Theo van. Reading images: The grammar of visual design. 2. ed. London, New York: Routledge, 2008.

KUCINSKI, Bernardo. Jornalistas e revolucionários: nos tempos da imprensa alternativa. São Paulo: Edusp, 2003.

LAJOLO, Marisa \& ZILBERMAN, Regina. A formação da leitura no Brasil. 3. ed. São Paulo: Ática, 1999.

LEAL, M. Angela. Desenvolvimento, desigualdade econômica e educação. In: LEVIN, Henry M. et alli. Educação e desigualdade no Brasil. Petrópolis: Vozes, 1984.

LÉVY, Pierre. As tecnologias da inteligência. Tradução de Carlo Irineu da Costa. Rio de Janeiro: Editora 34, 1993.

LINS, Osman. Do ideal e da glória: problemas inculturais brasileiros. São Paulo: Summus, 1997. 
MAMMI, Lorenzo. Concreta '56: a raiz da forma (uma reconstrução da I Exposição Nacional de Arte Concreta). In: MUSEU DE ARTE MODERNA DE SÃO PAULO. Concreta ‘56: a raiz da forma. (Catálogo da exposição de mesmo nome). São Paulo, MAM, 2006.

MAYER, Richard E. Multimedia Learning. Second edition. New York: Cambridge University Press, 2009.

MEGGS. Philip B. História do Design Gráfico. Tradução de Cid Knipel. São Paulo: Cosac Naify, 2009. Trad. Cid Knipel.

MORIN, Edgar. Cultura de massas no século XX. v. 1: Neurose. 9. ed. Tradução de Maura Ribeiro Sardinha. Rio de Janeiro: Forense Universitária, 2009a.

Cultura de massas no século XX. v. 2: Necrose. 3. ed. Tradução de Agenor Soares Santos. Rio de Janeiro: Forense Universitária, 2009b.

MUNAKATA, Kazumi. 1997. Produzindo livros didáticos e paradidáticos. Tese de doutorado. São Paulo: Pontifícia Universidade Católica.

NOVAES, Adauto (org.). Anos 70: ainda sob a tempestade. Rio de Janeiro: Senac/ Aeroplano, 2005.

OLIVEIRA, João Batista Araújo et al. A política do livro didático. São Paulo: Summus; Campinas: Editora da Unicamp, 1984.

OLIVEIRA, Sandra Ramalho e. Imagem também se lê. São Paulo: Rosari, 2006.

PAIXÃO, Fernando (org.). Momentos do livro no Brasil. São Paulo: Ática, 1995.

RAZZINI, Márcia de Paula Gregório. O espelho da nação: a Antologia Nacional e o ensino de Português e de Literatura (1838-1971). Tese de doutorado. Campinas: Universidade Estadual de Campinas, Instituto de Estudos de Linguagem, 2000.

A Antologia Nacional e a ascensão do Português no currículo da escola

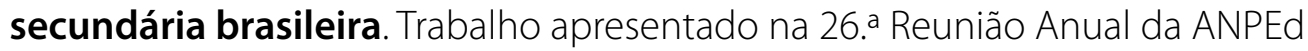
- Associação Nacional de Pós-Graduação e Pesquisa em Educação, 2003.

ROMANELLI, Otaiza de O. História da educação no Brasil, 1930-1973. 27. ed. Petrópolis: Vozes, 2002.

ROSE, Gillian. Visual Methodologies: An Introduction to the Interpretation of Visual Materials. 2 ed. London: Sage, 2007.

ROSSI FILHO, Sérgio. Graphos: glossário de termos técnicos em comunicação gráfica. São Paulo: Editorial Cone Sul, 2001.

SANTAELLA, Lucia; NÖTH, Winfried. Imagem: cognição, semiótica, mídia. São Paulo: lluminuras, 1992. 2. ed.

SATUÉ, Enric. Aldo Manuzio: Editor. Tipógrafo. Livreiro. Tradução de Cláudio Giordano. Cotia: Ateliê Editorial, 2004.

SNYDER, Gertrud; PECKOLIC, Alan. Herb Lubalin: art director, graphic designer and typographer. New York: American Showcase, 1985. 
STOLARSKI, André. Projeto Concreto; O design brasileiro na órbita da I Exposição Nacional de Arte Concreta: 1948-1966. In: MUSEU DE ARTE MODERNA DE SÃO PAULO. Concreta '56: a raiz da forma. (Catálogo da exposição de mesmo nome). São Paulo, MAM, 2006a.

STOLARSKI, André. A identidade visual toma corpo. In: HOMEM DE MELO, Chico (org.). O design gráfico brasileiro: anos 60. São Paulo: Cosac Naify, $2006 \mathrm{~b}$.

TAKAHASHI, Jiro. Entrevista para o Boletim Ática/Áticanet. Disponível em: <http:// www.atica.com.br/entrevistas/?=32>. Acesso: 6 set. 2009.

THE PUSH PIN STUDIOS. The Push Pin Style. Palo Alto: Communication Arts Magazine, 1970.

VOLLI, Ugo. Manual de semiótica. São Paulo: Loyola, 2007. Tradução de Silva Debetto C. Reis.

WOLLNER, Alexandre. A emergência do Design Visual no Brasil. In: AMARAL, Aracy (org.). Arte Construtiva no Brasil. Coleção Adolpho Leirner. São Paulo: DBA, 1998.

\section{Depoimentos}

CAFIERO, Mário: depoimento gravado [12 set. 2009]. 99 min. Concedido ao autor. CAMPOS, Carmem Lúcia: depoimento escrito [7 jan. 2008]. Concedido ao autor. GUIZZO, João: depoimento escrito [5 jan. 2008]. Concedido ao autor.

NORMANHA, Ary Almeida: depoimento gravado [7 jan. 2008]. 182 min. Concedido ao autor.

SILVA, Irami Bezerra da: depoimento gravado [29 ago 2009]. 72 min. Concedido ao autor. 


\section{Fontes das imagens reproduzidas}

\section{Parte I}

A maioria das imagens das capas de livros foram fotografadas do acervo da Biblioteca do Livro Didático da Faculdade de Educação da Universidade de São Paulo. As demais imagens têm as seguintes origens:

p. 31: Acervo pessoal.

p. 40: Centro de Investigación Manes - Manuales Escolares: www.uned.es/manesvirtual

p. 41: Acervo Marcello Araújo.

p. 61: Fig. 1, 3, 4: CARDOSO, 2005 (ver Bibliografia); Fig. 2: Wikipedia; Fig. 5, 6, 9, 10:

CAMARGO, 2003.; Fig. 7: PAIXÃO, 1995.

p. 62: Acervo Companhia Editora Nacional.

p. 63: Acervo Chico Homem de Melo.

p. 72: Fig. 10: Acervo Sara Goldchmit.

p. 75: Fig. 1 a 6: FRIEDEL; OTT; STEIN, 1998; Fig. 7: GOTTSCHALL, 1989; Fig. 8, 12 a 15:

STOLARSKI, 2006a; Fig. 10 e 11:WOLLNER, 1998.

p. 76: Acervo Nilson José Machado.

p. 77: SNYDER; PECKOLIC, 1985.

p. 78: Acervo pessoal.

\section{Parte II}

A maioria das imagens das capas de livros foram digitalizadas do acervo da Editora Ática. As demais imagens têm as seguintes origens:

p. 84: Fig. 1 e 2: Acervo Luiz Tonolli.

p. 85: Fig. 1: Acervo Luiz Tonolli.

p. 87: Fig. 3: PAIXÃO, 1995.

p. 90 e 91: Acervo Sara Goldchmit.

p. 92: Acervo Mário Cafiero.

p. 93: Acervo pessoal.

p. 95: Fig 1: GOTTSCHALL, 1989; Fig. 2, 3, 5, 11, 12, 13 e 15: MEGGS, 2009; Fig. 6 a 10:

SNYDER; PECKOLIC, 1985; Fig. 14: THE PUSH PIN STUDIOS, 1970.

p. 97: Fig. 2: Acervo Mario Cafiero. Fig. 3: PAIXÃO, 1995.

p. 98: Acervo Mário Cafiero.

p. 99: Fig. 1: Acervo pessoal; Fig. 2 e 3: Acervo Mário Cafiero.

p. 100: Fig. 1 e 3: PAIXÃO, 2005; Fig. 2: Acervo pessoal.

p. 107: Acervo pessoal.

p. 117: volume de 7. a série: Acervo Francisco Moura.

p. 121 e 123: Acervo Amadeu Marques.

p. 130: Acervo Ary Normanha (provas de prelo).

p. 151: Book 4: Acervo Amadeu Marques.

p. 166: Fig 1 a 4: Acervo Platão Saviolli. 